Universidade de São Paulo

Faculdade de Filosofia, Letras e Ciências Humanas

Departamento de História

Programa de Pós-GraduaÇão em História Econômica

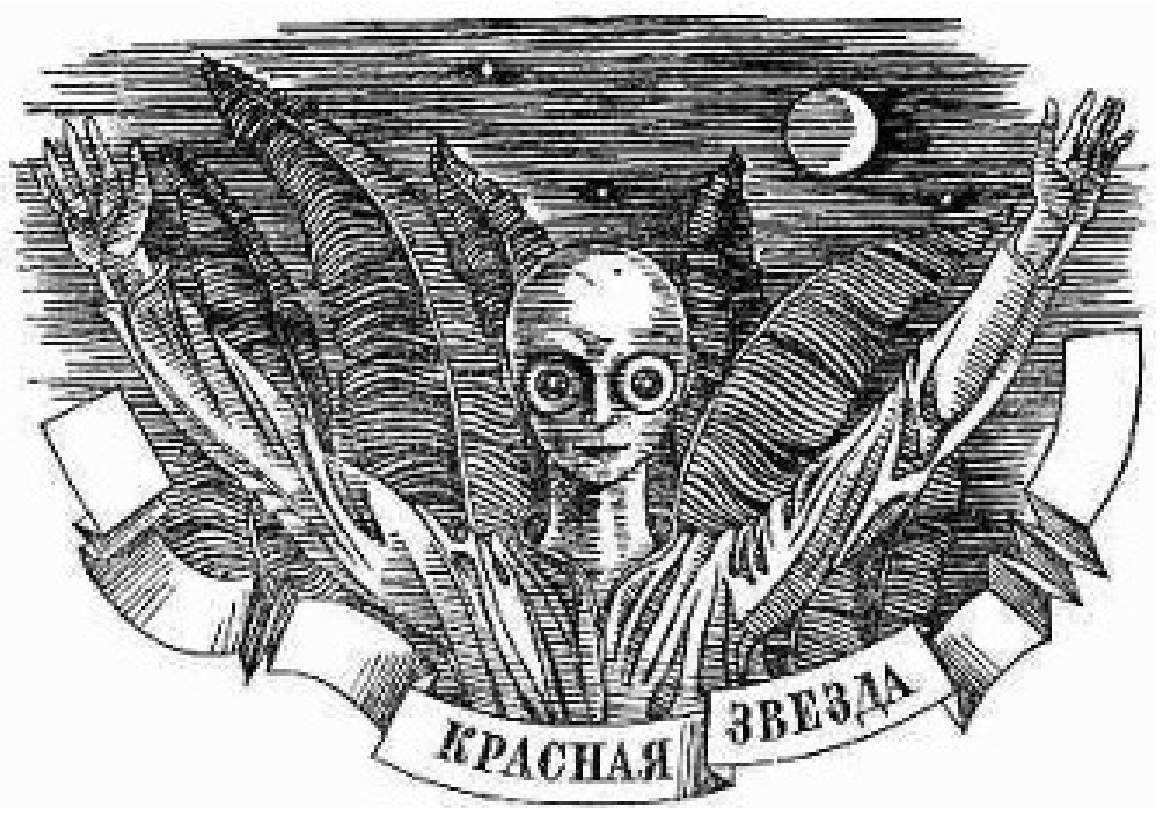

"KraSNAYA ZvEZDA"

Uma leitura político-econômica

da primeira utopia literária soviética

Pedro Ramos de Toledo

São Paulo

2019

Versão Corrigida 
Universidade de São Paulo

Faculdade de Filosofia, Letras e Ciências Humanas

Departamento de História

Programa de Pós-GraduaÇão em História Econômica

\title{
"KRASNAYA ZvEZDA"
}

\author{
Uma leitura político-econômica
}

da primeira utopia literária soviética

\section{Pedro Ramos de Toledo}

\begin{abstract}
Dissertação apresentada ao Programa de PósGraduação em História Econômica do Departamento de História da Faculdade de Filosofia, Letras e Ciências Humanas da Universidade de São Paulo, para obtenção do título de Mestre em História.
\end{abstract}

Orientador: Prof. Dr. Luiz Bernardo Murtinho Pericás

São Paulo

2019

Versão Corrigida 
Autorizo a reprodução e divulgação total ou parcial deste trabalho, por qualquer meio convencional ou eletrônico, para fins de estudo e pesquisa, desde que citada a fonte.

Catalogação na Publicação

Serviço de Biblioteca e Documentação

Faculdade de Filosofia, Letras e Ciências Humanas da Universidade de São Paulo

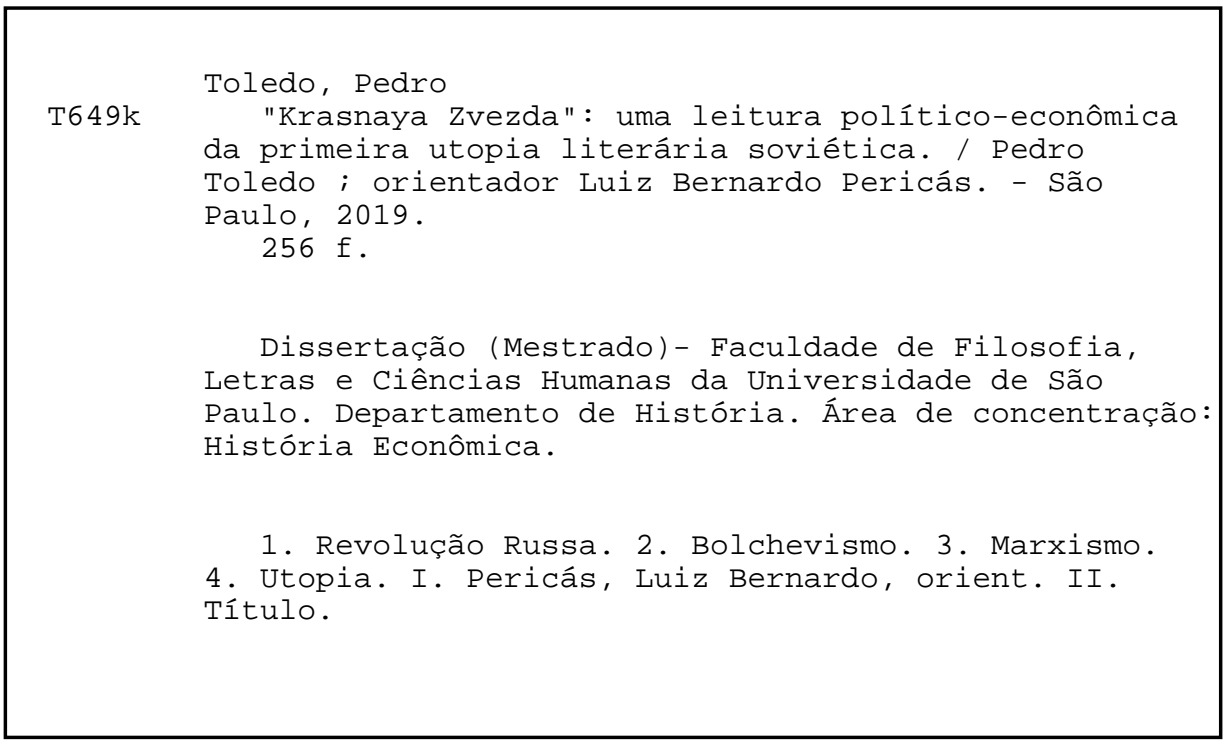




\section{ENTREGA DO EXEMPLAR CORRIGIDO DA DISSERTAÇÃO/TESE}

\section{Termo de Ciência e Concordância do (a) orientador (a)}

Nome do (a) aluno (a): Pedro Ramos de Toledo

Data da defesa: __13_/__12_/_2019__

Nome do Prof. (a) orientador (a): Prof. Dr. Luiz Bernardo Murtinho Pericás_

Nos termos da legislação vigente, declaro ESTAR CIENTE do conteúdo deste EXEMPLAR CORRIGIDO elaborado em atenção às sugestões dos membros da comissão Julgadora na sessão de defesa do trabalho, manifestando-me plenamente favorável ao seu encaminhamento e publicação no Portal Digital de Teses da USP.

São Paulo 13 02 2020

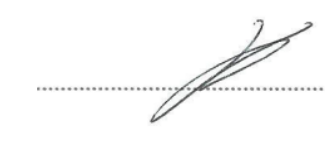




\section{Créditos das imagens}

Capa: "Marciano de Aleksandr Bogdánov", ilustração de G. Memtchenko, 1979.

Introdução: Capa da $1^{\mathrm{a}}$ edição de "Krasnaya Zvezda", autor desconhecido, 1908.

Capítulo 2: "Bogdanov" (circa 1904). Fotografia extraída do arquivo de Simona Poustilnik, publicada pela primeira vez no Nezavisimaya gazeta, novembro de 1904.

Capítulo 3: "Enno e Leonid visitam o museu", 1ª edição de "Krasnaya Zvezda", autor desconhecido, 1908.

Capítulo 4: "Lenin como convidado de M. Gorkii joga xadrez com Aleksandr Bogdánov", fotografia de Yo. A. Zheliabuzhskii, Capri, Itália, 1908.

Conclusão: "Rabotniki", ilustração de Vladimir Lebedev, 1923. 
Aos meus pais, pelo amor e paciência incondicionais, A minha filha Julia, luz da minha vida e razão do meu ser, A minha amada companheira Lívia, amor da minha vida. Não imagino meu mundo sem vocês. 


\section{Agradecimentos}

Existe uma fantasia bastante difundida acerca do ofício do pesquisador. Nessa fantasia, o pesquisador é geralmente representado como um ser distanciado, dedicado à solitária tarefa de produzir conhecimento, de trazer luz sobre aquilo que não é conhecido. Essa visão é tão romântica quanto falsa. Se um texto carrega a marca autoral de seu autor, também é certo que este é um trabalho dotado de sociabilidade, em que diversas pessoas deixam suas marcas, mesmo que invisíveis, em sua confecção. Tal produção é tributária, como expressou Walter Benjamim de forma tão bela, à "corveia anônima dos contemporâneos". Este é o momento em que dedicamos algumas palavras de agradecimento a todos aqueles que contribuíram muito mais do que estas poucas palavras deixam transparecer.

Em primeiro lugar quero agradecer à minha família. Aos meus pais, Ana Maria e Rubens Eduardo, pelo profundo amor e dedicação que sempre dedicaram a mim e aos meus irmãos e pelo exemplo de humanidade que nos proporcionaram; à Lívia, esposa, companheira e amor da minha vida, pelo apoio e carinho incontáveis e sem os quais este trabalho não seria possível; à minha amada "filota" Bijuca, linda e talentosa, cuja presença abençoa os meus dias; aos meus irmãos Júlio e Caio, pelo companheirismo e exemplo de integridade; aos meus sobrinhos Dudu e Flora, com seus sorrisos largos e risadas gostosas; à minha tia $\mathrm{Lu}$, pessoa de uma alma gigante, pelos cafés, bolos e companhia; aos meus sogros Iuri e Kengo e à minha cunhada Luciana, pelo carinho e apoio.

Ao meu orientador, Prof. Dr. Luiz Bernardo M. Pericás, por ter me acompanhado nessa jornada, sempre paciente e atento.

Aos Profs. Drs. Ricardo Musse e José Antonio Vasconcellos, membros 
da banca de qualificação desta Dissertação, pelos preciosos conselhos e considerações que em muito contribuíram para a elaboração deste trabalho.

Aos professores Ricardo Musse, José Antonio Vasconcellos, Marcos Tadeu del Roio, Fabio Mascaros Sobrinho, Uiran Gebara da Silva e Francisco Assis de Queiroz por honrarem este trabalho com seu aceite para a participação da banca de defesa.

Ao meu amigo e camarada Uiran, pela generosidade de seus conselhos, pela leitura cuidadosa e palavras de apoio. Você vale seu peso em ouro, meu caro.

Ao meu comparsa Tiago Atorre, visto pela última vez cavando buracos na terra dos cangurus. Você faz uma falta danada, magriça. Esse mundo não te merece.

Agradeço também às minhas queridas amigas Carine, Sofia e Nádia, e ao querido amigo Rangel, que acompanharam e participaram do desenvolver deste trabalho em nossas reuniões semanais. Para a Carine, um docinho; para a Sofíssima, um cuscuz; para o Rangel, lasanha de funghi secchi; e para a Nádia, mulher guerreira, alguma iguaria sem carne.

Deixo meu agradecimento aos amigos que fiz no decorrer da Pós-Graduação e em especial à Raíssa e ao Robson, casal de ouro com o qual consumi muitos litros de café e com quem tive excelentes conversas. Lembrem-se: Star Trek $>>>$ Star Wars.

Fica registrado meu abraço especial ao pessoal do LEMARX: Fernando, Francisco, Anderson, Ilan, Anoush, Thomas e Mateus que, sob a coordenação do Prof. Musse, me proporcionaram um ambiente rico em debates e reflexões.

À minha querida professora de russo Aninha, que tem me aguentado nos últimos 15 meses, agradeço pelas aulas e pela enorme ajuda na transliteração e no cotejamento da tradução da obra aqui analisada, "Krasnaya Zvezda". O comunismo triunfará, guerreirinha.

E, não menos importante, um abraço de sequoia a todos os meus amigos que acompanham minhas presepadas há mais de duas décadas: Ao Tiago e à Veruska, os melhores móveis da minha casa; à Camila, tão brilhante quanto generosa; ao Berns e à Claudinha, pelas pessoas lindas que são; ao Hans e à Carol, pela maravilhosa companhia; ao Nogs, Fi e Mau, Paulinho e 
André, exemplos de que alguns afetos não se apagam com tempo; ao Rodolfo e à Alana, pelas noites cheias de dados e amizades; à Lana, por cuidar dos meus gatos como se fossem seus (mas não são, viu?); A Lucas, pelas feijucas incríveis; ao Raiji, alma iluminada e única lembrança boa que tenho do quartel; ao Marcosa, o cara mais porreta de Gotham City; ao Luiz, artista brilhante e pai do icônico Rato Robson; ao Macé, cuja generosidade só é menor que sua coleção de jogos de tabuleiros.

À CNPq, agradeço pela bolsa concedida. Aos secretários do Programa de Pós-Graduação, pelo relevante serviço que prestam para a pesquisa nacional.

E a todos os marcianos que, náufragos nestes tempos sombrios, não perdem de vista um novo mundo possível. 


\section{Resumo}

Dentre os diversos pensadores russos que compunham a velha guarda bolchevique na década de 1900, Aleksandr Aleksandrovich Malinovskii (Bogdánov) é talvez a personagem menos estudada pela historiografia do período prérevolucionário russo, embora tenha desempenhado um papel crucial nos primeiros anos de formação do Partido Operário Social Democrata Russo (POSDR) e sua obra tenha tido grande importância no campo da cultura nas primeiras décadas do século XX. Apenas recentemente é que a obra de Bogdánov passou a receber atenção de estudiosos no Ocidente. Dentre seus trabalhos publicados até o final dos anos 1920, posteriormente censurados sob o regime estalinista, destaca-se "Krasnaya Zvezda" (Estrela Vermelha), publicada em 1908 em meio a um importante debate tático e filosófico com Lenin. Nessa obra de ficção científica, Bogdánov, através dos olhos de um jovem bolchevique, apresenta a seus leitores uma utopia comunista em Marte, resultante de uma revolução levada a cabo trezentos anos antes dos eventos de 1905. Esta pesquisa analisa a obra "Estrela Vermelha" de Aleksandr Bogdánov, tendo como pano de fundo os diversos debates formativos da Intelligentsia social-democrata russa e, de forma mais específica, a controvérsia estabelecida entre Lenin e Bogdánov sobre os caminhos políticos e econômicos a serem trilhados para a construção do socialismo. Assim, este trabalho contribui para mais bem compreendermos as imbricações entre os debates existentes no seio da Intelligentsia revolucionária e sua práxis delimitada pelas especificidades do cenário histórico russo a partir das ideias políticas e econômicas de Bogdánov, expressas como exercício imagético em sua utopia literária. 


\section{Abstract}

Among the many Russian thinkers that were part of the first generation of Bolsheviks in the 1910s, Aleksandr Aleksandrovish Malinovskii (Bogdanov) is perhaps the least studied by the historiography of the Russian pre-revolutionary period, in spite of his crucial role in the formative years of the Russian Social Democratic Labour Party (RSDLP) and the importance of his works in the field of culture in the first decades of the 20th century. Only recently has Bogdanov's work been studied by Western scholars. Among his works published before the late 1920s, later censored by the Stalinist regime, is Krasnaya Zvezda ("Red Star"), published in 1908 in the midst of an important tactical and philosophical debate with Lenin. In this science fiction novel, Bogdanov, through the eyes of a young Bolshevik, presents his readers a communist utopia in Mars, that took place 300 years before the events of 1905. This research analyzes the work "Red Star" by Aleksander Bogdanov, having as its background the many formative debates among the Russian social democratic Intelligentsia and, more especifically, the controversy between Lenin and Bogdanov on the sociopolitical paths towards socialism. Thus this research contributes to better understanding the debates among the revolutionary Intelligentsia and its praxis, delimited by specificities of the Russian historical scenario, on the basis of Bogdanov's political and economical ideias put forth as an imagetic exercise in his literary utopia. 


\section{Sumário}

Resumo viii

Abstract ix

1 Introdução 1

1.1 Aleksandr Bogdánov: um intelectual entre dois mundos . . . . 6

1.2 Utopia, radicalidade e ficção científica . . . . . . . . . . . . . . 11

1.3 Fundamentação teórica e objetivos . . . . . . . . . . . . . . . 18

1.4 Método expositivo . . . . . . . . . . . . . . . . . 23

2 Empiriomonismo $\quad 26$

2.1 O debate entre Bogdánov e Berdiaev . . . . . . . . . . . . . . 29

2.2 A Filosofia da Vivência . . . . . . . . . . . . . . . . . . . . 34

2.2.1 Introdução da obra . . . . . . . . . . . . . . . 36

2.2.2 O que é materialismo? . . . . . . . . . . . 46

2.2.3 Empiriomonismo e a Ciência do Futuro . . . . . . . . . 51

3 Narodistas, marxistas e marcianos $\quad 62$

3.1 O fim da servidão e a desestruturação da obshchina . . . . . . 66

3.2 A crítica narodnik . . . . . . . . . . . . . . . . . . 70

3.3 Plekhánov e a crítica marxista ao narodnitchestvo . . . . . . . 75

3.4 Lenin e os narodniks . . . . . . . . . . . . . . . . . . . . . . . 82

3.5 A questão agrária em "Estrela Vermelha" . . . . . . . . . . . 94

3.6 Cidade-uso, cidade-produto . . . . . . . . . . . . . . 103

3.6.1 A arte proletária e a tradição radical . . . . . . . . . . 112 
4 Entre o homem e a máquina $\quad 121$

4.1 Materialismo dialético como epistemologia da ciência . . . . . 124

4.2 Empiriocriticismo ou Empiriomonismo? . . . . . . . . . . . . . 140

4.3 Entre a cultura e a revolução . . . . . . . . . . . . . . . . . 145

4.4 Sistemas, funções e elementos . . . . . . . . . . . . . . . . . 152

4.5 Nauchnaya Organizatsia Truda-NOT . . . . . . . . . . 157

4.6 Alexei Gastev e o Proletkult . . . . . . . . . . . . . . . . . 163

4.7 Produção e Estado em "Estrela Vermelha" . . . . . . . . . . . 170

4.8 Socialismo da ciência . . . . . . . . . . . . . . . . . . . . . 189

5 Considerações Finais $\quad 222$

Referências 233 
1

\section{Introdução}

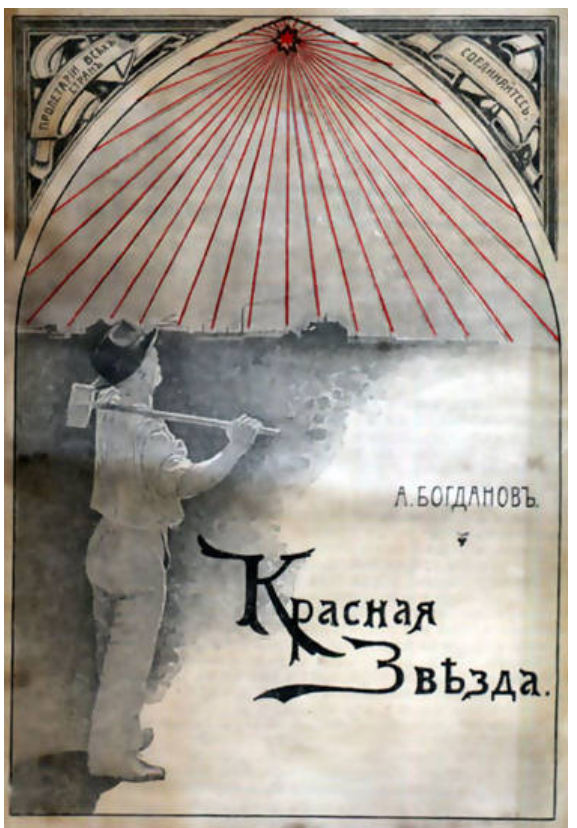

"Revolução é mais do que mera tomada de poder, seguida da insurreição das massas. É um evento cataclísmico, alimentado por prescrições ideológicas que apontam para uma sociedade mais perfeita, que traz em si profundas transformações nas esferas política, cultural e econômica." 
O que é uma revolução?

A resposta para essa questão traz consigo uma longa tradição histórica, tão diversa quanto o próprio caráter polissêmico do termo. Seu uso abarca uma ampla gama de fenômenos históricos, distribuídos entre diversos campos da sociabilidade. Revoluções podem ser políticas, sociais, científicas, artísticas, produtivas, comportamentais. Essa problemática se intensifica ao nos apercebermos o quão estanques são tais categorias, uma vez que não há processo revolucionário que não reverbere nas mais diversas esferas da experiência humana. Não é possível pensarmos, a título de exemplo, a revolução industrial como mero desenvolvimento da máquina a vapor. O surgimento da maquinofatura reorganiza toda a esfera da produção; intensifica a divisão social do trabalho; eleva a produtividade em magnitude inédita; redefine a própria noção de espaço e tempo ao reduzir as distâncias, reconfigurar o papel do espaço urbano e acelerar o circuito de produção das mercadorias; cria uma nova classe social a partir dos despossuídos da terra. Cria tanto as condições iniciais de um capitalismo universal como exacerba as contradições inerentes a tal sistema. Acrescente-se a isso a dificuldade mesma em compreender as revoluções como processos com limites claramente definidos. Em sua introdução a "Era das Revoluções", Hobsbawm (2012:6) denomina de "dupla revolução" um amplo movimento de coadunação entre as revoluções industrial inglesa e a política francesa enquanto epifenômenos do triunfo da classe burguesa e fundamentos de uma ordem capitalista global.

A despeito das preciosas contribuições dos socialistas franceses para uma teoria da revolução, Marx foi pioneiro em compreender o caráter multidimensional desse conceito. Edward Carr demonstra que Marx, a partir de uma ampla generalização histórica, somente possível através da aplicação de seu método histórico-materialista, compreendeu já no "O Manifesto Comunista" a profunda imbricação entre processos histórico-sociais que se encontram muitas vezes submersos no ato inconsciente das classes em disputa, mas que despertam no momento em que tais lutas são postas à luz da história e expressam as contradições dialéticas na forma da revolução (Carr, 1964 : 19). Para Marx, através da compreensão dessas contradições seria possível atuar por uma transformação radical das relações sociais e produtivas, libertando a 
humanidade do jugo da necessidade. A revolução traz em si, ao implodir as relações produtivas existentes, essa possibilidade radical. No centro da critique marxiana à sociedade capitalista burguesa encontra-se o desenvolvimento, já em seus trabalhos iniciais, de uma teoria da práxis que transcendesse a oposição entre teoria e prática, entre pensamento e ação, e que respondesse monisticamente a um movimento de transformação cujas partes encontrassem dialeticamente integradas - uma teoria revolucionária (Löwy, 2003:11). A despeito de abordagens que buscam clivar a obra marxiana temporalmente, é possível acompanhar o desenvolvimento dessa ideia por toda a sua obra. Marx demonstra a força de sua análise dialética ao realizar a crítica às jornadas de fevereiro de 1848 a partir de uma diferenciação conceitual entre as revoluções políticas do século XIX, marcadas pelos símbolos e referências do passado, e a revolução social, que pode nutrir-se tão somente do novo e cujo olhar encontra-se fixo no futuro:

"Não é no passado, mas unicamente no futuro, que a revolução social do século XIX pode colher sua poesia. Ela não pode começar a dedicarse a si mesma antes de ter despido toda a superstição que a prende ao passado." (Marx, 2011b:28)

Essa passagem nos permite compreender uma característica fundamental tanto do pensamento marxiano quanto da própria tradição marxista: uma resistência resoluta em predizer futuros, seja enquanto realização da práxis, seja enquanto exercício imagético. Diferentemente do que apontam muitos de seus detratores, excetuando algumas passagens da "Crítica do programa de Gotha", Marx evitou realizar predições. A razão para isso se encontra na própria natureza de seu método: o materialismo histórico. Através dele, Marx transformou diversos campos do saber ao ancorar a análise da totalidade social a partir das relações de produção historicamente determinadas. É a partir da análise de formas sociais acabadas que se torna possível identificar vestígios de formas sociais precedentes. Assim o modelo marxiano encontra na especificidade histórica do presente o seu limite. Marx não pode predizer o futuro pois este somente existe em potencialidade. Parafraseando a famosa analogia de Marx exposta nos "Grundisse", não é possível prever na fisiologia do macaco a forma superior do homem. Da mesma forma, não é possível 
descrever uma sociedade futura de homens desalienados a partir dos limites históricos impostos pela alienação do presente. O futuro encontra-se em aberto e será papel das gerações futuras a sua construção. A teoria de Marx não trata do futuro a não ser como possibilidade através da transformação do presente, uma transformação que deriva da análise das contradições presentes na totalidade social historicamente dada aos homens.

A revolução tem assim um sentido cataclísmico, em que as relações de produção e o universo simbólico de representações que emergem a partir delas são esgarçadas ao ponto da ruptura. Esse é um ato violento, mas também carregado de energia utópica: o tempo que se abre é imponderável e todas as possibilidades encontram-se suspensas. Passado e futuro condensam-se em uma singularidade cuja determinação deriva da direção em que os sujeitos revolucionários olham para buscar suas referências. Marx anteviu esse processo ao tratar as formas da revolução possíveis a partir desse direcionamento. Em "Minha Vida", Trotsky descreve esse estado de singularidade com maestria:

"Na superfície, não parecia muito imponente: homens vagavam cansados, famintos e sujos, com olhos inflamados e barbas por fazer. E posteriormente nenhum deles lembrava muito sobre os dias e horas mais críticos." (Trotski, 1978:283)

Utopia como impulso; ruptura como processo; tempos colapsados no presente. Walter Benjamin percebeu essa dialética utópica presente no olhar de Marx sobre a revolução social e a expressou em suas "Teses de História" ao descrever o anjo da história que, preso pela tempestade do progresso, é arremessado em direção ao futuro enquanto as ruínas do passado prendem sua atenção. O anjo busca resgatar os mortos que se acumulam, porém é impedido pelos ventos que partem do paraíso (Benjamin, 1987:226). Talvez pareçam contraditórias as posições de Benjamim e Marx acerca do resgaste dos mortos. No entanto essa aparência é desfeita ao lembrarmos que ambos eram pensadores dialéticos. Marx cita o livro bíblico de Lucas ao exortar que "a revolução do século XIX precisa deixar que os mortos enterrem seus mortos" (Marx, 2011b:29). Benjamin também se utiliza de uma figuração cristã para demonstrar a História presa entre o passado e o futuro. Marx 
pede que o anjo se vire na outra direção. É sob o "livre céu da história" (Benjamin, $1987: 230$ ) - a revolução social - que os mortos serão redimidos.

A busca por esse futuro transformador é um traço definidor da intelectualidade radical russa, cuja história não pode ser adequadamente descrita sem tomar em conta esse elemento. Decerto que há outros fatores envolvidos em sua constituição, assim como houve elementos revolucionários em outras tradições intelectuais. Porém a radicalidade russa encontra sua especificidade no fato de que a revolução social sempre se apresentou como o único caminho de transformação. Por um lado um radicalismo de caráter social, um vez que o Estado russo autocrático acabou por fazer gravitar em torno de si questões caras à intelectualidade europeia da época, como a própria questão nacional; por outro, a autoconsciência enquanto grupo social especial, reconhecimento que deriva da virtual inexistência de uma classe média constituída (Hobsbawm, 2012 :177). Foi a partir dos anos 1860 que esse grupo social - tão diverso intelectualmente quanto coeso em sua rejeição ao regime autocrático dos czares - passou a se intitular "Intelligentsia", termo que permanece até hoje como sinônimo de uma intelectualidade socialmente militante.

Este trabalho objetiva contextualizar o desenvolvimento da Intelligentsia entre a passagem dos séculos XIX e XX a partir da leitura da obra "Estrela Vermelha", um romance utópico de Ficção Científica (FC) escrito por Aleksandr Bogdánov, um dos mais importantes e originais membros da Intelligentsia que viveram os primórdios do Partido Operário Social-Democrata Russo (POSDR) e cuja influência se estendeu até os anos formativos do Estado Soviético. Através de um recorte que privilegia aspectos políticos e econômicos de seu pensamento, buscamos apresentar suas raízes, enterradas no solo fértil da tradição radical russa, bem como sua posterior influência. Essa também é uma tentativa de apresentar um intelectual sistemático e sofisticado, cuja obra - após décadas de esquecimento - vem aos poucos sendo recuperada. Seguiremos com uma concisa apresentação, de forma a introduzir Bogdánov ao leitor. 


\subsection{Aleksandr Bogdánov: um intelectual entre dois mundos}

Aleksandr Aleksandrovich Malinovskii (Bogdánov) é talvez a personagem mais suprimida e negligenciada pela historiografia soviética. Essa condição causa estranheza ao se aperceber do papel crucial que exerceu nos primeiros anos de formação do Partido Operário Social Democrata Russo (POSDR), bem como da importância de sua obra dentro das mais diversas esferas de ação cultural e política nas duas primeiras décadas do século XX. Sua obra foi publicada de forma mais ou menos contínua até o final dos anos 1920, desaparecendo com o endurecimento da censura estalinista e controle do Estado Soviético sobre a produção historiográfica referente ao período anterior à ascensão de Stálin (Gloveli \& Biggart, 1991:31). Mantida no limbo por um longo período, foi apenas nas últimas décadas que a obra de Bogdánov passou a receber atenção de estudiosos no Ocidente (Sochor, 1988:9). No Brasil, o nome de Bogdánov é praticamente desconhecido e, de um modo geral, não há estudos voltados para sua obra. Essa é uma lacuna na produção historiográfica brasileira para cujo preenchimento este trabalho pretende contribuir.

Bogdánov tem sido visto, tradicionalmente, como um intelectual polivalente, que atuou em diversos campos de conhecimento: ativista político, economista, escritor, filósofo, cientista, crítico cultural, pedagogo e polemista. Os debates acerca de sua obra parecem localizar-se em polos extremos: por um lado, autores que veem Bogdánov como: "[...] em parte um gênio, em parte pioneiro, em parte um teórico socialista sério e, no todo, um importante, interessante e original pensador russo" (Jensen, 1982:1); por outro: “[...] um pensador confuso, cuja filosofia se baseava em dois princípios irremediavelmente inconciliáveis: antiautoritarismo e coletivismo" (Kelly, 1990 :312). Tal polarização evidencia dois problemas principais quando se depara com a produção bibliográfica referente ao autor: em primeiro lugar, a visão unidimensional que impera sobre sua obra; em segundo, a presença de um debate político subjacente aos campos de estudo sobre o período formativo da Rússia Soviética, que conforma e enquadra o olhar dos pesquisadores em relação ao 
seu objeto.

Esses problemas derivam de peculiaridades existentes tanto no pensamento bognadoviano quanto em sua trajetória como ativista político. A heterogeneidade de sua produção dificulta uma análise sistêmica de sua obra, uma vez que Bogdánov se dedicou a questões diversas em tempos diferentes de sua vida. Essa condição acabou por levar os estudiosos de sua obra a se debruçarem sobre temas isolados. Se é verdade que isso possibilitou uma rica produção sobre aspectos específicos da obra de Bogdánov, por outro lado dificultou a interface entre esses aspectos, fator que, em termos gerais, tem limitado o debate sobre o autor e impedido que aspectos importantes de seu trabalho sejam devidamente estudados (Bailes, $1977: 375$ ).

Nascido na cidade de Solkoko em 1873, Aleksandr Aleksandrovich Malinovskii (Bogdánov) formou-se médico em 1899, após estudar ciências naturais e medicina em Moscou e Kharkov, respectivamente. Foi nessa época, imediatamente anterior à revolução de 1905, que Bogdánov estabeleceu contato com alguns de seus principais apoiadores: Anatol Lunacharsky, Fedor Bazarov e Skvortsov-Stepanov, todos eles destinados a se tornar importantes membros do Estado Soviético após a revolução de 1917. Ao ingressar na universidade, Bogdánov filiou-se imediatamente ao Zemliatchestvo ${ }^{1}$ de Tula, tornando-se seu representante na União das Zemliatchestva. A partir dos anos 1890, intensificou-se a aproximação entre estudantes e operários, o que resultou na criação, em Moscou, de diversos círculos operários de formação e propaganda socialista e que contavam com a presença de jovens militantes social-democratas. Em 1894, após o assassinato de Alexandre III, diversos desses círculos foram desmantelados e seus membros encarcerados e exilados, Bogdánov ente eles (White, 2018:9).

Degredado de volta a Tula, cidade onde iniciou seus estudos, Bogdánov passou a ensinar economia política, em 1895, no grupo de estudos de trabalhadores fundado por Brusev e Gobulev. White (2018:15) salienta que tal experiência fora fundamental para a concepção de organização dos traba-

\footnotetext{
1 Zemliatchestva eram as principais sociedades estudantis nas universidades russas do fim do século XIX e eram compostas por estudantes advindos das mesmas regiões geográficas. Além de familiarizar os estudantes com o ambiente universitário e a vida na metrópole, as Zemliatchestva exerceram importante papel na radicalização da juventude estudantil russa e foram o berço político de importantes membros da Intelligentsia social-democrata, tais como Lenin e Kamenev (Kazan) (McClelland, 1971:822).
} 
lhadores elaborada por Bogdánov, em que caberia à Intelligentsia um papel auxiliar na emancipação intelectual dos trabalhadores e que fundamentou posteriormente o programa pedagógico das universidades vperedistas ${ }^{2}$ de Capri e Bolonha. Ao lado de Skvortsov-Stepanov, um jovem economista marxista que também havia sido exilado para Tula e com o qual ministrava os cursos, Bogdánov escreveu sua primeira obra voltada à introdução em estudos econômicos: "Curso Popular de Economia Política" (White, 2018:20). Foi nesse momento, de acordo com sua autobiografia, que Bogdánov abandonou o narodtchestvo ${ }^{3}$ em favor da crítica marxista, a seu ver mais adequada para analisar o desenvolvimento histórico da classe operária com a qual lidava diariamente (Bogdanov, $1974: 35)$.

Durante a cisão no Congresso de Genebra em 1903 - que colocou Lenin e Martov em lados opostos e resultou na criação das facções menchevique e bolchevique -, Bogdánov escolheu ficar ao lado de Lenin, tornando-se então um de seus principais colaboradores (White, 2018:99). Durante a maior parte do exílio de Lenin, Bogdánov foi, talvez, o principal intermediador entre o líder bolchevique e os membros da facção que ainda permaneciam na Rússia, condição essa possível graças à intensa atividade revolucionária à qual Bogdánov se dedicava (Jensen, 1978:32). Em 1904, Bogdánov publicou o primeiro volume de "Empiriomonismo: ensaios em filosofia". Nessa obra Bogdánov buscou incorporar ao que ele entendia como lacunas na teoria marxista conceitos teóricos produzidos por cientistas e filósofos da ciência como Ernst Mach, Richard Avenarius, Wilhelm Ostwald, Ernst Haeckel, Joseph Dietzgen e Hebert Spencer. Fundamentado no empiriocriticismo de Ernst Mach, Bogdánov buscou desenvolver uma teoria do conhecimento que, ao mesmo tempo em que se fundamentava na práxis social, rejeitasse sua interpretação a partir de categorias dicotômicas, como atividade/pensamento; sujeito/objeto; objetivo/subjetivo; matéria/espírito. Tais dicotomias seriam expressões da percepção gradativamente diversa dos agentes sociais do conjunto de saberes

2 "Vperedista" é o termo que designa o grupo de intelectuais que rompe com Lenin a partir do cisma bolchevique de 1909. Esta oposição antileninista reúne-se em tono do periódico "Vpered" (Вперед "Avante"), cujo título dá nome ao grupo

3 Narodtchestvo(народтчество) é о conjunto de atividades teóricas e práticas da Intelligentsia militante dos anos 1860 e 1870 que buscava responder e defender os interesses do narod russo e a construção do socialismo a partir da obshchina, a ancestral comuna russa (Laue, 1954:14). 
produzidos pela atividade social total, da qual se encontravam alienados pela causalidade fetichista da sociedade capitalista. A partir desse postulado, Bogdánov desenvolveu uma forma heterodoxa de marxismo, epistemologicamente fenomenológico e metodologicamente funcionalista (Boll, 1981:53). Uma descrição pormenorizada de sua teoria será realizada no Capítulo 2 deste trabalho.

Devido ao exercício da medicina, Bogdánov transitou entre as inúmeras vilas comunais localizadas entre São Petersburgo e Moscou, dirigindo e organizando diversas células bolcheviques clandestinas, uma vez que o partido se encontrava na ilegalidade. O destaque político de Bogdánov entre os bolcheviques era inegável: foi eleito para o Comitê Central do POSDR em 1905, 1906 e 1907; durante a Revolução de 1905, era o representante bolchevique junto ao soviete de São Petersburgo; além disso, atuou intensamente na redação de diversos veículos informativos bolcheviques como os jornais Vpered (Вперед “Avante"), Proletarii (Пролетарии - "Proletário") е Novaia Zhizn' (Новаиа Жизн' - "Vida Nova") (Jensen, 1978:36).

Outro fator a ser considerado quando se analisam as dificuldades encontradas no estudo da obra de Bogdánov foi a sua controvérsia com Lenin quanto ao futuro do programa tático bolchevique a partir de 1907. Esse evento trouxe consequências profundas para a vida de Bogdánov e, indiretamente, reverberou mesmo na formação política do Estado Soviético. O crescimento do revisionismo machiano ${ }^{4}$ levou Lenin a escrever seu único tratado filosófico: "Materializm i empiriokrititsizm" ("Materialismo e Empiriocriticismo"), em 1909, com o objetivo de combater o avanço do "relativismo reacionário" de Bogdánov. Tal controvérsia tem colocado estudiosos em campos opostos do debate ao envolver posições políticas subjacentes ao tema. Sochor (1988:36) identificou no bogdanovismo uma alternativa antiautoritária ao leninismo. A autora defende que a publicação de "Materialismo e empiriocriticismo" não serviu apenas para refutar Bogdánov. No afã de fazê-lo, Lenin acabou por lançar mão da dogmatização do marxismo, preparando o alicerce para

4 Ao nos referirmos aos marxistas russos influenciados pelo Empiriocriticismo de Richard Avenarius e Ernst Mach, utilizaremos o termo "machiano" (lê-se /ma.ki.a.no/). Com isso, evitamos o uso do termo "machista", cujo significado na língua portuguesa é sinônimo de misoginia e pode produzir erros de compreensão do texto. 
a ascensão de Stálin e municiando-o ideologicamente com o aparato teórico necessário para justificar os expurgos. Por outro lado, historiadores leninistas, como Aileen Kelly, defendem que a vitória de Lenin, ao privilegiar a política sobre o debate epistemológico, possibilitou a centralização do partido bolchevique, condição indispensável para o triunfo da Revolução de Outubro de 1917 (Kelly, 1990 : 314). De acordo com essas duas abordagens, a controvérsia entre as duas personagens se tratava menos de filosofia e muito mais de tática revolucionária.

Como veremos posteriormente no Capítulo 4, este trabalho propõe outra abordagem para o problema, situando a controvérsia estabelecida entre Lenin e Bogdánov em uma dimensão organizacional, acerca da natureza da luta revolucionária. Nesse momento nos interessará entender de forma mais precisa a maneira como essa controvérsia dialogou com a obra de Bogdánov e como veio a influenciar sua trajetória política e produção posterior. Na natureza dessas dificuldades encontram-se os objetivos desse trabalho. De que forma se pode apreender o diálogo de Bogdánov com seu próprio tempo de modo que caiba uma análise mais ampla da interface entre seus diversos interesses? Como o pensamento bognadoviano se relacionou com o próprio desenvolvimento da Intelligentsia social-democrata? E o que essa relação pode nos dizer sobre a riqueza dos debates político-econômicos que permearam as primeiras décadas do século XX?

As repostas para tais questões podem ser encontradas no caráter eclético de Bogdánov. Em meio ao seu debate com Lenin, Bogdánov, ainda otimista com a possibilidade de retomada do fervor revolucionário após a reação czarista, escreveu e publicou em 1908 "Estrela Vermelha", a primeira parte de uma trilogia de ficção científica (FC) ambientada em Marte. Através do olhar de Leonid, um jovem revolucionário bolchevique, Bogdánov, em sua narrativa, conduz seus leitores pelas características de uma utopia comunista resultante de uma revolução social levada a cabo trezentos anos antes dos eventos de 1905. 


\subsection{Utopia, radicalidade e ficção científica: Tradições impressas em "Estrela Vermelha"}

"Estrela Vermelha" abre uma janela para que se observem não apenas os sonhos e aspirações de um importante revolucionário bolchevique, mas também para o exercício em tentar demonstrar, na forma literária, a aplicação de suas teorias. Como utopia, a obra não leva o leitor ao futuro, uma vez que a história é contemporânea aos fatos com os quais o autor encontra-se profundamente comprometido; Bogdánov extrapola os limites espaciais da utopia, ambientando-a em outro planeta. Ali, não estão apenas descritas, mas prescritas suas sugestões sobre a profunda transformação econômica, social e política que espera a Rússia no devir de sua revolução. "Estrela Vermelha" pode, sob olhar estranhado do historiador, apresentar-se como um rico documento para estudar as implicações políticas e econômicas da obra de Bogdánov.

"Estrela Vermelha" começa e termina com a revolução. É nessa obra que se pode testemunhar, para além da disputa política do cotidiano, a intenção utópica de um bolchevique da velha guarda, suas aspirações, sonhos e reflexões. Bogdánov descreve ali diversos elementos da sociedade futura: seu sistema de produção industrial; a divisão sexual do trabalho; o sistema de ensino; a inexistência do Estado; o papel da produção científica; sua estrutura de agrícola; as redes de abastecimento; as questões sexuais etc. É uma obra escrita em meio às articulações de um processo revolucionário e que serve como interface entre o impulso utópico que dirige seu sujeito em direção à revolução e às necessidades imediatas determinadas pelas condições materiais impostas pela práxis política que constrói a mesma revolução.

Sua estrutura narrativa se assemelha à forma canônica da literatura utópica: um relato de viagem. "Estrela Vermelha" nos é apresentada na forma de um diário pertencente a Leonid, um jovem cientista e revolucionário bolchevique, cujo paradeiro é desconhecido após ter desaparecido de um hospital psiquiátrico. Lemos o diário de Leonid através dos olhos do Dr. 
Werner, seu médico e simpatizante. Leonid inicia sua jornada em meio à Revolução de 1905, na qual conhece um engenheiro chamado Menni que lhe propõe apresentá-lo a uma sociedade secreta de cientistas. Após passar por uma desilusão amorosa, Leonid aceita o convite e viaja com Menni para uma base localizada na Finlândia, de onde parte em um veículo movido a energia nuclear para Marte, o planeta vermelho.

Ali, Leonid atua como observador de uma sociedade que, em um passado distante, passou por uma revolução socialista global, decorrente de uma catástrofe ambiental que levou à desertificação do planeta. Esse evento decorreu da "experiência organizacional caótica e individualista do sistema capitalista", que ameaçava a própria existência da civilização marciana (Bogdanov, 1984 [1908] :33). A revolução e consequente destruição do sistema capitalista trouxe a construção, por meio dos esforços da classe trabalhadora, de uma sociedade coletivista e igualitária, cuja produção planificada atuava de acordo com as leis de equilíbrio econômico, supervisionada por "poderosos sistemas organizacionais estatísticos" (Bogdanov, 1984 [1908]:73). Tratado pelos marcianos como um embaixador entre os dois mundos, Leonid é levado a conhecer diversas das instituições marcianas: uma colônia educacional; um museu; uma fábrica de maquinários; um hospital. Conforme a narrativa progride, Leonid torna-se cada vez mais instável, demonstrando crescente dificuldade em se adequar à natureza coletivista do socialismo marciano.

Após sofrer diversos colapsos psicológicos, sempre sob os cuidados de Netti, sua amante marciana, Leonid encontra entre os arquivos do museu uma gravação das atas de reunião de um grupo composto por cientistas e estatísticos denominado "Grupo Colonial". Através da gravação, Leonid descobre que a sociedade marciana encontra-se à beira do colapso devido à escassez de alimentos causada pela redução de áreas agricultáveis. Frente a esse prognóstico, o grupo discute a necessidade do reassentamento em massa de sua população para outro planeta. Duas possibilidades se apresentam: a colonização de Vênus - cujo clima inóspito oferece obstáculos ainda incontornáveis; e a colonização da Terra, cujo principal obstáculo é sua população. Segue-se um debate acalorado entre as duas propostas: de um lado Sterni, um matemático de personalidade fria e analítica, que defende o extermínio 
da raça humana dada a impossibilidade de convivência entre o coletivismo do povo marciano e a selvageria e individualismo dos povos da Terra; do outro Netti, a amante de Leonid, que defende a intensificação de esforços na colonização de Vênus, uma vez que seria um crime indizível o extermínio de toda uma espécie senciente. Através da intervenção de Menni, a proposta de Netti sai vitoriosa, poupando a Terra de uma invasão. Leonid, no entanto, já psicologicamente fragilizado, acaba tomado por alucinações e, sob o temor de que a proposta de Sterni ganhe sobrevida, invade seu escritório e o assassina, entregando-se em seguida. Dias depois Leonid desperta no Hospital Psiquiátrico do Dr. Werner e passa a refletir sobre o fracasso de sua missão. A obra termina com sua fuga ao lado de Vladimir, um operário lutador de rua e seu pupilo, quando Leonid novamente se lança na luta revolucionária, agora sabendo que não caberia à sua geração de intelectuais guiar o processo revolucionário. Sua tarefa seria preparar Vladimir - a classe operária - para a vitória final.

Três importantes tradições se apresentam de forma imediata em "Estrela Vermelha", as quais trataremos de expor brevemente. Seu lugar na tradição literária da FC; o gênero utópico utilizado por Bogdánov para expôr seu exercício preditivo; e sua condição como tributária a uma longeva literatura radical.

Sob o ponto de vista dos estudos de FC, "Estrela Vermelha" deriva de uma consolidada linhagem de obras cujo espaço narrativo se passa em Marte, o planeta vermelho. O lugar privilegiado de Marte na FC se deve às possibilidades de vida inteligente que povoaram a imaginação dos escritores desde a primeira descrição do planeta realizada pelo astrônomo italiano Giovanni Schiaparelli, em 1877, que se utilizou do termo "Canalli" para descrever uma rede de linhas perpendiculares na latitude sul do planeta. Dois anos depois da publicação desses resultados, Percy Greg buscou descrever uma civilização alienígena nativa do planeta vermelho em "Across the Zodiac: The Story of a Wrecked Record" (1880). Em 1895 Percival Lowell publicou sua obra não-ficcional "Marte", em que descreveu os canais como sistemas de irrigação utilizados para conter o processo de desertificação do planeta. Inspirados na obra de Lowell, Kurd Lasswitz e H.G. Wells publicam, respectivamente, "Two 
Planets" (1898) e "Guerra dos Mundos" (1898). Esse panorama imagético não se restringe à passagem entre os séculos XIX e XX: basta lembrarmos das obras "A Princesa de Marte" (1912) e "John Carter of Mars" (1940) de Edgar Rice Burroughs; "Crônicas Marcianas" (1950), de Ray Bradbury; e em "Mars Trilogy" (1993) de Kim Stanley Robinson, obra que reabilitou o gênero utópico após duas décadas de hegemonia da literatura distópica (Stableford, 2006 : 29-33).

Em que medida "Estrela Vermelha" é tributária dessa tradição? Sabemos ao certo que as obras de H. G. Wells eram traduzidas para o russo logo a seguir de suas publicações no semanário "Vokrug Sveta” (Adams, 1989:4). Em 1905, H. G. Wells publicou um ensaio sobre a literatura utópica intitulado "Uma utopia moderna". Nesse ensaio, Wells defende que o gênero utópico deveria abandonar a forma do romance em favor de uma forma expositiva com vistas a superar as limitações do gênero presentes na literatura do século XIX:

\footnotetext{
"nada menos que um planeta servirá ao propósito de uma utopia moderna. [...] Esse mundo terá uma língua comum [...] e deverá haver a mais completa liberdade de ir e vir. Sua população terá características migratórias sem precedentes terráqueos. [A utopia] deve usar como valor monetário não uma substância, mas ao invés força, e o valor deve ser medido em unidades de energia" (Wells, 2009 [1905]:19, 25, 54,87 ) (tradução própria).
}

Esses elementos descritos por Wells como constitutivos da utopia moderna encontram-se presentes em "Estrela Vermelha" e foram publicados na Rússia dois anos antes de sua redação. Sem referências diretas, podemos apenas intuir que Bogdánov em larga medida se utilizou das definições de Wells para a elaboração de sua própria utopia.

Uma problemática comum aos estudos literários de FC se dá na dificuldade em categorizar a FC e a literatura utópica como gêneros distintos. No centro desse debate encontra-se a relação dialética entre forma e conteúdo. Essa questão acaba por obrigar-nos a olhar para a produção da literatura utópica russa sob o prisma da FC. Em sua obra seminal, "Metamorfoses da Ficção Científica", Darko Suvin definiu a literatura utópica como "subgênero político 
da FC" (Suvin, 1979:28). De acordo com Suvin, ainda que o gênero utópico preceda a FC, aquele é absorvido pela FC no século XIX por influência de uma tendência radical de seus escritores, utilizando-a como mecanismo narrativo que estimula na recepção da obra um processo de "estranhamento cognitivo". Através da plausibilidade do discurso científico, produz-se no átimo da leitura um afastamento das relações sociais nas quais o leitor encontra-se imerso, permitindo que ele se estranhe dessas relações e olhe criticamente para o contexto no qual está inserido.

Suvin opera o conceito de utopia a partir de uma chave estritamente contemporânea. Para o autor, aquilo que assemelha as utopias da era moderna, compostas literariamente como um gênero em si, das utopias contemporâneas, subsumidas na forma da FC enquanto subgênero político, é o caráter exclusivamente secular (Suvin, 1979:84). Essa abordagem é similar à definição que Martin Buber utilizou para distinguir as utopias do messianismo religioso, divorciando-as do mundo perfeito das escatologias religiosas construídas pela "intervenção divina". Para Buber, a característica central das utopias é o fato de que sua resolução se dá por meio da ação humana deliberada. Utopias são frutos da práxis política, enquanto escatologias são frutos da providência (Buber, $2007: 24$ ).

A utopia é, acima de tudo, um projeto historicamente delimitado. Jameson (1988) qualifica como sistêmico o projeto utópico inaugurado pela obra de Thomas More. De acordo com o autor, tal projeto:

"[...] incluirá uma prática política revolucionária quando buscar a fundação de uma sociedade inteiramente nova, ao lado de exercícios no gênero literário. Serão sistêmicas também as secessões utópicas autoconscientes, separadas da ordem social, então chamadas comunidades intencionais. Também ocorrerão tentativas de projetar novas totalidades sociais na própria estética da cidade." (Jameson, 2008:3) (tradução própria)

Tomam-se aqui essas caracterizações como pressupostos teóricos iniciais para pensar o conceito de utopia nesse trabalho: uma tentativa sistemática de propor, enquanto projeto político-econômico, a construção autoconsciente de uma comunidade intencional totalizante por meio da aplicação de uma 
ferramenta epistemológica construída a partir de um olhar crítico à sociedade do presente.

É a partir dessa categorização de utopia que é possível compreender a especificidade da literatura utópica russa. Darko Suvin apontou que sua força consistiu na relação dialética entre o específico e o universal, expressos por um lado em um desejo nativo por abundância e justiça; e por outro na recepção de correntes utópicas produzidas a partir do racionalismo ocidental. A particularidade da Intelligentsia, constituída no equilíbrio frágil entre o Ocidente e o Oriente, entre o moderno e o arcaico, entre o urbano e o rural, acabou por fornecer terreno fértil para o desenvolvimento de uma longa tradição utópica esteticamente radical e politicamente subversiva. Essa foi uma tradição inicialmente influenciada pelo idealismo alemão de Schiller e Hegel e que, conforme se radicalizava, aproximava-se cada vez mais da correntes materialistas de Feuerbach e, por fim, Marx (Branco, 2014 : 122).

Assim, "Estrela Vermelha" se insere na tradição literária radical russa, cuja história não pode ser desvinculada da própria história da Intelligentsia que a produziu. A partir do trabalho de Sônia Branco é possível verificar uma correlação direta entre o posicionamento estético da produção literária russa e de seus autores à crescente radicalização política dessa arte. Autores como Turgueniev, Goncharov, Tchernichevski, Pissarev, Gogol, Dobrolyubov e Tolstói produziram uma arte literária cujo papel buscava em grande parte refletir as condições objetivas da vida russa sob o peso do Estado autocrático, exigindo dessa arte um papel ativamente transformador (Branco, 2008:24). Trataremos essa tradição de forma mais pormenorizada no Capítulo 3. Nesse momento, precisamos apenas situar "Estrela Vermelha" na intersecção dessas três tradições (utópica, FC e política). A despeito do que diz Mark Bould, "Estrela Vermelha" não é uma obra original e inovadora (Miéville \& Bould, 2009: 12). "Chto delat?" (O que fazer?), de Nikolai Tchernichevski, antecedea em 48 anos, bem como também antecede "Respublika Yojnogo Kresta" (The Republic of the Southern Cross, 1907), do poeta simbolista Valery Bryusov. Decerto não foi pioneira na $\mathrm{FC}$, dada a rica tradição russa nesse gênero literário, à vista de obras como "Voyage to the Sun and Planet Mercury and All the Visible and Invisible Worlds" (1832) de Dmitry Sigov e "The 
forebears of Kalimeros: Alexander, son of Philip of Macedon" (1836) de Aleksandr Veltman. Como vimos anteriormente, Bogdánov se utilizou de diversas referências já produzidas anteriormente em obras de FC que se utilizaram de Marte como espaço dramático.

A originalidade da obra de "Estrela Vermelha", de acordo com Suvin, reside no fato de ser a primeira obra de FC utópica totalmente desgarrada de elementos literários típicos do gênero fantástico. É por essa razão que o pesquisador a considerou a "primeira obra de Ficção Científica utópica da literatura russa" e serviu como referência para diversos autores de FC soviéticos, como os irmãos Strugatski e Vladimir Efremov, os mais famosos escritores soviéticos desse gênero literário no Ocidente (Suvin, 1971 :145). Devemos acrescentar também o fato de Bogdánov partir dos fundamentos marxianos para descrever sua utopia, algo inédito entre escritores marxistas. "Estrela Vermelha" não é somente a primeira FC utópica soviética; é a primeira FC que buscou descrever o futuro de uma sociedade que superou a condição alienada de produção sob o prisma do marxismo.

"Estrela Vermelha" é a primeira obra de uma trilogia, seguida por "Engenheiro Menni" (1913) e "Um Marciano Náufrago na Terra" (1924). A obra recebeu entre 1908 e 1928 seis edições, todas esgotadas (Jensen, 1978: 42). "Engenheiro Menni" foi impresso em sete edições e sua última, impressa em 1923, contou com mais de 100.000 exemplares. Esses números, produzidos em um país com alto índice de analfabetismo, traduzem o impacto que a trilogia marciana de Bogdánov exerceu em sua recepção. Podemos citar, a título de exemplo, o discurso eulógico que Bukharin proferiu por circunstância da morte de Bogdánov em 1928. Bukharin afirmou que Bogdánov

\footnotetext{
"[v]iveu nesse partido [POSDR] como um de seus lideres durante um período histórico inteiro, o período dos primeiros ataques do proletariado, das primeiras sangrentas e heroicas batalhas, refletidas em sua representação artística nas últimas páginas de "Estrela Vermelha", páginas que a nossa juventude revolucionária lê com assombro e entusiasmo. Ele influenciou uma geração inteira de social-democratas e foi por conta dele que muitos camaradas tomaram sua decisão de se tornar revolucionários." (Bukharin, 1928:np)
}

Assim podemos perceber que "Estrela Vermelha", a despeito de alguns 
entusiastas, não é uma obra original em sua forma ou conteúdo. Ao contrário é uma obra intensamente derivativa e que se nutre de diversas tradições. Sua originalidade é contextual, caracterizada pela formação, posição e intencionalidade de seu autor. Como veremos a seguir, essas características combinadas nos fornecem um documento rico em possibilidades, que de forma alguma serão esgotadas por este trabalho. Utilizamos para nossa análise a tradução de David Rowley para a língua inglesa da terceira edição de "Estrela Vermelha" de 1922. De forma a garantir a integridade dos trechos selecionados, realizamos conjuntamente à análise o cotejamento da versão inglesa com a edição original da obra, "Krasnaya Zvezda". Todas as traduções apresentadas neste trabalho foram realizadas por este pesquisador.

\subsection{Fundamentação teórica e objetivos}

O uso de uma obra literária como fonte documental primária apresenta uma série de obstáculos metodológicos, mas também abre um conjunto de possibilidades. Entre as dificuldades que se apresentam, devemos ressaltar em primeiro lugar o problema ligado à exegese do documento. A composição de uma obra literária, sob o ponto de vista de sua produção, implica uma relação mediada entre uma vasta gama de espaços subjetivos e objetivos: as mentalidades do autor e dos receptores; o contexto socioeconômico; as contingências do cotidiano; a imersão dentro de um contexto histórico definido. A análise de uma obra literária exige como fundamento de sua exegese considerar a construção da obra a partir da articulação entre o pensamento e o espaço social, entre o específico produtor e a visão de mundo - aspirações, desejos e ideias - que o autor compartilha com determinado grupo social (Chartier, 2002:47). Tais mediações, por operarem entre os espaços social e da consciência, acabam por suavizar os limites categoriais desses mesmos espaços, dificultando para o historiador a tarefa de operá-los separadamente. O que pertence ao social e o que é representação produzida pela consciência social do autor - sua visão de mundo? De acordo com Roger Chartier esse é um obstáculo comum aos historiadores das mentalidades e que nos é presente ao analisar "Estrela Vermelha" (Chartier, 2009:42). Sempre haverá o risco 
de extrairmos do texto sentido que não lhe pertence ou que simplesmente não encontra no processo de reprodução social quaisquer ecos de reconhecimento.

O espaço limítrofe entre texto e contexto e os perigos que oculta para o ofício do historiador são protagonistas importantes da História da Historiografia. A virada linguística produzida pelos estudos semióticos nos anos 1960 e 1970, ao determinar a supremacia do texto sobre o contexto e da língua sobre o mundo social, produziu amplos debates acerca da diferenciação entre a História produzida pelos historiadores e os gêneros ficcionais. Na origem desse debate encontra-se a noção de que a linguagem é o agente constitutivo da consciência e força motriz para a produção de significados a partir dos estímulos produzidos pelo mundo. Dessa forma, a apreensão do passado só existe a partir das percepções que são por sua vez pré-codificadas pela linguagem (Spiegel, 2005 :2). Sob a primazia da língua, desaparecem as fronteiras entre objetivo e subjetivo, entre fato e ficção. Tudo torna-se discurso e passa a operar por meio de suas estruturas trópicas. Reduzida a narrativa, história e literatura não se diferenciam no ato de sua produção enquanto ferramentas discursivas. Essa abordagem formalista reduz todo o ato produtivo - textual ou contextual - a uma forma de texto, e a verdade a um critério coletivo de gosto (Veyne, 1998:19).

Não daremos conta do trajeto completo desse debate e de suas consequências para a Historiografia. Interessa-nos somente chamar a atenção para a dificuldade conceitual, corretamente apontada pelos pós-estruturalistas que estiveram à sua frente, em identificar e extrair do texto a visão de mundo do autor, em constante diálogo com a totalidade contextual. Sob uma perspectiva culturalista que busca explicar a cultura como uma esfera autônoma que media a relação entre o universal e o particular, a historiografia serviria como instrumento da cultura e não sua preservação inteligível; seu fazer é menos uma prática afastada - científica - de análise do passado e mais uma expressão narrativa e ordenada que a cultura produz de si mesma (de Certeau, $1988: 37)$.

Compartilhamos parcialmente de tais problemas por conta da natureza de nosso objeto, uma obra literária utópica, a saber: a mediação diáfana entre texto e contexto; a condição metanarrativa que emerge a partir da 
fragmentação do texto em face do recorte categorial selecionado; e a antinomia entre sincronia e diacronia. No entanto, acreditamos ser possível ultrapassar tais problemas a partir da escolha cuidadosa de um referencial teórico que privilegie uma hermenêutica que reforce os limites entre texto e contexto, compreendendo-os como partes dialéticas de uma totalidade. Esse referencial epistemológico precisa ser suplementado por uma operação metodológica que caracterize a obra como documento histórico, i.e. que registra em sua produção uma multitude de processos historicamente determinados e que podem ser objetivamente identificados sincronicamente e observados em seu movimento diacrônico.

Desse modo tomaremos como modelo epistemológico para nossa análise textual a hermenêutica marxista de Fredric Jameson, por entendê-la mais apropriada para interpretar as significações e elementos narrativos da obra de Bogdánov em uma mapa cognitivo das condições objetivas que as criaram. Jameson propõe, a partir do projeto de reconstrução do conceito de totalidade, uma leitura das representações literárias de uma obra e que expressam os elementos subjetivos do autor a partir de suas interfaces com a totalidade social ali presente, porém oculta e mesmo cifrada. Essa abordagem propõe uma 'desalienação' do texto ao fazer emergir marcos que permitam mapear elementos da totalidade ali contidos, ideológicos porque ocultam na narrativa contextos presentes, porém não representados (Jameson, 1991:51). Essa abordagem encontra-se de acordo com aquilo que Terry Eagleton definira como o objetivo principal da crítica marxista, isto é, conceber a forma não como um fim em si, mas "como produto de uma história determinada" (Eagleton, $1976: 15$ ).

A escolha de uma abordagem marxista torna o debate acima citado irrelevante. A indiferenciação entre texto e contexto força uma abordagem essencialmente formalista, uma vez que tudo se reduz à linguagem e, consequentemente, à sua forma. Essa redução, sob a ótica marxista, acaba por reproduzir as formas de idealismo tão criticadas por Marx que sustentam a primazia da consciência sobre a realidade. Em "A Ideologia Alemã", Marx afirma que:

"a produção de ideias, de representações, da consciência, está, em 
princípio, imediatamente entrelaçada com a atividade material e com o intercâmbio material dos homens, com a linguagem da vida real. O representar, o pensar, o intercâmbio espiritual dos homens ainda aparecem, aqui, como emanação direta de seu comportamento material." (Marx \& Engels, 2007 : 93).

É interessante notar que nessa passagem Marx se utiliza do termo "linguagem da vida real". Essa linguagem não se encontra codificada arbitrariamente na consciência ou no mundo, mas na relação dialética entre ambos que produz o movimento do processo histórico. Isso não significa que quaisquer abordagens de análise textual que tomem por fundamento o materialismo dialético sejam por definição antiformalistas; significa somente que um estudo formal do texto é mais um recorte metodológico que epistêmico. Estudar formalmente as relações arbitrárias entre significantes e significados não significa aceitar o específico enquanto elemento apartado do universal. O desenvolvimento histórico dos gêneros literários encontram-se imbricados com o desenvolvimento social da própria linguagem do mundo real (Williams, $1977: 53)$.

Para obter um mapa cognitivo que expresse a totalidade oculta sobre o texto de Aleksandr Bogdánov, utilizaremos como ferramenta metodológica o conceito de "história cruzada" proposto por Michael Werner e Bénédicte Zimmermann. Esse método é tradicionalmente utilizado para relacionar formações sociais, culturais e políticas em escala transnacional através da identificação e análise dessas categorias no momento específico de seus "cruzamentos", i.e. na materialização de elos que constituem seu objeto de pesquisa. Esse instrumental por isso insere-se no conjunto de procedimentos relacionais, assim como as histórias comparada e de transferência (Werner \& Zimmermann, 2003:90). Os autores defendem esse instrumental a partir da vantagem de operar para fora dos limites estreitos das abordagens sincrônicas e diacrônicas, aproveitando aquilo que consideram vantajoso em ambas: da sincrônica, a precisão de recorte das categorias; da diacrônica, a conservação do movimento de desenvolvimento dos objetos (Werner \& Zimmermann, $2003: 90)$.

Ainda que seja um método originalmente proposto para se pensar as 
relações entre espaços nacionais distintos, pensamos ser possível nos utilizar dele para pensar os cruzamentos entre textos e contextos dentro de uma obra literária que também é documento histórico. A partir da ótica proposta por Jameson, o texto literário pode ser entendido como espaço, a que ele poeticamente define como "geografia do sonhar" e que se encontra imbrincado com outros espaços: sociais, políticos, ideológicos (Jameson, 2005 : 52). Essa exegese espacial do texto torna-se atraente pela própria natureza do documento: uma obra literária utópica. A produção de um espaço imaginado que serve de reflexo negativo do presente ao mesmo tempo em que media a geografia mental do autor em relação à totalidade no qual está imerso nos possibilita através das justaposições entre os diversos "marcos" dessa geografia imaginária propor o cruzamento de conceitos e elementos da obra não apenas com seu momento exato de produção - sincronicamente - mas ampliar essa justaposição para compreender diacronicamente seu desenvolvimento. Será possível identificar não somente elementos maduros de seu pensamento, mas também apontar elementos embrionários - em status nascendi - que se desenvolverão posteriormente em formas acabadas. É por esse caminhar entre a sincronia e a diacronia que buscaremos adaptar as ferramentas da história cruzada ao estudo de uma obra literária, tomando o documento como um registro da mediação entre espaços distintos, entre o específico e o universal.

Assim sendo, mantendo como pano de fundo os diversos debates existentes entre a Intelligentsia russa sobre os caminhos políticos e econômicos a serem trilhados para a construção do socialismo, buscaremos a partir da análise cruzada de "Estrela Vermelha" atingir três objetivos específicos, a saber: situar o documento em sua época e indagá-lo a partir do debate contemporâneo sobre o período, o que inclui observar na obra apontamentos que elucidem as conexões entre os debates teóricos desenvolvidos pelos revolucionários russos e suas práxis políticas e, mais especificamente, entre Lenin e Bogdánov; observar que tipo de relações existiam entre, de um lado, a práxis revolucionária proposta por Bogdánov e a concepção (utópica) de sociedade e economia expressa em sua obra ficcional e em que grau essas relações expressavam a sua dependência em relação às formas materiais estabelecidas da propriedade da terra, da organização da produção industrial e 
das relações de trabalho e, consequentemente, das relações de classe; e refletir sobre a centralidade dada por Bogdánov à noção de fetichismo entre seus contemporâneos e as implicações disso para suas preocupações epistemológicas, por um lado, e para sua concepção de sociedade pós-revolucionária, por outro.

\subsection{Método expositivo}

Esta análise está estruturada em três capítulos, que serão descritos a seguir.

O Capítulo 2, "Considerações sobre o Empiriomonismo", servirá como um prolegômeno necessário para os capítulos posteriores. Dado o desconhecimento que existe acerca da obra filosófica de Bogdánov, geralmente vista pelo prisma de Lenin em "Materialismo e empiriocriticismo", julgamos necessário apresentar um texto introdutório à sua leitura do marxismo, elaborada a partir da exposição de sua obra "Filosofia da Vivência", publicada em 1913 como síntese de sua filosofia empiriomonista, que havia sido inaugurada nos três volumes de "Empiriomonismo" (Jensen, 1978:45). Nessas obras, Bogdánov buscou preencher aquilo que considerava lacunas nas principais correntes marxistas de sua época e introduziu ao materialismo histórico elementos do positivismo empiriocriticista de Richard Avenarius e Ernst Mach, produzindo com isso uma forma heterodoxa de marxismo fenomenológico que reduz a análise dialética a uma ferramenta secundária de apreensão do real pertencente a um conjunto de processos organizacionais. Sua teoria foi desenvolvida em meio aos primeiros debates acerca da epistemologia marxista no seio do POSDR, que envolveram Bogdánov e os marxistas legalistas, debate esse que será apresentado como panorama histórico para o desenvolvimento de suas ideias. A familiarização com os conceitos apresentados nesse capítulo se faz necessária para a melhor apreciação do trabalho subsequente.

O Capítulo 3, "Narodistas, marxistas e marcianos: Enclaves utópicos e espaços desalienados", trabalhará sobre o espaço imagético de "Estrela Vermelha" produzido por Bogdánov, pensando-o a partir dos primeiros debates empreendidos entre Plekhanov, Lenin e os narodistas no final do século XIX acerca das possibilidades de uma transição socialista a partir da obshchina, a ancestral comunidade rural russa. Esse debate, central para a formação da 
social-democracia russa, expõe uma tensão dialética constitutiva da própria Intelligentsia, a relação entre o rural e o urbano, entre o campo e a cidade. A partir dessa relação buscaremos demonstrar como Bogdánov expõe na organização do espaço utópico a superação dessas dicotomias a partir da unificação monística da experiência social e qual deveria ser o papel que ele entendia caber à arte nesse processo.

O quarto e último capítulo, "Entre o homem e a máquina": Classes sociais e produção em "Estrela Vermelha", tratará de dois momentos históricos distintos e de que forma ambos se cruzam como elementos contextuais de nosso documento. Primeiro trataremos do cisma do Comitê Central bolchevique de 1909 que levou à expulsão de Bogdánov e a consequente formação do grupo vperedista, composto por intelectuais ligados a Bogdánov e que se retiram ao seu lado para formar as universidades de Capri e Bolonha. Para tanto, buscaremos analisar as críticas de Plekhanov e Lenin à heterodoxia machiana a partir respectivamente das obras "Materialismus Militantis: reply to Mr. Bogdanov" (1907) e "Materialismo e Empiriocriticismo" (1909), de forma a compreender as diferenças conceituais entre o empiriocriticismo de Mach e o empiriomonismo de Bogdánov. Também discutiremos nesse momento alguns fundamentos da Tektologia, a ciência universal organizacional desenvolvida por Bogdánov que objetivava unificar os métodos científicos dos diferentes campos do saber e de que forma elementos embrionários desse projeto transpareceram em "Estrela Vermelha". Em seguida trataremos do debate acerca da implementação do taylorismo como paradigma para gerenciamento científico da produção no nascente estado soviético. Esse salto para os anos 1920 nos permite desenvolver, a partir da crítica de Bogdánov à visão tecnocrática de Alexei Gastev, sua contribuição para o pensamento econômico do período e suas propostas para planificação a partir da Teoria Geral do Equilíbrio, cujos elementos constitutivos já se encontram presentes, ainda que não plenamente desenvolvidos, em "Estrela Vermelha". Por fim, buscaremos integrar ambos os debates em uma exposição acerca do papel da Intelligentsia no processo revolucionário e da problematização das relações de autoridade que se justapõem como formas organizativas às relações de produção. Essas relações organizacionais - ideológicas - pertencem à esfera da 
cultura e deveriam, de acordo com Bogdánov, ser transformadas previamente à revolução através da formação de uma cultura operária.

Assim, "Estrela Vermelha" nos possibilita uma janela para compreender a articulação entre diversos fatores, objetivos e subjetivos, que compunham o alicerce teórico de uma teoria revolucionária que transcendia aspectos isolados - políticos, culturais, sociais -, entendendo-os como elementos constituintes de um continuum que se inicia antes de um processo revolucionário e se encerra muito depois de seu ato cataclísmico. 
2

\section{Considerações sobre o Empiriomonismo}

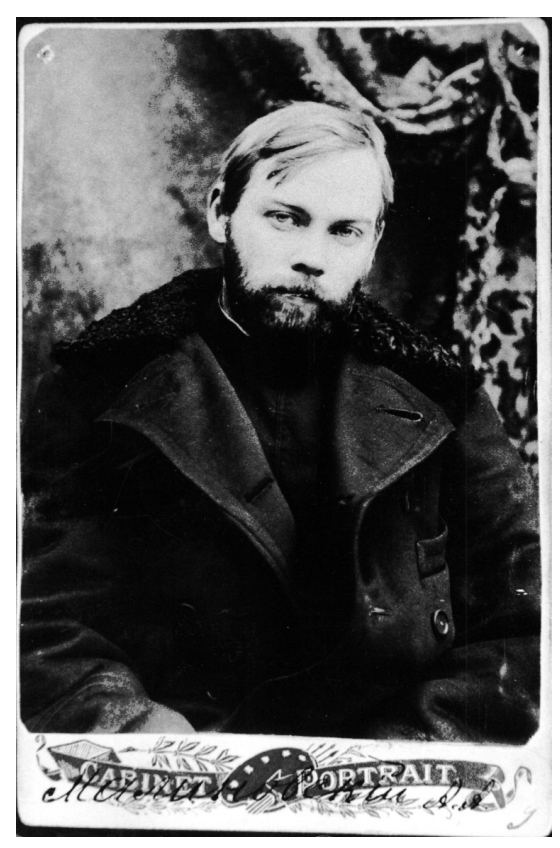

"A filosofia vive seus últimos dias. A fundação de uma nova ciência universal será lançada em um futuro próximo. Essa ciência desabrochará de um gigantesco e febril trabalho organizacional, o qual criará uma nova sociedade e trará o agonizante prólogo da História da humanidade a sua conclusão. Esse tempo não está distante..." 
Diversos cuidados devem ser tomados quando tratamos da obra e do pensamento de Aleksandr Bogdánov, tanto no que tange suas relações com o contexto histórico em que foram respectivamente produzidos e pensados, quanto as próprias avaliações a posteriori que foram feitas acerca de sua contribuição. Tais avaliações, ao dialogarem com o debate existente no seio da Intelligentsia russa da primeira década do século XX, acabam por dar preferência à polêmica entre Lenin e Bogdánov, preterindo o próprio estudo de sua obra. Esse foco dado pela historiografia da Revolução Russa à controvérsia acima citada, estabelecida entre os principais líderes bolcheviques, acaba por não apenas prejudicar uma análise objetiva das possíveis contribuições feitas por Bogdánov ao pensamento marxista russo de sua época, geralmente visto e analisado pela ótica de Lenin exposta em "Materialismo e Empiriocriticismo", como também reduz a um único momento o rico debate epistemológico que se estendeu por toda a primeira década do século XX, cuja historicidade sofre, por conta dessa determinação, um sensível apagamento.

No entanto, ao defender a necessidade de avaliar a obra de Bogdánov para além de seus críticos, a partir de seus próprios méritos e inconsistências, não propomos com isso que tais críticos sejam apartados dessa análise. $\mathrm{O}$ mero estudo textual acabaria por empobrecer a análise, uma vez que sua obra se desenvolveu a partir de um intenso e prolongado debate. Assim, para uma compreensão mais abrangente do desenvolvimento da obra de Bogdánov, faz-se necessário abordá-la de forma contextualizada, valorizando o debate epistemológico que marcou as primeiras décadas do marxismo russo. Tal contenda se debruçou sobre as fundações científicas do marxismo e apresentou três momentos críticos: as discussões estabelecidas entre Berdiaev e Bogdánov na virada do século XX; a controvérsia ultimatista ${ }^{1}$ entre Lenin e Bogdánov, decorrente do fracasso da revolução de 1905 e formação da Duma; e a publicação, em 1909, da obra "Materialismo e Empiriocriticismo" de

\footnotetext{
1 Tal controvérsia centrou-se no posicionamento da facção bolchevique quanto à participação de representantes do POSDR nas eleições para a III Duma. Posições conflitantes se desenvolveram em torno desta questão: de um lado Lenin, que via a participação parlamentar como uma nova frente de atuação contra a autocracia; o Boikottizm, liderado por Bogdánov, que defendia a não participação no processo eleitoral e aprofundamento das atividades de agitação; o Ultimatizm que defendia o controle direto dos deputados eleitos pelo CC do POSDR; e por fim, o Otzovizm, que defendia a expulsão de quaisquer delegados que contrariassem uma ordem do CC.
} 
Lenin (Rowley, 1996 : 23). Essa abordagem se justifica pelo protagonismo que Bogdánov exerceu em momentos críticos dessa discussão e que foi fundamental para a elaboração de suas própria teorias. Sua obra não pode ser vista de forma deslocada em relação ao desenvolvimento desse debate, uma vez que seu pensamento se constitui a partir de sua reação às próprias questões colocadas pela miríade de abordagens existentes no seio da Intelligentsia marxista russa, que buscava adequar uma leitura da realidade objetiva da Rússia do czares autocrática e desprovida de uma classe burguesa politicamente constituída - à possibilidade de construção de um movimento revolucionário profissional que levasse a cabo a revolução e implementasse em solo russo o projeto socialista.

A fim de atingir o objetivo acima proposto, isto é, compreender a evolução do pensamento de Bogdánov à luz dos debates empreendidos pelos marxistas russos, apresentaremos neste capítulo duas exposições correlatas, a saber: o desenvolvimento de sua teoria empiriomonista a partir do debate estabelecido entre Bogdánov e os marxistas neokantianos - notadamente Nikolai Berdiaev - acerca da moralidade revolucionária; e uma apresentação geral do empiriomonismo a partir da obra "Filosofia da Vivência", na qual Bogdánov compõe a síntese de suas reflexões gestadas durante os anos formativos do POSDR, período que compreende os debates epistemológicos produzidos pela Intelligentsia russa, da qual Bogdánov participou como um de seus principais protagonistas. A apresentação do debate Bogdánov/Berdiaev nos fornece um importante contexto histórico para compreender o desenvolvimento da epistemologia empiriomonista dentro de seus próprios limites teóricos. Essa exposição é também fundamental para compreender de forma mais rica as críticas de Lenin aos machianos russos em sua obra "Materialismo $e$ Empiriocriticismo", muitas vezes lida sem o conhecimento adequado sobre produção intelectual combatida ali pelo principal líder bolchevique. Estabelecida uma síntese do pensamento de Bogdánov, trataremos no Capítulo 4, especificamente, da controvérsia estabelecida entre ele e Lenin bem como das reverberações que tal debate produziu nos anos iniciais da Rússia Soviética. 


\subsection{O debate entre Bogdánov e Berdiaev: primeiros passos para o empiriomonismo}

Sob o recesso do movimento narodnik e em meio à ascensão do marxismo como principal base epistemológica da Intelligentsia russa a partir da última década do século XIX, Nicolai Berdiaev (1874-1948) se debruçou sobre a natureza moral da revolução. Tal questão era relevante e perpassou não apenas as reflexões de outros socialistas à época, como foi herdada dos debates envolvendo a Intelligentsia raznotchiniets dos anos 1870. Como veremos no Capítulo 3, o caráter voluntarista e o uso de táticas de ação direta marcaram profundamente as gerações socialistas posteriores (Branco, 2014:126). Para Lenin, o fracasso dos narodistas demonstrou ser necessária a consolidação de um programa de ação política direcionado por uma vanguarda revolucionária profissional e disciplinada, orientada pela constante análise da conjuntura política; por outro, demonstrou que a violência é uma realidade inafastável da revolução e, se evitável no processo revolucionário, inevitável na contrarrevolução que se seguiria. Por conta disso, Berdiaev acreditava ser necessário o estabelecimento de uma base moral que legitimasse a inevitável violência revolucionária. Em sua obra "Subjektivizm i individualizm v obshchestvennoy filosofi" (Subjetivismo e Individualismo na Filosofia Social, 1901), Berdiaev buscou em Kant o imperativo moral que justificasse a violência revolucionária e desse conta, ao mesmo tempo, da própria consciência individual dos revolucionários ali envolvidos. Seu trabalho se fundou na determinação objetiva da moral e do justo encontrada na ética absoluta de Kant. Para o autor, a categoria de justiça é dada por nossa consciência transcendental e é essa experiência apriorística que torna possível a vida e experiência moral (Rowley, 1996 :64). Para Berdiaev, essa categoria apriorística de justiça possibilitava uma justificação ética da violência revolucionária ao transferir a impessoalidade objetiva da revolução para o campo subjetivo da consciência revolucionária, atomizada na ação de seus sujeitos.

Tal formulação, ao colocar a responsabilidade moral da revolução no indivíduo, trazia profundos problemas para os marxistas ortodoxos. Em primeiro lugar, um problema tático: a formulação de Berdiaev arrefecia o 
fervor revolucionário, pois confrontava a inevitabilidade da revolução com a moralidade do revolucionário. Lenin considerava não ser coincidência o afastamento, no decorrer dos anos, dos seguidores de Berdiaev dos círculos revolucionários russos (Rowley, 1996 : xxi). Em segundo lugar, um problema epistemológico: compromissados com o materialismo, o determinismo e o socialismo científico, os marxistas ortodoxos encontravam pouco espaço para refutar o idealismo de Berdiaev, uma vez que a justificativa dos conceitos nos quais se baseava a ciência - e consequentemente, o marxismo - era o próprio propósito de Kant (Rowley, 1996 : xxii). Tal debate se concentrava na natureza das fundações científicas do marxismo. Anatol Lunacharski, em carta a Bogdánov, apontou que, ao tentarem refutar empiricamente a ética apriorística de Kant, os marxistas acabavam por minar outros conceitos apriorísticos desenvolvidos por Kant para restabelecer a objetividade científica do mundo frente ao ceticismo empirista inglês e nos quais se sustentava a própria noção de materialismo. Berdiaev insistia que, se algumas categorias apriorísticas possibilitavam a sustentação científica do marxismo, conferindolhe o sentido de verdade, também produziam o mesmo sentido de verdade para outras categorias apriorísticas, como justiça, moralidade e Deus (Rowley, 1996:66). Essas questões não compunham um caso meramente teórico. Naquele momento, a discussão epistemológica era crucial para a mobilização do movimento revolucionário. De sua resolução se daria o estabelecimento de um programa tático da vanguarda revolucionária.

Com o objetivo de refutar aquilo que considerava "idealismo burguês", Bogdánov tomou a frente desse debate. Ele procurou no empirismo uma forma de prover certeza à base científica do marxismo sem depender das categorias kantianas. Foi nas obras de Ernst Mach e Richard Avenarius, fundadores do Empiriocriticismo, que Bogdánov encontrou a base teórica para refutar os neokantianos, desenvolvendo a partir dela já em 1906 sua primeira grande obra: "Empiriomonizm: Stat'i po Filosofii" (Empiriomonismo: artigos em filosofia).

Para Ernst Mach, o mundo pode apenas ser apreendido por meio da experiência direta imediata. Dessa forma, é possível afirmar que não há "noumenon" - a coisa-em-si - uma vez que o mundo existe na relação 
entre elementos neutros, em estado de caos, que passam a existir como experiência organizada através dos processos de consciência. Para Avenarius, a realidade não passa de uma "textura", tecida na relação entre o observador e o observado (Banks, 2003:34, 47). A partir desse pressuposto, Bogdánov rejeitou a noção de verdade absoluta, qualquer que seja ela, e passou a definir a realidade em termos de experiência, em que a fronteira do mundo encontra-se parelha à percepção humana (Yassour, 1983:24). Para ele, a realidade passa a ser determinada pela experiência coletiva de uma sociedade. Essa afirmação confrontou o marxismo ortodoxo na medida em que Bogdánov colapsa um dos pilares do pensamento marxista: a ideia de que a existência determina a consciência. Para Bogdánov, a consciência é indivisível da existência, uma vez que ambas são construídas pela experiência e sua consequente organização na cognição. O mundo é idêntico à percepção que a humanidade dele desenvolve. O universo é um sistema monístico, cuja natureza externa é constantemente organizada a partir das ideias que os homens produzem dela com base em sua atividade laboral coletiva (Sochor, 1988 :28). A realidade, segundo Bogdánov, é feita das percepções compartilhadas pela consciência coletiva de uma dada comunidade. O mundo físico é a experiência coletivamente organizada. A partir da atividade social, complexos de elementos de natureza organizativa desenvolvem-se na cognição, auxiliando a organizar essas mesmas atividades sociais. A essa teoria fenomenológica Bogdánov intitulou "Empiriomonismo".

O trabalho, categoria ontológica essencial, é o processo humanizador que equilibra, por meio do confronto, os sistemas natural e social organizados. O trabalho é a base de toda experiência social organizada, pois delimita os parâmetros e limites das formas supraestruturais, as quais, por sua vez, modelam o sistema organizacional econômico. No entanto, diferentemente de Marx, Bogdánov não atribui à natureza dialética da luta de classes o processo de devir histórico. A luta de classes, para Bogdánov, acabava por ser a manifestação do confronto entre sistemas de organização de trabalho distintos, cujo resultado gerava uma superação e um novo equilíbrio (Bogdanov, 2016 [1913] : 282). Em cada estágio de desenvolvimento, determinada classe social acabava por deter o conhecimento das técnicas de produção e o controle organizacional do processo de trabalho, tornando-se protetora de 
seus privilégios e poder. No entanto, com o avanço de formas cada vez mais complexas de organização do trabalho e do conhecimento, tal classe acabava por ser suplantada por formas e grupos sociais mais eficientes, que proveriam o próximo estágio econômico com novas técnicas (Rowley, 1996:11).

Da mesma forma que a consciência é indivisível da existência, a ideologia de uma sociedade - a superestrutura - não se encontra submetida às relações econômicas de produção: ela é tal relação, a partir do momento que é a ideologia que unifica e coordena a atividade humana. O controle da técnica, ciência e cultura adequadas a sistemas organizacionais de trabalho mais eficientes é, para Bogdánov, a condição para a superação da sociedade burguesa. O socialismo proveria uma forma mais eficiente de organização da atividade produtiva, pois no manejo racional da economia - o fim da alienação produzida pelo confronto entre o trabalhador e o trabalho - o proletariado eliminaria todas as formas de autonomização da experiência coletivamente organizada. A classe proletária se tornaria mestre da ideologia da maquinofatura, a fundação ideológica do socialismo (Rowley, 1996 : 12).

A partir desses postulados, Bogdánov recusa a divisão entre o subjetivo e o objetivo; entre o "espírito" e a "matéria"; entre o fenômeno e a coisa-em-si. Tais divisões existem enquanto atavismos do sistema capitalista e respondem às categorias de fetiche e reificação propostas por Marx. Com isso Bogdánov reafirmou a inevitabilidade histórica da revolução sem precisar refutar diretamente as categorias kantianas, isentando a atividade revolucionária de qualquer princípio apriorístico moral. De acordo com Rowley (1996), Bogdánov recusou tanto o economicismo bernsteiniano - que entregava a liderança da revolução à burguesia democrata - quanto o idealismo do círculo de Berdiaev - que se retirava da ação revolucionária em favor de abstrações teóricas. Bogdánov, em sua forma peculiar, amarrou por meio desse debate a práxis política às questões epistemológicas correntes, aliando-se nesse momento a Lenin ao defender a necessidade de lideranças revolucionárias comprometidas integralmente com as necessidades da revolução. Essas proposições ajudam a explicar a forte atração que Bogdánov sentiu pelo modelo centralizado e disciplinado de partido revolucionário proposto por Lenin. Tais lideranças surgiriam de dentro da Intelligentsia e teriam papel ativo na organização da 
classe trabalhadora, através de uma disciplina partidária e estrita, totalmente dedicada aos ideais e à práxis revolucionária (Mansueto, 1996: 40). Bogdánov defendeu que a revolução seria determinada por condições objetivas, que a Intelligentsia detinha um papel a ser realizado nesse processo e que quaisquer considerações morais ou éticas seriam irrelevantes.

Este debate encontra-se representado em "Estrela Vermelha" logo em suas primeiras páginas, através do contraste entre as posições de Leonid e Anna Nikolaevna, sua amante menchevique. Leonid despreza o caráter moralístico de sacrifício e dever que sua companheira nutre em relação à revolução. Leonid se jacta de ter aderido à revolução "sob a bandeira de seu livre-arbítrio". Enquanto Anna se une ao movimento operário porque "encontrou satisfação em sua suprema moralidade", Leonid explica que "simplesmente amava a vida e queria que a mesma florescesse o quanto fosse possível" (Bogdanov, 1984 [1908]:25). Assim como os marxistas neokantianos do círculo de Berdiaev, Anna defende que "a ética de classe do proletariado se tornará o código moral universal" (Bogdanov, 1984 [1908] : 25). Leonid por outro lado filia-se à irrelevância que Bogdanov dedicou nesse debate a tais questões. Para Leonid:

"Eu acreditava que o proletariado já se movia na direção da destruição de toda a moral e que o sentimento de camaradagem que uniria os povos em labor, alegria e sofrimento não se desenvolveria totalmente até que lançassem por terra a carcaça fetichística da moralidade." (Bogdanov, 1984 [1908] : 25)

Como produto desse debate, Bogdánov produziu um amálgama entre as teorias de Marx e Mach. Ao recusar as categorias apriorísticas neo-kantianas, Bogdánov acreditou ser possível compatibilizar as epistemologias positivista e marxista de forma a construir um alicerce teórico que sustentasse a prática revolucionária. É importante ressaltar que ainda que tenham trabalhado juntos por muitos anos na construção da facção bolchevique, Lenin sempre se colocou como um feroz opositor à filosofia de Bogdánov, condição que levará à ruptura entre ambos a partir de 1907. Dada a importância que essa controvérsia teve no desenvolvimento do pensamento de Bogdánov, trataremos dela de forma pormenorizada no Capítulo 4. Esta escolha se 
justifica pela necessidade em apresentar previamente os elementos essenciais do empiriomonismo bogdanoviano, raramente lidos a partir do texto de Bogdánov. Acreditamos que o estudo prévio de sua obra nos permitirá fazer uma leitura mais rica, tanto da crítica leninista expressa em "Materialismo e Empiriocriticismo", quanto de "Estrela Vermelha", documento primário cuja análise orienta este trabalho.

\subsection{A Filosofia da Vivência}

Escrito entre os anos de 1910 e 1911, "Filosofia da Vivência" se insere em um contexto de grandes transformações para Bogdánov. Em suas páginas podemos observar a forma acabada de sua filosofia empiriomonista, fruto de anos de reflexões, desde a publicação de seus primeiros ensaios sobre o tema em "Empiriomonismo: Ensaios Filosóficos" (1903). Sua publicação também acompanha o lento e irreversível afastamento de seu autor das atividades revolucionárias, favorecendo os aspectos culturais da revolução em detrimento de seus aspectos políticos, processo que se iniciou com sua expulsão da facção bolchevique em 1909 (Brandist, 2012 :27). Para Bogdánov, as principais tarefas revolucionárias de seu tempo seriam: fazer contraposição à cultura burguesa; criar e difundir entre as massas uma nova cultura proletária; desenvolver a ciência proletária; estreitar as relações de camaradagem em círculos proletários; desenvolver a filosofia proletária e direcionar a arte de forma a exprimir as buscas e experiências proletárias (Bogdanov, 2016 [1913] : 12).

Essa posição fica mais clara em um artigo publicado em 1912 por Bogdánov, intitulado "Socialismo no presente". Nesse artigo, Bogdánov defendeu que o desenvolvimento de uma cultura operária na qual o socialismo se assentaria deveria preceder a revolução, e não segui-la: a luta pelo socialismo não se resume em uma única guerra contra o capitalismo e na simples coleção de forças para aquela tarefa. Essa luta é um trabalho positivo e criativo: "É a criação de novos elementos do socialismo no proletariado: em suas relações internas, em suas condições de vivência. É o trabalho de formação de uma cultura operária e socialista" (Bogdánov, 1912, apud Biggart 1987 :233). 
Após a Revolução de 1917, a convite de Lunacharsky, o primeiro Comissário do Esclarecimento, Bogdánov colaborou com a criação do Proletkult, uma rede de grupos culturais compostos por trabalhadores cuja capilaridade se estendeu por toda a Rússia.

De acordo com Rowley (1996), os princípios da Cultura Proletária de Bogdánov faziam parte de um processo de transição entre o empiriomonismo e a Tektologia $^{2}$, seus dois mais importantes projetos filosóficos. Essa colocação é fundamental para nossa leitura: ao mesmo tempo que "Filosofia da Vivência" é reconhecida como a síntese madura e última do empiriomonismo bogdanoviano, essa obra também pode ser vista como uma peça introdutória para seu magnum opus, a obra pela qual Bogdánov estabelecerá seu legado: os três volumes da "Tektologia" (Rowley, 1984:xi). Não trataremos neste trabalho da Tektologia enquanto objeto definido. Nosso escopo se limitará à análise das nuances do pensamento de Bogdánov expressos em "Estrela Vermelha", de forma a compreender a projeção utópica que o autor produziu sobre as possibilidades e futuros possíveis de uma sociedade comunista. Podemos afirmar que há em "Estrela Vermelha" diversas reflexões sobre a Tektologia, o que indica que seu projeto de construção da ciência organizacional já existia em 1908 e mostrava um avançado grau de desenvolvimento. No entanto, acreditamos ser possível produzir, por meio de uma análise processual de seu texto a partir de suas posições epistemológicas condensadas em "Filosofia da Vivência", considerações sobre elementos já presentes em sua narrativa e que vão compor, nos anos seguintes, formas mais acabadas de seu pensamento.

A obra "Filosofia da Vivência" é dividida em seis capítulos. Na introdução, Bogdánov trata daquilo que enxerga como crise da filosofia; no primeiro capítulo, "O que é materialismo?", Bogdánov defende a natureza ativa da experiência sobre as sensações, bem como a origem física de todo o conhecimento a partir da atividade laboral; no segundo capítulo, denominado "Materialismo Antigo", o autor contempla o desenvolvimento do materialismo na filosofia grega a partir do princípio de sociomorfismo e defende o desenvolvimento do

2 Em sua autobiografia, Bogdánov descreveu a Tektologia como "um estudo geral das formas e leis de organização de todos os elementos da natureza, prática e pensamento" (Bogdanov, 1974:44). De acordo com Gorelik, o objetivo da Tektologia era fornecer as bases epistemológicas para a tranposição de modelos científicos entre campos distintos do saber (Gorelik, 1983:39). Apresentaremos alguns de seus conceitos gerais no Capítulo 4. 
materialismo enquanto modelo mental derivado das práticas sociais; o terceiro capítulo, "Materialismo moderno", trata do desenvolvimento do materialismo na modernidade a partir dos elementos constitutivos da sociedade de troca: a causalidade abstrata e o individualismo; em "Empiriocriticismo", o quarto capítulo da obra, Bogdánov explica a filosofia de Avenarius e Mach como um produto da "Intelligentsia especialista", posicionada entre a burguesia e o proletariado; o capítulo 5 é reservado para a crítica de Bogdánov ao materialismo dialético, notadamente às leis dialéticas da "qualidade e quantidade" e "negação da negação" apresentadas por Engels em "Anti-Duhring"; o sexto capítulo apresenta o empiriomonismo como a filosofia do proletariado, cujos elementos derivam sociomorficamente da maquinofatura.

Há motivos para esta breve descrição dos temas tratados por Bogdánov em sua obra. Diversos estudiosos, como Ballestrem (1969) e Marot (1990), defendem ser "Filosofia da vivência" uma organização de ensaios fechados, que podem ser lidos de forma independente. Este trabalho, no entanto, rejeita tal constatação. Bogdánov realiza considerável esforço em demonstrar a aplicação de sua teoria do sociomorfismo - a ideia de que as ideologias são determinadas pelas relações sociais de produção ao mesmo tempo em que as reforçam - por toda a extensão da obra. Além disso, como salienta Rowley (1984), não há quaisquer rejeições explícitas aos pensamentos empiriocriticista e marxista em sua obra. Bogdánov se propõe a realizar uma síntese entre Marx e Mach e produzir uma superação de seus pensamentos: Bogdánov ultrapassa Mach apenas na medida em que ancora o conhecimento em uma fundação marxista baseada no trabalho coletivo socialmente orientado; e ultrapassa Marx apenas na medida em que alicerça os conceitos marxistas em uma epistemologia explicitamente empirista (Rowley, 1984). Discutemse na sequência três capítulos de "Filosofia da Vivência", cuja leitura nos possibilita sintetizar o pensamento bogdanoviano.

\subsubsection{Introdução da obra}

Bogdánov apresenta três ensaios introdutórios em que busca tratar do "problema da filosofia" e sua relação com o homem contemporâneo. O autor 
começa seu trabalho expressando aquilo que entende ser um consenso entre a maioria das pessoas, quando questionadas sobre a função da filosofia e dos filósofos: a filosofia é algo complicado e desnecessário na vida cotidiana; e os filósofos são pessoas que vivem fora da realidade, desinteressados na fortuna das outras pessoas e incapazes de perceber o mundo ao seu redor. Para contrapor tal lugar comum, Bogdánov convoca em seu texto as reflexões de um "filósofo-trabalhador", o tecelão Arkardi Fedorov. Questionado sobre a razões de tal consenso, Fedorov explica que tal visão se dá pelo fato de que

“... a filosofia sistemática sempre foi estudada por pessoas que nada tinham em comum com o trabalho do povo. Libertos do trabalho, mas consumindo seus frutos, foram sempre esses que tiveram tempo e recursos para estudar [...] o abismo que separa a prática da filosofia é o mesmo que existe entre aqueles que trabalham e aqueles que apenas consomem os produtos do trabalho alheio." (Bogdanov, 2016 [1913]:1)

A seguir Fedorov explica que todas as pessoas produzem filosofia e, se não percebem, isso se dá por uma compreensão limitada e confusa daquilo que é filosofia: as pessoas não percebem que tudo aquilo que fazem em vida passa pelo prisma de sua própria filosofia, uma filosofia caseira.

"[...] todos os costumes assimilados, as morais, regras, religião e conhecimento que acontece de alguém adquirir são de uma forma ou outra uma visão de mundo, em efeito uma filosofia." (Bogdanov, 2016 [1913]:2)

O filósofo tenta então diferenciar essa forma individual de filosofia daquilo que chama de "filosofia científica". A filosofia caseira é composta por tudo aquilo que vem de forma espontânea e inconsciente da vida e que é verificado por indivíduos separados e, naqueles indivíduos, forma um sistema fechado em si. Em contraste a filosofia científica consiste na experiência vivida pela humanidade que é verificada pelas forças coletivas e organizada em um sistema por essas mesmas forças (Bogdanov, 2016 [1913] :2).

A partir daqui, Bogdánov estabelece duas formas distintas de filosofia. A primeira é a filosofia "caseira", caracterizada pela apreensão e sistematização do conhecimento a partir das experiências individuais produzidas na luta pela 
existência. No entanto, ele ressalta que tal categoria é susceptível a erros e desvios, uma vez que depende das experiências individuais, cujo escopo de apreensão dos elementos constituintes do real é limitado temporal e espacialmente. Tais experiências se limitam a uma parte reduzida da experiência social total à qual os indivíduos têm acesso, parte essa determinada pelas condições de reprodução social, de grupos pequenos e autônomos às classes sociais pertencentes a sociedades complexas (Bogdanov, 2016 [1913] : 8). A segunda é a "filosofia científica", cuja característica repousa na organização sistemática da experiência coletiva de um povo. Tal filosofia repousa na sistematização do conhecimento acumulado a partir da experiência social total e que por isso é passível de aferimento e reprodutibilidade.

A principal diferença entre as duas formas de filosofia repousa na intensidade de sua relação com a experiência social total. A filosofia caseira, produzida pelos indivíduos como ferramenta de orientação para a sobrevivência, apresenta níveis mais simples de organização do conhecimento, uma vez que interage apenas com uma pequena parcela da experiência social total. A filosofia científica, produzida pelas forças sociais coletivas, é capaz de ordenar elementos mais complexos dessa mesma experiência e, com isso, desenvolver sistemas de conhecimento científicos e filosóficos mais sofisticados. Bogdánov utiliza como exemplo uma formulação filosófico-científica de Marx: “...A ideia que sustenta a visão de mundo sócio-histórica proletária: a consciência social é determinada pelo ser social" (Bogdanov, 2016 [1913] :6). Bogdánov argumenta que, tal como um provérbio popular, tal formulação se originou da experiência coletiva da humanidade. No entanto, a formulação de Marx é baseada em uma sistematização do conhecimento muito mais ampla do que é capaz um simples provérbio e, por isso, se aproxima mais da totalidade da experiência coletiva. Marx utilizou uma enorme quantidade de dados, operados pelos métodos mais avançados de sua época, os quais haviam sido organizados pelo esforço coletivo de gerações de pensadores, economistas, naturalistas e filósofos, para produzir a mais completa análise das tendências de desenvolvimento da sociedade contemporânea. Assim, "O Capital" foi o produto acabado da experiência coletiva aferida por métodos coletivamente formulados (Bogdanov, 2016 [1913]: 9). 
Já nas primeiras páginas introdutórias podemos perceber a natureza materialista da epistemologia bogdanoviana: toda a forma de conhecimento sistematizado nasce da experiência e necessidades coletivas, bem como é verificada e moldada pela prática coletiva - o trabalho. No entanto, quanto mais amplo e aferível é esse sistema de conhecimento, mais científico é o seu conteúdo. Quanto mais cresce a experiência total da humanidade, mas úteis se tornam tais sistemas na organização do trabalho social, mais amplos se tornam seus significados e, portanto, mais científicos (Bogdanov, 2016 [1913] : 8). Para Bogdánov, a forma mais avançada que qualquer filosofia em um dado tempo histórico pode adquirir é científica. Bogdánov toca de forma tangencial na questão das classes sociais. A perspectiva científica - isto é, a visão de mundo mais próxima da totalidade do conhecimento acumulado - pertence historicamente à classe social mais progressista no reino coletivo das classes sociais (Bogdanov, 2016 [1913] : 9). Indivíduos podem atuar como "decodificadores", agentes na relação entre o particular e o universal. No entanto, a perspectiva científica pertence hegemonicamente à classe social mais progressista.

As filosofias caseira e científica encontram-se sempre em eterno confronto, operando dialeticamente suas contradições. Isso decorre, de acordo com Bogdánov, da limitação imanente à psicologia dos indivíduos em organizar o conhecimento produzido pela experiência coletiva. Esta limitação explica porque, na maioria das vezes, um membro de determinada classe social compartilha de elementos pertencentes à visão de mundo de outras classes sociais. Esse processo, para Bogdánov, é intensificado no mundo burguês por meio do processo de atomização do conhecimento e da reificação das relações sociais. A sociedade de trocas, baseada na divisão de classes e na propriedade privada, depende da intensificação constante da divisão social do trabalho. Assim, o mundo burguês leva à divisão extrema da experiência coletiva, fenômeno que produz a especialização da produção e da cognição, reduzindo drasticamente os limites das experiências individuais e alienando as pessoas em si e entre si: cada divisão da produção cria suas próprias terminologias especiais, seja a tecelagem, a produção mecânica, a matemática ou as ciências sociais. 
"Quando um mecânico fala sobre a conexão de eixos e guias ou um matemático fala sobre integrais e derivadas, a maioria das pessoas não entende do que estão falando. A Filosofia, quando se torna uma especialidade, supera todas as outras áreas nesse quesito." (Bogdanov, 2016 [1913]:11)

Com isso Bogdánov busca responder à questão colocada no começo de sua introdução: as pessoas não compreendem a filosofia e os filósofos devido ao processo de especialização gestado pelo mundo burguês e, ao não compreenderem, são incapazes de organizar a filosofia como elemento de seus sistemas individuais de conhecimento. A Filosofia torna-se algo alienígena, alheio. Para Bogdánov, a filosofia tem a função de unificar a experiência total de todas as gerações em um sistema rigoroso e consistente, capaz de explicar o mundo. Consequentemente, a filosofia deveria ser capaz de extrair os elementos da experiência produzidos por todas as ciências e de todas as atividades laborais, unificando-os em um sistema único e coeso de generalizações. Resumidamente, deveria ser a filosofia a fundação real da ciência. O campo de atuação da filosofia é tão amplo quanto a vida e se funde com ela (Jensen, 1978:22).

No entanto, afetada pela reificação produzida pela sociedade burguesa, a filosofia se mostra incapaz de realizar sua missão unificadora. Ao se ver apartada da experiência total, a filosofia perde seu contato com a práxis social e se volta à busca de verdades fantasmagóricas e eternas, que existem de forma independente à experiência coletiva, separadas das relações objetivas de produção. Para Bogdánov a filosofia:

"[...] é filha do trabalho e do conflito; cresce e se transforma com eles. Quando uma poderosa classe social, contemplada pela história com grandes e novas tarefas, entra na arena da história, então uma nova filosofia inevitavelmente emerge. Essa classe, possuidora do futuro, deve forjar sua própria filosofia, uma filosofia que se torna uma ferramenta indispensável para sua vitória." (Bogdanov, 2016 $[1913]: 10)$

Bogdánov vê a filosofia como uma ferramenta de orientação para todos os agentes da experiência, desde indivíduos até classes sociais. Cada classe social produz sua própria filosofia, que lhe auxilia na luta pela hegemonia social e, 
ainda que indivíduos possam sistematizar elementos produzidos por filosofias diferentes, não são coletivamente intercambiáveis. A filosofia de uma classe é a mais avançada forma de sua consciência coletiva e é por meio dela que os indivíduos despertam sua consciência de classe e participam daí como agentes na luta social. Bogdánov acredita que o problema da filosofia contemporânea se dá pelo seu afastamento de sua função histórica: servir como ferramenta de orientação para a prática e para o pensamento, em suma, para a vida em sua integralidade (Jensen, 1978: 25).

A segunda e terceira parte da Introdução apresentam o conceito bogdanoviano de "visão de mundo" ${ }^{3}$ e podem ser divididas em quatro momentos: a busca por estabelecer a origem do pensamento e como o mesmo veio a ser sistematizado em visões de mundo; a descrição dos elementos fundamentais primeiras formas de visão de mundo - e as origens da noção de causalidade; o declínio das visões de mundo religiosas e a sucessão do pensamento secular, que apresenta uma noção de causalidade distinta; por fim, a relação entre o pensamentos religioso e secular no tempo presente e os problemas que tal relação gesta. Bogdánov elabora uma periodização da história do pensamento, dividindo-a em três fases: a fase primitiva ou pré-religiosa, a fase religiosa e a fase secular.

$\mathrm{Na}$ fase primitiva inexistem quaisquer formas de conhecimento organizado. Isso não significa que as sociedades humanas fossem desprovidas de conhecimento, apenas que o mesmo não era sistematizado. A sistematização do conhecimento para Bogdánov depende de que os produtos da mente sejam organizados coletivamente. Para tanto era necessária uma ferramenta que permitisse a classificação e ordenação dos elementos componentes da experiência que auxiliassem os homens em seu confronto com a natureza: a linguagem.

3 Escolhemos o termo "visão de mundo" a partir da tradução inglesa da obra, a qual traduz "Mirovozzrenie", como "worldview". No entanto, este trabalho parte do pressuposto não ser essa uma tradução adequada. "Mir" pode ser traduzido como mundo, mas tem um significado mais amplo: também é utilizado para designar a totalidade social das comunas campesinas russas. Bogdánov utiliza esse termo "Mirovozzrenie" para designar um paradigma organizador do pensamento derivado das relações causais determinadas pela experiência do trabalho. Em russo, "Mir" acrescenta ao conceito o universo da sociabilidade como campo de atuação do real, do "mundo". Em inglês e português, a tradução perde esse elemento do mundo social. O termo carrega um sentido individualístico, subjetivo. Na dificuldade em encontrar um termo na língua portuguesa que abarcasse o significado amplo que o conceito apresenta em sua língua original, acabamos por utilizar a forma "visão de mundo", atentando para a ressalva expressa nesta nota. 
Bogdánov não diferencia os elementos da linguagem e do pensamento. Ambos surgem dos sons utilizados para coordenar o trabalho coletivo. As "palavras-ideias" surgem como designações das ações empregadas no confronto com o mundo natural. "Cogitações e pensamentos não são nada além de linguagem interna e desvocalizada. [...] a raiz inicial das palavras eram sons produzidos espontaneamente, conectados com atividades humanas" (Bogdanov, 2016 [1913]:15). Naquele estágio de desenvolvimento - o qual Bogdánov denomina como sociedades caçadoras-coletoras - o mundo humano ainda era um mundo de ação. As primeiras palavras-ideias eram verbos cuja expressão era acompanhada de um ato de labor e cujo sentido passava a ser compartilhado coletivamente. Com o incremento da experiência coletiva, substantivos surgem para designar as ferramentas que auxiliam os homens em suas atividades laborais. A designação das ferramentas marca também os primeiros passos no desenvolvimento da divisão social do trabalho. Ao serem designadas, indica-se que tais ferramentas já não são diretamente extraídas da natureza e precisam ser discriminadas das atividades com que se relacionam.

Para Bogdánov, sem o desenvolvimento da fala é impossível que qualquer forma de visão de mundo possa existir. Uma visão de mundo pressupõe um sistema, uma interconectividade organizada entre os elementos do conhecimento e uma contínua correlação entre eles. Toda visão de mundo é estruturada a partir de um método específico que forma a sua essência e que surge a partir da organização social do trabalho. A esse método Bogdanov (2016 [1913] : 28) chama de "interconectividade causal", que reflete na consciência a própria vivência, a luta contra a natureza, cujos elementos são sistematizados por meio da visão de mundo.

Bogdánov propõe ser a linguagem a primeira forma ideológica que emerge das atividades laborais, cuja função espelha essas relações ao mesmo tempo em que as organiza. Dessa forma, a língua reflete psiquicamente a objetividade do mundo e a forma como os homens atuam socialmente. O autor tenta reforçar essa ideia através da dificuldade que Leonid encontra em compreender a linguagem marciana:

"A língua [marciana] é muito original e, a despeito da grande simplicidade de sua gramática e regras de derivação, há peculiaridades 
que achei difíceis de dominar. Suas regras não têm nenhuma exceção e não há limitações como gêneros masculino, feminino e neutro. Ao mesmo tempo, no entanto, os nomes de todos os objetos e qualidades são declinados de acordo com seu estado temporal." (Bogdanov, 1984 [1908]:48)

Ao questionar Netti a respeito dessas formas, a marciana responde:

"Existe na natureza uma diferença maior que aquela entre um homem que está vivo e um homem que já morreu - entre aquilo que é e aquilo que não é? Você precisa de palavras e sentenças inteiras para expressar essa distinção. Não é melhor indicá-la simplesmente adicionando uma letra à mesma palavra?" (Bogdanov, 1984 [1908]:48)

Bogdánov usa essa breve descrição para expôr uma defesa da ideologia como elemento formatador das relações sociais, ao mesmo tempo em que as reflete. No comunismo marciano inexistem quaisquer divisões do trabalho, seja social ou sexual. Como veremos posteriormente no Capítulo 3, Bogdánov extrapola essa indiferenciação mesmo para os corpos físicos. A inexistência de gênero na língua mariana reflete ideologicamente a igualdade sexual efetiva de sua sociedade.

Com o incremento da experiência, a luta contra a natureza se torna mais complexa e diversificada, estimulando o desenvolvimento do trabalho coletivo. O papel organizativo do trabalho acaba por cair nas mãos de determinados indivíduos, visto pela coletividade como mais aptos para prover a sobrevivência da comunidade. Esses indivíduos se tornam "organizadores", cujas energias se dirigem à organização do trabalho social. A relação entre implementadores e organizadores constitui para Bogdánov o conceito de "cooperação autoritária" (Bogdanov, 2016 [1913] : 29). A cooperação autoritária dá origem à primeira forma de ligação permanente entre os fenômenos, a causalidade autoritária:

"Seguindo o processo de trabalho, no qual a ação do organizador produz um efeito no implementador, os homens passaram a ver cada sequência estável de fatos na natureza e entre si de acordo com o mesmo esquema: essa é a forma autoritária de causalidade." (Bogdanov, 2016 [1913] :30)

Autoridade e obediência são vistas a partir da forma autoritária de causalidade como a ordem natural do mundo. Nenhum efeito pode ser 
apreendido sem uma causa, um ato inaugural. Se as ações humanas e das coisas não têm causa aparente, os homens assumem que a causa se encontra ali, oculta dos sentidos: "a metáfora básica de uma ação de comandoprodução contém um entendimento da causalidade que se estende para toda a experiência e para todos os fenômenos" (Bogdanov, 2016 [1913] :33). A partir dessa relação de causalidade todas as coisas adquirem uma duplicidade: a parte que comanda é a "alma"; a parte que carrega as ordens dadas é o "corpo". Essa é a primeira visão de mundo: o animismo universal. Se as coisas parecem inertes e passivas, incapazes de produzir qualquer ação, essas são vistas como a antítese do "espírito", portanto matéria. A matéria se subordina ao espírito da mesma forma que o passivo implementador se subordina ao ativo organizador. A causa é preponderante sobre o efeito. Dessa relação causal seguem-se os espíritos ancestrais e as deidades, causas absolutas para todos os fenômenos observáveis.

Bogdánov ressalta que o animismo, visão de mundo que surge da causalidade autoritária, produzida pela experiência do trabalho coletivo, é a base de todas as visões de mundo dualísticas. A consolidação do sistema de conhecimento autoritário possibilita o desenvolvimento da primeira visão de mundo total: a visão de mundo religiosa, em que todos os fenômenos, causalidades e conhecimentos partem da causa absoluta - a deidade (Bogdanov, 2016 [1913] : 35). Para Bogdánov, o sistema de conhecimento autoritário-religioso se manifesta como uma visão de mundo monística, uma vez que condensa toda a experiência coletiva, da mesma forma que as relações autoritárias de produção condensam toda a vida social (Bogdanov, 2016 [1913] : 40).

Com as transformações das relações sociais - novas técnicas de produção, intensificação da divisão social do trabalho e aumento do contato entre comunidades - Bogdánov enxergou o declínio da visão de mundo religiosa. Essas transformações rompem com o seu caráter monístico, centrado na tradição e no conservadorismo e passam a produzir experiências que já não se enquadram nos limites da tradição autoritária. A ascensão da sociedade de trocas possibilitou o desenvolvimento, paralelamente ao sistema de conhecimento religioso, de uma nova visão de mundo, caracterizada por elementos extra-religiosos e, portanto, seculares. Essa visão de mundo extra-religiosa 
tomou a forma da filosofia e das diversas ciências:

“...Pouco a pouco, o pensamento secular ganhou ascendência na prática cotidiana dos homens e passou a ser considerado o 'reino do conhecimento' por excelência. O pensamento religioso foi desconectado da organização dos sistemas de produção, assumindo assim um caráter diafano, tornando-se o reino da 'verdade'." (Bogdanov, 2016 [1913]: 54)

Para Bogdánov, com a ascensão da burguesia e consequentemente de uma nova forma de visão de mundo, ocorre a cisão entre "verdade" e "conhecimento", elementos que, sob a visão de mundo religiosa, significavam a mesma coisa. O pensamento secular acaba por se tornar o reino do conhecimento, isto é, da reflexão das práticas sociais de produção.

Essa visão de mundo secular estabelece uma nova forma de causalidade: a figura do organizador-ancestral deixa de se manifestar em indivíduos e se incorpora em uma nova classe social, inexistente até então. Tal classe, a burguesia, construirá sua visão de mundo de acordo com sua experiência coletiva - sua relação com o trabalho e a produção - em conformidade com as relações de troca. O resultado disso é a substituição do agente organizador individual, humano ou divino, e sua substituição por uma força abstrata - a necessidade econômica:

"[...] a necessidade econômica governa os homens nas relações de troca: define suas atividades e os resultados dessas. Os homens começam a compreender a ligação de todos os fenômenos por meio de uma nova forma de causalidade. Eles passam a entender que um efeito não se encontra subordinado à sua causa, mas que ambos estão subordinados e ligados pela necessidade. Essa necessidade não tem uma mídia concreta e real: é somente necessidade. Essa é a forma abstrata de causalidade peculiar à sociedade de trocas." (Bogdanov, 2016 [1913]:55)

Bogdánov enxergou na visão de mundo abstrata, típica da sociedade de trocas, uma cadeia infinita de causas e efeitos, cujo sequenciamento era governado pela necessidade lógica ou natural. A nova forma de causalidade possibilita que os homens organizem seu sistema de conhecimento de forma a explicar o caos produzido pela produção privada dos indivíduos e sua 
consequente alienação da experiência social total. É importante ressaltar que Bogdánov atentou para o fato de que ambas as visões de mundo coexistem na experiência presente, mantidas em um eterno confronto sem solução: se a visão de mundo abstrata reifica a experiência do trabalho e faz que os produtores se confrontem com sua própria força de trabalho, a visão de mundo autoritária se faz presente nas fábricas e escolas. A cada nível organizacional da experiência, encontramos tendências entre essas duas formas de visão de mundo em constante conflito (Bogdanov, 2016 [1913] : 58).

As visões de mundo de Bogdánov são formas organizacionais do conhecimento produzidas e que refletem os sistemas de produção (trabalho social), os quais, por sua vez, são por elas reforçados. Cada visão de mundo tem suas raízes na prática laboral humana e reflete relações de causalidade que servem como modelos para a organização do conhecimento, ao possibilitar a correlação entre os diversos elementos adquiridos pela experiência total e que se mostram efetivos na luta contra a natureza. As noções de causalidade permitem que se vislumbrem as conexões entre o pensamento e o sistema de produção ao qual ele serve. Esta introdução, bastante longa, é fundamental para entender o projeto de Bogdánov. O autor propõe que a história do pensamento, operada pelo desenvolvimento das noções de causalidade, não se encerra com a visão de mundo abstrata, característica do mundo burguês. Ao contrário, uma nova classe social nasceu com a maquinofatura e, com ela, uma nova forma de causalidade passa a ser gestada: a classe operária e a visão de mundo do labor.

\subsubsection{O que é materialismo?}

"Natureza é como a humanidade chama o infindável campo de sua experiência laboral" (Bogdanov, 2016 [1913] :58). Com essas palavras Bogdánov inicia sua análise sobre o trabalho e seus objetos, a partir dos quais o autor tece sua definição de "matéria". Bogdánov define trabalho social como a atividade total da sociedade, interconectada através de todas as gerações. Por meio do trabalho a humanidade altera as correlações de determinados elementos na natureza de forma a fazê-los atender às necessidades e desejos humanos: 
"acima de tudo, o trabalho organiza o mundo para a humanidade" (Bogdanov, 2016 [1913] : 62).

Trabalho para Bogdánov é sinônimo de esforço e esforço pressupõe resistência. Natureza, objeto de todo o esforço humano, é, portanto, o reino da resistência. O autor tomou emprestado da mecânica clássica sua definição de matéria. Matéria é tudo aquilo que produz resistência ao esforço empreendido. Portanto o reino da natureza é o reino da matéria. É fundamental entender aqui que "matéria" para Bogdánov é uma abstração, uma metáfora para designar tudo aquilo que resiste ao esforço humano. Para ele, não há atividade sem resistência e a matéria, enquanto entidade que resiste, não pode ser concebida sem referência à atividade da qual resiste. Se trabalho significa a prática coletiva da humanidade, matéria é a soma das resistências a essa atividade total. A matéria se correlaciona com o trabalho social e expressa resistência à atividade social: "[...] matéria é a oposição socialmente válida aos esforços humanos, um objeto do trabalho coletivo" (Bogdanov, 2016 [1913] : 62).

Bogdánov credita a Marx sua definição de matéria: “[...] apenas Marx foi capaz de compreender que a matéria é o objeto da produção - sua essência. É por isso que Marx usou o termo "materialismo" para se referir à sua doutrina filosófico-social, na qual descobriu na produção a base e causa do desenvolvimento social" (Bogdanov, 2016 [1913]:64). No processo de organizar os elementos do mundo, a humanidade se depara com a materialidade da natureza, com sua resistência aos esforços organizativos do trabalho. Bogdánov define com essa apresentação sua definição de materialismo ${ }^{4}$.

Partindo da premissa de que o trabalho, para organizar os elementos da natureza, necessita antes ser organizado, Bogdánov apresentou dois níveis de organização da atividade laboral: um nível técnico e direto, que atua diretamente sobre o reino da matéria; e um nível organizacional, cuja tarefa é produzir ideias, conceitos e normas. Esse último é o reino do espírito, da

4 Embora não apareça em "Estrela Vermelha", Marx será exaustivamente representado por Bogdánov em sua sequência "Engenheiro Menni" de 1913. Nessa obra, Bogdánov representa Marx na figura do grande filósofo e economista Xarma, pai do socialismo marciano, que previu o processo de desintegração do campesinato e o desastre ecológico proporcionado pelas relações caóticas de produção capitalistas. Xarma forneceu os fundamentos para a constituição da visão de mundo operária, base ideológica do comunismo marciano (Bogdanov, 1984 [1908] : 168) 
ideologia. O trabalho direto atua no mundo físico, enquanto os processos ideológicos atuam em sua organização. Tais níveis, de acordo com Bogdánov, não se encontram subordinados, mas atuam correlacionalmente, cabendo à ideologia atender as demandas que surgem a partir do trabalho técnico. Também não há diferenciação entre eles: enquanto o trabalho técnico encontra resistência na natureza, o trabalho ideológico encontra resistência na natureza laboral dos homens (Bogdanov, 2016 [1913] : 83). Para Bogdánov a esfera do espírito é também material. Ainda que pertencente à esfera da consciência, ela existe enquanto atividade organizativa do trabalho social. Uma vez que a humanidade encontra-se subsumida ao reino da matéria, também assim se dá com o reino da experiência da qual faz parte a consciência humana.

De acordo com Bogdánov, materialistas e idealistas operam por meio do método substitutivo. Tal método permite que a experiência seja complementada por meio de significados similares que contradizem a natureza daquilo que é observado. Toda a natureza não-material e não-espiritual é substituída no processo de organização do conhecimento por um atributo material ou espiritual, que ressignifica o elemento da natureza de acordo com a visão filosófica pertinente. Bogdánov oferece diversos exemplos do método substitutivo que acredita ser elementares:

"[...] alguém diz para você: 'pegue tal livro. É brilhantemente escrito e cheio de sabedoria e pensamentos profundos'. Nem você ou seu interlocutor percebem que o livro-em-si sobre o qual conversam é substituído pela segunda proposição, algo completamente diferente. Um livro é um material complexo. É feito de papel, tinta tipográfica, cola etc. Em todas essas coisas você não vai achar sabedoria ou pensamentos profundos, seja através da análise química ou com a ajuda de um microscópio. As características em questão estão relacionadas ao complexo intelectual associado à escrita e leitura do livro, mas você calmamente substitui o complexo material pelo complexo intelectual ou, de outra forma, aceita que são a mesma coisa." (Bogdanov, 2016 [1913]: 86)

Bogdánov clama que o método substitutivo é fundamental para que os homens consigam se comunicar e explicar o sentido e a correspondência de suas ações. Essa forma elementar de substituição, de acordo com Bogdánov, é eventualmente carregada para as esferas da experiência, com o objetivo 
de fornecer compreensão do mundo. Materialistas e idealistas, mesmo ao realizar práticas de substituição extremamente complexas, não fazem nada qualitativamente diferente de seus ascendentes: "[...] pegar um objeto $e$ efetivamente transformá-lo em outra coisa, enquanto admite, ao mesmo tempo, suas diferenças essenciais" (Bogdanov, 2016 [1913] : 88).

O materialista afirma que tudo aquilo que não é matéria é uma manifestação, sua propriedade e atributo; aqui Bogdánov utiliza como exemplo a definição apresentada por Plekhánov: "pensamento é uma manifestação dos processos neurais do cérebro, ou, pensamento é processo neural" (Plekhánov, 1907, apud Bogdanov 2016 [1913] : 92). Bogdánov defende que não há nada real que autorize tal substituição: é uma escolha meramente arbitrária. Similarmente, o idealista opera da mesma forma ao determinar arbitrariamente que todas as sensações, tudo aquilo que é substancial, acaba sendo uma manifestação do pensamento. Cabe, porém, ressaltar que Bogdánov, a despeito de suas críticas, não iguala em valor as substituições materialista e individualista. O materialismo, ainda que vulnerável à mesma fetichização que recai sobre o idealismo, parte das relações objetivas que compõem o reino da experiência e, por isso, é organizativamente superior.

A insistente incapacidade demonstrada pela filosofia em reconhecer a mediação entre matéria e espírito por meio da experiência coletiva tem sua origem, de acordo com Bogdánov, naquilo que ele denomina "fetichismo abstrato". Bogdánov, diferentemente do marxismo ortodoxo de sua época, concede à teoria do fetiche uma posição central na obra de Marx e a utiliza para explicar não apenas os problemas epistemológicos apresentados acima, mas a própria resiliência do capitalismo e da sociedade de trocas.

O desenvolvimento de conceitos absolutos - matéria e ideia - parte para além do reino da experiência humana na medida em que pressupõe a existência de coisas-em-si desconectadas da atividade social e de seus objetos. Bogdánov defende que a substituição materialista/idealista seria impossível caso fosse reconhecida a interdependência dos dois conceitos à própria atividade humana: "uma ideia que é objetivamente o resultado de atividade social passada, e que se torna ferramenta dessa mesma atividade social, é apresentada como algo independente, apartado de sua origem" (Bogdanov, 2016 [1913]:93). 
O fetichismo abstrato se eleva da própria organização da sociedade de trocas. Essencialmente atomizante, o fetichismo abstrato faz com que os indivíduos percam a consciência de pertencimento ao coletivo. Isso decorre, de acordo com Bogdánov, devido à fragmentação social, à independência formal de vários aspectos da produção, à competição do mercado e à luta econômica em sua generalidade. Sob a influência do fetichismo, "[...] a atividade social deixa de existir para o indivíduo e é estilhaçada em átomos de atividade individual" (Bogdanov, 2016 [1913]:96). Se o pensamento e a matéria são objetos da atividade social, sua fragmentação em uma miríade de atividades falsamente individuais torna inevitável que os homens vejam esses elementos da experiência como coisas-me-si, independentes da própria experiência que as produz. Por meio do sociomorfismo, isto é, da reflexão no pensamento das atividades sociais produtivas, Bogdánov defende que o processo de objetificação do trabalho humano, elemento organizativo fundamental da sociedade de trocas acaba por "coisificar" a própria consciência, difundindo-se por todos os níveis da experiência total. A prática coletiva não deixa de existir pois é condição ontológica da humanidade, mas acaba mascarada pela pela luta econômica, oculta pelos interesses e empreendimentos privados e se torna inacessível à consciência dos indivíduos.

Bogdánov argumenta que sua perspectiva descende das teses de Marx sobre Feuerbach. Ele diz que Marx provou ali o caráter contemplativo de qualquer filosofia que trate a matéria de forma apartada da atividade humana. Marx rejeita qualquer forma passiva de filosofia enquanto sistema de conhecimento e clama por um materialismo ativo, que compreenda o conceito da matéria como objeto imanente à atividade social humana (Bogdanov, 2016 [1913] : 103).

Os produtos da filosofia idealista são abstratos e desprovidos de conteúdo quando apartados da experiência total; os produtos do materialismo, por outro lado, carregam em si a marca das relações produtivas, mas são incapazes de se desprender do individualismo da sociedade de trocas, e por isso conseguem apreender apenas uma pequena parte do mundo da resistência - o objeto da produção. Bogdánov defende uma nova linha filosófica que supere todas as formas de materialismo ao resgatar a conexão relacional entre ideia e 
matéria como elementos da experiência, unificando-as em uma nova forma de monismo.

Na sociedade marciana, que superou a condição fetichista das relações capitalistas, não há filosofia. A cisão entre as abordagens materialista e idealista perdem a razão de ser sob a experiência unificada monisticamente. A filosofia, enquanto ferramenta de orientação dos homens em sua relação com a experiência, é absorvida pela ciência enquanto forma organizativamente superior de orientação. Netti traduz essa posição de Bogdánov em "Estrela Vermelha":

"Todos os sistemas de filosofia são, é claro, manifestações de uma cognição imperfeita e fragmentada e refletem um nível deficiente de desenvolvimento científico. Eles representam tentativas de prover uma descrição uniforme do Ser preenchendo as lacunas da experiência científica com especulações. Eventualmente portanto, a filosofia será eliminada da Terra, assim como foi eliminada entre nós pelo monismo da ciência." (Bogdanov, 1984 [1908]: 118)

Este monismo da ciência emergirá, de acordo com Bogdánov, da emergência da "visão de mundo do labor", que unificaria os trabalhos técnicos e ideológicos como aspectos inseparáveis da atividade coletiva, superando a irracionalidade própria do modo de produção burguês e a teia infindável de reificações que tal irracionalidade difunde por todos os níveis da experiência, expressa pela causalidade caótica que aparta os indivíduos da experiência social.

\subsubsection{Empiriomonismo e a Ciência do Futuro}

Nesta última parte procuraremos delinear a proposta apresentada por Bogdánov para superar as relações fetichistas produzidas pela causalidade infinita da sociedade de trocas e prover uma solução à crise pela qual passa a filosofia, a seu ver, incapaz de servir como ferramenta de orientação para harmonizar os saberes organizativos dos homens, uma vez que ela mesma encontra-se apartada da experiência social por efeito do fetichismo abstrato. Ainda que Bogdánov trate dessas questões em capítulos separados, acreditamos ser metodologicamente possível e mesmo desejável condensá-los em uma única 
apresentação, uma vez que os capítulos "Empiriomonismo" e "Ciência do Futuro" partem das críticas e considerações feitas anteriormente para propor uma solução aos problemas levantados. Ambos são redigidos por Bogdánov como o ponto máximo de sua obra, tornando os capítulos anteriores prolegômenos a suas assertivas finais. Passemos então à análise de suas prescrições.

O empiriomonismo é a "filosofia da vivência" que dá título à obra. Bogdánov aborda sua filosofia de duas maneiras distintas: em primeiro lugar, como uma solução para a crise da filosofia; em segundo lugar, como uma nova forma de visão de mundo, diferente das formas predecessoras. Para Bogdánov o empiriomonismo parte de uma perspectiva básica daquilo que a filosofia deveria ser: uma ferramenta de orientação. Tal orientação representa a "perspectiva laboral" que demanda uma nova visão de mundo, capaz de refletir e reforçar suas ambições: a unificação da totalidade do trabalho em um único sistema de organização do conhecimento. Marx toma a totalidade do trabalho social como seu ponto de partida para explicar os processos sociais. Bogdánov se esforça em apresentar o empiriomonismo como herdeiro do materialismo proposto por Marx, em contraposição às formas contemplativas de materialismo fetichizadas, defendidas pelos marxistas que lhe eram contemporâneos. O autor vê seu materialismo a partir da perspectiva proposta por Marx, julgando-o como uma visão de mundo verdadeiramente ativa. Bogdánov credita a Marx a fundação do "ponto de vista laboral" do qual parte sua própria filosofia.

Jensen (1978:12) atenta para o fato de que a maioria dos escolásticos que se debruçaram sobre a obra de Bogdánov ignoraram o conceito do "ponto de vista laboral". Tal princípio é fundamental em seu pensamento pois orienta todas as suas reflexões em torno das atividades objetivas de produção, vinculando a essas o próprio propósito da filosofia, ao mesmo tempo em que serve como alicerce para a construção de uma filosofia que se propõe diferente a todas as formas que a antecederam. Bogdánov afirma partir do mesmo ponto que Marx na aplicação do ponto de vista laboral e ir além, de forma a estabelecer as bases para uma nova visão de mundo. 


\section{Causalidade socio-laboral}

Bogdánov inicia sua apresentação final determinando que seu ponto de partida é a perspectiva laboral, isto é, a totalidade da produção social. A partir daí o autor propõe a construção de uma "visão de mundo laboral". Como vimos anteriormente, as "visões de mundo" são complexos organizativos da experiência total que refletem e reforçam os sistemas de causalidade que surgem a partir das condições objetivas de produção. A construção da visão de mundo laboral, portanto, deve se iniciar com a busca de uma nova noção de causalidade, a causalidade sócio-laboral.

Tal causalidade, de acordo com Bogdánov, já existe na atividade do proletariado: "[...] o proletariado rejeita as causalidades autoritárias e abstratas como fetichistas. Isso acontece porque na experiência da classe trabalhadora já existem novas relações práticas que diferem de tudo que já existiu antes" (Bogdanov, 2016 [1913] :268). O modelo para uma nova causalidade deve ser visto por aqueles que mantêm a perspectiva laboral como seu ponto de partida. Bogdánov coloca no centro da relação ativa entre a humanidade e o mundo a classe operária, situada no centro da produção capitalista. Sua centralidade na produção industrial maquinofatureira é o pressuposto fundamental para compreender - e mudar - o mundo à sua vontade. Essa condição e potencialidade de transformação pela vontade é reflexo da transformação do mundo executada pela maquinofatura, cuja existência é indissociável da existência da classe operária.

Bogdánov defende que a essência da maquinofatura reside na "transformação sistemática de esforços ou, em termos científicos, na transformação da energia" (Bogdanov, 2016 [1913] :269). A maquinofatura transforma o mundo ao converter diferentes formas de energia - térmica, química, elétrica entre si, de forma que tais forças naturais sirvam como fonte para as forças mecânicas de produção. Essa constatação gera em seu pensamento uma nova perspectiva, uma nova forma de causalidade: "[...] cada processo no mundo é a causa possível para outro processo. [...] Se o fenômeno B resulta do fenômeno $A$, esse último é transformado no primeiro da mesma forma que a energia do carvão ou de uma catarata é transformada em trabalho 
das máquinas" (Bogdanov, 2016 [1913] : 270). Nesse caso, um fenômeno não deve ser visto como a causa ou efeito de outro fenômeno por qualquer forma de necessidade abstrata ou autoritária. Apenas a vontade humana tem a habilidade de realizar tais transformações. A maquinofatura e o avanço da técnica permitiram aos homens, pela primeira vez, controlar conscientemente a interação entre os fenômenos.

Bogdánov compara essa noção de causalidade com as formas causais precedentes: autoritária e abstrata. Na causalidade autoritária, a causa predomina sobre o efeito como algo ativo; na causalidade abstrata, o efeito segue a causa, determinada pelas necessidades econômicas; para a causalidade sócio-laboral, a causa é mera fonte técnica do efeito e ambos podem ser intercambiados por meio da vontade e da técnica.

Essa definição é fundamental para entendermos as bases do empiriomonismo. Na forma de causalidade laboral, o homem deixa de ser objeto de forças que atuam fora de sua experiência, seja de entidade invisíveis, seja de necessidades econômicas. O desenvolvimento da máquina permite que o homem esteja no centro dos processos de causalidade, controlando por meio da vontade e da consciência as infinitas possibilidades de transformação dos fenômenos. Ele já não sofre os efeitos das formas de causalidade. Ele se torna o regulador de todos os processos causais. Ao se tornar a causa de todos os fenômenos, o homem adquire poder infinito sobre o mundo que resiste à sua atividade.

\section{Elementos da Experiência}

Como vimos anteriormente, Bogdánov define experiência como a soma de todos os esforços humanos e natureza como a resistência a esses esforços. Ao ser organizada pelos sistemas de conhecimento, a experiência, i.e. a totalidade do mundo onde atua o esforço humano, é dividida em elementos componentes. Tais elementos não são coisas absolutas, partículas indivisíveis e apriorísticas: são os homens que concedem, a partir da práxis social historicamente determinada, significados a esses elementos, de acordo com as demandas estabelecidas pela luta contra a natureza - o reino da resistência. 
É através do trabalho que o homem quebra a experiência em componentes de acordo com as necessidades produtivas. O desenvolvimento técnico das forças produtivas permite novas formas de interação entre os elementos, produzindo novas formas de compreensão do mundo. Bogdanov (2016 [1913] :276) define os elementos como a soma de esforço humano dirigido contra o reino da resistência de acordo com a necessidade social. Cada elemento é um produto do esforço desse trabalho, um "cristal" de trabalho. Esses condensam, portanto, uma quantidade determinada de um determinado tipo de esforço empreendido contra uma determinada quantidade de um determinado tipo de resistência. A experiência é a soma de todos esses cristais de trabalho.

Interessante notar que Marx define Valor como uma "medida de tempo de trabalho cristalizado na mercadoria" (Marx, 2013:116). O Valor é a forma quantitativa do trabalho abstrato, indiferenciado, desprovido de suas qualidades sensíveis e que serve de denominador comum para a troca entre valores de uso. Ao abstrair-se do trabalho e de seu fruto, suas características úteis, desaparecem também as formas concretas desses trabalhos, restando apenas uma "objetividade fantasmagórica, uma geleia de trabalho humano indiferenciado" (Marx, 2013:117). A transformação do trabalho concreto em trabalho abstrato, i.e. em uma relação social, corresponde, no empiriomonismo de Bogdánov, na constituição dos elementos a partir do reino da experiência, que existe apenas enquanto a soma dos trabalhos sociais. A partir da forma cristalizada da quantidade de trabalho socialmente empreendido, Marx e Bogdánov elaboram respectivamente seus conceitos: Valor e elemento.

Essa objetividade fantasmagórica proposta por Marx nos serve como chave interpretativa para entender a natureza dos elementos na teoria empiriomonista: assim como as mercadorias prenhas de valor adquirem uma "natureza sensível-suprassensivel" (Marx, 2013 : 134), os elementos de Bogdánov não são sensuais ou materiais. Eles carregam as duas naturezas, pois existem no mundo físico ao mesmo tempo em que são criados na consciência pela atividade do trabalho e, a partir dali, reforçam e estabelecem novas relações com a atividade do trabalho social. Ao surgirem a partir da atividade produtiva, os elementos são então combinados pelos homens em um número ilimitado de formas com o objetivo de atender as demandas do esforço humano. Com o 
desenvolvimento da visão de mundo laboral, determinada pela causalidade sócio-laboral, cada fenômeno pode ser a causa de outro fenômeno. Elementos da experiência podem ser convertidos em outros elementos. Não há pontos de partida ou de chegada na relação causal da maquinofatura, e portanto não há formas fundamentais na causalidade do labor.

\section{Objetividade}

Bogdánov afirma ser a discriminação de elementos uma questão meramente organizativa. Como organização, o autor entende ser a estruturação sistemática da experiência operada pelo homem para atingir seus fins (Bogdanov, 2016 [1913] : 280). Essa organização atua em níveis de complexidade diversos, partindo das formas mais simples em direção às mais complexas: a natureza inorgânica, a vida, os indivíduos e a coletividade humana. Tais níveis se relacionam com as dimensões físicas e psíquicas da experiência. Bogdánov argumenta que a dimensão física e psíquica não são qualitativamente diferentes - ambas são expressão da experiência organizada. O que diferencia tais dimensões é o nível de organização dessas experiências. Para Bogdánov a dimensão física se caracteriza pela experiência socialmente organizada. Por outro lado, a dimensão psíquica é a organização individual da experiência. Bogdánov nos fornece um exemplo didático:

“...Considere um machado. Ele pode existir tanto como uma ferramenta real para uso na produção como uma representação mental. $O$ machado é um complexo físico ou mental. Cada um reside em um nivel diferente da experiência organizada. No entanto compartilham os mesmos elementos, exibem as mesmas propriedades na mesma proporção. O que dá fisicalidade ao machado é o fato de que ele existe como um complexo definido de elementos, relacionado em formas definidas com a experiência de todos os homens. Isso não quer dizer que o machado físico é idêntico a todos os homens. Afinal, alguns homens são médicos, químicos, outros são lenhadores. Enquanto o machado não é idêntico a todos, as diferenças são mais complementares que contraditórias." (Bogdanov, 2016 [1913] : 282)

Bogdánov define um complexo físico como aquele que pertence "à experiência socialmente determinada e compartilhada pelos homens" (Bogdanov, 
2016 [1913] : 283). Já os complexos psíquicos se limitam à experiência individualmente organizada. A característica distintiva da experiência física de Bogdánov é sua objetividade. Para o autor, objetividade e fisicalidade são a mesma coisa. Objetivo é tudo aquilo que é socialmente organizado. Assim a representação psíquica do machado não pode ser objetiva, já que não pode ser socialmente verificada. Logo ela é subjetiva.

Note-se que, para Bogdánov, os complexos objetivos não podem existir apartados dos homens. Eles são socialmente criados e mudam de acordo com as necessidades coletivas estabelecidas. A natureza é não-objetiva e seu status só muda quando se relaciona, enquanto resistência, com a atividade humana. As leis naturais são complexos físicos construídos a partir de elementos produzidos pela atividade social, como ferramentas de mensuração, sensores e medidas. Para Bogdánov, se a gravidade existia antes do homem, a lei da gravidade é parte da experiência humana.

Em determinado trecho da obra, Bogdánov dirige um ataque ao "materialismo vulgar" de Plekhánov. Bogdánov acusa o fundador do marxismo russo de adotar uma postura "não-dialética, não-histórica e não-marxista" ao negar a condicionalidade social do mundo objetivo. Para ele, sua definição de objetividade se encontrava plenamente em acordo com as ideias de Marx, que se referiu ao mundo objetivo como o mundo da prática social. Objetividade não é de forma alguma absoluta e eterna, mas algo socialmente produzido e dependente das relações laborais e sociais (Bogdanov, 2016 [1913] :285). Para Bogdánov, o objetivo - aquilo que é dotado de fisicalidade - é a forma mais complexa de organização da experiência e a que melhor serve a coletividade ao objetivar o mundo por meio da atividade laboral coletiva.

\section{Sociomorfismo}

Bogdánov defende que a experiência é organizada a partir de modelos cognitivos. Tais modelos incluem desde palavras, leis, noções de causalidade, instituições, até teorias científicas. Essas também se organizam por níveis qualitativos: a linguagem é sua forma mais básica; as noções casuais são as formas mais importantes; as teorias científicas as mais úteis. Tais modelos 
refletem e reforçam as relações de produção que as geram (Bogdanov, 2016 [1913] : 291). A esses modelos Bogdánov denomina "sociomorfismo" e a lei pelo qual tais modelos procedem é a "lei do sociomorfismo".

Os modelos cognitivos não derivam tão somente da prática sócio-laboral, i.e, da atuação direta dos homens sobre a natureza. Eles também se desenvolvem a partir de modelos técnicos e das relações econômicas. As transferências desses modelos do mundo prático ao cognitivo passa pela aplicação de sofisticados métodos, por meio de simplificações, combinações ou mesmo complicações. No entanto, o que nos importa aqui é a ideia central do conceito, ou seja: os modelos cognitivos não apenas surgem a partir dos métodos práticos, mas os reforçam (Bogdanov, 2016 [1913] : 293). Bogdánov afirma ser o papel dos filósofos se utilizar da lei do sociomorfismo e, a partir da perspectiva laboral, aplicar esses modelos cognitivos de forma a organizar a experiência que atenda às necessidades produtivas, econômicas e sociais de sua classe. O filósofo é o criador definitivo do pensamento, uma vez que se encontra na posição original de pensar as relações de produção que originam o próprio pensamento.

\section{Substituição}

Nessa seção, Bogdánov apresenta sua proposta para organizar toda a experiência em um sistema unificado, livre de rupturas e contradições. Isso passa, primeiramente, por reconhecer o sociomorfismo como o método final de organização dos modelos de cogniff̧̧̃̃o. No entanto é necessário, de acordo com Bogdánov, desenvolver uma ferramenta cognitiva, derivada da causalidade laboral, que permita unir todos os modelos cognitivos sociomórficos. A esse método o autor denomina "substituição universal".

Como vimos anteriormente, Bogdánov trata o método de substituição como uma forma elementar do processo de pensamento. No método de substituição encontramos a relação cognitiva entre o significante e o significado, em que um é substituído por outro, e este, por sua vez, é produzido pela atividade humana. Cada ato de substituição atende ao funcionamento de um modelo sociomórfico que opera a organização dos elementos correlacionados. 
Cada substituição torna um sociomorfismo simples, de pouco impacto na consciência e na atividade laboral, em um sociomorfismo mais complexo e portanto mais útil para a atividade produtiva (Bogdanov, 2016 [1913] : 301). Esse processo se estende por todos os níveis organizacionais da experiência. No entanto, enquanto a substituição opera de forma fetichizada na sociedade de trocas, sob a causalidade do labor, tal método produzirá uma nova correlação entre os modelos cognitivos.

Uma vez que a causalidade laboral se caracteriza pela transformação dos fenômenos sem qualquer distinção entre causa e efeito, podemos concluir que todo e qualquer fenômeno pode ser substituído por quaisquer outros fenômenos. A substituição adquire um caráter universal na medida em que possibilita a troca entre modelos cognitivos diversos, utilizados em todas as esferas da experiência. Todos os métodos científicos, apartados pela superespecialização decorrente do fetichismo abstrato, poderiam ser substituídos por um único método, da mesma maneira que um fenômeno pode ser substituído por qualquer outro fenômeno. A ascensão da visão de mundo laboral traz consigo a ruptura de todas as reificações, de todos os fetichismos. Matéria e ideia se tornam uma coisa só, níveis diferentes da experiência organizada e, por meio da substituição universal, tornam-se intercambiáveis. Aliada à causalidade laboral, a substituição universal torna possível, de acordo com Bogdánov, a unificação de toda a experiência em um continuum desprovido de rupturas, um sistema monístico da experiência.

\section{A Visão de Mundo Empiriomonística}

"A substituição universal permite, pela primeira vez, a elaboração de uma visão holística e coerente do mundo, livre das descontinuidades e contradições cognitivas" (Bogdanov, 2016 [1913] : 307). Bogdánov, no capítulo final de sua obra, apresenta ao leitor o ponto de chegada da perspectiva do labor, um retrato do mundo possível através da unificação de toda a experiência. Esse é um mundo apreendido pela consciência como "uma série infinita de atividades organizativas, que resulta por sua vez em uma série infinita de níveis de organização da experiência, integralmente correlacionadas umas às 
outras" (Bogdanov, 2016 [1913] : 307).

A cada momento, o coletivo humano faz avançar cada vez mais as fronteiras da experiência através da vontade coletiva que atua em resposta às suas necessidades. Em seu nível mais avançado, representado pelo humano coletivo, a vida não apenas se perpetua, mas se expande e reconstrói o mundo de acordo com sua vontade. O empiriomonismo possibilita que o homem refaça o mundo à sua imagem e semelhança, uma vez que esse já não se encontra sob o jugo de quaisquer formas abstratas de causalidade. A humanidade passa a determinar por sua vontade tudo aquilo que é causa e efeito. Isso a torna criadora da realidade (experiência) e de seus componentes (os elementos), entidades que despertam de acordo com suas necessidades a partir de sua vontade.

O empiriomonismo intenciona ser a visão de mundo responsável pela libertação do homem de todas as limitações externas. Na realização de seu sistema monístico, desaparecem as leis naturais e as necessidades causais. Mesmo a individualidade desaparece, subsumida no coletivo humano. O ego, de acordo com Bogdánov, existe apenas como cisão entre os níveis de experiência físico-objetivo e psíquico-subjetivo. A substituição universal torna tal separação irrelevante. O homem resgata sua relação com o mundo social, rompido pelo fetichismo da sociedade de trocas. Bogdánov apresenta o empiriomonismo como a solução para a crise da filosofia, substituindoa como ferramenta de orientação da ação humana. O empiriomonismo é científico uma vez que se baseia na experiência coletiva da humanidade em sua luta contra a natureza. A unificação de toda a experiência também faz desaparecer quaisquer formas de divisão social do trabalho: cada trabalhador é um cientista, uma vez que desaparecem as diferenciações entre trabalho prático e ideológico, fruto da automatização dos meios de produção e da ascensão do proletariado como a classe-mestre da maquinofatura.

Não podemos deixar de concluir que o pensamento de Bogdánov atua, mesmo que tortuosamente, sob o princípio dialético de negação da negação. O comunismo para Bogdánov passa pela constituição de uma sociedade altamente tecnocrática, em que toda a experiência se encontra subsumida a uma forma monística de visão de mundo. Essa unificação de todos os níveis 
da experiência torna todo o trabalho indiferenciável e faz desaparecer todas as formas de divisão social do trabalho. A forma tecnocrática de comunismo se assemelha às próprias formas de organizações sociais primevas descritas pelo autor, caracterizadas pela forma monística de visão de mundo e inexistência de dualidades na expressão da experiência. Esse monismo é rompido pelo advento da sociedade de troca, a qual produz novas formas de causalidade que esgarçam a relação entre os indivíduos e o coletivo. Bogdánov acaba propondo ser o modo de produção capitalista e sua lógica irracional a antítese dos monismos primevos. Assim, o comunismo se mostra a superação desse processo, reafirmando o caráter monístico da experiência em sua forma mais rica.

Para concluir, devemos ressaltar que Bogdánov enxergou no desenvolvimento da visão de mundo do labor a pré-condição para o sucesso da revolução. Bogdánov rejeitou a partir de sua filosofia a divisão entre prioridades políticas ou culturais. Ambas são expressões da experiência organizada pela cognição a partir da leitura fetichizada das relações objetivas de labor. Para ele, a partir das reflexões aqui apresentadas, tornara-se fundamental o desenvolvimento da "Ciência Universal Organizacional", que viria a unificar os métodos de todas as ciências, de todas as filosofias. A partir da leitura de sua obra é possível contextualizar as razões que fazem Bogdánov se afastar cada vez mais do cenário político russo e se dedicar com enorme intensidade às questões culturais e científicas. Ainda que praticamente esquecido enquanto uma releitura do marxismo de seu tempo, o empiriomonismo bogdanoviano pode ser visto como a introdução dos futuros projetos de Bogdánov e que impactarão com grande intensidade a vida científica e cultural da Rússia Soviética em seus primeiros anos: a Tektologia e o Proletkult. 


\section{3 \\ Narodistas, marxistas e \\ marcianos: Enclaves Utópicos e Espaços Desalienados}

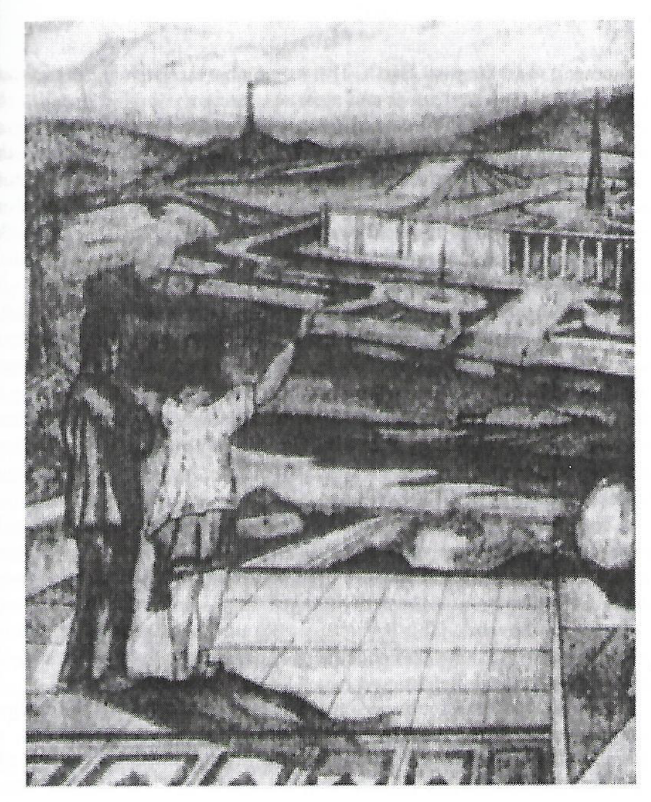

"E assim eu digo que entre as muitas coisas que devemos transformar em Marte, nosso ser e nossa realidade social devem figurar entre elas. Nós devemos terraformar não somente Marte, mas a nós mesmos."

Arkady Bogdanov, 2030 (Robinson, 1993: 89) 
Fredric Jameson classifica como "enclave utópico" o caráter totalizante do espaço utópico. Esse "enclave" opera dialeticamente a partir do estranhamento cognitivo que a literatura utópica tenta gestar enquanto particularidade produzida no espaço real, em sua condição de contexto, ao mesmo tempo em que opera a universalidade de uma condição desalienada na sua condição de texto (Jameson, 2005 : 16). Esse processo cria a partir do tecido social existente um espaço virtual, extrapolado no tempo e espaço e que serve como tela para o experimento utópico, daí o conceito de enclave. Uma vez extrapolado de seu contexto o enclave utópico expressa sua relação dialética com o objeto da crítica: por um lado emana fraqueza política ao se encontrar para além do alcance de relações socialmente determinadas; por outro lado cria um espaço onde novas formas de experiência podem ser exercitadas e elaboradas (Jameson, 2005:16). Stites (1989:199) defende que essa extrapolação pode ser temporal (uma forma comum na literatura distópica cyberpunk ou mesmo em obras como "Fundação", de Isaac Asimov e "A cidade e as estrelas", de Arthur C. Clarke) ou espacial, como as literaturas de viagem modernas dos séculos XVI e XVII ("A cidade e o sol", de Tommaso Campanella, e "Utopia", de Thomas More, são exemplos canônicos dessa categoria). No entanto, é forçoso constatar que rarame nte a tipificação de categorias estanques consegue dar conta da multiplicidade de mediações que intersectam o texto ao seu contexto e, no afã de encaixar as obras nesses limites, acaba produzindo mais exceções que regras. Stites tenta classificar "Estrela Vermelha" como uma distopia temporal, uma vez que a revolução descrita na obra havia acontecido três séculos antes.

A despeito do que conclui Richard Stites, "Estrela Vermelha" não pode ser classificada como uma utopia temporal. Se é certo que seu motor narrativo - a revolução - encontra-se de fato deslocado no passado, Bogdánov assim o faz apenas para demonstrar que a construção do comunismo levará tempo, muito mais do que acreditou Trotski em sua crítica à arte proletária (Trotski, 1969 : 166). "Estrela Vermelha", em sua estrutura textual, é uma narrativa de viagem, em que conhecemos o enclave utópico por meio das observações de um viajante. Esse enclave encontra-se apartado do mundo, é fechado em si mesmo, uma sala sem janelas. No caso de "Estrela Vermelha", a natureza 
monádica do enclave possibilita aquilo que Jameson denomina como uma "exploração geográfica do sonhar", cuja forma é por sua vez condicionada pelo surgimento de novas fronteiras da experiência (Jameson, 2005 : 18). Se para More isso se deu pelo agigantamento do mundo na Idade Moderna por meio das navegações, para Bogdánov isso se dá pela iminência da revolução social, que abre a possibilidade de um mundo ignoto.

A construção espacial do enclave não existe para além da experiência histórica na qual está inserida. A utilização de uma obra utópica como documento historiográfico deve sempre manter em vistas que diversas mediações, históricas e concretas, atuam silenciosamente na construção da utopia, muitas vezes ocultas na entrelinha do texto. A utopia não paira no espaço e nem o espaço existe em um vácuo incognoscível. Relações sociais objetivas, sejam elas concretas ou abstratas, operam na ocupação, redimensionamento e realocação dos recursos e acabam por estabelecer limites estruturais que cerceiam a ação possível de transformação, tanto no mundo objetivo que é criticado, quanto no mundo utópico que critica. Pensar a ocupação do espaço em um enclave é também pensar indutivamente a produção pessoal do autor em sua relação com contexto histórico no qual está inserido e suas múltipla determinações.

O Capital, enquanto relação social autonomizada, transforma o espaço de forma a adequá-lo à sua necessidade mais candente: a reprodução ampliada do Valor. Para atender as suas necessidades de produção, circulação e realização, o Capital reduz os espaços, socializa as relações de produção por meio da especialização técnica, concentra a produção em grandes centros urbanos, proletariza a população campesina e realoca os mercados, estimula seguidas revoluções tecnológicas visando à aceleração de seu circuito. Marx já em 1848 se encontrava atento à profunda transformação que a ampliação do Capital produzia sobre o espaço:

"A grande indústria criou o mercado mundial, preparado pela descoberta da América. O mercado mundial acelerou enormemente o desenvolvimento do comércio, da navegação, dos meios de comunicação. (...) A burguesia submeteu o campo à cidade. Criou grandes centros urbanos; aumentou prodigiosamente a população das cidades em relação à dos campos e, com isso, arrancou uma grande parte da 
população do embrutecimento da vida rural. Do mesmo modo que subordinou o campo à cidade, os países bárbaros ou semibárbaros aos países civilizados, subordinou os povos camponeses aos povos burgueses, o Oriente ao Ocidente." (Marx \& Engels, 1998:41, 44)

Ao analisar especificamente esse trecho de "O Manifesto Comunista", Harvey (2001 : 201) aponta que, para além de uma simplificação datada que flerta com o difusionismo ${ }^{1}$, deve-se considerar que o desenvolvimento do capitalismo atua sobre espaços geográficos desiguais, que instam práticas diversas de acumulação e produzem respostas múltiplas a esse processo. Tal relação é dialética no sentido preciso em que o espaço transforma o Capital que se reproduz em sua territorialidade e é por sua vez transformado por esse processo. A lógica alienada de reprodução adquire formas diversas em sua relação mediada com espaços particulares.

O debate com os narodistas já nos anos 1870 mostra que a análise marxiana das particularidades de desenvolvimento do capitalismo em espaços desiguais evoluiu para muito além do difusionismo corretamente apontado por Harvey. Ao questionar a possibilidade de desenvolvimento do socialismo a partir da obshchina sem passar necessariamente por uma fase capitalista, Vera Zasulitch provocou em Marx ricas reflexões sobre as especificidades do desenvolvimento capitalista na periferia do sistema-mundo e colocou em questão o etapismo determinista que se desenvolveu a partir de suas ideias. A questão agrária - que traz em seu bojo debates mais amplos como a questão da transformação do espaço e subsunção do campo em relação à cidade - percorreu décadas de debates entre os socialistas russos e marcou profundamente a nascente social-democracia russa, contribuindo de forma essencial para suas particularidades.

Mészáros (2016:102) nos mostra que a produção alienada do mundo social, expressa na reificação do produtor em sua relação objetivada com o fruto de seu trabalho, parte da decomposição do trabalho - mediação metabólica entre o homem e a natureza - em mediações de segunda ordem ontologicamente contraditórias (trabalho assalariado e propriedade privada) e

\footnotetext{
1 Para fins de esclarecimento tomamos como difusionismo um conjunto de teorias as quais sustentam que o desenvolvimento de determinados artefatos culturais e relações sociais partem de um ponto inicial, geográfica e culturalmente delimitado, e se difundem em outros espaços.
} 
se estende por todas as esferas da atividade humana. Compreender o processo de acumulação do Capital por meio da teoria da alienação nos permite perceber como a transformação do espaço pelo Capital produz um espaço também alienado, marcado por contradições que emergem da desintegração dos conteúdos particulares da vida social russa em uma forma universal, "estranha" para uma geração de narodistas e "inevitável" para uma geração de social-democratas.

Já sabemos que Bogdánov concede à teoria da alienação espaço central em sua obra. No entanto saber desse fato nos diz pouco sobre as condições históricas que levaram Bogdánov a dedicar a essa teoria espaço central em seu sistema de pensamento. Neste capítulo procuraremos traçar a partir da apresentação do debate agrário entre os socialistas russos alguns fundamentos que permitam contextualizar a crítica de Bogdánov ao espaço alienado e como sua negação enquanto espaço utópico - desalienado - é apresentada em "Estrela Vermelha".

\subsection{O fim da servidão e a desestruturação da obshchina}

A partir da Reforma Alexandrina de 1861, o império russo passou por grandes transformações que alteraram significativamente todas as esferas da vida cotidiana, política, intelectual e econômica da sociedade russa. Dentre os diversos grupos sociais que compunham essa sociedade, nenhum foi tão afetado quanto o mujique, o camponês russo e sua organização comunal ancestral: a Mir. A libertação do servo de suas obrigações feudais possibilitou imediatamente a mercantilização da terra através da posse compulsória por parte do mujique. No entanto, o mesmo processo não se deu de forma instantânea em relação à força de trabalho. Por um período de adaptação, o camponês ainda se via submetido à corveia, uma vez que os lotes individuais eram desmembrados da propriedade boiarda, isto é, dos membros da nobreza russa que exerciam até então o poder de suserania sobre o campesinato. Para além do pagamento em força de trabalho, adicionou-se ao fardo dos 
trabalhadores uma taxa compensatória, a ser paga em 49 anos, com juros de $6 \%$ sobre o valor venal das terras que lhes foram destinadas. A essa condição somou-se o fato de que tal liberdade era apenas formal, uma vez que os lotes não eram distribuídos individualmente, mas ficavam sob responsabilidade da obshchina, o núcleo comunal camponês. Cabia à obshchina distribuir os lotes, arrecadar coletivamente os impostos e mesmo exilar membros dissidentes. $\mathrm{O}$ camponês acabou por substituir o domínio do amo pelo domínio da comuna (Wood, $1987: 25$ ).

De forma a operacionalizar a atuação da obshchina como órgão estatal, foram criados a partir da reforma administrativa de 1864 os Zemstva. Esses eram órgãos do poder estatal de caráter local ou distrital, cuja função abarcava uma ampla gama de atividades: contratação de especialistas (agrônomos, médicos, professores etc.); a aplicação de um novo sistema judiciário semelhante às reformas jurídicas alemãs de 1868, que garantiam o estabelecimento de um júri e a separação dos poderes no interior do Zemstvo; e a administração executiva a partir de um conselho composto por grandes proprietários agrários e membros eleitos entre os pequenos proprietários, o clero, a burguesia citadina, as classes urbanas subalternas e o campesinato, cujos representantes eram eleitos pelos Volosti (Wood, 1987:45). Se, por um lado a efetividade dos Zemstva foi em grande parte restringida pela natureza autocrática do estado russo, preso entre uma reforma modernizante e a manutenção de instituições arcaicas, por outro lado sua implementação teve papel fundamental na aproximação entre a Intelligentsia e o narod. É a partir desse contato entre a Intelligentsia, composta majoritariamente por substratos pequeno-burgueses que formavam o corpo técnico dos Zemstva, e a vida do mujique que se constituirá o narodnitchestvo, isto é, o conjunto de atividades teóricas e práticas da Intelligentsia militante dos anos 1860 e 1870 que buscava responder e defender os interesses do narod russo e a construção do socialismo a partir da obshchina (Laue, 1954:14).

A despeito dos objetivos da reforma, a produção agrícola russa por hectare permaneceu estagnada nas décadas seguintes à Reforma de 1861. Zaitsev \& Pares (1931:552) apontam que o loteamento das terras comunais na prática reduziu a área semeável disponível ao mujique, ao mesmo tempo 
em que o prendeu por meio da obshchina a esse mesmo lote, reduzindo suas possibilidades de expandir a produção. O aumento dos tributos, a falta de investimentos, o baixo nível técnico da produção, a restrição à mobilidade e a redistribuição periódica das terras impediam que a terra, já mercantilizada, fosse capitalizada pelos camponeses como bem de capital, produtor de mercadorias. A inserção da produção russa no mercado mundial de grãos acabou por precificar essa mesma produção, aumentando os custos e reduzindo o poder de compra dos produtores, que já não mais decidiam organicamente o preço dos frutos de seu trabalho. Ainda que essa inserção tenha aumentado o volume total da produção de grãos russa (um aumento de 160\% entre os anos de 1861 a 1892, de acordo com Hobsbawm 1988:405), isso ocorreu por meio da expansão das áreas agricultáveis, o que levou à redução da área de produção de subsistência dos camponeses, ao mesmo tempo em que estimulou o arrendamento das terras e a venda da força de trabalho mujique. As relações de produção capitalistas e a inserção da produção agrícola na lógica mercantil conviviam com formas de trabalho e estruturas administrativas feudais, exacerbando contradições que acabaram por desestruturar a obshchina. Foi também a partir dos anos de 1860 que o regime autocrático czarista, frente às derrotas na Crimeia e ao crescente abismo que o separava cada vez mais das economias ocidentais, tomou como necessário e inevitável tocar um amplo processo de modernização do Estado e, por definição autocrática, da sociedade russa. Além da reforma judiciária já mencionada, a autocracia abrandou a censura, estimulou o crescimento do sistema financeiro, reestruturou a hierarquia de oficiais do exército e reformou o sistema educacional, abrindo o ensino superior às classes subalternas. Tais medidas eram vistas como pré-requisitos para a formação de quadros técnicos, indispensáveis no processo de industrialização projetado para um futuro então próximo (Wood, $1987: 25)$.

Trotski (1908) estabeleceu 1861 como marco inicial de um novo período de desenvolvimento econômico russo, caracterizado pela expansão da rede ferroviária, construção de portos, do fluxo incessante de capitais estrangeiros, aumento das companhias de sociedade anônimas, introdução do padrãoouro e o aumento exponencial do débito nacional. Esse intenso processo 
de modernização transformou radicalmente as relações de produção e só foi possível com a expropriação do mujique, tornado exército de reserva à disposição das nascentes grandes indústrias russas. Na vanguarda desse processo encontrava-se a expansão da malha ferroviária, que atingiu mais de 30.000 quilômetros de extensão no final do século XIX. O controle estatal das ferrovias, aliado ao desenvolvimento do sistema de crédito, era visto como a mola-mestra do desenvolvimento econômico da Rússia. Além disso, o processo de industrialização, acelerado nos anos 1890 a partir das reformas de Serguei Witte, acabou por centralizar o desenvolvimento de fábricas de grande porte, sobretudo siderúrgicas, sob o comando das armas russas. Essas fábricas concentraram-se principalmente nas capitais de províncias e nos centros urbanos tradicionais. Coggiola (2017:SN) nos mostra que, no começo do século XX, mais da metade da força de trabalho fabril estava empregada em fábricas com mais de 500 funcionários, enquanto na Bélgica esse percentual atingia apenas $28 \%$. Em fábricas que empregavam mais de mil operários, esse percentual de empregabilidade era ainda maior: enquanto $38,5 \%$ da força de trabalho russa estava alocada nessas unidades produtivas, na Alemanha esse percentual era de $10 \%$.

Esse foi também o momento de radicalização política da Intelligentsia, um movimento que acompanha não apenas a desestruturação da comuna russa, como assiste ao processo invasivo das relações de produção capitalistas entre os grupos sociais russos. A leitura crítica e contemplativa hegeliana produzida pela nobreza radical dos anos 1840, representada por Herzen, Turguêniev e Dobrolyubov, dá lugar à radicalidade realista de Pisariev e Tchernitchevski, ao blanquismo de Lavrov e às primeiras leituras marxistas da realidade social russa a partir de Danielson e Mikhailovski. A questão agrária na Rússia extrapolava a defesa do narodnitchestvo ao apresentar um duplo sentido, um movimento que Lenin provou posteriormente ser falsamente dialético: a rejeição às formas de exploração capitalistas e, especificamente, à proletarização e industrialização da Rússia. Este foi um dos debates centrais sobre o qual se constituiu epistemologicamente o marxismo russo e a social-democracia. 


\subsection{A crítica narodnik: a questão do mercado interno}

Laue (1954:18) atenta para a indistinção entre capitalismo e indústria existente nas análises narodniks. Intelectuais como Nikolai Mikhailovski, Nikolai Danielson e Vasili Vorontsov acreditavam impossível a coexistência entre a crescente industrialização capitaneada pela autocracia e a sobrevivência da Mir. Nessa afirmação encontra-se o centro do credo narodnik: o capitalismo é uma força alienígena e invasiva, cujo resultado seria a capitalização das terras e a desintegração da vida comunal. Todos eles apontavam para a grande fome de 1891 como efeito direto do empobrecimento do campesinato a partir das terríveis taxações impostas pela Reforma de 1861 que acabou com a servidão ao mesmo tempo em que capitalizou as terras comunais, consequência do avanço do capitalismo sobre o campo.

Nikolai Mikhailovski, importante teórico da ala moderada do "Zemlya $i$ Volya" (Terra e Liberdade) - principal organização nadodnik dos anos 1870 e 1880 -, questionou o processo de acumulação primitiva proposto por Marx ao recusar aquilo que entendia ser uma "teoria histórico-filosófica do progresso mundial" (Mikhailovski, 1983[1876] :33). Ele se levantou contra a afirmação feita por Marx em réplica a artigo de sua autoria e publicado no periódico "Notas Domésticas", em que este havia defendido que dois pontos eram fundamentais para que a Rússia seguisse seu esboço de desenvolvimento histórico:

"(1) Se a Rússia tentar se tornar uma nação capitalista como as nações da Europa Ocidental[...] não será bem sucedida sem ter antes transformado uma boa parte de seus camponeses em proletários[...] (2) e, ao cruzar essa fronteira do sistema capitalista, deverá se submeter às leis inexoráveis de tal sistema, como todas as outras nações ocidentais." (Marx, 1983: 33)

Mikhailovski argumentou que esse ponto de não-retorno não era uma realidade inexorável e que a Rússia era capaz de produzir a partir de suas peculiaridades históricas novos rumos e formas de desenvolvimento. Para Mikhailovski, o desenvolvimento histórico dos países europeus não deveria 
servir de fundamento para pensar o desenvolvimento da própria Rússia. Esse acreditava ser possível reestruturar as arteli ${ }^{2}$ para darem conta da produção fabril leve, buscando por meio do desenvolvimento científico reduzir o impacto da industrialização sobre o campesinato. Nesse esquema caberia ao Estado operar a indústria pesada por meio de sistemas rotativos de trabalho que respeitassem o ritmo sazonal do trabalho campesino.

Nikolai Danielson, o principal correspondente russo de Marx, buscou explicar a partir da análise histórico-materialista esse processo de desagregação. Para Danielson, dois sistemas econômicos competiam em solo russo desde o fim da servidão de 1861, um confronto assimétrico cujos efeitos sobre a sociedade russa se aceleraram a partir dos anos 1880: de um lado a produção de subsistência campesina, assentada nas tradições comunais do mujique russo; do outro lado o enxerto artificial da capitalismo ocidental, capitaneado por um governo despótico e corrupto. A expansão da rede ferroviária fora financiada a partir dos pesados impostos que incidiram sobre o campesinato e acabou por capitalizar a produção agrícola, vinculando-a aos mercados estrangeiros a partir do comércio internacional de grãos. Esse processo não apenas passou a ser determinante para a flutuação de preços do grão, penalizando os produtores em favor de atravessadores e atacadistas, como também inseriu abruptamente a Mir na economia de mercado, tornando o mujique dependente de novas necessidades, inatingíveis devido ao elevado grau de empobrecimento do campesinato. Essa situação acabou sendo agravada pela progressiva desintegração das arteli. Incapazes de competir com a grande indústria, as arteli passaram a absorver cada vez menos mão-de-obra, diminuindo assim as possibilidades de ganho do mujique, restrito à agricultura como única atividade econômica (Naarden, $1992: 64$ ).

Sujeitos às determinações do mercado internacional de grãos e às taxas abusivas impostas pela privatização do solo levada à cabo pela Reforma de 1861, o campesinato russo acabara impossibilitado de adotar técnicas intensivas de produção. Limitados a formas de cultivo primitivas, acabaram

2 Arteli eram associações cooperativas de organização comunal, voltadas para a produção industrial leve, tanto de bens de consumo quanto de equipamentos agrícolas. Assim como a Mir, os membros das arteli eram camponeses que se dedicavam à manufatura no intervalo entre o plantio e a colheita, produzindo sazonalmente. Para mais informações, ver Confino (2011). 
por exaurir o solo e, por meio da pobreza generalizada, por constituir o exército de reserva que comporia a nascente classe operária russa. Para Danielson, a única saída para a Rússia e o narod seria reverter o processo de industrialização a partir da planificação da economia assentada na tradicional comuna russa (Naarden, $1992: 66$ ).

Vasili Vorontsov rejeitava absolutamente o caráter etapista do marxismo ortodoxo, transmigrado para a Rússia a partir da social-democracia alemã. Para ele, não apenas o processo de industrialização era indesejado, como impossível. Contra esse processo, atuavam os altíssimos custos de sua implementação. A partir de dados existentes, Vorontsov mostrou que as grandes distâncias existentes entre as zonas produtoras e os espaços de consumo e exportação, somadas às rigorosas condições climáticas da Rússia, tornariam as taxas de transporte proibitivas. Somando-se a esse cenário Vorontsov apontou para o obstáculo que a força de trabalho russa apresentava para o progresso industrial e urbano. Abundante e extremamente barata, tal força de trabalho desestimulava a introdução de maquinários e impedia o desenvolvimento de mão de obra qualificada. Nessas condições não apenas era impossível o desenvolvimento da uma classe operária, como também de sua contraparte: uma burguesia industrial. A partir dessas conclusões - que não devem nada ao marxismo mais vulgarmente determinista -, Vorontsov defendeu rejeição total ao credo etapista em prol da proteção intransigente da Mir. A construção do socialismo deveria ter como premissa a aproximação entre a Intelligentsia e o narod. Somente esse último poderia fornecer ao intelectuais as condições necessárias para a constituição de uma visão de mundo tanto socialista quanto russa. Caberia ao mujique ensinar o socialismo ao intelectual (Laue, 1954 : 18).

Essa rejeição obstinada à industrialização e à capitalização do campo não era um posicionamento restrito aos narodniks. A preservação do narodnitchestvo - a crença na particularidade do modo de vida mujique - era uma preocupação premente de diferentes setores da intelectualidade russa. Ao contemplar a formação de grandes centros industriais financiados pelo Estado czarista, Liev Tolstói, expoente do anarquismo russo, em 1901 escreveu:

"Olhe para as horrendas chaminés das grandes fábricas que estão agora 
espalhadas pela Rússia. Elas desfiguram a paisagem de Deus... tudo isto é um erro. Não temos mais do que cem milhões de habitantes. Pouco mais de um milhão desses encontram-se engajados na manufatura. Quão injusto que os restantes carreguem o fardo desses poucos! Nosso país é naturalmente agrícola. Nós somos um povo agrícola. Nenhum bem pode advir do abandono da tendência natural de nossas habilidades e condições físicas." (Tolstói, 1901, apud Beveridge 2007:430)

É importante salientar que essa apresentação das posições narodniks em relação à entrada do capitalismo na Rússia por meio da industrialização não obedece a uma ordem cronológica, mas antes tenta demonstrar a transformação dessas posições contextualizadas não apenas a partir do desenvolvimento histórico da Rússia, como também a partir de transformações significativas que ocorriam no próprio interior da Intelligentsia. Ainda que sejam contemporâneos, Danielson e Mikhailovski produziram a maior parte de suas críticas entre os anos 1870 e 1880, enquanto Vorontsov publicou principalmente no decênio posterior. Diferentemente de Danielson e Vorontsov, Mikhailovski entendia ser inevitável o processo de industrialização da economia russa. Frente à inexorabilidade desse processo, defendia sua orientação a partir da obshchina e de suas instituições de caráter comunal. É possível notar que a posição expressa por Mikhailovski já no final dos anos 1870 exibia pontos de contato com as posições da geração marxista dos anos 1890. Mikhailovski acreditava ser possível extrair da transformação empreendida pela industrialização sobre a sociedade russa elementos progressistas que contribuíssem para o aumento da produtividade. No entanto, tal processo deveria ser precedido pela constituição de um Estado socialista, a quem caberia o papel de implementar a indústria pesada sem colocar em risco o modo de vida do narod, ente cultural e social no qual se assentaria o novo Estado russo.

Em comum, todos eles foram profundamente influenciados pelo materialismo histórico e dialético de Marx, mas reagiram a esse de maneiras diferentes, influenciando com isso a própria recepção do marxismo entre a Intelligentsia narodnik. Danielson, primeiro tradutor dos três volumes d' "O Capital" para a língua russa, buscou adequar o método de análise marxista às lutas históricas da Intelligentsia, identificando no mujique o sujeito histórico revolucionário, concluindo não ser necessária qualquer transformação econô- 
mica e social de caráter capitalista (Shanin, 1983:133); Mikhailovski, por sua vez, se utilizou do mesmo método científico para explicar o desenvolvimento econômico da Rússia, admitindo no entanto a inevitabilidade da industrialização, fato que o levou a defender que os elementos mais progressistas desse processo fossem adaptados à realidade russa (Laue, 1954:17); Vorontsov destoa desse movimento de abertura - senão de aceitação - em relação à industrialização demonstrado por Mikhailovski.

Já no recesso do movimento narodnik, entre os anos 1880 e 1890, e na emergência do marxismo como principal orientação filosófico-política da Intelligentsia, Vorontsov, imerso no debate com os marxistas, mostrava uma mentalidade de "cerco", recusando quaisquer categorias de desenvolvimento econômico que possam aventar a possibilidade de coexistência entre o mundo industrial identificado ao avanço do capitalismo e a obshchina. Como vimos, Vorontsov não apenas rejeitou a formação de um proletariado como disse ser impossível que isso ocorresse, dadas as características geográficas, demográficas e históricas da Rússia. Tais fatores impediriam a criação de um mercado interno de consumo, condenando qualquer tentativa de industrialização ao espaço restrito da atuação estatal, impedindo assim o desenvolvimento de uma burguesia sólida e politicamente empoderada (Eaton, 1980:110).

Novamente reforçamos que esse fechamento de posição quanto aos benefícios e riscos da industrialização por parte da Intelligentsia narodnik se deu em meio às críticas da intelectualidade radical marxista. Mas da mesma forma que tais críticas produziram essa mudança de rumos nas teorias narodistas, também a recepção das teorias marxistas acabaram por se adaptar às pautas colocadas pelos narodniks. A concepção etapista de desenvolvimento econômico defendida pelas organizações social-democratas dos países ocidentais encontrava nas particularidades do sistema econômico-social russo um obstáculo intransponível quando o objetivo era simplesmente transplantar as experiências de classe do mundo europeu, baseadas em uma classe burguesa politicamente hegemônica e em um proletariado numeroso e bastante organizado, para uma sociedade autocrática, tecnologicamente atrasada e quase que totalmente desprovida das classes sociais constituintes do mundo burguês. 


\subsection{Plekhánov e a crítica marxista ao narodnitchestvo}

A ascensão do marxismo como fundamento teórico da Intelligentsia radical acompanha sincronicamente tanto a fração do principal partido narodnik Terra e Liberdade ("Zemlya $i$ Volya") - quanto a intensificação do processo de industrialização da economia russa a partir do final do anos 1880, capitaneado pelo Estado cszarista a partir da figura de Serguei Witte (1849-1915) (Fritzpatrick, 1994 : 25). Esses dois fatores atuam dialeticamente na formação do marxismo russo e não podem ser pensados de forma apartada. Com isso em mente, buscaremos apresentar a tensão desses dois elementos e de que forma essa tensão atuou na formulação particular da crítica marxista russa. Uma vez não ser esse o objeto central dessa análise, passaremos rapidamente pelas posições críticas da Intelligentsia marxista em relação às posições narodniks e ao processo de industrialização da Rússia a partir das contribuições de Plekhánov e Lenin, de forma a compreender como essas posições circundam a questão agrária e contextualizar a própria posição de Bogdánov expressa em "Estrela Vermelha".

Henry Eaton identifica a presença da obra de Marx entre os intelectuais russos já no final dos anos 1860 a partir de artigos e resenhas sobre sua obra publicados em periódicos como "Palavra Russa" e "Notas Domésticas". Importantes nomes do populismo russo como Piotr Lavrov, Ivan Fesenko, Nikolai Mikhailovski e Nikolai Danielson - já citados anteriormente - estabeleceram duradoura correspondência com o filósofo alemão e mesmo laços de afeto com sua família e colaboraram ativamente tanto em suas reflexões sobre a sociedade russa quanto na divulgação de sua obra entre a Intelligentsia. Não obstante o comprometimento desses nomes com a recepção das ideias de Marx e o interesse desse na atuação revolucionária dos radicais russos, pouco se sabia dentro da Rússia sobre seu trabalho e obra. Não é possível, de acordo com Eaton, falar até o começo dos anos 1870 de um movimento verdadeiramente marxista, ainda que encontremos em figuras como Mikhailovski e Danielson tentativas em interpretar o desenvolvimento econômico da Rússia a partir da perspectiva científica do Materialismo Histórico (Eaton, 1980 : 117). 
O empobrecimento do campesinato aliado ao avanço da industrialização e ao fracasso do movimento "em direção ao povo" (khozhdenie v narod) evidenciou para os intelectuais narodistas o enorme hiato que existia entre suas concepções idealistas acerca do narod e o universo conservador do mujique, acabando por catalizar uma série de transformações dentro da organização política do narodnichestvo. Em 1876, o movimento narodista "Zemlya $i$ Volya" foi "refundado", abarcando uma ampla gama de posições históricas, notadamente as posições de Lavrov, Bakunin e Tkatchov (Belfer, 1978:309). A questão que se colocava aos narodniks era de natureza essencialmente tática: o que fazer diante do fracasso da marcha em direção ao povo? As respostas envolviam definir as opções que cabia à Intelligentsia nesse contexto e não eram poucas. Para a maioria de seus membros, assim como era para Piotr Tkatchev (1844-1886), caberia à Intelligentsia sufocar o aparelho autocrático pelo terror e conspiração, reduzindo sua capacidade de oprimir o narod; outros, a partir da tática proposta por Mikhail Bakunin (1824-1876), defendiam a espontaneidade do narod, cabendo aos intelectuais a coordenação de revoltas camponesas locais, objetivando uma revolução nacional; a partir do programa de Piotr Lavrov, uma minoria, por fim, se posicionava a favor da elaboração de um programa voltado à propaganda e educação dos mujiques ao ponto de fomentar, a partir daí, um amplo sentimento de insurreição (Belfer, 1978:311).

Belfer (1978:311) aponta para a impossibilidade do coexistência entre posições táticas tão díspares dentro de um único partido. Os populistas acabaram clivados pela contradição essencial com a qual denominaram sua organização: de um lado, "Zemlya" (terra), uma confiança espontaneísta no potencial subversivo do narod, adormecido por séculos de tradição autocrática, cujo despertar caberia aos esforços propagandísticos e de agitação da Intelligentsia; do outro "Volya" (vontade), prenunciava a formação de uma vanguarda profissional, inteiramente dedicada à condução do processo revolucionário e à desestabilização do regime autocrático por meio de atentados e assassinatos. Colocadas na mesa do debate narodista estavam duas questões centrais: o sujeito revolucionário do socialismo russo e o papel dos intelectuais nesse processo. Essas não eram questões que atormentaram tão somente os 
narodniks, mas que foram herdadas nos anos 1890 pelos social-democratas do POSDR - centrais para o cisma de 1903 - e na primeira década do século XX pelos bolcheviques, resultando no cisma do centro bolchevique em 1909. É possível afirmar com alguma certeza que a história do movimento socialista russo é, em grande medida, a história do desenvolvimento dialético dessa problemática.

Esse impasse, somado à intensa repressão do Estado czarista em resposta à tentativa de assassinato empreendida por Vera Zasulitch contra o General Trepov em janeiro de 1878 e que levou à prisão e exílio de diversas células revolucionárias populistas, foram determinantes para a brevidade do "Zemlya i Volya" enquanto unidade política (Venturi, 1960 :598-599). Já em 26 de agosto de 1879, três anos após sua refundação, o partido acabou por se dividir em duas frações. De um lado estava a fração composta pela maioria dos populistas, o "Sotsialno-Revolyutsionaya Partiya Narodnoi Voli" (Partido Social Revolucionário da Vontade do Povo), ou simplesmente "Narodnaya Volya" (Vontade do Povo), organizado a partir da decisão do Comitê Central do partido em se opor ao Estado czarista a partir do enfrentamento armado. Sua ampla capilaridade de atuação, seja por meio de células e círculos de estudo em cidades como Moscou, São Petersburgo, Ekaterinburgo, Baku e Karkhov, bem como um amplo trabalho de recrutamento entre o nascente proletariado russo, possibilitou um reavivamento dos ideais populistas entre a intelectualidade russa, não obstante o fracasso da tática de ação direta implementada pela organização como forma de desestabilizar o regime. Massacrado pelas forças policiais em 1887 após dezenas de tentativas de assassinatos, a principal herança do Narodnaya Volya será a fundação teórica e de quadros para o futuro Partido Socialista Revolucionário, importante agente radical na primeira década do século XX e descendente direto dos narodniks do século XIX. Em oposição ao uso exclusivo da ação direta preconizado pelo Narodnaya Volya, uma minoria formou-se em torno de uma nova publicação, Tchiorny Peredel ("Partição Negra"), cuja denominação acabou por denominar posteriormente essa facção. Entre seus líderes encontrava-se, na linha de frente dos debates táticos entre as duas frações, Georgi Plekhánov, que depois seria considerado pai do marxismo russo e um dos principais oponentes 
teóricos do bolchevismo.

De acordo com Shanin (1983 : 204) e Venturi (1960:600), a Partição Negra nunca conseguiu se consolidar enquanto grupo revolucionário relevante. Seu apelo para que os intelectuais retornassem às aldeias de forma a educar o narod encontrou não apenas resistência entre diversas células narodistas, como também forte repressão por parte da polícia, alertada antecipadamente das atividades do grupo tanto por funcionários dos Zemstva, como pelos próprios camponeses, receosos da repressão czarista. Em janeiro de 1880, após a atuação de um agente infiltrado na gráfica de impressão do periódico, diversos membros do Comitê Central da Partição Negra acabaram detidos por agentes da repressão czarista, obrigando seus líderes - entre eles Plekhánov e Vera Zasulitch - a partir para o exílio. Esse foi o fim da Partição Negra enquanto facção, ainda que o periódico tenha sido publicado em Genebra de forma mais ou menos regular, até 1881, servindo como primeira plataforma de agregação dos marxistas russos, tais como Plekhánov e, posteriormente, Pavel Akselrod.

No exílio Plekhánov aderiu rápida e irreversivelmente ao materialismo histórico como ferramenta de análise da sociedade russa, ainda que tal processo não tenha sido inesperado. Já em 1879, Plekhánov defendia que o marxismo: “...não era apenas relevante para [compreender] as sociedades capitalistas, mas para [compreender] todas as sociedades"(Baron, 1954:41). Naquele momento Plekhánov ainda se alinhava ao narodismo pois, a despeito de suas leituras iniciais da obra de Marx, acreditava que a obshchina ainda era um elemento estável na organização econômica russa, diferentemente do que ocorreu com a propriedade comunal na Europa Ocidental, enfraquecida pelo processo de acumulação primitiva. Foi durante o exílio, a partir de 1880, que sua confiança no narodnitchestvo foi rapidamente corroída, acabando substituída pelo marxismo. O contato com socialistas franceses como Jules Guesde e intensos estudos sobre Socialismo, História, Economia Política e a obra de Marx e Engels o afastaram ainda mais do narodnitchestvo, possibilitando em um curto espaço de tempo uma perspectiva crítica do narodismo russo. Já em setembro do mesmo ano, em artigo publicado no periódico Tchiorny Peredel, Plekhánov defendeu que "o próximo estágio da 
Rússia seria provavelmente um regime burguês-liberal". No mesmo artigo, Plekhánov afirmou que "enquanto a questão agrária ainda é a principal preocupação dos socialistas, a indústria russa avança e, com ela, o centro de gravidade das questôes econômicas é transferido para os centros industriais" (Baron, 1954: 45).

Em 1882, ao escrever o prefácio da $2^{\text {a }}$ edição russa do "Manifesto Comunista", Plekhánov rompe abertamente com o narodnitchestvo ao argumentar que a "única rota de desenvolvimento possivel para a Rússia é a rota do capitalismo" (Baron, 1954:47). Essa conclusão, construída a partir da revisão de suas posições à luz do marxismo, acaba por tornar irrelevantes as divisões táticas entre Narodnaya Volya e Tchiorny Peredel. Plekhánov passa a defender que a luta política (enquanto luta por direitos políticos) e atividade socialista (trabalho de agitação e propaganda entre as massas) não só não são excludentes como são fundamentalmente complementares, e apenas através da criação de um partido de massas e da luta política pela melhoria objetiva das condições de existência da classe trabalhadora seria possível atingir o socialismo. O capitalismo e a industrialização não eram apenas inevitáveis mas bem-vindos pois dinamizariam a vida econômica e política da Rússia e possibilitariam tanto o surgimento de uma classe burguesa industrial, quanto a formação de uma classe proletária, cujo papel futuro seria fornecer o alicerce para a futura revolução socialista, a qual deveria ser antes precedida por uma revolução burguesa. Estavam lançadas as bases do programa social-democrata (Baron, 1954: 49).

Em 1883, Plekhánov, ao lado de Pavel Akselrod, Vera Zasulitch, Vasili Ignatov e Leo Deutsch, acabou por fundar uma nova organização: "Osvobozhdenie Truda" (Emancipação do Trabalho), com o intuito de preparar uma "biblioteca do socialismo moderno", cujo objetivo seria traduzir as obras de socialistas contemporâneos que estivessem ainda indisponíveis para os falantes da língua russa, bem como publicar suas próprias obras. Para além dessa intenção inicial, a biblioteca também serviu como quartel de onde Plekhánov dirigiu uma série de ataques às posições centrais do narodismo (Derek, $1986: 128$ ).

A partir da biblioteca, Plekhánov publicaria seus dois mais importantes 
trabalhos daquele período: "Socialismo e Luta Política" (1883) e "Nossas diferenças" (1885). Nesses textos, Plekhánov buscou colocar por terra os principais pilares do narodnitchestvo ao demonstrar que as particularidades russas não eram uma demonstração de sua unicidade mas, ao contrário, de seu atraso. A partir da leitura do Capítulo 24 d' "O Capital" que trata da acumulação primitiva, Plekhánov salientou que o processo de desintegração da obshchina não decorria da introdução de um elemento alheio às tradições russas, mas antes era justamente o processo histórico que precedia a revolução produtiva capitalista, ao separar do camponês os meios de produção que possibilitam sua autonomia produtiva, da mesma forma que ocorreu na Inglaterra entre os séculos XV e XVIII, conforme descreveu Marx. A partir desse postulado, Plekhánov defende que será necessária a consolidação de uma fase capitalista para a constituição das classes políticas burguesa e operária, pré-requisitos para a futura revolução socialista (Plekhanov, 1883).

Ao buscar no socialismo científico e em dados econômico-sociais mensuráveis as ferramentas necessárias para compreender o processo de fragmentação da obshchina, Plekhánov abriu um novo capítulo no centenário debate que dividia a intelectualidade russa entre eslavófilos e ocidentalistas, alinhando-se a esses últimos. Tal debate foi travado com Tikhomirov - membro original do Comitê Central do Narodnaya Volya - cujos argumentos se fiavam nas críticas de Vorontsov ao ocidentalismo presente nas análises marxistas. Plekhánov mostrou por meio de fortes evidências que não apenas o desenvolvimento do capitalismo russo era similar ao mesmos processos históricos ocorridos entre os países europeus, como qualquer estratégia que não tome o proletariado como sujeito revolucionário de um processo posterior à industrialização capitalista estaria fadado ao fracasso. A partir de suas críticas, Plekhánov logrou abalar dois pilares fundamentais do narodnitchestvo: a crença no caráter único do devir histórico da Rússia; e a fé no campesinato enquanto sujeito revolucionário (Baron, 1954:51).

Derek Offord observa que, não obstante a solidez dos argumentos de Plekhánov, o grupo "Osvobozhdenie Truda" logrou pouco êxito em difundir o marxismo entre a Intelligentsia russa em seus anos iniciais, em parte pela ausência de um agente organizador, uma vez que seu principal propagandista, 
Vasili Deych, acabou preso em 1884, rompendo com isso a conexão entre os "trudistas" e as principais células revolucionárias russas, em parte pelo marxismo intensamente determinista de Plekhánov, formado a partir de seu debate com os narodistas. Ao mesmo tempo em que condenava o "jacobinismo" narodista - atacando assim a principal tática de ação da radicalidade russa - Plekhánov postergava a promessa de socialismo para um futuro incerto, insistindo no papel maximalista dos intelectuais, cabendo a eles tanto o cultivo da consciência da classe trabalhadora quanto a luta econômica pela melhoria das condições objetivas de sua existência. Esse isolamento começou a ruir nos anos finais da década de 1880 a partir do momento em que o fracasso da tática de ação direta do Narodnaya Volya tornou-se inegável. Em janeiro de 1887, centenas de células narodistas foram desmanteladas pela polícia czarista levando ao esfacelamento do movimento. Esse evento permitiu uma reavaliação das críticas de Plekhánov e dos trudistas e acabou indiretamente por fomentar a difusão de obras do socialismo científico por diversos círculos operários e estudantis (Derek, 1986 : 131).

O vácuo deixado pelo fracasso das táticas narodistas, somado à intensificação das reformas do Ministro Witte, responsáveis pela expansão acelerada do parque industrial russo, estimularam um ambiente político e intelectual fértil para o florescer de uma nova geração de intelectuais radicais, proveniente das universidades e clubes operários, cujos espaços de atuação eram essencialmente urbanos e fabris. Tais círculos de estudo, agitação e propaganda se espalharam rapidamente por todas as grandes cidades russas, como Moscou, São Petersburgo, Kazan e Karkhov, e formaram alguns dos principais exponentes do marxismo russo e da futura facção bolchevique, como Vladimir Lenin e Aleksandr Bogdánov.

Se parece consenso na literatura que o impacto inicial dos trudistas foi limitado, restrito aos emigrées russos que viviam na Europa Ocidental, também parece ser consenso que foi a partir das críticas de Plekhánov que se constituiu o alicerce intelectual que sustentou o desenvolvimento da socialdemocracia russa. Seu trabalho, ainda que criticado por seus contemporâneos como determinista e antidialético, acabou por servir como ponta de lança para o desenvolvimento e posterior hegemonia da epistemologia marxista 
como principal orientação filosófica para as gerações radicais posteriores.

\subsection{Lenin e os narodniks: O debate acerca da industrialização nos anos 1890}

A partir dos anos 1890, o debate entre narodniks e marxistas ganhou novos contornos. A intensificação do processo de industrialização, somado à difusão de círculos revolucionários entre estudantes e operários nos grandes centros urbanos levou ao crescimento da social-democracia russa enquanto proposta de organização tática e possibilitou a difusão do pensamento marxista entre uma nova geração de radicais. Tais círculos estreitaram as relações entre jovens estudantes e líderes proletários, possibilitando uma aproximação de ambas as partes. Diversos círculos operários contavam com a presença de membros da Intelligentsia em suas reuniões e esses, muitas vezes, ministravam aulas aos operários e usavam os espaços para propaganda revolucionária. É importante ressaltar a dificuldade que a literatura encontra em precisar o impacto das ideias marxistas nesses círculos durante a passagem entre as décadas de 1880 e 1890. A despeito da dissolução das células mais ativas do Narodnaya Volya pela polícia czarista, o narodismo ainda era o fundamento político precípuo da Intelligentsia e assim o foi nos anos seguintes, principalmente através do Partido Socialista Revolucionário, fundado em 1900. Além disso, o Estado policial czarista forçava tais círculos a serem secretivos e raramente era possível inferir de fora quem eram os seus participantes. Não obstante, tais círculos foram palcos de intensos debates entre narodistas e a nascente social-democracia e foi a partir do círculo de Fedosêiev, instalado na cidade de Kazan, que Vladimir Ilitch Ulianov acabou por assimilar o marxismo como princípio (Derek, 1986 : 149).

Expulso em 1887 da Universidade de Kazan e preso por conta de sua participação em atividades de protesto organizadas contra o "Ato das Universidades" - que restringiam o acesso de jovens das classes subalternas ao ensino superior -, Vladimir Ulianov (Lenin) acabou deportado para o município de Kokuskino, onde estudou intensamente a obra de importantes teóricos 
populistas como Vorontsov, Danielson e, em especial, Tchernichevski, cuja obra "O que fazer?" o impactou profundamente (Derek, $1986: 150$ ).

Para além dos textos clássicos do narodnitchestvo, Lenin também estudou obras da tradição marxiana e do socialismo europeu, como Lassalle, Kautski e Plekhánov. Também foi nesse período que Lenin, de acordo com sua companheira Nadezhda Krupskaya, leu o primeiro volume d' "O Capital", obra que, de acordo com sua irmã Anna, o fascinou e foi fundamental para sua conversão ao marxismo (Derek, 1986 : 152). Entre os anos de 1887 e 1889 Lenin frequentou um dos Círculos de Estudo de Fedosêiev localizado em Kazan ainda que, de acordo com Derek Offord, ambos nunca tenham se encontrado ${ }^{3}$. A partir de 1889, Lenin passou a viver em Samara, onde tornou-se colaborador de Sklyarenko, um dos principais organizadores de círculos revolucionários da região, e de Subanaiev, de quem aprendeu técnicas de organização e propaganda. Essa pequena descrição da trajetória inicial de Lenin nos permite vislumbrar uma formação teórica e prática devedora da longa tradição conspiratória narodista e que não se restringe a Marx ou Tchernichevski, mas que bebe também da tradição jacobinista de Lavrov, da ação-direta de orientação bakuninista, do socialismo francês e da social-democracia ocidental (Krausz, 2015 : 38). Em 1893, Lenin mudou-se para São Petersburgo, envolvendo-se ali com o círculo marxista do Instituto de Tecnologia ao lado de futuros líderes políticos e revolucionários da social-democracia russa como Leonid Krasin e Stepan Radtchenko (Derek, 1986 : 156).

Ainda naquele ano, Nikolai Mikhailovski e Sergei Yuzhakov, em uma série de artigos publicados na revista "Russkoe Bogatstvo" lançaram ataques tanto à teoria marxista quanto ao crescente movimento social-democrata russo. Antigo admirador da teoria marxista - como pudemos acompanhar anteriormente - Mikhailovski, frente ao crescimento da social-democracia, passou a lançar uma série de ataques tanto às posições táticas e programáticas dos social-democratas quanto à própria teoria marxista. Para ele a epistemologia marxista era essencialmente não-materialista e anti-científica. Não-materialista porque determinista, uma vez que o materialismo histórico

3 Em 1889, Lenin viajou para Samara e lá se encontrava no momento em que Fedosêiev e outros membros do círculo de Kazan acabavam presos pela polícia czarista (Derek, 1986:155) 
de Marx acabava por simplificar as inúmeras relações sociais como reflexos das relações de produção; anti-científica porque adequou suas hipóteses para comprovar um postulado desenvolvido a priori: a luta de classes como força motriz do processo histórico. Para além dessas críticas teóricas, Mikhailovski reafirmou a "rota russa" para o socialismo por meio das instituições pré-capitalistas russas manifestas na obshchina e na Mir. A produção em pequena escala, baseada no controle individual dos meios de produção era, para Mikhailovski, a chave para impedir o processo de especialização do trabalho e sua consequente socialização, cuja principal consequência seria o empobrecimento de vastos segmentos da população. A preservação da corveia era um exemplo daquilo que Mikhailovski entendia por formas de trabalho não-capitalistas e que deveriam ser preservadas contra o avanço da economia de mercado. Tratava-se portanto de "escolher" quais elementos da velhas ordens - capitalista e feudal - seriam benéficas para a constituição do socialismo. No centro da crítica, alinhada à preservação da "rota russa", encontrava-se uma condenação explícita à tática e teoria social-democratas, que buscavam em ideias "estrangeiras" prescrições alheias à realidade russa e que se encontravam em desacordo com a longa tradição radical da Intelligentsia russa (Shanin, 1983: 79).

Foi a partir de São Petersburgo que Lenin, já então um membro da social-democracia russa, deu combate às ideias de Mikhailovski e inaugurou destarte uma segunda frente no embate entre narodistas e social-democratas. Em abril de 1894 Lenin publicou seu famoso panfleto "O que são os "amigos do povo" e como eles combatem a social-democracia" (OQS) em que, de forma sistemática, atentou minar cada posicionamento e contradição demonstrados por Mikhailovski em seus artigos. Dividido em três partes devido às questões logísticas que dificultavam a publicação de materiais ligados à intelectualidade radical, OQS nos fornece já naquele momento embriões daquelas que se tornariam, de acordo com Tamás Krausz, características indeléveis do pensamento de Lenin: uma profunda capacidade crítica em operar dados empíricos e particularizados e adequá-los a uma teoria social ampla e geral sem perder de vista nesse processo as questões táticas impostas por necessidades objetivas e cotidianas (Krausz, 2015:81). 
Em OQS, Lenin concentrou suas críticas na desconstrução dos preceitos econômicos do narodnitchestvo, em especial na crença de reestruturação das forças produtivas russas em torno de unidades individuais e de caráter privado defendida por Mikhailovski, objetivo que se encontrava em risco devido ao avanço do capitalismo, uma força econômica estranha ao mundo social e econômico russo. Para Lenin, os narodniks insistem em um argumento metafísico: a ilusão de que é possível "escolher" elementos do sistema capitalista, i.e. conservar relações de produção feudais enquanto se rejeitam outros elementos. Em artigo de novembro de 1892, publicado no periódico narodista "Notas Domésticas", Mikhailovski defendeu a propriedade da terra pelo produtor direto como um ideal basilar do narodismo, enraizado na corveia medieval como relação de produção fundamental do mundo agrário russo: "As formas medievais de trabalho ainda existentes em nossa sociedade foram seriamente comprometidas, mas não vemos razão para colocar um fim nelas em favor de quaisquer doutrinas, liberal ou não-liberal" (Mikhailovski, 1892, apud Lenin 1893 : np). Ainda que não tenhamos acesso a esse documento enquanto fonte primária, nos restando confiar no relato de Lenin, é possível concluir a partir das exposições prévias que Mikhailovski entendia ser devido à intrusão das relações de produção capitalistas que tais formas medievais de organização do labor, cuja preservação denotava o caráter único da obshchina em contraste com o desmantelamento das propriedades comunais europeias, encontravam-se abaladas. De acordo com o intelectual narodista:

“...nossa tarefa não é recuar até nossas profundezas nacionais, a uma civilização que é positivamente original; mas tampouco é transplantar a civilização ocidental in toto, junto com todas as contradiçôes que a vêm rasgando; nós devemos pegar o que é bom de onde quer que venha; se isso é nosso ou estrangeiro não é uma questão de princípio, mas de conveniência prática." (Mikhailovski, 1892, apud Lenin 1893 :np)

Para Lenin essa abordagem "pinça um fenômeno isoladamente - a propriedade da terra em suas formas medievais - e acha que pode ser transplantado para todas as outras formas, assim como um tijolo pode ser transferido de um edifício para outro" (Lenin, 1893). Os narodistas acreditavam, de acordo com o jovem social-democrata, na permanência das antigas relações de produção, 
resistentes ao avanço do capitalismo. Tal constatação por sua vez sustentou a tese de Vorontsov entre os economistas populistas, i.e. a impossibilidade tanto da formação de um mercado interno quanto da realização da mais-valia, e portanto a inaplicabilidade do sistema capitalista em solo russo. Sua leitura aprofundada d' "O Capital", texto utilizado sobretudo por Mikhailovski e Vorontsov, acabou por destruir esses dois fundamentos da crítica narodista à industrialização.

Lenin parte da premissa de que a formação do mercado pressupõe a existência de uma economia mercantil, cujo desenvolvimento engendra transformações nas relações de produção, que por sua vez atuam como força motriz na transformação dessa economia mercantil em uma economia capitalista. Essa correlação se sustenta na lei de acumulação de Marx, que versa sobre o processo de metamorfose da reprodução simples do Valor - característica da produção natural - para a reprodução ampliada de Valor, processo fundante do sistema capitalista. Da economia natural, objetivada na produção familiar, artesanal e fundada na produção de valores de uso, as transformações produzidas pela inserção da categoria mercantil gestam a produção voltada para a criação de valores de troca, a redução do número de proprietários e a expansão das unidades produtivas. O Capital, enquanto Valor que se auto-valoriza, estimula a socialização do trabalho a partir da ampliação de setores produtivos cada vez mais interdependentes, voltados para a produção de mercadorias. Esse processo por sua vez se desenvolve concomitantemente à expropriação das classes produtoras das ferramentas necessárias para a reprodução social de sua existência. A socialização do trabalho ocorre assim tanto pela concentração de capitais nas mãos de um grupo cada vez mais restrito quanto por uma especialização social do trabalho cada vez mais abrangente. Enquanto a produção doméstica-natural caracteriza-se pela operação simultânea das diversas etapas necessárias para a produção de mercadorias por parte de produtores que atuam de forma independente uns dos outros, na produção capitalista:

\footnotetext{
"o número de ramos separados da produção aumenta (...) essa divisão e a concentração da produção enseja o surgimento de novos ramos: construção de máquinas, mineração e assim por diante. Em cada ramo,
} 
que se torna cada vez mais especializado, o número de capitalistas reduz sensivelmente." (Lenin, 1893)

A partir do pressuposto de que o processo de acumulação do Capital promove a divisão social do trabalho e é por essa impulsionado, Lenin passa a verificar se a socialização do trabalho e a expropriação dos produtores diretos está ocorrendo em solo russo. Essa abordagem foi fundamental para refutar os narodistas, que enxergavam no mujique uma classe social homogênea, na corveia sua relação produção central e na obshchina sua formação social original. Para tanto Lenin se utilizou de uma vasta quantidade de dados produzidos pelos Zemtsva e organizados por historiadores estatísticos como Nikolai Postnikov. A partir desses dados Lenin demonstra que o debate empreendido pelos narodistas - acerca da possibilidade de se evitar uma fase capitalista para construção do socialismo a partir da obshchina - era não somente infrutífero, como obsoleto. O capitalismo já era uma realidade e as relações de produção do campesinato russo foram irreversivelmente transformadas por ele. As reformas alexandrinas de 1861 deram fim ao regime de servidão, assim como também propiciaram uma ampla expropriação do campesinato. Lenin mostra que, já nos anos seguintes à reforma, parcelas expressivas do campesinato passam a produzir para o mercado e a vender a força de trabalho não mais em espécie ou por arrendamento (formas de exploração típicas da corveia), mas por salário. A constituição do proletariado rural se desenvolve contemporaneamente à concentração de terras nas mãos de uma pequena classe camponesa abastada e à introdução de novas técnicas de produção agrícolas e manufatureiras, cujo crescimento se acelera conforme se consolida no campo a economia de mercado (Lenin, 1893).

Lenin demonstra que a produção da economia natural sob a égide do mercado já não permitia que os camponeses pobres e médios reproduzissem a partir de suas propriedades sua própria força de trabalho. Entre os camponeses médios, 19\% de sua renda advinha da produção industrial, isto é, da venda de sua força de trabalho nos diversos ramos da indústria agrícola ou manufatureira. Entre os camponeses pobres esse percentual era ainda maior: $24 \%$ da renda desses camponeses advinha da venda da força de trabalho (Lenin, 1893). Ele enxergou nesses dados um processo de 
diferenciação social em percurso, em que os setores superiores do campesinato acabavam por se aburguesar ao mesmo tempo em que os setores inferiores se proletarizavam. A partir dessa diferenciação, Lenin demonstra que é justamente na heterogeneização do campesinato em novos extratos sociais proporcionada pela socialização do trabalho que se dá o desenvolvimento do mercado interno. O crescimento do trabalho assalariado demonstra a importância cada vez maior que o salário exerce para o sustento dos mujiques, importância inversamente proporcional à riqueza do subgrupo ao qual o camponês pertence. Em oposição à teoria de Vorontsov, Lenin demonstrou que a expropriação do campesinato não é fator impeditivo para o desenvolvimento do mercado interno. Ao contrário, é a ruína do campesinato e sua proletarização que criam o mercado interno ao modular as relações de produção sob a lógica da produção de mercadorias:

“...A Rússia rural constitui um sistema de pequenos mercados espalhados (ou pequenas ramificações de um mercado central) que regula a vida econômica e social de pequenos distritos separados. E, em cada um desses distritos, nós encontramos o fenômeno que é, em geral, particular à organização econômico-social cujo regulador é o mercado: encontramos a divisão de produtores patriarcais até então diretos em ricos e pobres; nós testemunhamos a ascensão do Capital, especialmente do capital mercantil." (Lenin, 1893)

Em "Reconstruindo Lenin", Krausz (2015 : 58) observa que a publicação de OQS, além do manuscrito "A propósito da questão dos mercados", publicado postumamente em 1937, serviram como os primeiros fundamentos a partir dos quais Lenin elaborou o eixo teórico-metodológico que orientou sua principal obra de economia política: "O desenvolvimento do capitalismo na Rússia", publicado em 1899. Nessa obra, Lenin opera a crítica à teoria econômica narodista costurada à análise qualitativa de uma vasta quantidade de dados para demonstrar não apenas a solidez de suas observações produzidas no debate com os narodistas do começo dos anos 1890, como também para compreender o processo de industrialização em larga escala pelo qual passavam as grandes cidades russas. Lenin demonstra a partir do desenvolvimento da economia mercantil simples em economia capitalista o amplo processo de diferenciação social que perpassa todas as camadas sociais 
russas, notadamente no campo. A divisão social do trabalho transformou o campo russo em uma indústria, isto é, em um ramo produtor de mercadorias (Lenin, 1982b: 14).

O fim da servidão e as pesadas taxas de indenização impostas sobre os camponeses levaram à desestruturação da Mir por meio do empobrecimento dos pequenos produtores, transformando dessa forma grandes contingentes de produtores em trabalhadores assalariados. Essa transformação não indica tão somente a passagem de uma economia natural para uma forma mercantil, mas aponta principalmente para a concentração dos meios de produção nas mãos de uma nascente burguesia e de sua conversão em capital passível de ser valorizado por meio do trabalho vivo de seus antigos proprietários, agora assalariados. De acordo com Lenin é justamente o duplo sentido da lei geral de acumulação ampliada, i.e. a expropriação dos meios de produção e sua conversão em bens de capital e formação da força de trabalho assalariada, que possibilita a reprodução das relações de produção capitalistas e o consequente desenvolvimento do mercado interno (Lenin, 1982b:18). Lenin também demonstrou, com base na análise marxiana de realização do Capital a partir dos setores de bens de consumo e de capital expressa no Livro II d' "O Capital" (Marx, 2010:693), não apenas a falibilidade da teoria narodista que apontara para a não-realização da mais-valia, como o processo de reprodução ampliada do capital russo encontrava-se em perfeita sintonia com as ponderações de Marx no que concerne à acumulação primitiva: a reaplicação dos meios de produção expropriados na forma de capital constante tende a superar o investimento em capital variável com vistas a garantir ganhos de produtividade ao mesmo tempo em que restringe cada vez mais o acesso do pequeno produtor às inovações tecnológicas. Dessa forma o mercado interno e a realização da mais-valia alavancam-se primariamente no setor produtor dos meios de produção. Não é o mercado interno que cria as condições de realização e de desenvolvimento das forças produtivas. Predeterminado economicamente, o mercado interno desenvolve-se com o desenvolvimento do capitalismo, cujo devir aprofunda a divisão social do trabalho e separa os produtores diretos das ferramentas necessárias para a reprodução social de suas existências: "O grau de desenvolvimento do 
mercado interno é o grau de desenvolvimento do capitalismo em um país" (Lenin, $1982 b: 33$ ).

A partir desses pressupostos, Lenin se utilizou de uma vasta quantidade de dados censitários dosZemstva da Nova Rússia para analisar minuciosamente o processo de diferenciação social e desenvolvimento do capitalismo em solo russo, produzindo outrossim não apenas aquilo que Petrag Vanicki considerou "a definitiva refutação das ilusões populistas de Vorontsov, Karishev e Danielson" (Lenin, 1982b:xx) mas, nas palavras de José Paulo Netto, um: "método que, face à irredutivel particularidade que constitui cada formação econômico-social, se recria no confronto com a empiria, cuja aparente opacidade é ultrapassada e dissolvida na captação de sua essência movente" (Lenin, $1982 b$ : xxi). No decorrer da obra não apenas Lenin comprova os erros teóricos dos economistas populistas como aprofunda suas análises por meio da crítica da crítica. As relações sociais que dominam o campo apresentam todas as contradições de uma economia mercantil (concorrência, monetização da terra, produção para o mercado, decomposição do campesinato em diversos estratos sociais, a constituição de um proletariado rural) e mostram que o campesinato russo e seu desenvolvimento encontravam-se sujeitos às leis de acumulação do Capital, colocando por terra a ilusão da particularidade do mujique, categoria eslavófila cara aos narodistas (Lenin, 1982b:113).

A desintegração do campesinato atua sincronicamente à concentração de capitais em sistemas industriais de produção cada vez maiores que, para garantir a reprodução ampliada, acabam por pressionar a demanda por bens de capital, desalojando a pequena produção manufatureira de natureza familiar em favor da produção industrial em larga escala, de propriedade kustar, cujo desenrolar acelera a proletarização e aprofunda a produção socializada capitalista. Lenin mostra assim que a descamponização e a ubiquidade das relações de produção mercantis afetam a produção agrícola comunal da Mir bem como leva à desintegração das arteli, promovendo assim o desenvolvimento da manufatura capitalista e da classe proprietária do kulak (Lenin, 1982b:302). Lenin também salienta que as reformas de Witte promoveram um amplo desenvolvimento do sistema fabril a partir do investimento de capital estrangeiro na indústria pesada. Esses investimentos 
capitaneados pelo Estado czarista alteraram radicalmente as relações de produção nas grandes zonas de industrialização fabril, como Moscou, São Petersburgo e Baku. O autor mostra, a título de exemplo, o crescimento das grandes indústrias fabris entre 1866 e 1895: enquanto fábricas de grande porte $^{4}$ totalizavam apenas 42 estabelecimentos em 1866 em um universo fabril de 644 unidades, no biênio de 1894/95 essas unidades já totalizavam 117 fábricas e já empregavam a maioria dos operários distribuídos entre os empreendimentos fabris (259.541), superando as fábricas pequenas (252.676) e de médio porte (143.453). Além disso, todas as unidades de produção em larga escala utilizavam-se de máquinas a vapor, o que demonstra a aceleração do processo de mecanização da produção (Lenin, 1982b:324). Nesse intervalo temporal, a população empregada na indústria fabril saltou de 509.000 operários em 1865 para 840.000 em 1890; na indústria mineradora, mantendo as mesmas datas de recenseamento, o número de trabalhadores saltou de 165.000 para 340.000; nas ferrovias esse salto é ainda maior: de 32.000 para 252.000 operários (Lenin, 1982b:316). A utilização de máquinas a vapor, um sinal de avanço da mecanização sobre a manufatura na grande produção capitalista, apresenta a mesma tendência: a potência total em cavalos de força (CV) saltou, em menos de 15 anos, de 114.977 CV (1875/1878) para 354.209 CV (1892), um incremento de mais de 100\% (Lenin, 1982b:322).

Para além de um retrato do desenvolvimento das forças produtivas rural e industrial, Lenin demonstrou que esse desenvolvimento produziu transformações profundas no panorama social e econômico da Rússia: formação de centros industriais em áreas rurais (Lenin, 1982b:355); expansão das linhas de comunicação, que cortavam as paisagens russas ao lado da expansão das linhas férreas (Lenin, $1982 b$ :347); crescimento do comércio exterior e interior; desenvolvimento da circulação mercantil e de instituições bancárias (Lenin, 1982 : 352); colonização de áreas fronteiriças em busca de matéria-prima (Lenin, 1982b:365). A partir de 1893, com a nomeação de Sergei Witte para Ministro das Finanças, a Rússia inicia um rápido e intenso processo de industrialização. Surge o "Sistema Witte", baseado em investimentos estatais

\footnotetext{
4 Lenin aqui considera o tamanho das unidades fabris a partir da quantidade de trabalhadores empregados. No quadro "As grandes fábricas da Rússia Europeia", essas são categorizadas como a) de 100 a 499 operários; b) de 500 a 999 operários; c) mais de 1000 operários.
} 
no setor de Bens de Capitais a partir do aumento de tributação sobre o campesinato e injeção maciça de capital estrangeiro. Entre as grandes obras de infraestrutura, destacou-se a construção da Ferrovia Trans-Siberiana, com 7.000 quilômetros de extensão e que ligava a rede ferroviária da Rússia Ocidental à costa do Pacífico. Entre os anos de 1890 e 1900 a produção de carvão subiu de 367 milhões de $p u d s^{5}$ para 995 milhões; a produção de ferro saltou de 106 milhões de puds para 367 milhões; a produção de petróleo quase triplicou: de 241 milhões de puds, a Rússia passou a produzir 632 milhões. A Rússia assim combinava as mais modernas técnicas fabris, concentradas em grandes centros populacionais, ao modelo agrícola mais primitivo e improdutivo da Europa.

Diferentemente dos narodistas, Lenin enxergou nesse processo de transformação da sociedade russa a força revolucionária e progressista do Capital, cuja universalidade lançava por terra as remanescências atávicas de uma sociedade que ainda carregava fortes traços feudais, justamente os elementos eslavófilos e particulares tão caros à Intelligentsia narodista. Não poderia ser outro o título que Lenin deu à última seção de sua obra: " $A$ 'missão' do capitalismo".

Lenin produziu assim o que muitos consideram a primeira e mais poderosa leitura da realidade socioeconômica da Rússia ao mesmo tempo em que encerrou o debate entre social-democratas e narodistas quanto à questão agrária. José Paulo Netto descreve esse trabalho como "a efetivação de um projeto global integrado de apreensão da dinâmica econômico-social de uma formação histórica particular, da identificação de suas tendências mais profundas, da determinação de seu movimento" (Lenin, 1982b:x). Tamás Krausz defende que a grande contribuição dessa obra foi combinar pela análise e crítica os problemas da diferenciação social entre os camponeses e a formação do mercado interno, lançando as bases da teoria marxista das formas sociais baseada na predeterminação econômica das estruturas sociais (Krausz, 2015: 82). Ainda que Lenin tenha definido os limites do debate entre narodistas e social-democratas, é necessário salientar que de modo algum

5 Pud é uma medida de peso utilizada na Rússia até a reforma de pesos e medidas de 1922 e que equivalia a 16,38 quilos. 
se encerrou o debate acerca da questão agrária. Esse debate se estende, sob novos contextos e roupagens, pelas primeiras décadas do século XX, atravessando mesmo o período formativo da URSS.

Para além da crítica ao narodchestvo, "O desenvolvimento da capitalismo na Rússia" possibilitou aos seus leitores apreenderem o movimento de expansão e desenvolvimento do Capital não apenas em sua dimensionalidade histórica, mas também em sua objetividade espacial. Sob a presença ubíqua da lógica mercantil, a própria paisagem fora reconfigurada de forma a atender as necessidades de acumulação: centros industriais se espalhavam pela cidade e campo; ferrovias, portos e estradas conectavam as zonas produtoras tanto aos grandes centros populacionais quanto ao mercado internacional, cujas cotações passavam a direcionar a produção de acordo com suas necessidades especulativas; o campo, tornado espaço produtor de mercadorias, subsumia-se à cidade, ao espaço urbano - se urbanizava. O tempo do mundo rural, marcado pelos ciclos naturais, era alijado em favor do tempo de rotação do Capital, desde a produção até sua realização, cujo único imperativo é realizar Valor, isto é, tornar lucro trabalho social não pago. A ruína do camponês não predeterminava tão somente o desenvolvimento do mercado interno, como também anunciava a formação do proletariado - em um primeiro momento rural, mas que se urbanizava em ritmo acelerado.

Harvey (2001 : 145), ainda que não trate do debate agrário russo datado na passagem dos séculos XIX e XX, ao refletir sobre o conceito de tempo-espaço relacional a partir da concepção cíclica de reprodução do Capital, nos permite vislumbrar na obra de Lenin essa categorização: sob a égide da reprodução de Valor, o espaço é ressignificado pelo processo revolucionário do Capital. Sua natureza universal, da mesma forma em que socializa as relações de produção e amplia as formas de trabalho, opera dialeticamente com seu caráter histórico-particular, que fragmenta saberes, submete o homem à técnica e cliva as relações produtivas, dividindo os homens entre produtores e proprietários. Esse processo trespassa todas as esferas da existência humana, tornando em produto - particularizando na forma de mercadoria - as dádivas da natureza e submetendo os diversos tempos da natureza ao tempo único do relógio, o tempo da rotação e reprodução do Capital. A dialética constituinte 
da alienação capitalista consiste assim na universalização de suas categorias particulares (espaço-produto, tempo do relógio, trabalho alienado) em relações e formas de produção particularmente universais, artificialmente naturais, ideologicamente eternas, em que o trabalho concreto é suplantado pelo trabalho abstrato, isto é, tempo de trabalho socialmente necessário (Harvey, 2011 : 141-145). O campo, enquanto espaço de vivência, espaço de realização do cotidiano dos trabalhadores, cede lugar ao urbano, cuja lógica opera menos a partir dos valores de uso provenientes da sociabilidade e mais a partir dos valores de troca cujas realizações regem a economia de mercado.

Ainda que não encerrem o debate sobre a questão agrária, as obras de Plekhánov e Lenin, bem como os debates empreendidos por esses, esgotam essa problemática para a social-democracia russa: o capitalismo é uma realidade e a desintegração da obshchina um processo irreversível. A industrialização e consequente urbanização da sociedade russa não era apenas uma realidade dada, mas um processo que, a despeito da violência que enseja o processo de desenraizamento do camponês, traria consigo a formação do futuro sujeito revolucionário, cuja existência é resultado direto das contradições inerentes ao Capital: o proletariado. O futuro caberia às cidades, ao desenvolvimento fabril e à classe operária. Esse debate e sua consequência direta - o fundamento teórico marxista que orienta a social-democracia russa - encontram-se presentes em "Estrela Vermelha", e sua descrição nos fornece um ponto privilegiado para perceber de que forma a questão agrária, que dialeticamente abriga o papel das cidades e da indústria, atua no esforço imaginário de Bogdánov para conceber a questão dos espaços e tempos da produção em uma sociedade desalienada, expressa na utopia marciana.

\subsection{A questão agrária em "Estrela Vermelha": A cidade e o campo em um mundo desalienado}

Bogdánov não participou diretamente do debate agrário que marcou profundamente a Intelligentsia radical nas duas últimas décadas do século XIX. 
Uma possível razão para isso - já apresentada no primeiro capítulo deste trabalho - repousa no fato de que, de acordo com sua autobiografia, Bogdánov afiliou-se tardiamente ao movimento social-democrata, reconhecendo-se como narodnik até 1896, ano em que, sob a influência do círculo social-democrata de Brusniêv, acabou por tornar-se marxista (White, 2018:15). No entanto, a questão agrária percorre grande parte da sua obra, seja em seus trabalhos anteriores, como em "Economia Política (Curso Popular)", seja em "Estrela Vermelha". Em "Economia Política (Curso Popular)", Bogdánov parece concordar integralmente com as críticas de Lenin e Plekhánov: o capitalismo é um fato inexorável que levará a desintegração do modo de vida campesino. Desenvolvido enquanto ministrava aula em círculos operários na cidade de Tula, Bogdánov partiu das diferentes formas de "valor de troca" descritas por Marx no primeiro volume d' "O Capital" - forma de valor simples; forma de valor total; forma de valor universal; e a forma de valor-dinheiro (Marx, 2013:125-145) - para descrever diferentes estágios de desenvolvimento das forças produtivas desde o comunismo primitivo, passando pelas sociedades escravistas e servis, culminando por fim na sociedade capitalista contemporânea. Nesse traçado o autor ainda tentou articular as diversas formas de organização política a partir do desenvolvimento das forças produtivas e as consequências sociais desse processo de desenvolvimento (Bogdanov, $1932: 15-85)$.

Bogdánov frisou, por exemplo, argumentos já utilizados por Lenin para demonstrar o processo de expropriação do campesinato de suas ferramentas a partir da socialização do trabalho sob a égide da economia mercantil (Bogdanov, 1932:167); a expansão da produção manufatureira em larga escala (Bogdanov, 1932:206); o crescimento do capitalismo industrial e a consequente desintegração da economia natural campesina (Bogdanov, 1932 : 210); e a subsunção da agricultura à demanda produzida pela indústria por matéria-prima (Bogdanov, 1932 :212). Em resenha publicada no periódico "Paz de Deus", Lenin teceu loas a essa obra, ressaltando a clareza e o rigor com que Bogdánov relacionou cada período de desenvolvimento econômico com as instituições políticas daquele momento histórico. Entre vários elogios, Lenin fez uma ressalva: a obra poderia ter buscado mais exemplos na própria 
história econômica da Rússia (White, 2018:20), uma tarefa que o próprio Lenin realizaria dois anos depois com a publicação de "O desenvolvimento do capitalismo na Rússia".

Ainda que tenha dado a tônica do debate entre as diversas frações da Intelligentsia russa, convém ressaltar que a questão agrária é parte constituinte de um problema maior: a configuração do espaço - e natureza - pela ação humana, estando essa ou não sob o controle dos seus agentes. De acordo com Harvey (2011 : 143), a transformação espacial em sociedades capitalistas se encontra menos sob o controle voluntário das sociedades que a produzem e mais sob determinação da lógica irracional do capital, que coloniza os espaços em favor de suas necessidades de reprodução ampliada. Ainda que Bogdánov não tenha lidado diretamente com a questão agrária em textos anteriores, ao propor em "Estrela Vermelha" um esforço imagético em descrever um futuro possível para o socialismo russo, as questões históricas desse sujeito são inevitavelmente tratadas. E não poderia ser de outra forma, uma vez que a organização racional do espaço e sua reconfiguração transicional é central no gênero literário utópico. Nessa obra Bogdánov apresenta sua solução para a dicotomia entre o campo e a cidade, solução que, como veremos, dialoga não apenas com seus fundamentos empiriomonistas e marxistas mas também com as tradições política e utópica da Intelligentsia russa.

Bogdánov credita às características geográficas de Marte diversos elementos determinantes para a particularidade do desenvolvimento histórico marciano. Ao questionar Menni sobre as línguas marcianas, Leonid aprende que os diversos dialetos marcianos acabaram por se amalgamar em uma única língua comum. Menni atribui como causa desse fenômeno diversos fatores naturais: a ausência de oceanos e cordilheiras, a existência de uma única placa tectônica, o tamanho reduzido da superfície marciana comparada à superfície terrestre, a difusão da literatura, e a gravidade reduzida, que possibilita o rápido deslocamento dos marcianos em solo. Para Menni esses fatores impediram que os marcianos se dividissem em nações, grupos étnicos ou linguísticos, identificados na obra como fundamentos das diversas divisões que afligem a humanidade terráquea. Ao descrever o desenvolvimento histórico primitivo dos marcianos, Leonid conclui que: 
"O curso da história em Marte foi em certos aspectos mais gentil que simples que o curso que se deu na Terra. Naturalmente houve guerras entre diferentes tribos e também luta de classes. No entanto, as guerras tiveram um papel minoritário da história marciana e cessaram precocemente, enquanto a luta de classes resultou em confrontos diretos menos frequentes e violentos que na Terra. (...) Escravidão era inteiramente desconhecida em Marte. Houve muito pouco militarismo em seu feudalismo, enquanto o capitalismo marciano superou a divisão entre estados-nação em um estágio precoce, produzindo nada comparável aos nossos exércitos modernos." (Bogdanov, 1984 [1908] :53)

Bogdánov exercita aqui a abordagem não-dialética que marcou sua obra e que acabou por qualificar a crítica que o marxismo russo fez dela posteriormente. Assim como em "Economia Política: Curso Popular", Bogdánov descreve o desenvolvimento histórico marciano de forma linear, ausente de contradições. A História marciana é um reflexo mais sereno e menos violento da própria história humana, ambas desprovidas de contradições, rupturas, longas durações e particularidades. Se as particularidades existem, assim o são devido a fatores extemporâneos e que se encontram fora da esfera de atuação dos sujeitos sociais. Ao contrário, esses acabam definidos por esses mesmos fatores. Retiram-se os acidentes geográficos e todas as línguas desaparecem; reduz-se a gravidade e as fronteiras são apagadas dos mapas. A história de Marte é o silenciamento da pluralidade, dos diversos devires históricos, das rotas possíveis e não tomadas. Nesse sentido, a obra de Bogdánov é utópica não somente porque pressupõe uma teleologia realizada; para além disso, é utópica porque anti-histórica.

Em "Estrela Vermelha" a natureza encontra-se em eterno confronto com o mundo social. Esse enfrentamento é, sob os olhos do autor, a força motriz que faz avançar o desenvolvimento histórico e social de Marte, assim como se dá na Terra. Marte, por razão de sua idade, vem há milhares de anos sofrendo um inexorável processo de desertificação, o que levou ao desaparecimento de seus oceanos e rios. Essa desertificação é o grande antagonista da utopia de Bogdánov e é contra ela que se lançam as forças tecnológicas da civilização marciana. Assim como Marx, Bogdánov considera que é na relação metabólica entre o homem e a natureza que se constitui o ser genérico, o humanamente natural (Marx, 2004 : 85). No entanto, tal relação não é dialética. Ela é, antes 
de tudo, antagônica. Como vimos anteriormente, essa abordagem da luta marciana contra o mundo exterior encontra-se de acordo com a concepção que Bogdánov apresenta para categorizar a natureza: o vasto campo da experiência laboral, onde se dá o confronto entre o trabalho social e o a matéria. Natureza, o repositório da infinitude de elementos neutros que se encontram em estado de caos, é categorizada como tudo aquilo que oferece resistência ao esforço empreendido; e trabalho é qualquer esforço lançado contra aquilo que resiste (Bogdanov, 2016 [1913] : 43).

Esse enfrentamento percorre toda a obra e é o ponto dramático central de "Estrela Vermelha". É a partir dele que Bogdánov oferece sua solução para a questão agrária: o avanço das forças produtivas - que sob a égide do capitalismo marciano se configura na lógica da reprodução ampliada do Capital - impulsionadas pelo confronto com o mundo natural, levou em um primeiro momento à dissolução do campesinato e posteriormente ao desaparecimento da propriedade privada da terra a partir de sua estatização. Menni explica esse processo ao fornecer para Leonid um breve resumo do processo de desintegração da propriedade rural:

\begin{abstract}
“(..) mas mesmo o desenvolvimento do capitalismo seguiu uma rota única que criou novas condições para a unificação política de todas as tribos e povos de Marte. Na agricultura, por exemplo, o pequeno campesinato foi expropriado em um estágio bastante precoce pela agricultura industrializada de larga-escala e toda a terra foi nacionalizada algum tempo depois." (Bogdanov, 1984 [1908] : 53)
\end{abstract}

Diferentemente de Lenin, Bogdánov não credita a desintegração do pequeno campesinato ao processo de formação do mercado interno, processo cujo desenvolvimento determina e é determinado pela expropriação dos meios de produção e consequente socialização do trabalho. O fator desestruturante desse campesinato é uma catástrofe ambiental, cujo agravamento leva à dissolução mesma da agricultura capitalista. É fundamental ressaltar que o desaparecimento da propriedade privada da terra ocorre como elemento interno ao capitalismo marciano e não a partir de suas contradições. Bogdánov buscou adequar ao que ele considerava lacunas da teoria marxista categorias sistêmicas e evolutivas, que se propunham a dar conta de processos, 
adaptativos e de longa duração, em contraponto à abordagem corrente de sua época, cuja análise se concentrava primariamente nos momentos de crises e nas relações antagônicas de produção. Retornaremos a essa questão no próximo capítulo.

O processo de desertificação não é responsável tão somente pelo desaparecimento da agricultura capitalista. Ele é o panorama que força o desenvolvimento das forças produtivas e é esse desenvolvimento que acirra as contradições entre as formas organizativas da civilização marciana e suas relações capitalistas de produção:

“...Em Marte, cuja situação (desertificação) já havia se tornado crítica 1000 anos atrás, uma vez que os oceanos encolheram, houve naturalmente um decréscimo paralelo da cobertura de nuvens e da precipitação, o que significou por sua vez que rios e fontes começaram a secar. A irrigação artificial tornou-se uma necessidade na maioria dos lugares. O que poderiam fazer pequenos agricultores independentes em tal situação?" (Bogdanov, 1984 [1908] : 56)

A primeira consequência da ruína do pequeno agricultor foi a concentração de terras. Conforme descreve Menni, apenas os grandes proprietários detinham capital suficiente para financiar os projetos de irrigação. O pequeno campesinato tentou organizar-se em cooperativas, que por sua vez tornaramse alvos fáceis para o capital pecuniário. Sob o peso de taxas de juros cada vez maiores, as cooperativas acabaram solvendo-se e caindo sob o controle econômico de seus credores, levando à proletarização de centenas de milhares de camponeses (Bogdanov, 1984 [1908] : 55). Através da descrição de Menni, podemos perceber a influência que a obra de Lenin exerceu sob Bogdánov. Esse debate é, em vários aspectos, uma chancela para os argumentos de Lenin expostos em "O desenvolvimento do capitalismo na Rússia".

O ponto central para o processo revolucionário marciano é a implementação dos grandes canais, fundamentais, de acordo com Menni, para atender as necessidades da regiões interiores do planeta. Menni descreve esse processo da seguinte forma:

"A época da escavação dos canais foi um período de grande prosperidade em todas as áreas da indústria e um período de profunda calma na 
luta de classes. A demanda por trabalho era tremenda e o desemprego desapareceu. Mas quando o grande projeto foi terminado, consolidando a colonização capitalista das antigas terras ermas, uma crise industrial explodiu, o que rompeu a paz social. O resultado foi uma revolução social, mas novamente o curso dos eventos foi relativamente pacifico. Greves eram a principal arma dos trabalhadores, enquanto os raros levantes que ocorreram estavam restritos a poucas áreas, quase exclusivamente agrícolas. Os proprietários recuaram passo a passo perante o inevitável e mesmo quando o governo caiu nas mãos do partido dos trabalhadores, os derrotados não tentaram impor seus interesses pela força." (Bogdanov, 1984 [1908] : 57)

A Revolução de 1905 foi, em diversos aspectos, um evento-chave para compreender o desenvolvimento das posições táticas e filosóficas de Bogdánov. A partir de sua experiência como representante do POSDR junto ao Comitê Central do Soviete de São Petersburgo, Bogdánov reorientou diversos de seus posicionamentos em relação às posições táticas da facção bolchevique. Essa reorientação acabou por lhe colocar em rota direta de colisão com Lenin, ao rechaçar a participação de deputados bolcheviques eleitos na $3^{\circ}$ Duma e defender o aprofundamento das táticas de propaganda e atividades ilegais do Partido. Bogdánov acreditava não somente que a derrubada do czar ainda era possível a partir do ímpeto revolucionário que já arrefecia em 1908, mas também que a participação na Duma do czar era um atestado de traição da Intelligentsia revolucionária frente aos trabalhadores (Yassour, 1981:7). Bogdánov bebe da experiência de 1905 para descrever a revolução socialista marciana e é a partir desse ano que o autor constrói seu aparato narrativo para dialogar com a recepção dos trabalhadores a quem se dirige em "Estrela Vermelha". A crise industrial que seguiu à construção dos grandes canais e que serviu como estopim para a revolução marciana carrega diversas semelhanças com o papel que Mikhail Nikolaevitch Pokróvski, um dos mais importantes historiadores marxistas daquele período e membro fundador da facção bolchevique, dedicou à crise econômica que se abateu sobre a indústria russa após o término da Ferrovia Transiberiana.

Em sua obra "Causas Econômicas da Revolução Russa", Pokróvski discriminou o boom industrial da última década do século XIX em dois grandes setores: as indústrias têxtil e metalúrgica. De acordo com o autor, 
entre os anos de 1889 a 1900, o aumento de fusos na Europa foi de $33 \%$ frente ao aumento de $76 \%$ na Rússia. A fundição de aço nos EUA e na Alemanha aumentou respectivamente $50 \%$ e $72 \%$ contra um aumento de $190 \%$ na Rússia. Esse cenário de expansão buscava atender ao crescimento do mercado interno, tanto a partir da proletarização das massas camponesas - atendido prioritariamente pela produção de roupas e tecidos - quanto à indústria de bens de capital, seja a produção de ferramentas voltadas à burguesia rural, seja o intenso programa de expansão da malha ferroviária. Somente a Ferrovia Transiberiana, cujo projeto se iniciou em 1887, foi responsável por quase a metade do crescimento da indústria metalúrgica russa e empregou $66 \%$ do operariado russo, que assistiu durante sua construção a sucessivos aumentos salariais e a uma crescente organização sindical (Pokrovski, 1944:54).

O término das obras da Ferrovia Transiberiana em 1901 levou a uma severa crise na indústria metalúrgica russa. Tal crise foi acompanhada pela redução do número de operários empregados e pela queda nominal do salário real. Ao mesmo tempo, o Estado czarista, amplamente endividado junto ao setor financeiro internacional, elevava os tributos sobre as classes trabalhadoras, cujo fardo era acrescido por aumentos sucessivos do preço do trigo, controlado pelo valor das bolsas internacionais (Pokrovski, 1944:59). Pokróvski identificou três fases distintas do desenvolvimento político do proletariado russo entre as últimas décadas do século XIX e os eventos que serviram de estopim para a Revolução de 1905: em um primeiro momento, entre os anos 1880 e 1890, o desenvolvimento de greves pacíficas, cujo núcleo central é composto por operários da indústria têxtil e em que predominam os interesses profissionais (Pokrovski, 1944 :61); já a partir de 1903, o núcleo do movimento grevista passou a gravitar em torno dos metalúrgicos, que incorporam às demandas profissionais elementos da luta política compartilhada com diversos setores da Intelligentsia e expõem o esgotamento do setor de indústria pesada (Pokrovski, 1944:69); e, por fim, a explosão revolucionária de dezembro de 1905, que armou e unificou a pauta do movimento operário de diversos distritos industriais espalhados por toda a Rússia e que resultou no surgimento dos sovietes em diversas capitais provinciais, expropriando de fato o poder autocrático da burocracia czarista em diversas esferas. A principal 
arma do proletariado foram as greves. Pokróvski estima que, no ano de 1905, as greves perfizeram um total de 2.830.000 grevistas, um número superior à soma dos grevistas americanos (660.000), alemães (527.000) e franceses (438.000) entre os anos de 1894 a 1908 (Pokrovski, 1944:96).

A revolução socialista foi antecedida pela expropriação do campesinato e por uma grande crise do setor de infra-estrutura, cujos sujeitos históricos encontraram na prática grevista sua arma principal contra a ordem capitalista vigente. A revolução marciana de Bogdánov decerto sorveu em sua descrição importantes elementos causais propostos por Pokróvski. A relação entre os dois autores é mais do que meramente textual. Pokróvski foi um importante membro do círculo vperedista, grupo de intelectuais bolcheviques que romperam com Lenin em 1909. Pokróvski, ainda que marxista ortodoxo, alinhou-se a Bogdánov e viajou com ele para fundar as escolas do POSDR em Capri e Bolonha, locais onde ministrou aulas de História Econômica e História da Rússia entre 1911 e 1913 (Marot, 1990 : 247).

Esse movimento de evolução da sociedade marciana, quase desprovido de solavancos e que segue um caminho suave em direção ao socialismo, reflete o caráter funcionalista do marxismo bogdanoviano. Ao preterir a análise dialética em favor de uma abordagem empírico-positivista, Bogdánov acabou por ressaltar processos de continuidade, de transformação lenta e gradual, dotados de fatores evolutivos. Essas características já presentes em "Estrela Vermelha" antecipam postulados importantes de sua ciência organizacional universal, a Tektologia. Retornaremos a essa questão epistemológica no próximo capítulo.

O desaparecimento da campo enquanto espaço de atividade socialmente especializada não determina necessariamente, em "Estrela Vermelha", a supremacia do espaço urbano. Ainda que não haja uma descrição detalhada das cidades marcianas, Bogdánov descreve diversas de suas características no decorrer da obra. É possível, assim, reconstituir uma fotografia do espaço urbano em "Estrela Vermelha" e, a partir dessa imagem, estabelecer diversos diálogos com a tradição utópica russa, com os diversos movimentos urbanísticos russos que atuaram naquele momento histórico, e, por fim, com o recorte epistemológico que caracteriza a forma particular de marxismo 
defendida por Bogdánov em sua obra. A partir dessa discussão será possível delinear a posição de Bogdánov referente à desalienação do espaço, presente principalmente no campo acadêmico da Geografia. A partir da leitura da obra, podemos classificar a organização espacial marciana em quatro níveis descritivos: individual, regional, produtivo e global. Deixaremos o nível produtivo e global para o capítulo final, dada a complexidade que apresentam no pensamento de Bogdánov. Daremos ênfase neste momento ao nível da residência e da cidade.

\subsection{Cidade-uso, cidade-produto}

Ao chegar em Marte, Leonid se hospeda no apartamento de Menni, localizado em um assentamento fabril. Esse assentamento é composto por um complexo planejado de residências e indústrias, cujo centro físico e econômico é um gigantesco laboratório químico, localizado em seu subterrâneo:

"A parte do assentamento ${ }^{6}$ localizada na superfície estava espraiada por sobre um parque que cobria por volta de 10 quilômetros quadrados e que consistia em centenas de apartamentos para os trabalhadores do laboratório, uma grande assembleia, o depósito cooperativo e o centro de comunicações, que conecta o assentamento com o resto do mundo." (Bogdanov, 1984 [1908] : 59)

Nessa curta descrição já é possível verificar algum posicionamento de Bogdánov em relação ao debate intelectual russo que se debruça sobre as questões do espaço. O complexo habitacional localiza-se em meio a um parque, enquanto a fábrica está restrita a um complexo subterrâneo. Ao descrever a residência de Menni, Leonid observa que: "todas as áreas de trabalho (...) localizavam-se no andar térreo, cujas largas janelas admitiam a constante luz vermelha refletida nas folhagens das árvores no parque" (Bogdanov, 1984 [1908]: 60).

O equilíbrio tênue entre a privacidade e vida pública sempre fora uma preocupação constante entre a Intelligentsia socialista pré-revolucionária

6 O uso do termo "assentamento" acaba por ocultar o caráter citadino da paisagem, sugerindo uma certa precariedade. Na obra original Bogdánov se utilizou do termo gorodka (pequena cidade) e é a partir desse termo que analisaremos a descrição. 
e, posteriormente, entre os planejadores urbanos soviéticos. Em "O que fazer?", Vera Plavlovna, protagonista do romance de Nikolai Tchernichevski, é apresentada em sonhos ao futuro socialista. Em um vasto campo de trigo, ergue-se um palácio feito de cristal e alumínio, habitado por um sem número de homens e mulheres. Esses labutam nos campos e, ao retornarem para o palácio, ceiam em grandes mesas coletivas (Tchernichevski, 2013:412-416). Assim como nos falanstérios de Fourier, a vida privada é indivisível da vida comunal. Nada se oculta através das paredes de cristal. Tchernichevski faz de sua visão utópica um retrato do super-realismo que defendeu em sua tese: o belo é a vida e é a vida e suas transformações que devem guiar a arte e a sociabilidade. O artista não é um ser apartado de sua obra; ele é a obra que produz e sua obra reflete a forma como ele atua no mundo, da mesma forma que é sua vida que guia sua produção artística. Não há espaço para hiatos entre o viver público e o viver privado (Branco, 2014:312).

A translucidez dos muros do falanstério, imaginado como extrapolação de um mundo liberto das relações de opressão, também serviram como motif para a produção de poderosos exercícios de opressão, em que a inexistência de privacidade é produzida não pela transparência das relações sociais, mas pela constituição de um panóptico onisciente e onipresente onde quaisquer segredos são criminalmente tipificados. Dostoiveski, um retinto e genial eslavófilo, enxergava no Palácio de Cristal de Londres um símbolo da desumanidade industrializada, que dividia os homens entre ricos lascivos e pobres bêbados e sectários (Suvin, 1971:143). Talvez a mais poderosa distopia dos anos formativos da Rússia Soviética seja "Nós" ("Mы") de Ievguêni Zamiatin. Publicada em 1923, "Nós" retrata uma megalópole inteiramente construída em vidro, cujos cidadãos - nomeados com números de série - têm cada aspecto de suas vidas pessoais vigiado e controlado por um Estado totalitário (Zamiatin, 2017). O Palácio de Cristal de Tchernichevski é também um testemunho da relação dialética entre os sonhos utópicos e os pesadelos das distopias.

O sonho de Vera Pavlovna é a realização plena do socialismo agrário dos narodistas e "O que fazer?" influenciou marcadamente as gerações revolucionárias posteriores. A vida comunal, marcada pela hegemonia da 
sociabilidade sobre o espaço privado, encontrava suas raízes na própria obshchina e era por isso um tema comum entre os escritores russos na passagem dos séculos XIX e XX. A obshchizhitie ("общижитие") (morada comunal) é o espaço de vivência cotidiana na peça "Mir" (1904) e no romance "A República da Cruz Sulista" (1907) do poeta simbolista Valeri Briúsov (Briusov, 1919). A partir da Revolução de 1917, as possibilidades transformadoras da obshchizhitie seduziram uma geração de urbanistas, que incorporaram em seus projetos uma série de inovações. O objetivo não era tão somente dar conta do enorme déficit populacional nas grandes cidades, causado por gigantescas ondas migratórias, mas também revolucionar os hábitos existentes e desenvolver novas formas de sociabilidade. Surgem nos anos iniciais do nascente Estado Soviético diversos projetos de falanstério, como os de Tverskoi e Burishkin (1921) e os complexos habitacionais de Moscou (1922), desenhados por Leonid Vesnin. Esses consistiam em diversos complexos habitacionais com áreas de serviço interligadas e conectados por uma ampla área de lazer. O objetivo era potencializar o tempo de convívio entre seus habitantes, bem como libertar as mulheres das tarefas domésticas, um projeto caro a Alexandra Kollontai, então comissária do Bem-Estar Social e fundadora do Zhenotdel ${ }^{7}$ (Stites, 1989 : 202). A despeito das dificuldades de distribuição de alimentos durante a Guerra Civil Russa, os restaurantes comunais foram uma prova de sucesso desses primeiros projetos urbanísticos: em 1920, 90\% da população de Petrogrado se alimentava comunalmente; em Moscou, essa percentagem chegava a 60\% (Porter, 1980:319).

Em "Estrela Vermelha", Bogdánov tentou prover equilíbrio entre as necessidades individuais de privacidade e o esforço coletivo de sociabilidade: A residência de Menni ainda é uma residência nuclear, individualizada. Sua arquitetura é indistinguível das residências ao redor, no entanto sua planta aparenta ser ordinária. De forma a tentar diferenciar o espaço privado de Menni das residências terráqueas, Bogdánov descreve diversas inovações tecnológicas, como o "fonótipo", que transcreve gravações, ou telefones conectados

\footnotetext{
Zhenotdel ("Женотдел"), acrônimo para "Seção das Mulheres", foi um bureau hierarquicamente centralizado e submetido executivamente ao Comissariado do Bem-Estar que tinha por objetivo operacionalizar o processo de emancipação feminina e atrair as mulheres para a causa socialista. Para mais informações, ver Porter (1980).
} 
a aparelhos visuais que transmitiam a imagem de quem se posicionasse em sua frente.

Ainda que a casa enquanto espaço nuclear para o exercício da individualidade seja a forma comum de moradia, essa não é a única. Bogdánov reserva a vivência socializada para grupos etários específicos. Ao visitar a colônia das crianças, Leonid descobre que as crianças marcianas vivem em obshchizhitie. Ali convivem crianças de diversas idades, acompanhadas por alguns poucos adultos que atuam como educadores. Ao questionar a quase ausência de adultos para Nella, a supervisora que o acompanha na visita, Leonid aprende que os poucos adultos presentes são aprendizes de educadores e pais. Ele descobre então que há residências individuais na colônia para pais que queiram viver com os filhos e crianças que desejam maior privacidade (Bogdanov, 1984 [1908] : 71). Bogdánov justifica assim um posicionamento intermediário entre a valoração do espaço individual-burguês e a subsunção do indivíduo em formas falansterianas e comunais, fundamentais para a constituição de novas experiências de sociabilidade e que servem de base para as experiências dos socialistas marcianos.

As grandes cidades estão presentes em Marte, mas Bogdánov não dedicou espaço em sua obra para descrevê-las. Supomos que essa ausência pode se relacionar com o caráter pedagógico e propagandístico de "Estrela Vermelha", cuja realização tinha como público os trabalhadores da Rússia e não seus intelectuais. A pequena cidade, que comporta algumas centenas de trabalhadores, se aproxima em termos de tamanho e complexidade administrativa à obshchina, unidade fundamental de sociabilidade desses trabalhadores. Ainda que centenas de milhares de operários vivam nos subúrbios fabris de Moscou, Ecaterimburgo e São Petersburgo, Bogdánov tem plena consciência de que esses ainda são camponeses, cuja experiência social, ainda que desgarrada do campo, remete-os para a Mir. Em um importante estudo sobre as organizações trabalhadoras russas pré-revolucionárias, Nikolai Mikhailov identificou diversos elementos presentes na vida laboral dos operários russos que remetiam diretamente às tradições campesinas da obshchina, como a punição ostracizante aos maus trabalhadores e a luta corporativista pela restrição às vagas de trabalho a operários com origem em determinado local (Mikhailov, 
2008: 30). São esses trabalhadores, que vivem em um estado de sociabilidade ambíguo entre o campo e a cidade, que formam o grupo social para o qual Bogdánov se dirige.

Como vimos em citação anterior, o assentamento de trabalhadores do laboratório químico onde trabalha Menni localiza-se em meio a um parque, cujas as residências são iluminadas pelo reflexo do sol sobre as forragens (Bogdanov, 1984 [1908] : 59). Para além dessa breve descrição, Bogdánov nos fornece uma imagem mais precisa da paisagem urbana quando descreve a colônia de crianças, um centro educacional que se encontra presente em todas as cidades marcianas:

"Grandes edifícios de dois andares com os ja conhecidos tetos azuis se espalham por entre jardins com córregos, lagoas, áreas para brincadeiras e ginástica, campos de flores e jardins de ervas medicinais, além de pequenas casas para animais e pássaros." (Bogdanov, 1984 [1908]:69)

O caráter idílico das cidades marcianas também é ressaltado na descrição que Leonid faz do museu de arte, em companhia de Nella, pedagoga e mãe de Netti:

"O museu se localizava em uma pequena ilha, no meio de um lago, conectado às margens por meio de uma pequena ponte. A construção retangular, cercada por um jardim cheio de fontes e camas de flores azuis, brancas, negras e verdes, era luxuosamente adornada por fora e banhada de luz por dentro." (Bogdanov, 1984 [1908] :74)

Não há na paisagem urbana de Marte quaisquer máculas produzidas pelo processo anárquico de colonização do espaço pelo Capital. O laboratório de Menni é subterrâneo e seus trabalhadores vivem em meio a um parque. O espaço onde são educadas as crianças amalgama espaços humanos cuidadosamente planejados e elementos da flora e fauna marciana; o museu é cercado por flores e fontes e nos faz pensar em um quadro impressionístico de Monet. O espaço natural se funde ao espaço urbano. Bogdánov afasta na descrição que faz de uma fábrica pesada todos os traços que determinam o caráter insalubre da produção fabril de seu tempo: 
"A fábrica era completamente livre de fumaça, fuligem, odores e poeira. As máquinas, banhadas em uma luz que iluminava tudo (...) operavam metodicamente sob o ar fresco, cortando, serrando, aplainando e perfurando gigantescas peças de aço, alumínio, níquel e cobre." (Bogdanov, 1984 [1908] : 201)

Podemos perceber na descrição que Bogdánov faz do espaço urbano um ponto de interseç̧ão com a hostilidade e desconfiança que a Intelligentsia russa dedicou historicamente às cidades modernas. Bogdánov parece concordar com Tolstói. Não há espaço no comunismo avançado para as "horrendas chaminés das grandes fábricas". Essa ojeriza é um elemento constituinte da tradição revolucionária russa e adentrou as décadas iniciais do Estado soviético. O medo das cidades como fonte corruptora da alma russa sempre correu forte entre os eslavófilos, que viam nas cidades o caos inerente à modernidade ocidental. As cidades - sempre pensadas a partir dos grandes centros urbanos ocidentais - eram vistas como ninhos de criminalidade, dissidência, pobreza, doenças e vícios. O ódio eslavófilo ${ }^{8}$ a tudo que é citadino encontrava-se presente tanto em meio à nobreza e setores mais reacionários da sociedade russa quanto na própria Intelligentsia radical do século XIX. Para aqueles as cidades carregam dentro de si a sedição que varreu a Europa em ondas revolucionárias e regicidas; para esses, as cidades são centros de pobreza e injustiça social e que trazem consigo todas as tragédias do capitalismo.

Exemplos de condenação moral à vida urbana proliferam na tradição literária da Intelligentsia. Podemos citar a título de exemplo a obra "Viagem de São Petersburgo a Moscou" (1790) de Aleksandr Radishchev, importante autor iluminista e considerado um dos precursores da Intelligentsia radical, que descreve as cidades como antros insalubres e imorais (Radishchev, 1964). Entre os populistas essas críticas eram ainda mais frequentes: Sofia Perovskaya, personalidade proeminente do movimento "Narodnaya Volya", culpou os estímulos artificiais da vida urbana pelo amadurecimento sexual precoce

\footnotetext{
8 É importante ressaltar que a "eslavofilia", i.e. a crença no caráter único do povo russo, cuja particularidade projeta unicidade tanto à sua história quanto aos possíveis devires, não é um termo politicamente carregado. Seu significado flui de acordo com as diversas conjunturas históricas que o invoca para legitimar ou deslegitimar diversos projetos políticos. É essa dubiedade que Lenin ataca em " $A$ Herança que renunciamos" ao apontar que a eslavofilia aproxima os narodistas dos setores autocráticos russos e nessa aproximação acabam por rejeitar a herança iluminista das gerações radicais das décadas de 1830 e 1840 .
} 
das meninas; Nikolai Zlatovratski via as cidades como "encarnações de forças sinistras". Bakunin acreditava que as cidades não mereciam nada menos que a total destruição (Stites, 1989 : 192).

Existe uma tradição "urbanófoba" na literatura de FC russa que foi pouco estudada e que nos permite refletir sobre a impressão de seus autores sobre o espaço urbano. Talvez a obra inaugural da FC russa seja "Do ano 4338: cartas de São Petersburgo", de Vladimir Odoiévski. Nessa obra Odoiévski apresenta uma grande megalópole sem nome, que veio a existir a partir da conurbação entre São Petersburgo e Moscou. Odoiévski descreve uma cidade idílica - bastante parecida com as cidades marcianas - e se utiliza dessa cidade para descrever a superação do debate entre eslavófilos e ocidentalistas. Sua cidade é adornada com várias maravilhas tecnológicas, porém tal cidade somente é possível de existir na Rússia, cuja ortodoxia garantiu a sobrevivência do Estado enquanto o resto da Europa caiu um ruínas (Odoievski, 2007). Alguns anos depois, Vladimir Taniêev, em sua obra utópica "Estados Comunistas do Futuro" (1879), vislumbrou um futuro de comunas agrárias autogestionadas, organizadas em Federações. Cada comuna teria 2000 habitantes e as cidades teriam funções meramente administrativas, sem residentes fixos (Stites, 1989 : 193). Já no século XX, a ficção russa foi inundada por obras antiurbanas. Podem ser citadas a obra "A Cidade Cruel" (1907), de Pavel Dnieprov, que retrata São Petersburgo como um bloco de gelo cujo interior queima com luxúria; e os movimentos artísticos dos "socialistas mujiques" e "poetas citas", que condenavam as cidades em favor de uma visão idílica do campo. Sergei Iesênin referiu-se às cidades como "um labirinto onde os homens perdem sua alma". Alexander Blok, Pilniak e Ivanov-Razumnik projetavam em seus poemas a cidade como um espaço de solidão e ausência de comunidade (Stites, 1989 : 193).

A hostilidade para com a urbanidade capitalista, temperada por uma tradição de nostalgia bucólica, se encontrava nas raízes do socialismo russo, cindido entre o apreço pela capacidade produtiva das cidades e terror pelos males sociais do industrialismo; pelo desprezo pela "idiotia" do campo e desejo por uma vivência ditada pelos ritmos da natureza (Stites, 1989 : 194). Depositário dessa tradição, Bogdánov, em "Estrela Vermelha", tentou ope- 
rar a fusão entre os aparelhos urbanos e uma natureza cuidadosamente domesticada. Sua solução narrativa nos remete à teoria arquitetônica das cidades-jardins, bastante em voga nas primeiras décadas do século XX. A ideia de cidade-jardim originou-se a partir da obra de Ebenezer Howard, "Tomorrow: A Peaceful Path to Real Reform", de 1898, e depois reeditada sob o título "Garden Cities of Tomorrow", em 1904. Howard propôs em sua obra uma reforma radical dos espaços urbanos como resposta ao rápido processo de êxodo rural em decorrência da industrialização e consequente inchaço das cidades. Esse processo levava à especulação do valor imobiliário em prejuízo da comunidade, estimulando a favelização e isolamento dos munícipes, além da acentuada flutuação nos preços dos alimentos que produziam em sua época seguidas ondas de fome (Batchelor, 1969 : 185).

A partir da tradição utópica socialista de Fourier, Owen e Betham, Howard apresentou como solução o planejamento de cidades demograficamente delimitadas a 32.000 habitantes, conectadas por redes de transporte e comunicações e cercadas por um cinturão verde, que limitaria o crescimento físico do espaço urbano ao mesmo tempo em que forneceria alimentos à população citadina. Essa zona produtiva se basearia na propriedade pública da terra e garantiria autossuficiência para o centro urbano (Batchelor, 1969 : 195). A cidade seria constituída por seis grandes vias radiais, que circundariam um grande parque de cinco acres e, na circunferência interna se localizariam centros comerciais, teatro, biblioteca, hospital, sala de concertos, atividades de serviços e um palácio de cristal, centro da administração municipal. A circunferência externa seria dividida em seis grandes bulevares concêntricos, onde se distribuiriam ao redor zonas comerciais, industriais e residenciais. Em volta da cidade haveria um cinturão verde de 5000 acres, onde morariam mais 2000 habitantes (Batchelor, 1969 : 197). As cidades-jardim seriam conectadas por meio de vias a um centro urbano maior que serviria de " $h u b$ " entre as diversas cidades e forneceria atividades produtivas mais especializadas, coordenando de forma planejada as vocações das cidades a ela conectadas (Batchelor, 1969 : 198).

Pelos motivos vistos anteriormente, o movimento da cidade-jardim ressoou junto aos anseios da intelectualidade socialista e povoou a imaginação dos primeiros planejadores urbanísticos soviéticos. Importantes nomes do 
socialismo russo, notadamente entre narodistas e anarquistas, produziram na primeira década do século XX seus próprios projetos. Nomes como Piotr Kropotkin em "Campos, fábricas e oficinas; ou, indústria combinada com agricultura e trabalho intelectual com trabalho manual." (1898) e Aleksandr Tchayanov em "A jornada do meu irmão Aleksei à utopia campesina" (1906) produziram elaboradas utopias urbanas no afã de superar a dicotomia entre o campo e a cidade (Stites, 1984:144). Bogdánov, com sua obra "Estrela Vermelha", é uma personagem dentro dessa tradição.

Dificilmente podemos descrever Bogdánov como um teórico da revolução. Outros revolucionários, como Lenin e Trotski, em muito superaram Bogdánov em qualidade e profundidade analítica quando se trata de analisar o momento histórico em suas contradições. Em parte devido ao caráter positivista de seu pensamento, Bogdánov dedicou suas preocupações para o interregno entre a velha sociedade capitalista e a futura sociedade comunista. A transformação da velha ordem era para ele a superação da condição alienada do homem, a qual via como fruto da causalidade abstrata burguesa, originada das relações de produção capitalistas e que fragmentava o mundo natural e - por consequência - a consciência humana. Apenas pela superação dos fetichismos será possível à humanidade parir um novo mundo, uma sociedade de homens desalienados.

É possível vislumbrar essa preocupação em "Estrela Vermelha". Na velha disputa entre o campo e a cidade fica claro que, a despeito da natureza domesticada das cidades-jardins, o espaço hegemônico marciano é urbano. No entanto a cidade marciana é radicalmente diferente das cidades terrestres. Sua espacialidade está subsumida aos usos sociais que seus habitantes fazem dela; as cidades de Marte provêm tão somente valores de uso: em Marte não há mercadorias e, uma vez que não há produção de não-valores de uso, não há valor de troca. A sociedade marciana é amonetária, pois na superação do fetichismo, perde-se qualquer sentido na formação social de uma mercadoria equivalente universal. Não iremos nos aprofundar agora na organização produtiva de Marte: essa será uma tarefa para o próximo capítulo. No entanto é importante ressaltar que Bogdánov vislumbrou na superação do fetichismo da mercadoria não apenas uma transformação radical 
das formas produtivas, mas também a descolonização do espaço. Esse passa a atender não mais à lógica da reprodução ampliada do Capital, mas às necessidades da sociedade marciana. O trabalho, liberto da mediação contraditória entre trabalho assalariado e propriedade privada, deixa de ser fim-em-si e readquire sua natureza humanizadora. Os marcianos realizam-se enquanto seres genéricos por meio do trabalho que, na condição desalienada, não diferencia-se da arte. O caráter reificante do trabalho assalariado, a partir de um novo nível organizacional - tektológico - desaparece e com ele a dicotomia entre a arte como atividade desalienada e trabalho como atividade estranhada. Trabalho é Arte. Arte é Ciência. Ciência é Trabalho. Uma vez que Bogdánov é considerado o fundador teórico do Proletkult (Sochor 1988:8, Jensen 1978:6, Biggart 1987:172, Mally 1990:xxiii, Wark 2015:72), não podemos nos furtar a deixar de discutir o papel da arte em seu pensamento - mesmo que brevemente - e como ela se relaciona dialeticamente com as tradições intelectuais russas e de que forma se expressa na cidade e sociedade marcianas.

\subsubsection{A arte proletária e a tradição radical}

Em artigo intitulado "Criticismo da Arte Proletária ", Bogdanov (1923) apresentou uma definição estruturalista de arte: arte é toda atividade criativa, seja ela realizada elementarmente pela natureza, seja ela realizada sistematicamente pelo homem - que produz a partir de elementos neutros formas organizadas através de um princípio regulatório. No processo organizacional da vida, a mutabilidade cria constantemente novas formas de vida a partir de espécies existentes. Esse processo é então regulado pela "Seleção Natural" que preserva as formas de vida mais adaptadas. A produção artística, de acordo com Bogdánov, segue o mesmo princípio: a partir da experiência $^{9}$, o artista opera novas combinações de elementos para compor formas organizacionais cada vez mais harmoniosas. Essas combinações são por sua vez "reguladas" pela consciência do artista por meio do processo autocrítico (Bogdanov, 1923 : 344). A partir de uma escala social, a sociedade

\footnotetext{
9 Experiência em seu sentido bogdánoviano, i.e a totalidade social-natural que expressa a existência objetiva-social-física/subjetiva-individual-psíquica dos homens. Ver capítulo 2
} 
atua como elemento regulador da arte através da criticismo, que "aceita ou rejeita as obras inseridas como elementos dentro de seu sistema e apoia ou extermina novas correntes artísticas" (Bogdanov, 1923: 344). Bogdánov estabelece o criticismo como uma ferramenta reguladora que atua a partir do ponto de vista de um determinado coletivo e que, em uma sociedade de classes, corresponde a uma ou outra classe.

Bogdánov lança essas categorias como fundamentos para exercer no artigo fortes críticas às diversas correntes artísticas que se desenvolvem no interior do Proletkult. Para Bogdánov, a função da organização não é tão somente expressar a arte produzida pelo proletariado e Intelligentsia revolucionária, mas principalmente é prover a classe proletária de seu criticismo, isto é, sua visão de mundo, assentada nas bases organizacionais dessa classe: a cooperação, camaradagem e coletivismo. Suas críticas se assentam no fato de que a arte proletária reproduzia ainda elementos das artes campesina e burguesa, por sua vez prenhes de individualismo, romantismo e proprietarianismo. Como resultado essa arte era ainda uma produção que carregava as "marcas do velho mundo", profusa em chauvinismo, individualismo e heroísmo. Em sua crítica ao heroísmo como elemento constituinte da arte agitprop, Bogdánov enxergou ali uma tendência em glorificar membros da Intelligentsia em detrimento do papel protagonista da classe operária. Para ele, o herói deve ser reconhecido senão como "... a personificação das forças da coletividade, como uma expressão de sua vontade, como um apóstolo de seus ideais" (Bogdanov, $1923: 348)$.

A dimensão do grande coletivo está presente em diversas partes de "Estrela Vermelha" e se expressa na arte marciana. Durante visita ao museu, ao contemplar os monumentos, Leonid os divide em monumentos pré-socialistas, dedicados a personagens e grandes heróis; e monumentos contemporâneos, cuja elaboração: "é dedicada apenas a importantes eventos, como a primeira tentativa de chegar à Terra, à erradicação de uma epidemia fatal ou mesmo à descoberta de um novo processo para decompor e sintetizar elementos químicos" (Bogdanov, 1984 [1908] :77). No capítulo intitulado "O Povo", Leonid discute com Netti sobre o gênio de Menni, cujos cálculos permitiram a viagem interplanetária e o classifica como um pioneiro. Netti lhe responde 
que Menni:

"teve à sua disposição a experiência acumulada pelas gerações que o precederam e ele baseou cada passo de seu trabalho nessa experiência. (...) Suas conquistas são a contribuição última para a vida e a vida se desenvolverá para sempre." (Bogdanov, 1984 [1908] : 43)

Bogdánov rejeita quaisquer distinções de mérito dentro do coletivo. Não há diferença entre os trabalhadores marcianos, a não ser a diferença quantitativa que se relaciona ao montante de experiência organizada que cada um deixa para as gerações posteriores. Essa concepção é completamente estranhaa para Leonid. Bogdánov faz aqui uma crítica ao culto da personalidade presente mesmo na Intelligentsia socialista, eivada de individualismo burguês. Leonid não aceita tal suposição e questiona se Marte não preserva seus heróis. Netti responde então que "[a] humanidade não precisa de símbolos mortos que derivam de um indivíduo que já não existe. Nossa ciência e arte preservam impessoalmente as conquistas coletivas de todos" (Bogdanov, 1984 [1908] : 44).

Bogdánov defende uma arte em que o conteúdo e a forma estejam perfeitamente alinhados uma vez que "[a] arte deve, em primeiro lugar e sempre, ser perfeitamente sincera e verdadeira, pela simples razão de que ela é um fator organizador da vida" (Bogdanov, 1923:352). A partir dessa constatação, Bogdánov conclui que o criticismo da arte proletária deve perseguir um único objetivo, qual seja, a harmonia entre forma e conteúdo: "Passo a passo, nosso criticismo criará uma nova teoria da arte, que incluirá também todas as variedades de experiência do velho criticismo, mas revisado e sistematizado na base de um ponto de vista organizacional universalmente superior" (Bogdanov, 1923:354). Esse novo criticismo deverá guiar o artista na sua relação com arte não apenas como seu produtor, mas como alguém que é herdeiro de incontáveis gerações que o precederam. Com essa herança vem também a responsabilidade que cabe a cada artista como organizador das forças da experiência de um grande coletivo. O papel do criticismo é regular a vida social da arte não apenas em seu aspecto criativo, mas também em sua percepção. Cabe ao criticismo explicar às massas de que forma essa pode incorporar a arte no arranjo de suas vidas (Bogdanov, 1923:356). A arte deve servir à vida como princípio organizativo. 
Essa visão funcionalista da arte que a transforma em "espelho" da vida aquilo que Bogdánov define como sociomorfismo ${ }^{10}$ - e de seu papel pedagógico encontra-se descrita em "Estrela Vermelha". Em sua visita ao Museu de Arte, Leonid, ao perceber que as estátuas humanas produzidas em períodos anteriores da história marciana eram todas monocromáticas, diferentemente das obras contemporâneas, pondera que:

“...os desvios da realidade não podem ser elementos necessários à arte. Eles são mesmo anti-estéticos quando empobrecem a recepção por parte do observador. Esse é o caso com esculturas uniformemente coloridas, uma vez que a idealização concentrada da vida que constitui a arte é reduzida em vez de ressaltada por tal falta de realismo." (Bogdanov, 1984 [1908]: 76)

Como vimos, essa subsunção da arte em relação à vida enquanto ferramenta orientadora da ação política é característica da tradição rasnotchiets. A raiz desse criticismo é a Realnaia Kritika, desenvolvida por Belinski nos anos 1840, um método de interpretação que buscava tornar a linha existente entre a vida e a arte diáfana e extrair do texto o processo de criação artística a partir da análise concreta dos contextos históricos, sociais e psicológicos (Branco, 2008:344). A Realnaia Kritica será posteriormente radicalizada pelos críticos materialistas dos anos 1860, que extrapolam o realismo de Belinski para além da literatura, condicionando o realismo à própria ação política da Intelligentsia. A literatura é mimesis da vida, um reflexo pálido das forças sociais que atuam subjacentes ao processo criativo. Tchernichevski, em sua tese "o Belo é a vida" defendeu que "arte pela arte" produz meramente tipos universais a partir de homens reais, particulares, e por isso é sempre incompleta (Branco, 2008:344). O criticismo de Bogdánov é herdeiro do realismo crítico de Pissarev e Tchernichevki em sua integralidade. Bogdánov enxergava nesse hiato entre o universal artístico e o particular real as mesmas dicotomias presentes nas mais diversas esferas da experiência humana. Somente por meio da perfeita harmonia entre "forma" e "conteúdo" seria possível unificar a arte em um sistema monístico superior capaz de guiar o

10 Ver Capítulo 2, Seção 2.2.3. 
coletivo na criação de uma arte verdadeiramente proletária, fundamental para a constituição do empiriomonismo, i.e. a visão de mundo proletária.

Ainda em sua visita ao museu, Bogdánov aplicou sua teoria sociomórfica da história sobre o desenvolvimento da arte. A arte da antiguidade marciana, marcada pelo monismo primitivo, apresenta "uma tranquilidade majéstica, uma harmonia serena, uma ausência de tensão" (Bogdanov, 1984 [1908] : 76). Essa é a arte que corresponde à visão de mundo autoritária-religiosa, em que ainda não há a cisão entre as experiências individual e coletiva. Na fase intermediária, marcada pela visão-de-mundo burguesa, cuja experiência é cindida e fragmentada pelo fetichismo abstrato, elementos de outra ordem passam a transparecer nas obras: impulsos, paixões e forma eróticas que explodem sob a pressão produzida pela tensão entre as forças espirituais e corpóreas. Por fim a arte contemporânea, produzida a partir da visão de mundo empiriomonística, retorna aos elementos harmônicos primitivos em uma ordem organizacional mais elevada, cujos elementos denotam a unidade da experiência e da "racionalidade invencível" (Bogdanov, 1984 [1908] : 76). ${ }^{11}$

Leonid nos informa que metade do museu é dedicada à arquitetura. Nesse ponto o protagonista passa a descrever uma lista de obras, ferramentas e formas arquitetônicas desenvolvidas pelos marcianos no decorrer de sua história. Mais uma vez Bogdánov, a partir das reflexões de Leonid, tenta expôr a tensão existente entre as dimensões da experiência ao ressaltar que a arquitetura antiga marciana atingia a beleza somente às custas do conforto e durabilidade das obras. Leonid então questiona Enno, mãe de Netti e cicerone de Leonid durante sua estadia em Marte, sobre a natureza da arquitetura contemporânea e se essa permitia desvios da perfeição funcional em favor da beleza. Enno então responde: "Nunca. (...) Isso seria uma beleza falsa, artificialidade ao invés de arte" (Bogdanov, 1984 [1908] :77).

Leonid descobre que a produção artística marciana não se encontra exposta nos museus, mas nos espaços públicos, onde os marcianos “...decidem

\footnotetext{
${ }^{11}$ Uma das razões determinantes para a proscrição das contribuições de Bogdánov se deu pelo seu "mau" marxismo, i.e. o caráter anti-dialético de seu pensamento. Essa passagem, por outro lado, aponta para uma concepção dialética da história, em que a arte desalienada recupera em uma forma qualitativamente superior os elementos da arte primitiva, negando a sua negação, isto é, os elementos da arte burguesa. Deixemos essa nota como um apontamento para pesquisas futuras, que se debrucem sobre o papel da dialética em seu sistema organizacional.
} 
assuntos de interesse comum, estudam e pesquisam e usam seu tempo de lazer" (Bogdanov, 1984 [1908] :74). A arte é ubíqua, presente em todos os espaços de convivência, exceto nas fábricas e residências. Enno explica que isso se dá porque o maquinário tem uma beleza própria, admirada pela sociedade de trabalhadores marcianos; no caso das residências, porque as mesmas são tão somente espaços de repouso e que não compõem o espaço de sociabilidade. A arte torna-se indistinguível do trabalho e da ciência, tornando absurda sua propriedade individual enquanto peça. A obra de arte só é passível de apropriação individual quando se faz mercadoria - quando torna o valor não-quantificável de trabalho concreto em valor quantificável de troca. Tais conceitos são absurdos na sociedade marciana. O caráter pedagógico que Bogdánov dedica à arte e sua submissão à busca por formas organizacionais mais elevadas expressas nesse documento escrito em 1909 corrobora nossa hipótese inicial de que "Estrela Vermelha" expressa sua teoria em status nascendi, que se manifestará de forma madura em seus trabalhos posteriores.

Bogdánov reafirma o mundo urbano como espaço de convivência central no socialismo marciano, porém sua cidade não é a cidade capitalista. Sua fábrica não é a fábrica alimentada por carvão e vapor, mas a fábrica movida a energia elétrica. Seus trabalhadores não são reificados pelo trabalho alienado que visa tão somente à reprodução ampliada do Capital, mas:

"centenas de trabalhadores que se movem confiantemente entre as máquinas. (...) não há traço de ansiedade em seus rostos, cujas únicas expressões são de quieta concentração. Eles parecem inquisitivos, observadores eruditos que não interagem com tudo o que ocorre ao seu redor." (Bogdanov, 1984 [1908]:63)

Ao se dirigir para os trabalhadores russos, cuja força de trabalho lhes é expropriada e posta a serviço das máquinas, Bogdánov apresenta o trabalhador marciano, mestre da maquinofatura, que supervisiona a produção totalmente automatizada. Ao descrever uma fábrica impoluta - mais próxima de um laboratório do que de uma fábrica russa - Bogdánov aponta para as terríveis condições de trabalho do proletariado russo sujeitos à existência laboral mais insalubre (Fritzpatrick, 1994:19). Bogdánov cria a partir da descrição de funcionamento da fábrica marciana aquilo que Fredric Jameson 
classifica como "enclave utópico", i.e. a composição de um espaço imaginário dentro de um espaço social real. A partir desse enclave, a utopia marciana torna-se um reflexo negativo que permite aos trabalhadores enxergarem no possível, no extrapolado, as condições históricas objetivas em que se realiza o mundo para além das ilusões ideológicas que atenuam e ocultam as relações de exploração (Jameson, $2005: 15$ ).

A descrição do funcionamento da fábrica não pode ser desvinculado do espaço da cidade em "Estrela Vermelha". Como vimos anteriormente, a dicotomia cidade/campo carrega diversos sentidos e seu debate tem uma história própria, que atravessa momentos distintos: de um lado cidade/ocidente/indústria/capitalismo; do outro a obshchina/eslavofilia/agricultura/nativismo. A descrição de uma sociedade empiriomonística é o objetivo principal de Bogdánov. A partir do desenvolvimento da visão de mundo laboral, oriunda do domínio técnico da maquinofatura, a classe trabalhadora faz avançar a causalidade produtiva que torna irrelevante quaisquer dicotomias: mente e matéria, sujeito e objeto, cidade e campo, trabalho manual e trabalho intelectual. Assim como a energia na maquinofatura se converte livremente entre diversas formas (térmica, elétrica, mecânica, nuclear), também são cambiáveis todas as formas de labor. Ao desenvolver aspectos da produção marciana, Bogdánov tem como objetivo imagético delinear o funcionamento de uma sociedade que superou os limites estruturais impostos a si mesma pelo caráter fetichista da produção capitalista.

Para Bogdánov, cujas ideias se desenvolveram a partir da crítica à abordagem neokantiana de Berdiaev e ao materialismo ortodoxo de Plekhánov, o fio condutor que unificava a teoria marxista à práxis revolucionária era a teoria da alienação (Harvey, 2002:121). O caráter fetichista da produção capitalista não apenas fragmenta os saberes, a produção da vida material e separa os homens de si mesmo; ele também submete a consciência humana a todas as formas de dicotomia e escraviza o trabalho em favor de uma "necessidade abstrata" que passa a determinar, de forma extemporânea à vontade dos homens, sua relação com o mundo não como agente e sujeito, mas como objeto indispensável para a sua reprodução enquanto uma relação social autonomizada. Transcender o estado alienado do mundo, que se reflete 
em Bogdánov na experiência cindida entre o mundo objetivo-físico e o mundo subjetivo-psiquico é a tarefa que cabe à revolução. "Estrela Vermelha" é uma imagem bogdánoviana desse futuro. ${ }^{12}$

Bogdánov constrói por meio da narrativa ficcional suas respostas às questões colocadas por narodistas e marxistas, eslavófilos e ocidentalistas, urbanizadores e desurbanizadores. A partir de sua obra o autor justapõe às condições existentes de produção que lhe são contemporâneas extrapolações tecnológicas que objetivam produzir aquilo que Darko Suvin categorizou como Novum (conceito definidor) da FC: o estranhamento cognitivo, i.e. a extrapolação do real que permite ao leitor desanuviar as relações de opressão as quais se encontra submetido (Suvin, 1979 : ix).

A cidade marciana é o produto final do processo formativo de uma sociedade urbana a qual por sua vez é descrita por Henri Lefevbre como um processo de dominação imposto pela industrialização que absorve a produção agrícola. Lefevbre enxerga esse fenômeno por meio do avanço do processo de valorização do espaço que passa a organizar a produção e produzir descontinuidades no desenvolvimento histórico do espaço. Tais descontinuidades se acumulam até um determinado ponto crítico, quando então ocorre uma explosão que lança no espaço os diversos fragmentos que compõem a cidade. Essas descontinuidades representam o ímpeto totalizante

\footnotetext{
12 Não podemos dizer o mesmo, no entanto, sobre a própria obra de Marx. Exceto por alguns apontamentos na "Crítica ao Programa de Gotha", Marx sempre foi muito cauteloso em invocar o futuro, e se o fez nesse momento foi para realçar os erros teóricos de leitura de sua própria obra e que permeavam o programa de unificação dos partidos operários alemães (Marx, 2012). Essa cautela se justifica pelo próprio método marxiano, que pressupõe a compreensão da totalidade a partir do movimento dialético de suas especificidades, completamente inseridas nas determinações históricas e objetivas sobre as quais se debruça a análise dialética materialista. Terry Eagleton, ao discutir sobre a presença de elementos utópicos no pensamento de Marx, demonstrou ser essa uma resposta dotada de condicionalidades. De acordo com Eagleton, Marx era um utopista se entendermos utopia como um "vasto melhoramento do presente":
}

"Como um materialista, [Marx] estava alerta para a natureza complexa, recalcitrante e incompleta da realidade; e tal mundo é incompativel com uma visão de perfeição. Um mundo perfeito seria aquele que teria abolido todas as contingências, todas aquelas ocorrências de sorte, colisões aleatórias e efeitos tragicamente imprevisiveis que constituem a textura de nossas vidas diárias. (...) Tal sociedade não é possivel. E nem desejável." (Eagleton, 2011:55) 
do capital que metamorfoseia o espaço-obra em espaço-produto, que carrega a marca da mercadoria e transforma os espaços em valores de troca, cujos fins e usos são sempre historicamente determinados (Lefebvre, 2003).

O espaço marciano é citadino, industrial, porém a partir da definição de Lefebvre, não é urbano. Marte ultrapassou todas as fases críticas de seu desenvolvimento e a explosão de suas cidades não apenas causou danos irreparáveis ao ecossistema marciano como levou ao desaparecimento do campo enquanto espaço de reprodução social. A revolução marciana decorre desse fato. A cidade descrita por Bogdánov é consequência da superação dessas descontinuidades cuja última fase crítica resulta em uma explosão final que reconfigura o espaço e as experiências. Essa explosão lança a arte, a ciência e trabalho por todo o espaço. Já não mais a cidade é o espaço de reprodução do Capital, mas se torna o espaço de realização do ser genérico do homem: seu valor enquanto mercadoria desaparece e passa somente a existir enquanto espaço planejado, enquanto quartel na luta eterna entre as forças produtivas marcianas e a natureza. 


\section{4 \\ Entre o homem e a máquina: \\ Classes Sociais e Produção em \\ "Estrela Vermelha"}

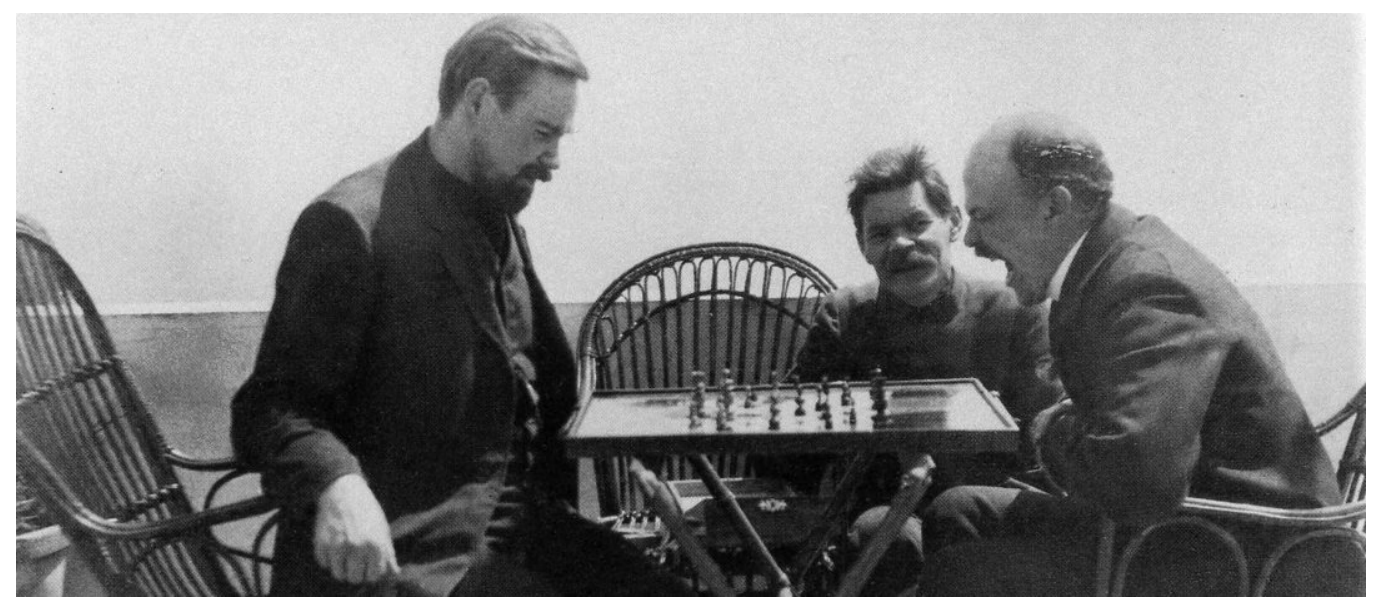

"Sangue vem sendo derramado em nome de um futuro melhor" respondeu Netti. "Mas a fim de travar tal luta, é necessário conhecer aquele futuro. E é em nome de tal conhecimento que você está aqui".

(Bogdanov, 1984 [1908] : 47) 
As razões que levaram ao rompimento definitivo entre Bogdánov e Lenin e ao cisma do centro bolchevique em 1909 são diversas e geraram divergências entre os estudiosos que se debruçaram sobre essa questão. Autores como Jensen (1978:3) e Sochor (1988:7) apontam para a controvérsia referente aos fundos ilegais da facção bolchevique, então administrados por Leonid Krasin e Aleksandr Bogdánov cujas formas de aquisição eram vistas com desconforto por Lenin, principalmente depois que o POSDR elegeu deputados para a III Duma; Daniels (1960:21) e Biggart (1990:5) se concentram nas diferenças táticas e programáticas que separavam os dois líderes bolcheviques no contexto pós revolucionário de 1907: enquanto Lenin enxergava na participação dos Deputados eleitos para a III Duma um palco de agitação política e uma nova frente de ação para desgastar poder da Autocracia Russa, Bogdánov defendia o aprofundamento das atividades de propaganda, acreditando ainda na retomada do fervor revolucionário de 1905 e exigindo por meio de um ultimato o compromisso dos deputados eleitos para com a radicalização. Rowley (1996:6) defende a centralidade do debate acerca do papel espontaneísta das massas como determinante para a ruptura entre os dois líderes.

Dentre essas diversas interpretações, Marot (1990:246) apresenta aquela que tomamos como a mais sofisticada: o cisma de 1909 acabou catalisado por profundas diferenças filosóficas acerca dos fundamentos do marxismo. Essa havia sido uma ruptura epistemológica que se manifestou nas questões programáticas, táticas e políticas que alimentaram os debates da época e marcou definitivamente as carreiras revolucionárias e os fundamentos teóricos de ambos. Para Bogdánov, o cisma de 1909 e sua expulsão da facção bolchevique o levou à criação do círculo vperedista, que atuou na Itália entre 1909 e 1911. Após sua dissolução, Bogdánov se afastou progressivamente das atividades políticas em favor de estudos filosóficos, culturais e posteriormente científicos (Rowley, 1996 : 11). Lenin, por sua vez, produziu sua principal obra filosófica: "Materialismo e empiriocriticismo" e se tornou líder inconteste da facção bolchevique, estabelecendo ali as bases epistemológicas do que viria a ser tornar marxismo-leninismo.

Alguns cuidados precisam ser tomados ao analisar historicamente este debate. O posicionamento de estudiosos raramente apresenta qualquer tentativa 
de se afastar desse objeto. Por um lado é aparente que as tentativas em reabilitar a obra de Bogdánov aparecem carregadas de um profundo antileninismo (em alguns casos, como Richard Pipes, de aberto e declarado anticomunismo). Mesmo abordagens realizadas pela Escola Revisionista carregam a pena de excessivo criticismo quando tratam da controvérsia entre Lenin e Bogdánov. Zenovia Sochor afirma que a obra "Materialismo e Empiriocriticismo" é mais reconhecida por seu conteúdo político que filosófico, por entender que a mesma foi escrita especificamente para minar a representatividade de Bogdánov junto à Intelligentsia (Sochor, 1988:7); J.K. Jensen relacionou de forma pouco sofisticada - para dizer o mínimo - o conteúdo de "Materialismo e Empiriocriticismo" com os fundamentos do stalinismo pós anos 30, em um claro acinte metodológico (Jensen, 1978:4); James White defende que Lenin, ao escrever "Materialismo e Empiriocriticismo", tinha em mente dois únicos objetivos: defender Plekhánov e atacar Bogdánov (White, 2018:238).

Em sentido contrário, as críticas que se fazem à obra de Bogdánov partem quase que exclusivamente da leitura de "Materialismo e Empiriocriticismo", reproduzindo ad nauseam os argumentos utilizados por Lenin para desconstruir o "machianismo" de Bogdánov, sejam esses fundados ou não. Sternin, sobre o contexto histórico de produção da obra, afirma que Lenin a escreveu de forma a dar combate à ala bolchevique que tentava unir "a filosofia marxista ao machianismo, variante confusa do idealismo subjetivo, ou pelo menos "substituir" a doutrina filosófica de Marx e Engels por conceitos de Mach" (Sternin, 1988:9). Elyenkov ressalta que "Materialismo e Empiriocriticismo" colocou um fim "em uma filosofia reacionária e suas pretensões ao papel de "filosofia das ciências naturais contemporâneas" (Ilyenkov, 2009 : 286). Exemplos se propagam em ambas as direções, fato que por si mostra a importância do debate epistemológico empreendido pelos dois líderes bolcheviques.

Acreditamos que seria interessante prover um cotejamento entre " $\mathrm{Ma}$ terialismo e Empiriocriticismo" e "Ensaios sobre Empiriomonismo". Esse seria um trabalho que lançaria luzes sobre aspectos pouco analisados de ambas as obras, vistas sob o prisma de sua contraparte. No entanto, dado o escopo desse trabalho, não o faremos aqui de forma sistemática. Através das críticas de Lenin expressas em sua obra buscaremos atingir dois objetivos, a 
saber: propor para além da questão epistemológica a hipótese que qualifica tal debate em um nível mais profundo, essencialmente organizacional; a partir dessa dimensão, refletir sobre as formas que Bogdánov emprega em "Estrela Vermelha" para tratar das questões referentes ao poder, à produção e às classes sociais, articulando-as tanto com seu pensamento quanto com as respostas encontradas pelo nascente Estado soviético frente às condições concretas herdadas pelo contexto histórico russo.

\subsection{Materialismo dialético como epistemologia da ciência}

A historiografia tradicional em geral - e marxista em particular - compartilha das visões de Lenin sobre as consequências imediatas da derrocada da Revolução de 1905 (Hobsbawm 1988: 398; Sternin 1988:8). A ressaca do movimento despertou na Intelligentsia russa as mais diversas reações, desde o afastamento da luta revolucionária, como é o caso do círculo de marxistas legalistas de Berdiaev, até a proliferação de diversas correntes revisionistas e místicas que buscavam explicar as razões do fracasso e a posterior reação do regime czarista. Dentre a miríade de interpretações da obra marxiana produzidas por um universo intelectual extremamente diverso, Lenin escolheu a influência machiana como principal risco para a unidade da facção bolchevique. Essa escolha não se deu de forma arbitrária. Bogdánov, ao lado de intelectuais como Lunacharski e Bazarov, buscou de fato atualizar a teoria marxista a partir do empiriocriticismo de Ernst Mach e Richard Avenarius, uma vez que entendia haver "lacunas" na obra de Marx quanto ao papel do conhecimento e das ideologias na capacidade de resiliência da forma capitalista de produção (Sochor, 1988:7). Para além da questão epistemológica, pesava também na decisão de Lenin o papel protagonista que Bogdánov exercia junto aos radicais e intelectuais do bolchevismo. O papel de liderança de Bogdánov naqueles anos talvez explique por que Lenin ignorou diversas outras derivações para centrar suas baterias contra o machianismo. Para entendermos a crítica de Lenin ao empiriomonismo de Bogdánov, talvez seja necessário compreender 
contextualmente como ambos desenvolveram sua teorias a partir desse debate.

Anton Pannekoek descreve o marxismo russo como resultado das particularidades concretas de formação do capitalismo russo e de que forma tais particularidades separaram tanto as interpretações da obra marxiana entre russos e marxistas ocidentais, quanto as formas de organização das lutas revolucionárias (Pannekoek, 2003 : 150). Para Pannekoek:

“...marxismo na Rússia, desenvolvido como a teoria daqueles engajados no conflito social, assumiu naturalmente outro caráter daquele que assumiu na Europa Ocidental. Ainda era a teoria de uma classe trabalhadora combativa, mas essa classe devia lutar primeiro e acima de tudo por aquilo que na Europa Ocidental havia sido a função e trabalho da burguesia, com os intelectuais como seus associados." (Pannekoek, 2003:148)

Para além do atraso econômico e do peso da autocracia, Pannekoek parece ignorar a longa tradição radical russa. As condições que ele entende como formadoras do marxismo russo antecedem em muito a própria tradição marxista russa. Essas condições então no processo formativo da Intelligentsia, uma categoria social particular do contexto russo. A Intelligentsia não é resultado do desenvolvimento da teoria marxista diante da condição local; ela é, como as condições locais, elemento fundante da particularidade da teoria marxista russa. Os debates entre os diversos grupos pertencentes à Intelligentsia são fundamentais para compreender seu desenvolvimento e se estendem desde o começo do século XIX com o movimento dezembrista. Vimos no capítulo anterior como Lenin desenvolve sua teoria revolucionária a partir de um amplo debate contra os narodistas e incorpora em sua teoria elementos do pensamento radical russo (Krausz, 2015 : 111). Também vimos no primeiro capítulo que o mesmo se deu com Bogdánov em outro contexto e se desenvolveu a partir do debate com Nicolai Berdiaev acerca da moralidade revolucionária.

Feita essa observação, torna-se difícil, ao ler "Materialismo e Empiriocriticismo", discordar de Pannekoek sobre a natureza da obra: "um panfleto de guerra escrito por um lider que buscava afastar por quaisquer meios necessários o perigo que rondava seu partido" (Pannekoek, 2003:153). Essa 
afirmação, ainda que parcialmente correta, não é justa pela simplificação que faz de "Materialismo e Empiriocriticismo". A obra de Lenin não pode, a despeito da ferocidade de sua forma, ser considerada um panfleto. Se é verdade que Lenin a utiliza como arma para combater o revisionismo de Bogdánov, também é verdade que "Materialismo e Empiriocriticismo" serviu de fundação filosófica para o marxismo-leninismo e reverberou nas décadas seguintes como obra referencial categórica sobre o materialismo histórico (Sternin, 1988:72). Além disso, Pannekoek concorda que "Lenin estava inteiramente correto em sua ação" (Pannekoek, 2003 : 153). A crítica central de Pannekoek se baseia naquilo que ele considera uma falsificação do objeto que Lenin critica: o fundamento da filosofia de Ernst Mach.

De acordo com Jensen (1978:12), o termo "machianismo" foi utilizado pela primeira vez por Plekhánov em 1905 durante o $4^{\circ}$ Congresso do POSDR para designar o grupo de social-democratas que dera embate aos marxistas neokantianos e acabaram influenciados pelo empiriocriticismo. A partir do cisma de 1909, o termo "machiano" passou a ser utilizado como forma derrogatória para designar quaisquer marxistas que tentassem interpretar a obra marxiana de forma heterodoxa, em desacordo com a "Partinost".

Excetuando toda uma gama de marxistas heterodoxos que foram em um momento ou outro rotulados como "machianos", esse é um termo que cabe somente a um número reduzido de intelectuais: Valentinov, Berman, Jushkevich, Bazarov, Gelfond, Surorov e Bogdánov. E entre esses somente Bogdánov legou um volume expressivo de textos. A maior parte dos colaboradores de Bogdánov nesse período acabaram, em um momento ou outro, aderindo à concepção ortodoxa de Plekhánov e Lenin (Jensen, 1978: 14).

Como vimos anteriormente, Bogdánov se utilizou do conceito monístico de experiência de Ernst Mach para refutar as categorias apriorísticas de Berdiaev. No entanto, ao propor a suspensão, a partir da categoria empiriocriticista de experiência, da dicotomia entre matéria e espírito, Bogdánov acabou em rota de colisão com Plekhánov. Essa divergência se estendia desde 1899, quando Akselrod publicou uma crítica bastante hostil ao primeiro trabalho filosófico de Bogdánov: "Elementos Básicos da Visão Histórica da Natureza". Nessa obra, escrita a partir dos cursos que ministrava nos círculos operários de 
Tula, Bogdánov fez suas primeiras incursões nos conceitos que formariam posteriormente a estrutura de sua filosofia. Na busca por um sistema lógico que desse conta de questões filosóficas cada vez mais amplas e que adequasse a filosofia marxista às descobertas das ciências naturais, Bogdánov acabou por rejeitar a dialética por entender que essa não era capaz de dar conta da multiplicidade de processos que ocorrem na natureza. A dialética, segundo ele:

“...sugere fatos de desenvolvimento que são característicos de seres vivos... (...) indica precisamente o desenvolvimento por contradição', o que é menos ainda um fato universal." (White, 2018:21)

A partir da constatação de que todo sistema encontra-se em constante estado de fluxo energético com seu ambiente, Bogdánov propôs que a organização de um sistema era determinada pela relação entre forças componentes dentro desse mesmo sistema, cuja resultante tendia a se anular. Em lugar da dialética Bogdánov propôs uma teoria dinâmica do equilíbrio, cuja manifestação poderia ser observada em todas as esferas da existência. Para Bogdánov, sua teoria dinâmica do equilíbrio poderia explicar mais sucintamente e com maior nível de precisão a passagem entre as transformações quantitativas para qualitativas, i.e. o objeto dialético da crise. Uma crise nada mais seria do que a superação de uma força sobre outras forças contra-arrestantes (White, 2018:33). Esse processo de constante adaptação entre os elementos encontram-se no cerne do empiriocriticismo de Mach, fortemente influenciado pela teoria da seleção natural de Darwin e pelo energitismo de Ostwald (White, 2018:40). Não cabe nesse momento fazer uma descrição pormenorizada da filosofia machiana. No entanto descreveremos brevemente alguns aspectos do pensamento de Mach, de forma a contextualizar a crítica de Lenin e Plekhánov ao "machianismo" russo de forma geral e ao pensamento de Bogdánov de forma particular.

Para Mach, toda percepção é resultado de uma relação adaptativa entre o pensamento e o ambiente. É por meio da percepção que organismos adquirem dados do ambiente e a partir desses dados avançam em direção a uma posição de equilíbrio entre si e os estímulos ambientais. Esse equilíbrio 
encontra-se sempre localizado em uma limite ótimo de dispêndio de energia em relação ao processo de adaptação: quanto mais energia é economizada no processo de adaptação, mais eficiente são complexos de elementos que organizam esse processo. A conservação de energia era para Mach o critério de verdade objetiva: é por meio do "output" de esforço despendido para obter equilíbrio que se estabelece uma forma ótima e, portanto, verdadeira (Banks, 2003 : 35). Para Mach, toda e qualquer análise de cunho científico deveria partir desses complexos de sensações, empiricamente mensuráveis por meio da observação. Sua posição epistemológica lhe colocava em confronto direto com a abordagem mecanicista da ciência do final do século XIX ao rejeitar quaisquer abstrações que busquem explicar o fenômeno sem que possam ser empiricamente verificadas e descritas. Era a partir desse pressuposto que Mach rejeitava o atomismo e a concepção newtoniana de espaço, por considerar que ambas pressupunham um elemento absoluto - seja da matéria, seja do espaço. ${ }^{1}$

A natureza, que contém os elementos em estado de caos, interage por meio das sensações com a consciência, que produz, a partir da interconexão com esses elementos neutros, complexos de elementos, passíveis de ser reduzidos às particularidades fundamentais da experiência e, a partir daí, incorporados à experiência e finalmente descritos. Toda metafísica é descartada em favor da descrição dos fenômenos uma vez que as "coisas-em-si" são irrelevantes, já que não podem ser experimentadas e testadas. O monismo neutro de Mach era essencialmente fenomenológico (Banks, 2003 : 105).

Bogdánov partiu do monismo neutro de Mach para fundamentar sua abordagem fenomenológica do marxismo e, por conta disso, travou um longo debate com Plekhánov. Esse enxergou na teoria de Mach um violento desvio do materialismo, pedra fundamental da filosofia marxista, cujos fundamentos ameaçavam contaminar a social-democracia russa com idealismos e solipsismo.

Entre os dois teóricos encontrava-se Lenin. Filiado filosoficamente à corrente ortodoxa de Plekhánov, Lenin encontrou-se apartado de seu mentor

\footnotetext{
1 De acordo com Eric Banks, Mach rejeitava a ideia newtoniana de espaço e tempo absolutos, pois acreditava que uma posição dada em um eixo tridimensional é sempre relativa a um determinado ponto de origem. Para Mach toda posição é relativa à posição de um observador. Eric Banks credita à crítica de Mach dirigida à mecânica newtoniana alguns elementos que antecipam a mecânica relativista de Albert Einstein (Banks, $2003: 22$ ).
} 
a partir de 1904, quando Plekhánov passou a apoiar a facção menchevique; ao mesmo tempo, Bogdánov, abertamente revisionista, trouxe para facção bolchevique importantes intelectuais como Lunacharsky e Stepanov. Preso entre conviç̧ão filosófica e necessidade política, Lenin concordou em manter a facção filosoficamente neutra, evitando assim um debate direto com Bogdánov e seus companheiros. Plekhánov e Akselrod não perdiam uma oportunidade de lembrá-lo de sua posição delicada. No $3^{\circ}$ Congresso do POSDR, realizado em maio de 1905, Plekhánov acusou diretamente a facção bolchevique de flertar com com o revisionismo filosófico de Ernst Mach. Esse embaraço era agravado pelo fato de que o principal veículo bolchevique - o jornal "Proletários" - tinha entre seus editores três intelectuais revisionistas: Bogdánov, Lunacharsky e Bazarov (Joravsky, 1961 : 28).

Entre os anos de 1905 e 1908, o debate acerca da ortodoxia foi empreendido por Bogdánov e Plekhánov. Em 1907, em artigo intitulado "Carta aberta para Plekhánov" (Otkrytoe pis'mo Plekhánovu) e publicado no jornal Arauto da Vida, Bogdánov exortou Plekhánov a publicar integralmente suas análises sobre o machianismo e revisionismo bolchevique (Joravsky, 1961 :31). Essa resposta só viria a ser publicana no ano seguinte, em setembro de 1908, no jornal "Voz Social-Democrata" (Golos Sotsial-demokrata) com o título "Materialismus Millitans: Réplica para o Sr. Bogdánov". Nessa carta aberta Plekhánov reafirma toda sua hostilidade em relação à pessoa de Bogdánov (o senhor não é meu camarada) e pontua suas principais críticas ao empiriocriticismo (Plekhanov, 1976 [1908]), críticas essas que seriam posteriormente retomadas por Lenin em "Materialismo e Empiriocriticismo".

Em sua reposta, Plekhánov reafirma sua posição em favor da definição kantiana de matéria: "matéria é nada mais do que a totalidade de coisasem-si; tais coisas constituem a fonte de nossas sensações". No entanto, Plekhánov aponta que as categorias apriorísticas de Kant acabavam por se contradizer em relação à materialidade das coisas-em-si e por essa razão seus seguidores neokantianos acabavam obrigados a escolher entre o idealismo subjetivo e o materialismo. De acordo com o autor, esse dilema é superado por Feuerbach: "ao provar que algo é, significa que aquele algo existe não apenas em pensamento"; e Engels: "A real unidade do mundo reside em sua 
materialidade" (Plekhanov, 1976 [1908]).

A partir desses dois postulados, Plekhánov define aquilo que entende por objetos materiais:

"Nós chamamos objetos materiais aqueles objetos que existem independentemente de nossa consciência e, agindo sobre nossos sentidos, excitam em nós certas sensações, as quais por sua vez delineiam nossas noções do mundo externo, isto é, daqueles mesmos objetos materiais, bem como de suas relações." (Plekhanov, 1976 [1908])

A seguir Plekhánov cita Mach a partir de sua obra "Análise das sensações", inserindo na citação suas próprias interpretações:

"Não são corpos que produzem sensações, mas complexos de elementos (complexos de sensações) que formam corpos. Se corpos parecem a um físico ser algo duradouro e real e elementos sua reflexão transiente e transitória, ele não percebe que todos os corpos são tão somente símbolos lógicos para complexos de elementos (complexos de sensação)." (Plekhanov 1976 [1908]. Grifo acrescido.)

Uma leitura da obra de Mach nos mostra que em sua filosofia "complexos de elementos" não é o mesmo que "complexo de sensações", como Plekhánov sugere. As sensações são, para Mach, o fenômeno constituinte da intersecção de elementos físicos-neutros e psíquicos-cognitivos. A sensação não é sinônimo, mas deriva do complexo de elementos que surgem por meio da experiência. A cognição atribui significados aos dados que partem dos elementos neutros e que são apreendidos na forma cognitiva de objetos. O complexo de elementos de Mach também é composto por elementos de volição (tempo, espaço, temperatura) que não estão vinculados diretamente à condição do corpo (elemento físico) ou da cognição (elemento psíquico), mas de condições fugidias que carregam os signos de qualidades relacionais e permitem que a experiência adquira sentido de movimento (Boll, 1981:42).

Por meio de sua definição de matéria como "objeto que existe independentemente da consciência", Plekhánov define por sua vez o que entende por experiência:

"Cada experimento e cada atividade produtiva do homem representa uma relação ativa de sua parte com o mundo externo, uma invocação 
deliberada de determinado fenômeno. E como um fenômeno é fruto da ação de uma coisa-em-si sobre mim (Kant diz a afetação de mim por aquela coisa), ao executar um experimento ou engajar na produção desse ou daquele produto, eu forço a coisa-em-si a "afetar" meu ego em uma maneira definida, determinada por mim de antemão." (Plekhanov, 1976 [1908])

Para Plekhánov, a experiência consiste na ação do sujeito sobre um objeto que existe fora dele mesmo, que lhe é exterior. Para ele, objetos continuam a existir em sua materialidade, independentemente se os mesmos encontramse ou não ao alcance da experiência. Em um segundo momento da carta, Plekhánov volta a vincular a existência da materialidade como fato anterior à experiência:

"Ao dizer "nossa experiência", eu tenho em mente experiência humana. Mas estamos cientes que houve um tempo em que não havia humanos em nosso planeta. E se não havia humanos, tampouco havia experiência. No entanto a Terra ainda existia. E isto significa que isso (também uma coisa-em-si) existia fora da experiência humana." (Plekhanov, 1976 [1908])

Parece-nos aparente que essa crítica é menos um ataque às concepções empiriocriticistas de Mach e mais uma reafirmação da definição ortodoxa de matéria, razão que principiou em primeiro lugar o debate entre machianos e neokantianos no começo do século XX. Nem Mach e tampouco Bogdánov afirmaram que a natureza existe tão somente a partir da experiência humana, como faz supor o exemplo de Plekhánov. Para ambos, a natureza existe externamente, mas em uma forma neutra - em estado de caos - e é reorganizada pela cognição por meio da experiência. Também para ambos os estímulos que nutriam a experiência ingressavam do mundo exterior, na forma de elementos físicos. A acusação de idealismo, ainda que verdadeira, parte de uma premissa falsa: a concepção de supremacia do psíquico sobre o físico. Essa premissa entra em desacordo com o monismo de ambos os pensadores, que viam o mundo natural como uma realidade holística, da qual a cognição era parte integrada (Bogdanov, 2016 [1913]: xvi).

A estrutura formal das cartas "Materialismus millitans" de Plekhánov nos fornece possibilidades de análise inéditas quanto ao debate entre materialistas 
e machianos. Há uma história desse debate oculta em meio às críticas e acusações e que fornecem evidências palpáveis para a hipótese apresentada no começo desse capítulo: a diferença que apartou os dois líderes revolucionários, Lenin e Bogdánov, no cisma de 1909 é fundamentalmente organizacional.

Plekhánov estruturou sua crítica escolhendo como alvo principal de sua análise o empiriocriticismo de Mach cuja influência entre a Intelligentsia fomentou, de acordo com ele, um idealismo subjetivo e essencialmente solipsista. É interessante notar que Plekhánov não dedica em seu trabalho grande esforço para analisar o pensamento de Bogdánov como um trabalho independente. Para Plekhánov bastaria desconstruir o falso monismo de Mach para lançar por terra as teorias de Bogdánov. Esse é tratado por Plekhánov com indisfarçado desprezo, como alguém que "não sabe nada sobre materialismo, seja sobre sua história, seja como é hoje"; ou "(...) como um homem de considerável diligência, mas de muito pouco talento" (Plekhanov, 1976 [1908]). Plekhánov, para derrubar Bogdánov, mirou em Mach. Essa estratégia discursiva é reproduzida por Lenin em "Materialismo e Empiriocriticismo". Ainda que seja uma obra mais sofisticada e de maior fôlego do que os artigos de Plekhánov, Lenin se utiliza da mesma estratégia: centrar suas críticas no empiriocriticismo de Mach, desviando-se da tarefa de aprofundar suas críticas à obra autoral de Bogdánov, reservando-lhe três breves seções de sua obra.

As semelhanças entre as estratégias discursivas adotadas por Lenin e Plekhánov levantam hipóteses interessantes que lançam nova luz sobre o cisma bolchevique de 1909 e que não foram previamente levantadas na bibliografia que se debruça sobre a questão. Muitos estudiosos já citados apontam para a publicação de "Materialismo e Empiriocriticismo" como marco final da trégua filosófica estabelecida entre Lenin e Bogdánov quando do ingresso desse último às fileiras bolcheviques em 1904. Joravsky (1961) argumenta que Lenin lutou até o último momento para conservar a neutralidade da facção em assuntos de filosofia em favor da unidade política, resistindo a todas as provocações lançadas contra ele por Plekhanov e Akselrod e, mesmo durante o episódio da III Duma em 1907 que colocou Lenin e Bogdánov pela primeira vez em campos opostos no que se referia à unidade política. Às vésperas 
da ruptura, Lenin insistiu em manter o partido neutro quanto às questões filosóficas, desejo que expressou em diversos momentos, como em sua visita à villa de Gorky em Capri no verão de 1908, onde Bogdánov residia em exílio (Jensen 1978:22, Sochor 1988: 43, Joravsky 1961:34).

Joravsky enxerga na publicação de "Materialismo e Empiriocriticismo" menos um ataque político a Bogdánov e mais uma reafirmação da unidade do POSDR. De acordo com o autor havia um esforço da facção menchevique em acusar Lenin e sua facção de abraçar em sua totalidade o revisionismo machiano. Deborin, um jovem discípulo de Plekhánov, chegou a publicar em um veículo menchevique - o periódico "Voz Social-Democrata" -, em abril de 1908, que “... [a] Marca do subjetivismo e voluntarismo repousa em todas as táticas do assim chamado bolchevismo, cuja expressão filosófica é o machianismo. (...) os táticos e práticos bolcheviques são machianistas e idealistas inconscientes" (Joravsky, 1961:34). Lenin objetivava a partir da publicação dessa obra retirar dos mencheviques a primazia sobre a ortodoxia filosófica - uma vez que havia machianos nas fileiras de ambas as facções - restando a esses o espaço do debate político. Em carta a Gorky, Lenin justificou que com essa publicação os "...mencheviques se reduzirão à política, e isso é a morte para eles" (Joravsky, 1961 : 35).

Podemos questionar se, dada a semelhança de forma entre os dois documentos e o curto intervalo que os separam, é possível inferir a possibilidade de uma atuação conjunta entre Lenin e Plekhánov visando ao objetivo de romper com a trégua de 1904 e dar combate ao revisionismo machiano. No entanto, não há documentos que suportem essa afirmação. Ao mesmo tempo em que atacou as posições machianas e realizou uma elaborada defesa da ortodoxia de Plekhánov, Lenin não perdeu de vista que Plekhánov era um opositor nas posições políticas. Ele ressalta que o mesmo se preocupou menos em refutar Mach e mais em provocar um dano fracionário ao bolchevismo (Lenin, $1982 a: 268$ ).

Essa colocação, ainda que apresentada em uma nota de rodapé, encontrase de acordo com as intenções de Lenin expressas em missiva para Gorki. Ao unificar a posição do partido filosoficamente, Lenin acabaria por retirar a força que Plekhánov, enquanto importante teórico marxista, emprestava aos 
mencheviques, restando para esses tão somente o campo político. Bogdánov e os bolcheviques machianos acabaram por oferecer o álibi perfeito para que Lenin encerrasse seu silêncio no campo da filosofia.

Não podemos reduzir "Materialismo e Empiriocriticismo", como fez Pannekoek, a mero panfleto de guerra. Como pudemos ver, existe no contexto de sua produção um intrincado debate suprafaccional que envolveu os principais intelectuais marxistas russos daquela época com importantes consequências políticas e a publicação de "Materialismo e Empiriocriticismo" - mais um testemunho da genialidade política de Lenin - exerceu ali importante papel. Os historiadores que se debruçam sobre esse período tendem, talvez por influência do pragmatismo que se associa comumente à imagem de Lenin, a reduzir "Materialismo e Empiriocriticismo" a condição de "arma", a qual Lenin utilizou para estabelecer a Partinost e derrotar seus oponentes dentro da facção bolchevique. Essa abordagem acaba por limitar a obra de Lenin a um epifenômeno da disputa política que fazia parte do contexto daquele debate (Marot, 1993:147). No entanto, sabemos que Lenin, mesmo depois de sua publicação, insistiu na neutralidade dentro do partido nas questões filosóficas e afirmou várias vezes que seu objetivo era afastar qualquer interpretação do materialismo dialético que direcionasse o partido em direção ao fideísmo. Para Lenin, o que veio a ser debatido naqueles anos não era filosofia, mas religião (Joravsky, 1961:40). Em favor de Lenin, apresenta-se o fato de ele recebeu de volta, já em 1912, diversos membros do grupo vperedista nas fileiras do partido com a única condição de que não se utilizassem dos periódicos oficiais para expôr questões filosóficas (Joravsky, 1961: 43).

Ao se lançar no debate acerca dos fundamentos filosóficos do conhecimento científico, Lenin estabeleceu as bases epistemológicas daquilo que viria a se tornar sua concepção de hegemonia, bem como os alicerces organizacionais do Estado socialista. Ao defender Plekhánov e sua concepção de matéria, Lenin objetivou provar que o materialismo de forma geral contém em si os elementos necessários para fundamentar filosoficamente o conhecimento científico (Marot, 1993: 152). Não faremos aqui uma resenha pormenorizada de "Materialismo e empiriocriticismo". Interessa-nos, a partir de sua leitura, reproduzir sucintamente alguns de seus principais aspectos de forma a 
compreender o desenvolvimento do pensamento de Lenin.

Tomaremos como ponto de partida a forma como Lenin define "matéria" por entendermos que há semelhanças no método de exposição de Lenin com aquele utilizado por Marx em "O Capital", i.e. partir da categoria elementar e específica (mercadoria) para a totalidade das formas universais (Capital) e suas inter-relações. A definição de matéria em "Materialismo e Empiriocriticismo" percorre toda a obra, tornando-se mais sofisticada e plástica à medida que Lenin avança em seu argumento central: a defesa do materialismo como fundamento autossuficiente da ciência. Após elaborar longa crítica às inadequações das teorias de Avenarius e Mach sobre o caráter sensual da matéria, Lenin define a matéria como uma “(...) categoria filosófica para designar a realidade objetiva, que é dada ao homem nas suas sensações, que é copiada, fotografada, refletida pelas nossas sensações, existindo independentemente delas." (Lenin, $1982 a$ :97). Posteriormente ao procurar uma definição científica para o conceito, Lenin reforça essa descrição: "a realidade objetiva que existe independentemente da consciência humana e que é refletida por ela" (Lenin, $1982 a$ : 198). Por fim Lenin sustenta a categoria do movimento - fundamental para o processo dialético de desenvolvimento - como realização da concretude do mundo que se reflete no pensamento. Não pode haver matéria sem movimento: "O mundo é o movimento dessa realidade objetiva, refletida pela nossa consciência" (Lenin, 1982a:203).

A crítica de Lenin à concepção de matéria de Avenarius e Mach concentrase no fato de que suas concepções negam a matéria que existe independentemente da consciência e tornam o critério de objetividade um fator mediador entre o físico e psíquico, produzindo aí um relativismo subjetivista em que tal critério é determinado pela experiência do sujeito. Para Lenin a matéria é coisa-em-si e tem uma objetividade absoluta, cuja existência não pode ser relativizada sem adentrar em quaisquer das muitas formas de materialismo. No entanto, diferentemente da teoria dos hieróglifos de Plekhánov, essas representações da matéria diferem na consciência de sua fonte precisamente porque a fonte encontra-se sempre em movimento em relação à consciência (Lenin, 1893 : 180).

Marot (1993) aponta que, ao estabelecer esses três postulados i.e. 1) 
a natureza objetiva da matéria; 2) a reflexão dos fenômenos que partem da matéria na consciência; e 3) a natureza da matéria encontra-se em constante movimento, Lenin ancorou as bases do pensamento científico em uma epistemologia materialista. A matéria existe sob uma condição absoluta e, se assim o é, também há uma verdade última. Ao negar a natureza objetiva da matéria, machianos acabam por confundir critérios de verdade e objetividade da verdade, produzindo por isso uma teoria anticientífica, porque antimaterialista. Para Lenin, os machianos - e Bogdánov acabam por confundir critério de verdade com objetividade da verdade. A verdade última não perde sua existência objetiva tão somente pelo fato de que a fronteira que separa o conhecimento da verdade é imanente, móvel e historicamente determinada. Lenin demonstra que, ao negar a natureza independente da matéria em relação às nossas percepções e sujeitar a matéria enquanto elemento da experiência que se encontra em relação com quaisquer outros elementos, sejam físicos ou psíquicos, os empiristas acabam por negar qualquer verdade objetiva:

"A inconsequência do vosso empirismo, da vossa filosofia da experiência, consiste nesse caso em que negais o conteúdo objectivo na experiência, a verdade objectiva no conhecimento experimental." (Lenin, $1982 a: 96)$

Para Lenin tantos machianos - Bogdánov em particular - quanto materialistas metafísicos falham em distinguir a verdade absoluta contida no mundo físico e as verdades relativas determinadas por critérios de verdade móveis, cujas fronteiras avançam conforme se expande o próprio conhecimento acerca do objeto. Isso se dá porque, de acordo com Lenin, ambos não percebem a relação dialética que se dá entre as verdades relativa e absoluta (Lenin, $1982 a$ : 100). Para afirmar sua posição, Lenin cita Engels em "Anti-Duhring":

"o pensamento humano é tão soberano como não soberano, e a sua capacidade de conhecimento é tão ilimitada como limitada. Soberano e ilimitado pela sua natureza (ou estrutura), vocação, possibilidade e objectivo histórico final; não soberano e limitado pela sua realização individual e pela realidade dada num ou noutro momento." (Lenin, $1982 a: 101)$ 
A partir de Engels, Lenin define um movimento dialético em direção à verdade absoluta - soberana e ilimitada - a partir da soma de verdades relativas - limitadas e historicamente determinadas. O critério de verdade corresponde à aproximação a partir de verdades relativas da verdade soberana. Essas verdades relativas são "grãos" de verdades absolutas tão somente em limites muito estreitos (Yassour, 1983:25). As leis científicas são uma verdade apenas aproximadamente, quando expostas em limites determinados. Conforme avançam esses limites a partir do crescimento do conhecimento um movimento dialético que opera a partir da antinomia entre o erro e a verdade - novas verdades relativas se somam e antigas verdades acabam com limites mais estreitos ou mesmo descartadas em um processo crescente em direção à verdade soberana (Lenin, $1982 a: 102)$. De acordo com Lenin:

"Do ponto de vista do materialismo contemporâneo, isto é, do mar-
xismo, são historicamente condicionais os limites da aproximação dos
nossos conhecimentos em relação à verdade objectiva, absoluta, mas é
incondicional a existência dessa verdade, é incondicional que nós nos
aproximamos dela." (Lenin, $1982 a: 102)$

Esse é o fundamento materialista-dialético da teoria do conhecimento que Lenin defende em "Materialismo e Empiriocriticismo". É a partir da soma de verdades relativas que o conhecimento se move em direção à verdade objetiva, passível de ser apreendida na sua totalidade delimitada sistemicamente. A impressão que os fenômenos do mundo exterior produzem na consciência encontram-se interconectados e é a partir do acúmulo desses reflexos que se constrói uma visão cada vez mais ampla e precisa desse mesmo mundo.

Fica ainda mais claro a partir desse ponto que a bibliografia que versa sobre esse debate encontra dificuldades em produzir análises que não sejam enviesadas. Marot aponta como causa para esse problema uma longa tradição de comentadores ocidentais que se especializaram naquilo que ele denomina como "Lenin-Bashing tradition", decorrente da associação direta entre a teoria leninista e o regime soviético pós-1928 (Marot, 1993:162). Essa mesma tradição, responsável em grande parte pela recuperação da obra de Bogdánov, acaba por esse mesmo motivo impedindo que sua obra seja lida a partir de seus próprios postulados, ignorando suas inconsistências e 
fraquezas. Bogdánov torna-se assim uma "alternativa" para Lenin, sem se aperceberem - ou se importarem - do fato de que tal possibilidade nunca esteve posta à mesa. Não é possível "voltar a fita" da História. Exemplos abundam: Pannekoek (2003) critica o furor retórico que Lenin emprega em "Materialismo e Empiriocriticismo", mais interessado em desqualificar seus adversários frente a um hipotético júri do que em desconstruir seus argumentos; Ballestrem (1969: 305) afirma que Lenin "culpou por associação" Bogdánov e Bazaróv a partir de sua crítica ao empirismo de Mach e Avenarius, sem dar conta da obra per-se de seus adversários; Sochor (1988:102) condena o uso do discurso de autoridade por Lenin, que utilizou exaustivamente passagens de Engels sem contextualizá-las nos debates que a produziram no final do século XIX.

É possível concordar com todas essas críticas e ainda assim frisar que seus autores acabam por reduzir "Materialismo e Empiriocriticismo" e seu autor a aspectos unidimensionais do debate teórico na qual ambos se inserem. Se é fato que a obra cumpre um papel político e tático na disputa do centro bolchevique, também é importante o papel que essa obra exerceu na produção intelectual posterior de toda a Intelligentsia russa. Seu discurso vitriólico é forma. Sua essência é a defesa do materialismo dialético como epistemologia científica, razão pela qual Lenin recorre constantemente a Engels.

Essas recorrências não são meras legitimações do marxismo dialético, ameaçado pelo revisionismo machiano. A partir de sua teoria do reflexo, Lenin interpretará o próprio processo do devir histórico à luz da lei da transformação da quantidade em qualidade. De acordo com Engels:

“(..) na Natureza, de um modo que se mantém sempre igual em cada caso particular, as mudanças qualitativas só se podem realizar por acréscimos ou por subtração quantitativa de matéria ou de movimento (a chamada energia)." (Engels, 1979:35)

A partir da lei de transformação da qualidade em quantidade, as verdades relativas, limitadas às descobertas particulares e restritas a critérios de verdades móveis e imanentes, acumulam-se em um processo de superação do erro em direção à verdade até o momento em que produzem uma transformação qualitativa, que supera e transcende os mesmos limites, podendo estabelecer 
um saber total sobre o objeto ou ampliar as fronteiras de um dado sistema de pensamento.

A partir dos fundamentos do materialismo dialético de Engels, Lenin foi muito além de uma simples defesa da ortodoxia. Ele ancorou uma visão organizacional do Estado e da Revolução - sua práxis - em um substrato epistemológico alicerçado em sua teoria do conhecimento. A teoria do reflexo orientada pela lei de transformação da quantidade em qualidade conserva a condição essencial de auto-movimento no processo dialético entre as verdades relativa e absoluta. Lenin integra por meio do materialismo dialético uma teoria do conhecimento que se harmoniza com as concepções de absoluto ao mesmo tempo em que contorna a natureza estática dessa mesma categoria. A partir dessa base epistemológica Lenin definiu sua própria teoria de poder. A transformação da sociedade passa pela identificação na luta política de suas próprias contradições dialéticas. Armado da verdade relativa - das condições históricas presentes e objetivas, externas aos sujeitos mas apreendida por eles - é possível para a vanguarda atuar como catalisadora dessas contradições, acumulando-as até que atinjam "massa crítica" e produzam uma mudança qualitativa no sistema, produzindo assim a superação da contradição dialética em uma nova forma sistêmica.

"Materialismo e Empiriocriticismo" atua como marco em diversas instâncias. Em Lenin, marca o amadurecimento de suas ideias acerca do papel da vanguarda e dos fundamentos de sua teoria da revolução e do Estado. A tomada revolucionária do poder é o primeiro passo em direção ao socialismo. Sob a hegemonia da classe trabalhadora - liderada por sua vanguarda - o Estado orienta transformações quantitativas nas relações de produção que eventualmente produzem transformações qualitativas, metamorfoseando esse mesmo estado e suas classes constituintes em formas produtivamente superiores. Em 1911, em texto intitulado "Aqueles que nos liquidariam", Lenin definiu categoricamente o que entendia por hegemonia:

"A hegemonia da classe trabalhadora é a influência política que essa classe (e seus representantes) exercem sobre outros setores da população, auxiliando-os a se livrarem de sua democracia". (Lenin, 1977 : 79) 
O sentido de hegemonia em Lenin é essencialmente político. Sua condição é a tomada e manutenção do poder e, a partir dele, a construção do socialismo por meio de transformações quantitativas em direção à superação da sociedade de classes. A supremacia do aspecto político sobre outras dimensões sociais da hegemonia (arte, cultura, educação, etc...) exerceu forte influência nas diversas formas de atuação do Estado soviético junto à sociedade. Retornaremos a esse tema posteriormente ao tratar da Organização Científica do Trabalho nos anos iniciais da Rússia Soviética e do debate que empreendeu Bogdánov naquele contexto. Dessa forma poderemos clarear a proposta de organização do Estado, das classes e da produção em "Estrela Vermelha" . Passaremos agora à concepção bogdanoviana de hegemonia e de que forma ela se desvia do teor político da concepção leninista de hegemonia ao se fundamentar no Empiriomonismo.

\subsection{Empiriocriticismo ou Empiriomonismo?}

Em 1910, Bogdánov publicou sua resposta à "Materialismo e Empiriocriticismo" na forma de um apêndice à obra "A Queda d Grande Fetichismo". Sob o título "Fé e Ciência" (FE), Bogdánov buscou defender suas posições enquanto teórico marxista ao mesmo tempo em que acusou Lenin de autoritarismo e fideísmo. De acordo com Ballestrem (1969:294), a publicação de $F E$ teve reduzido impacto, um sinal de que esse ciclo de debates havia se encerrado. Dada a dificuldade em acessar esse documento, podemos acompanhar os argumentos de Bogdánov somente através de fontes secundárias, notadamente os trabalhos de Ballestrem (1969), Marot (1993) e Brandist (2015).

Bogdánov buscou demonstrar em $F E$ as principais diferenças entre seu pensamento e aquele de Mach, de forma a dimirir os ataques de Lenin expressos em ME. De acordo com Ballestrem (1969 : 294), Bogdánov concentrou-se em dois pontos principais: a relação entre as experiências física e psíquica; e o papel organizacional ativo do pensamento. Ainda que tenhamos nos debruçado de forma pormenorizada sobre o empiriomonismo de Bogdánov no segundo capítulo desta Dissertação, retomaremos alguns conceitos para ressal- 
tar o que há de específico em seu sistema de pensamento quando comparado ao empiriocriticismo de Mach.

Em acordo com a crítica de Lenin, Bogdánov concorda que a ausência de um referencial de objetividade acaba por produzir no empiriocriticismo um supremo relativismo. Mach não buscou explicar como se daria o processo de formação dos complexos de elementos, ignorando nesse processo qualquer possibilidade de diferenciação entre as infinitas possibilidades de combinação desses complexos. Bogdánov, por sua vez, ressalta que esse não é o caso quando se trata do empiriomonismo. A partir de uma análise genética da interação sujeito-objeto, Bogdánov elaborou uma taxonomia que orienta a experiência em termos de organização. Originada no caos dos elementos, a experiência é apropriada por graus diferentes de organização desses elementos: a experiência psíquica-subjetiva, produzida pela apropriação de indivíduos; a experiência física-objetiva, produzida pela apropriação coletiva; e o conhecimento, produzido pela apropriação social (Ballestrem, 1969 : 296).

Diferentemente de Mach, Bogdánov dedicou atenção especial ao processo de organização da experiência. Esse fato se perde na análise de Marot ao questionar a obra filosófica de Bogdánov como fundamentalmente subjetivista (Marot, 1993 : 157). Ainda que tenha negado a condição ontológica da matéria, a existência de níveis organizacionais da experiência obrigou Bogdánov a estabelecer uma condição de primazia dos elementos externos na constituição da consciência. Tal primazia, no entanto, não implica existência ontológica: Esses elementos externos são desprovidos de sentido - neutros - e sua fisicalidade é condicionada pela experiência social. Essa experiência por sua vez se desenvolve através da reprodução social dos seres humanos, que na prática laboral organizam o caos dos elementos (a natureza) transformando-a e sendo transformado por ela.

Em seu esforço coletivo contra o mundo da resistência, expresso pela atividade laboral, a humanidade avança a partir de níveis mais elementares da experiência para níveis cada vez mais avançados. Nesse processo a experiência se desenvolve em direção à unidade físico-psíquica, saltando entre formas organizativas da produção e de suas estruturas ideológicas, que por sua vez reforçam as formas organizacionais do labor. Esse processo é dirigido 
evolutivamente, uma vez que a natureza atua como elemento regulador entre diferentes formas de organização laboral, selecionando as mais eficientes, econômicas e adaptáveis. No esforço imposto pelo trabalho social frente à resistência da matéria, a humanidade se transforma, psíquica e fisicamente.

Poucos autores, com exceção de Krementsov (2011 : 122) e Wark (2015 : 88), perceberam esse elemento lamarckiano no sistema organizativo de Bogdánov. Em seu esforço de reprodução social empreendido contra o mundo da resistência (matéria), a humanidade adquire características - elementos - que contribuem nesse esforço. Definidos por Bogdánov como "cristais" de labor, tais elementos são organizados pela experiência coletiva da humanidade em forma de conhecimento e assim são transmitidos para as gerações seguintes, do mesmo modo que ocorre com as girafas de Lamarck que, em seu esforço para atingir as copas mais altas, esticam seus pescoços e transmitem essas transformações para seus descendentes ${ }^{2}$.

É digno de nota o fato de que tal influência, ainda que tenha passado desapercebida entre os estudiosos, não o foi para escritores de FC. Kim Stanley Robinson, um dos principais expoentes da literatura utópica contemporânea, referenciou esse debate em sua mais conhecida obra, a volumosa "trilogia de Marte". Em "Marte Vermelho" acompanhamos a primeira missão de colonização do planeta vermelho, composta por uma centena de cientistas, cuja missão é não apenas viabilizar a colonização, como também elaborar um gigantesco projeto de engenharia visando à terraforma de Marte. No decorrer da narrativa acompanhamos debates de naturezas diversas - filosóficos, políticos, éticos - empreendidos pelos colonizadores. Entre esses debates, destaca-se a natureza da futura sociedade marciana, tema que polariza a maior parte dos cientistas. Entre as várias posições expressas na trama destaca o radicalismo

\footnotetext{
2 A teoria das características adquiridas de Jean Baptiste Lamarck exerceu considerável influência sobre a Intelligentsia russa. No centro desse fenômeno encontra-se a constituição de um novo homem, que floresceria a partir da própria construção do socialismo. Sua gênese encontra-se pressuposta já na produção intelectual que marcou as gerações dos anos de 1850 e encontrou na teoria lamarckista uma fundamentação científica que justificava o esforço moral e comportamental que regrava a vida dos militantes revolucionários (Grahan, 1993:64). Por muito tempo desacreditada, em parte pela catástrofe do lisenkoísmo, a teoria lamarckista vem nos últimos anos sendo em parte reabilitada pela epigenética. Para mais informações sobre a influência do lamarckismo sobre a ciência russa, ver as obras de Loren Grahan: "Science in Russia and the Soviet Union: a Short History" e "Lysenko's Ghost: Epigenetics and Russia".
} 
de um engenheiro mecânico russo: Arkady Bogdánov ${ }^{3}$. Expansivo e dotado de personalidade magnética, Arkady Bogdánov defende que os colonos rompam todos os laços com a Terra e, a partir do isolamento, construam uma sociedade absolutamente nova, cujos valores e visão-de-mundo correspondam à experiência vivenciada pelos colonos no processo de terraformação do planeta Marte. Em determinado momento da obra, ao discordar sobre o papel da evolução na adaptação dos colonos, Arkady Bogdanov exclama:

"Não, não, não, não! História não é evolução! Essa é uma falsa analogia! Evolução é uma questão de ambiente e probabilidade, agindo por milhões de anos. Mas história é uma questão de ambiente e escolha, agindo dentro de gerações e, às vezes, dentro de alguns anos, ou meses, ou dias! A história é lamarckiana!" (Robinson, 1993:88)

É possível identificar esse aspecto lamarckiano da teoria de desenvolvimento organizacional em "Estrela Vermelha". Em visita ao museu, Leonid descobre que o corpo humano é o principal motif da escultura marciana. Ao estudar as obras, Leonid descreve as diferenças entre os corpos marcianos e terráqueos: enquanto as mulheres marcianas tem ombros mais largos, os homens marcianos detêm músculos menos proeminentes e pélvis mais estreita. Tais características, de acordo com o viajante, "tendem a neutralizar as diferenças físicas entre os sexos" (Bogdanov, 1984 [1908]:76). No entanto, Leonid ressalta que tal semelhança corresponde somente "na época mais recente, na era da livre evolução humana". Ao descrever as estátuas mais antigas:

"(...) que datam até o período capitalista as distinções são muito mais óbvias. É evidente que a escravização da mulher no lar e a luta febril pela sobrevivência por parte dos homens devem ser responsabilizadas pelas discrepâncias físicas entre os sexos." (Bogdanov, 1984 [1908] : 76)

3 Fredric Jameson dedicou boa parte de sua obra "Archaeologies of the Future" a analisar "Marte Vermelho", enquanto uma nova forma de utopia crítica. Ao analisar especificamente os personagens, Jameson aponta que os nomes escolhidos por Robinson para seus personagens são "utopicamente auto-referenciais" (Jameson, 2005 : 404). Em seu interessante estudo "Molecular Red", Mckenzie Wark propõe que a "Trilogia de Marte" seja lida como uma continuação de "Estrela Vermelha" (Wark, 2015 : 112). De fato, diversos personagens da trama de Robinson são nomeados em homenagem a revolucionários conhecidos ou de importantes personagens da FC. Enquanto "Bogdanov" é autoreferencial, seu primeiro nome - Arkady - é possivelmente uma referência ao escritor Arkady Strugatski que, ao lado de seu irmão Boris, foi o autor de FC soviético mais reconhecido no Ocidente 
Como podemos ver Bogdánov descreveu as semelhanças entre os corpos marcianos feminino e masculino como fruto dos tempos presentes. Em um espaço de algumas gerações, sob a liberação do trabalho alienado, o devir histórico determinado por novas relações de produção alteraram fisicamente a constituição biológica marciana. A condição sociomórfica expressa pelo coletivismo da maquinofatura determinava os corpos. ${ }^{4}$

Essa influência lamarckiana encontra-se de acordo não somente com a epistemologia positivista de Bogdánov que busca extrair das ciências naturais leis que pudessem ser aplicadas à história e à economia, como também dialoga com a tradição voluntarista da Intelligentsia idealista russa. Cercado esse contexto, é possível agora afirmar que, ainda que não dialética, a teoria do conhecimento de Bogdánov é tampouco subjetiva. O mundo externo - o reino da matéria - é para Bogdánov objetivo, no sentido que dele parte toda a resistência imposta aos esforços humanos, individuais ou coletivos, resistência que por sua vez só pode ser transposta pelo caráter social do trabalho. Bogdánov opera sua concepção de matéria em correlação precisa com a ideia de trabalho social, i.e. a atividade social necessária para superar a resistência da matéria e garantir a reprodução da vida social (Bogdanov, 2016 [1913] : 43). Ainda que Lenin aponte acertadamente para a natureza solipsista do empiriocriticismo de Mach, o mesmo não pode ser dito do empiriomonismo de Bogdánov, uma vez que ele alicerça sua concepção de experiência em um nível organizacional inexistente na filosofia machiana: o nível organizacional do conhecimento, que opera por meio da categoria marxiana de trabalho social (Bogdanov, 2016 [1913]: 44).

Ainda que Bogdánov rejeite peremptoriamente a existência de quaisquer categorias absolutas, sua filosofia condiciona o desenvolvimento histórico a partir de relações econômicas objetivas. Tal objetividade, no entanto, é

4 Em sua obra "Alexandra Kollontai: a biography", Cathy Porter aponta para a longa relação de amizade e colaboração estabelecida entre Bogdánov e Kollontai desde 1896 e que se estendeu até os anos das Escolas do Partido em Capri e Bolonha, onde Kollontai ministrou diversos cursos sob a direção de Bogdánov. Porter aponta a proximidade entre ambos, bem como a influência da filosofia de Bogdánov e Bazarov em seus escritos que examinaram a influência das instituições capitalistas sobre os os sentimentos e instintos sexuais (Porter, 1980:171). O papel proeminente de personagens femininas, a igualdade sexual e o debate acerca do amor não-normativo presente em "Estrela Vermelha" nos induz a postular que essa fora uma relação de colaboração que influenciou decididamente ambos os revolucionários. 
determinada não pela expressão ontológica do mundo, mas pela natureza social da forma com a qual os homens se realizam ao interagir com ele. Assim como Marx, Bogdánov condicionou o devir histórico à reprodução social dos homens, realizada a partir do trabalho. É por meio do trabalho que os homens fazem avançar a capacidade técnica das forças produtivas, das quais emergem complexos de elementos que, na forma de conhecimento, reforçam essas mesmas relações de produção (Rowley, 1996:5). É por meio desse processo, denominado por ele de "sociomorfismo", que Bogdánov produz uma teoria do conhecimento científico sem depender das categorias absolutas. A partir da prática social do trabalho, os homens instam na consciência formas ideológicas, as quais por sua vez organizam os elementos da experiência - o conhecimento (Brandist, 2015:122). Bogdánov partiu do empiriocriticismo e do marxismo para produzir conclusões autorais bastante distintas daquelas apresentadas por Mach. Bogdánov poderia ser acusado de um mau marxista, mas apenas com algum esforço de machiano.

A tentativa de dar conta das teorias evolucionistas - darwinista e lamarckiana - em seu sistema nos mostra que Bogdánov mostrou uma preocupação especial com as permanências, com os processos de desenvolvimento, com a resiliência do fetichismo. Sochor $(1988$ : 49) propõe a partir dessas preocupações a aproximação do pensamento de Bogdánov ao funcionalismo estruturalista, aproximação essa que se deu nos anos que se seguiram ao fim do círculo vperedista. Verifiquemos agora como sua teoria organizacional se desenvolveu, de que forma ela contribui para compreender como Bogdánov entendia o conceito de hegemonia e quais elementos já se encontravam presentes em "status nascendi" na narrativa de "Estrela Vermelha".

\subsection{Entre a cultura e a revolução}

Em sua obra "Revolution and Culture: The Bogdánov-Lenin Controverse", Zenovia Sochor atribuiu ao debate que dividiu o centro bolchevique em 1909 a justaposição de conceitos profundamente imbricados naquilo que a tradição radical russa entedia como formativos de um processo revolucionário: política e cultura (Sochor, 1988:5). Essa imbricação acabava por manifestar-se no seio 
dos debates políticos como efeito causal de um antinomia de primeira ordem, cuja presença, de forma mais ou menos explícita em contextos históricos diferentes, é constante na tradição radical russa: a tensão entre o velho e o novo.

Esse dilema - a construção de um novo mundo e de um novo homem a partir dos escombros do velho mundo - sempre fora preocupação constante dos movimentos socialistas revolucionários. O novo existe potencialmente enquanto possibilidade expressa no devir, mas não se pode realizar para fora do mundo concreto, do velho mundo. Essa questão esteve, a título de exemplo, no centro do debate da I Internacional dos Trabalhadores e manteve-se presente nos estudos posteriores de Marx. Em excerto no qual fez uma leitura crítica da obra "Estatismo e Anarquia" de Bakunin, Marx questionou a possibilidade de dissolução imediata do Estado proposta pelo revolucionário russo:

\begin{abstract}
“(...) como o proletariado, durante o período de luta para derrubar a antiga sociedade, ainda age com base na antiga sociedade e, por conseguinte, continua a se mover entre formas politicas que mais ou menos pertenciam àquela sociedade, ele ainda não encontra, durante esse período, sua constituição definitiva e emprega meios para sua libertação que, depois dessa libertação, deixam de existir." (Marx, $2012: 117)$
\end{abstract}

A antinomia entre o velho e o novo é um dilema que estimulou debates entre os principais nomes do socialismo europeu no século XIX. No capítulo anterior, pudemos acompanhar de que maneira esse debate se configurou em relação às particularidades do contexto russo e a partir da luta contra a autocracia. Tal resposta implicaria não somente a superação da sociedade de classes mas, principalmente, que socialismo seria possível a partir das condições concretas dadas historicamente aos seres humanos, condições essas que deveriam servir como ponto de partida para a revolução social, mas cuja existência é dada e não escolhida.

A construção do socialismo enquanto etapa transitória para uma sociedade sem classes é, para este trabalho, o cerne do cisma que rompeu o centro bolchevique em 1909 e colocou suas lideranças mais proeminentes em campos 
opostos. Não deixa de ser irônico ver que o excerto da resposta de Marx para Bakunin poderia ser utilizado como analogia tanto para as posições de Lenin, quanto as posições de Bogdánov. Para aquele, a citação de Marx é (como é de fato) uma afirmativa: o proletariado age com as ferramentas existentes em sua luta para derrubar a antiga sociedade; para o último, a mesma afirmativa vale, mas com o sinal trocado - uma interrogação: ele ainda não encontra, durante esse período, sua constituição definitiva e, portanto, ainda age com base na antiga sociedade?

Como exposto anteriormente, Lenin opera a partir da dominação política como força motriz para o processo de transformação revolucionária. A ditadura revolucionária do proletariado se define pela hegemonia política da classe trabalhadora e é o fundamento do estado socialista e sua constituição organizacional. A partir da construção do poder político, a classe trabalhadora através de suas instituições transforma as relações de produção, suprimindo as diversas classes sociais nesse processo, incluindo aí o próprio proletariado. Cabe notar que o termo ditadura não carrega para Lenin e Marx o sentido disnômico com o qual o compreendemos no presente. O uso do termo "ditadura" na obra marxiana imiscui-se com a ideia de transitoriedade e hegemonia de uma classe sobre a outra, que não necessariamente implica a supressão de processos democráticos. Ao contrário, tal hegemonia seria caracterizada pela intensificação da participação social no processo político, como bem aponta Engels, em prefácio da edição francesa de 1891 da "Guerra Civil na França": "Pois bem, senhores, quereis saber como é essa ditadura? Olhai para a Comuna de Paris. Tal foi a ditadura do proletariado" (Marx, 2011a:117). Tanto em Marx como em Lenin a ditadura se define pela condição da transitoriedade do poder político revolucionário, cuja hegemonia é exercida pela classe trabalhadora. Em "Estado e Revolução" Lenin equalizou a ditadura do proletariado à concepção de supremacia política, definindo-a como "(...) um poder proletário exercido sem partilha e apoiado diretamente na força das massas em armas" (Lenin, 2011:60).

Bogdánov nunca negou a importância do processo político na constituição do Estado Revolucionário. Ambos concordavam desde o começo de sua aliança em 1904 sobre a necessidade de uma vanguarda profissional, composta 
por agentes revolucionários integralmente dedicados à revolução. Ainda que discordassem do espontaneísmo das massas enquanto força revolucionária, ambos diferiam em suas causas: para Lenin, sem uma vanguarda que direcionasse o processo revolucionário, o proletariado fatalmente se limitaria às demandas economicistas, características do programa maximalista alemão (Krausz, 2015 : 32); Bogdánov, por sua vez, acreditava não ser possível para os trabalhadores, fragmentados em sua experiência subjetiva das relações de trabalho que os oprimiam, superarem tal condição sem o apoio da Intelligentsia organizada em uma vanguarda (Jensen, 1978:45).

Foi a partir de sua concepção empiriomonista de experiência que Bogdánov buscou compreender os processos sociais e históricos a partir de fundamentos organizacionais. Todo o universo - desde suas formas inorgânicas mais elementares até a atividade orgânica mais sofisticada - poderia ser descrito por meio de modelos organizacionais. A ciência é a experiência organizada de uma determinada sociedade em um dado momento histórico, cuja forma supraestrutural emerge das relações sociais de labor. A partir do trabalho social os homens produzem modelos cognitivos que substituem os fenômenos observados. Esses modelos são substituídos por complexos de elementos cada vez mais abstratos e instáveis conforme as forças produtivas fazem avançar o esforço social frente à resistência (Gare, $2000 b$ :236).

Essa abordagem organizacional do conhecimento permitiu que Bogdánov avançasse a partir da concepção empiriomonista da experiência em direção à formulação teórica de uma Ciência Universal Organizacional, a Tektologia. Seu objetivo era estabelecer um conjunto científico e empírico de postulados que permitissem que modelos cognitivos fossem livre-cambiados entre os diversos campos científicos a partir da análise sistêmica de sua organização. Para seu criador, a Tektologia teria como função:

“(...) clarificar os modos de organização que percebemos existir na natureza e na atividade humana; então deve generalizar e sistematizar esses modos; além disso, deve explicá-los, i.e. propor esquemas abstratos de suas tendências e leis; finalmente, baseado nesses esquemas, determinar a direção de métodos organizacionais e seu papel no processo universal." (Bogdanov, 1980 : ii) 
Como vimos anteriormente no Capítulo 2, Bogdánov partiu desse conceito e tentou a partir daí elaborar um modelo histórico que desse conta da evolução das forças produtivas a partir de seu método de substituição. Seu objetivo era menos explicar o processo evolutivo dessas forças e mais demonstrar a partir desse modelo o surgimento, desenvolvimento e transformação das formas organizativas da experiência que derivavam do processo social do trabalho. Tais elementos comporiam o arcabouço ideológico e teriam por função organizar e controlar as atividades práticas de uma dada sociedade. De acordo com Sochor (1988: 28), Bogdánov se utilizava de uma concepção ampla de ideologia, que abarcava fenômenos como a fala, cognição, arte, costumes, leis regras de propriedade e moralidade. A autora ainda aponta para as semelhanças entre a concepção de ideologia enquanto princípio organizativo compartilhadas entre Bogdánov e os antropólogos sociais como Clifford Geertz. Esse último compreendia as formas ideológicas como "programas" que fornecem as plantas para a organização dos processos psicológicos e sociais (Sochor, 1988:32). Utilizando-se de metáforas extraídas da biologia, Bogdánov argumentou que a ideologia tinha uma função paralela ao papel do cérebro em um organismo:

"Auxiliar no desenvolvimento da consciência de uma determinada classe significa desenvolver o alicerce de sua organização, participar na formação de um cérebro que deverá controlar aquela poderosa máquina." (Bogdánov, 1914, apud Sochor 1988:30)

Contra a concepção culturalista de ideologia defendida por Bogdánov atuava uma tradição social-democrata que dedicava aos fenômenos da superestrutura um papel secundário. Para Lenin - e Marx - os sistemas ideológicos expressam os interesses e pontos-de-vista de uma determinada classe. A partir da vanguarda, seria possível elevar a consciência da classe trabalhadora e guiá-la em direção à revolução. Sua concepção é orientada de acordo com uma práxis que visa à luta de classes. Bogdánov, por sua vez, acreditava que as ideologias transcendem a luta política, ainda que sejam determinantes para as formas com que a luta de classes se expressa nos momentos de crise. Para ele, o desenvolvimento de uma nova ideologia não tinha tão somente 
fins políticos imediatos, mas era fundamental para a vitória do socialismo no futuro.

De acordo com Biggart (1990:64), Bogdánov defendeu que a teoria marxista apresentava diversas lacunas, hiatos que por sua vez eram ignorados por seus contemporâneos como elementos menores dentro da totalidade teórica. Ele questionou a primazia mecanicista da infraestrutura a partir da relação entre a propriedade privada - uma categoria jurídica-contratual - e as relações de produção - uma categoria econômica, infraestrutural. Bogdánov questionou a leitura ortodoxa de Plekhánov a partir da contradição que se insta ao não reconhecer a propriedade privada - em seu sentido formal-jurídico como elemento fundante do processo de acumulação capitalista. Essas observações somente foram possíveis no contexto da resistência historicamente exercida pela Intelligentsia bolchevique ao contexto hegemônico da interpretação ortodoxa da teoria marxista. Essa resistência se expressara na rota heterodoxa que Bogdánov tomou ao fazer uma leitura do marxismo a partir de fundamentos empiriocriticistas. Ao negar a dicotomia entre objetividade e subjetividade, Bogdánov recusou por consequência as primazias do ser social sobre a consciência social, bem como a precedência mecanicista da infraestrutura sobre a superestrutura. Para ele, esse hiato se replicava no próprio programa da social-democracia, dividido entre o programa mínimo que dirigia seus esforços para as batalhas políticas presentes - e o programa máximo - que delineava das tarefas futuras do proletariado. Bogdánov argumentava que não havia quaisquer correspondências entre os dois programas. Entre o proletariado revolucionário do presente e o proletariado mestre do futuro se estendia um abismo (Sochor, 1988: 38).

De acordo com Sochor sua leitura monística da experiência o levou a rejeitar toda e quaisquer formas de etapismo e marcou de forma decisiva suas reflexões sobre a revolução. Bogdánov se preocupou como nenhum outro social-democrata de seu tempo com o interregno entre a revolução e a constituição do comunismo. Diferentemente de Lenin - e Marx (Marx, 2012 : 43) - Bogdanóv enxergava a constituição do socialismo não como uma série de etapas mais ou menos definidas mas como um continuum (Sochor, 1988:40). Em artigo intitulado "Socialismo no Presente", publicado no 
Jornal Vpered em 1911, Bogdánov verbalizou essa convicção:

"A organização consciente da classe trabalhadora no presente e a organização socialista de toda a sociedade no futuro são momentos diferentes do mesmo processo, estágios diferentes do mesmo fenômeno." (Bogdanov, 1918b:np)

Bogdánov acreditava que a tarefa de construção do socialismo se iniciava antes do processo de revolução e se estenderia para muito além dele. Esse esforço deveria ser precedido pelo desenvolvimento de elementos ideológicos do socialismo no cerne da classe trabalhadora e que atuariam em suas relações internas, em suas condições da vida cotidiana e que extrapolariam as relações sociais de labor baseadas na cooperação da fábrica para todos os outros aspectos da vida social. A essa tarefa de construção dos elementos ideológicos do socialismo, Bogdánov nomeou como "Cultura Operária" ou "Proletkult". Ao defender a criação do "Proletkult" como fundamento programático do movimento revolucionário, Bogdánov buscou ocupar o hiato que entendia existir entre "o ideal socialista" e a "realidade de classe". De acordo com ele:

"O socialismo se tornará realidade quando não apenas o poder político e o "plano econômico", mas um novo mundo da cultura, com métodos novos e superiores, se opuser ao velho mundo cultural, com sua experiência de milênios e métodos bem estabelecidos. Para derrotar a espontaneidade social, a classe trabalhadora deve superar a espontaneidade de seu próprio desenvolvimento. Ele não pode dar ao mundo aquilo que ele próprio não possui (...) Não é um salto que leva do reino da necessidade para o reino da liberdade, mas um caminho difícil." (Bogdanov, 1918a)

A partir de uma concepção monística do processo de constituição do socialismo, Aleksandr Bogdánov ofereceu uma proposta de revolução distinta daquela propugnada pela teoria leninista. Bogdánov acreditava que o proletariado, desde seu surgimento, vinha desenvolvendo espontaneamente seu sistema ideológico-cultural. No entanto, esse processo era lento, porque desorganizado. Bogdánov acreditava ser papel da Intelligentsia prover de forma sistematizada as ferramentas organizativas com as quais os trabalhadores constituiriam um novo modelo cognitivo, uma nova cultura, uma 
nova ideologia. A cultura proletária é um conceito elástico que abarca o período anterior e posterior a tomada do poder. A revolução não era o único ato dramático, o ponto culminante das contradições econômicas e conflitos políticos. Era um processo que envolvia transformações multidimensionais incluindo aí a construção de uma nova cultura, fruto dos esforços laborais da classe trabalhadora, com a qual o sujeito-coletivo organizaria a construção do socialismo. Para Bogdánov, o Socialismo era, principalmente, uma questão de método (Bogdanov, 1918b).

\subsection{Sistemas, funções e elementos}

A constituição de uma cultura operária é o "frame" organizativo para a criação de uma visão de mundo operária, cuja natureza monística superaria aquilo que Bogdánov definiu como "o grande fetichismo", i.e. a cisão entre as experiências subjetiva e objetiva. Essa ruptura organiza em todas as esferas do conhecimento os elementos ideológicos que reforçam a visão de mundo burguesa, baseada na competição e hostilidade entre produtores e proprietários. A visão de mundo operária expressaria, ao contrário, as relações cooperativas características da maquinofatura e gestaria novos elementos ideológicos, expressos em uma cultura e ciência socialistas, cuja natureza é a integração da experiência total em um sistema monístico. Em sua teoria sociológica do conhecimento, Bogdánov compreendia a consciência social como resultante de dois níveis sistêmicos: tecnológico e o ideológico. O esforço empreendido contra a natureza gesta a tecnologia, i.e. a organização e utilização do conhecimento relacionado ao mundo externo. $\mathrm{O}$ avanço de formas tecnológicas cada vez mais complexas acaba por exigir formas organizacionais semelhantes em termos de complexidade, que reforçam e organizam os processos tecnológicos. Tecnologia e ideologia formam os elementos de um sistema mais amplo, que Bogdánov categoriza como cultura e que explica as regularidades presentes nas transformações sociais e preservadas na cultura cognitiva (Gare, 2000b : 235).

À luz desse quadro caberia à Intelligentsia atuar como um "catalisador", acelerando o processo de formação da cultura operária que de outra forma 
seria lento, caótico e custoso. De forma metódica, a Intelligentisa atuaria em duas frentes: no desenvolvimento de novos intelectuais advindos das fileiras trabalhadoras; e na criação de uma nova ciência, que se fundamentasse na organização de complexos de elementos reais ou ideais. Uma ciência universal da organização que buscaria abarcar métodos práticos e teóricos bem como os métodos do homem consciente e da natureza espontânea: a Tektologia. A tektologia forneceria todos os modelos cognitivos necessários para organizar a experiência coletiva, possibilitando que métodos de áreas específicas fossem livremente trocados entre diferentes campos do conhecimento. Todos os campos de conhecimento poderiam ser reduzidos a processos organizativos comuns (Sochor, 1988:41).

Bogdánov partiu de sua concepção monística de experiência para compreender todos os processos existentes em termos sistêmicos e organizativos: política é a forma organizacional do poder; cultura é a forma organizacional da ideologia; economia é a forma organizacional do trabalho social. Para ele, o universo é composto por uma infinidade de "sistemas" conectados organicamente e diferenciados por níveis diversos de organização. Bogdánov define como "sistema" qualquer combinação de elementos em estado de interação com o ambiente cujas partes podem ser decompostas e individualmente estudadas (Gorelik, 1980:329). A combinação de atividades e resistências presentes no interior de um sistema correspondem ao seu grau de organização: se a soma das forças supera as resistências, menores são as contradições em seu interior e maior é o seu nível organizacional (Bogdanov, 1980:41).

Todo processo organizacional, de acordo com Bogdánov, opera por meio de dois mecanismos tektológicos: formativo e regulatório. Os mecanismos formativos são categorizados em conjuntivos (união ou destruição de elementos através de amalgamento); ingressivos (ligação entre complexos distintos que compõem um sistema); vinculatórios (ponto de contato entre sistemas diversos); e críticos (perda de diferenciação entre os limites de fronteira entre um sistema e seu ambiente). Os mecanismos regulatórios dão conta da resiliência e adaptabilidade de um sistema em relação ao seu ambiente e podem ser de natureza seletiva (que processa seletivamente formas convergentes/divergentes, estabilidade e transformações estruturais); e reguladora, que 
garantem o equilíbrio dinâmico entre os elementos que compõem o sistema (Gorelik, $1980: 330$ ).

A partir dessas categorias e de suas múltiplas combinações, Bogdánov buscou descrever os processos gerais e universais de uma teoria de sistemas. Seu trabalho resultou na publicação de "Tektologia: uma ciência universal organizacional", dividida em três grandes volumes e publicada entre 1916 e $1920^{5}$. Ainda que fascinante enquanto esforço intelectual, não é objeto desse trabalho fazer uma análise pormenorizada de "Tektologia". Nos interessa especialmente o papel que Bogdánov reservou aos processos regulatórios. De acordo com ele, tais processos são divididos entre as funções de manutenção - cujo processo seletivo busca conservar a forma dos elementos dentro do sistema - e desenvolvimento - cujo processo seletivo atua a partir da evolução de elementos do sistema em resposta às mudanças de equilíbrio entre um dado sistema e seu ambiente (Bogdanov, 1980:72). No curso de seu desenvolvimento um sistema pode adquirir formas distintas, tornando-se mais complexo e heterogêneo (seleção positiva) ou mais simples e homogêneo (seleção negativa). Ainda nesse processo, determinados elementos acabam por acumular, em relação à totalidade do sistema, um determinado quantum de atividade, acabando por influenciar todos os demais elementos. Bogdánov denomina esse processo de centralização das atividades em um determinado complexo de elementos como "egressivo". Além dele - e fundamental para a manutenção da estabilidade de um dado sistema - encontram-se os elementos "degressivos", os quais formam a estrutura esqueletal de um determinado sistema, garantindo sua resiliência organizacional frente às situações de crise provenientes de mudanças abruptas no meio (Bogdanov, 1980: 82).

Essa última classe de elementos nos interessa especialmente. Os sistemas ideológicos se enquadram na categoria dos elementos degressivos em um dado sistema social. Tais sistemas operam de forma a reforçar a estabilidade organizacional das atividades vitais da sociedade e demonstram por sua função uma pendência interna em direção à rigidez ou ossificação. Esses sistemas surgem a partir das atividades social-laborais, mas em seu processo

\footnotetext{
5 A redescoberta de Bogdánov a partir dos anos 1970 atraiu sobremaneira a atenção de estudiosos do campo da cibernética e Teoria Geral dos Sistemas. Para mais informações sobre a Tektologia, ver Gare (2000b,a); Gorelik (1980, 1983); Belykh (1990, 1989); Bogdanov (1980).
} 
de desenvolvimento tornam-se mais conservadores do que sua base. Uma vez que eles agem como uma restrição e um obstáculo ao progresso, acabam por estabelecer as condições para uma mudança de forma estrutural:

\begin{abstract}
“(...) opiniões, teorias e dogmas, assim como regras, leis e outras normas são formadas a partir de palavras-conceitos; complexos artísticos são formados a partir de símbolos especiais da arte. Consequentemente a natureza das ideologias é geralmente degressiva, esqueletal, com todas as características implicadas. (...) Em ciência e filosofia, a terminologia convencional porém obsoleta impede o domínio sobre novos materiais e distorce o significado de novos fatos, os quais não podem ser expressados de forma plena e precisa. Essa contradição aparece de forma ainda mais vívida no desenvolvimento de complexos mais sofisticados - ideias, normas e seus sistemas. O termo "ossificação do dogma", utilizado em relação a doutrinas religiosas, científicas, jurídicas, políticas e sociais, não à toa é emprestado da fisiologia do esqueleto: seu inerente atraso no processo de evolução a partir do conteúdo da vivência; seu papel conservador é tektologicamente o mesmo que realiza um esqueleto." (Bogdanov, $1980: 195)$
\end{abstract}

No centro da relação entre processos egressivos e degressivos encontra-se a teoria do equilíbrio dinâmico de Bogdánov. A força motriz que produz alterações em um sistema vem do ambiente, que altera tanto a estrutura interna do sistema quanto a sua relação e o ambiente em si. Ao mesmo tempo cada distúrbio do equilíbrio cria pressão para estabelecimento de um novo equilíbrio. Esse processo é dotado de um equilíbrio dinâmico e um biregulador (semelhante ao conceito de feedback na cibernética) que busca a manutenção da ordem. Os sistemas ideológicos operam como sistemas bi-reguladores, reforçando a estrutura do sistema e, frente a alterações drásticas de ambiente, reduzindo o impacto dos processos formativos de crise, forçando o sistema à condição de equilíbrio de forma lenta e gradual (Bogdanov, 1980 : 212).

A partir de sua abordagem tektológica, Bogdánov intentou desenvolver categorias próprias que explicassem sob a lógica da organização as lacunas que acreditava existir na leitura da obra marxiana defendida pela socialdemocracia. A transformação das forças produtivas por meio da tecnologia força alterações nos diversos sistemas que compõem o tecido social, estimulando novas relações de produção e novos complexos ideológicos que visam 
a adaptar o sistema social a essas transformações ou mesmo impedi-las. A partir dessa constatação, Bogdánov acreditava que uma revolução política não necessariamente produziria os elementos necessários para a constituição do socialismo. Sem uma cultura operária e uma nova ciência que desse conta da ampla transformação sócio-cultural que se espera e deseja a partir da revolução, sistemas ideológicos pertencentes à visão de mundo burguesa ainda se fariam presentes, distorcendo e adiando o processo de constituição do socialismo.

Não bastava a luta revolucionária. Era necessária a criação de uma cultura e ciência operárias. Se por um lado essa era tarefa dos trabalhadores tão somente, Bogdánov acreditava que caberia à Intelligentsia um papel ativo nesse processo: produzir por meio do partido as condições iniciais para o desenvolvimento desses alicerces. Como exposto anteriormente, assim como Lenin, Bogdánov não acreditava no espontaneísmo das massas. O socialismo era uma questão de método, que deveria ser aplicado pelos elementos mais preparados cientificamente - a Intelligentsia radical burguesa - de forma a acelerar as transformações culturais dos trabalhadores e produzir ali novos intelectuais, cujo papel seria substituir a Intelligentsia burguesa enquanto vanguarda revolucionária.

As diferenças entre Lenin e Bogdánov, diferentemente daquilo que defenderam diversos estudiosos a partir de leituras isoladas desse debate - já citados no começo dessa análise - não são tão somente táticas, políticas ou programáticas. São acima de tudo organizacionais. Essa diferença expressouse de forma inegável a partir do debate acerca da reorganização das forças produtivas da Rússia e das implicações desse processo para o desenvolvimento da cultura operária. Como vimos no capítulo anterior, a ascensão da socialdemocracia russa tornou o papel da industrialização no desenvolvimento russo um fato inevitável, cujas vantagens não ocultavam aos olhos de muitos os riscos inerentes. Tentaremos expôr nas próximas páginas um panorama sobre a recepção de intelectuais socialistas ao taylorismo enquanto projeto cultural e de que forma Bogdánov dialogou com esse cenário a partir da organização produtiva marciana. Esse debate é fundamental para entender os elementos embrionários de seu rico pensamento em "Estrela Vermelha" e de que forma 
relacionam-se os conceitos de classe, produção e cultura.

\subsection{Nauchnaya Organizatsia Truda - NOT}

O taylorismo - conjunto de normas de gerenciamento produtivo e padronização da força de trabalho proposta por Frederick Taylor que se desenvolveu historicamente a partir da formação dos grandes trustes capitalistas americanos no final do século XIX - atuou como fundamento teórico-metodológico para o salto produtivo dado pela produção capitalista americana na passagem entre os séculos XIX e XX e foi objeto de intenso debate entre a Intelligentsia russa nas primeiras duas décadas do século XX. A obra de Taylor ia ao encontro dos anseios políticos de diversos revolucionários russos, que viam na organização racional do trabalho social - um escopo organizacional superior ao espaço restrito pelo chão-da-fábrica proposto por F. Taylor - a possibilidade de superar quantitativa e qualitativamente o modo de produção capitalista, marcado por relações de produção e consumo anárquicas e, por isso, sujeita às constantes crises de produção e demanda. Além disso, a organização científica do trabalho abria para muitos intelectuais possibilidades utópicas de engenharia social e constituição de uma autêntica cultura proletária, adequada às formas organizacionais de produção socialmente controladas e por isso superiores à condição alienada e hostil da produção capitalista (Rogger, 1981:385).

Não eram apenas as possibilidades de transformação social subjacentes às técnicas de gerenciamento científico que povoavam a imaginação da Intelligentsia russa. Atrelado ao interesse pelo taylorismo encontrava-se uma declarada admiração pelos Estados Unidos e a um conjunto de valores que compunham no imaginário revolucionário o cerne de sua produção capitalista. Para importantes nomes da histórica Revolução Russa de 1917, como Bukharin e Trotski, os Estados Unidos incorporavam valores como competência, pontualidade e precisão. Ser americano era trabalhar com energia e produtividade; evitar desperdício de materiais e energia; ser dotado de presteza e inventividade; gozar de um espírito prático, pragmático e pouco burocrático. "Fordzatsia" era, de acordo com Walter Durandy (1928, apud 
Rogger 1981:7), a palavra de poder que exprimia o fascínio que o capitalismo americano exercia sobre a sociedade soviética. Nesse mesmo artigo, Durandy lamenta que a "Rússia queira ser como os Estados Unidos e suas cidades como Chicago e Detroit". Interessante notar que esse fascínio se articula na língua russa através da adjetivação do nome de Henry Ford, como representação da forma americana de produzir, centrada na grande linha de montagem, no trabalhador de colarinho branco e no controle científico da força de trabalho.

A "fordzatsia" era uma promessa de transformação social que, aliada ao planejamento estatal, demonstraria a superioridade do modo de produção socialista. O "amerikanismo" não se restringia apenas à importação das técnicas tayloristas objetivando o salto produtivo da economia soviética, mas também comportava subsumida a essas técnicas uma perspectiva imagética, cultural e estética. Diversos artistas e poetas russos incorporaram, em maior ou menor grau, elementos desse americanismo. De acordo com Marc Slonim, era comum que autores circunscritos ao realismo soviético dos anos 1920 incorporassem elementos americanos em suas obras como ponto de contraste e identificação em relação à sociedade soviética e seus feitos. Como exemplo dessa condição de alteridade presente na arte russa dos anos 1920, que reconhece no capitalismo americano ideal e inimigo a ser suplantado, podemos citar a peça teatral "Temp" de Nicolai Pogodin (1900-1962). Nessa peça, que tem como cenário uma fábrica de tratores em Leningrado, acompanhamos o envolvimento do chefe do Bureau de Racionalização do Trabalho local - um jovem comunista chamado Maksinka - com os trabalhadores da fábrica, até então resistentes à implementação das técnicas de gerenciamento científico. Esses trabalhadores iniciam a narrativa melindrados pelo ritmo frenético de trabalho exigido por Carter, um engenheiro americano que trabalha, de acordo com eles, como um autômato. No desenvolvimento da história, os operários russos acabam por aceitar a ética de trabalho do engenheiro americano e terminam trabalhando em um "tempo" superior àquele demonstrado pelos trabalhadores americanos. Maksinka, o protagonista, passa suas noites "estudando fordismo, taylorismo e a Organização Científica do Labor (NOT)" e declara como objetivo "dominar o amerikanismo e imbuí-lo de princípios 
comunistas" (Slonim, $1961: 223)$.

Rogger (1981:390) defende que a ampla receptividade demonstrada pela Intelligentsia russa, notadamente os bolcheviques, perante esse conjunto de imagens e representações que aqui denominamos "amerikanismo" pode ser explicada por alguns fatores: o afastamento inevitável ocorrido entre as lideranças bolcheviques e o movimento socialista europeu fortemente influenciado pela social-democracia alemã, cuja interpretação etapista do processo de construção do socialismo ia de encontro aos anseios revolucionários da Intelligentsia russa; a necessidade urgente em recuperar a capacidade industrial devastada por duas guerras consecutivas; o forte pragmatismo que compunha o eixo imagético do "know-how" americano, o qual permitiu que o americanismo evadisse, ainda que parcialmente, das objeções de caráter ideológicos, atraindo intelectuais e engenheiros mais preocupados com as conquistas próximas incorporadas por ferrovias, pão e fornalhas e menos com as promessas distantes de coletivismo e igualdade; e o mito da igualdade de oportunidades e respeito sacralizado à liberdade de expressão, elementos atrativos para os intelectuais russos, dotados de uma longa tradição de combate à autocracia czarista.

Se de fato essa conjunção de fatores explica tal apreço, devemos ressaltar que não nos é possível ignorar o peso histórico e econômico exercido pela Europa Ocidental tanto no desenvolvimento capitalismo russo, através da injeção contínua por mais de quatro décadas de capitais estrangeiros franceses, ingleses e alemães para a compra de maquinários e obras de infraestrutura e que possibilitaram a constituição de grandes centros industriais em Baku, São Petersburgo e Moscou, quanto na constituição de uma longa tradição revolucionária, assentada na própria contemporaneidade europeia: podemos citar aqui de passagem a influência dos ideais iluministas franceses na origem do movimento dezembrista; a difusão do pensamento socialista francês e da filosofia alemã de Hegel, Feuerbach e Schiller e, finalmente, a adoção - a partir do final do século XIX - do sistema marxiano como eixo epistemológico central da vitoriosa geração de 1917. Não obstante, enquanto a Europa exerceu papel preponderante no desenvolvimento da Rússia e de sua intelectualidade, é certo que os Estados Unidos povoou a imaginação desses mesmos intelectuais com 
os símbolos e mitos de uma civilização industrial superior (Rogger, 1981 : 391). Dentre a profusão de símbolos, mitos e aparelhos ideológicos, o taylorismo foi talvez a principal vitrine desse "amerikanismo" e certamente o elemento mais impactante que a "fordzatsia" legou para a nascente Rússia Soviética.

Também é necessário salientar que esse interesse e atração pelas coisas da indústria, pelas possibilidades de transformação social advindas da uma sociedade industrial tem a sua própria história, marcada por rupturas e resistências. O grau de abertura para essas ideias variou não somente no tempo, mas também de acordo com a enorme diversidade política da Intelligentsia. Essa era composta por diferentes frações, cujos posicionamentos e debates produziram posições bastantes polarizadas em relação ao mundo industrial. Como vimos no capítulo anterior, para os narodniks e seus intelectuais o transplante do Capitalismo Industrial em solo russo acabaria por devorar a obshchina, a unidade fundamental da comuna russa, e levaria ao desaparecimento de suas tradições e da própria possibilidade de construção do socialismo fundado nessa unidade social, um socialismo de bases agrárias que evitaria os terríveis efeitos da industrialização sobre o povo russo.

A avaliação positiva do taylorismo estava distante de ser unanimidade. Muitos intelectuais demonstraram profundas reservas frente à brutalização inclemente imposta sobre o proletariado pelo avanço da divisão social do trabalho, a estandardização biomecânica visando à economia de esforços e imposição de metas e bônus por resultados (piece-rate system), características fundantes do sistema de Taylor. Nos anos de 1913 e 1914, Vladimir Lenin publicou, respectivamente, dois artigos no Jornal Pravda - diário então controlado pela facção bolchevique do Partido Operário Social Democrata Russo (POSDR) - em que elaborou reflexões profundamente críticas ao taylorismo. Ao mesmo tempo em que atestava o caráter vanguardista do capitalismo americano, Lenin salientava que seu pioneirismo se assenta:

\footnotetext{
"...em nove ou dez horas de trabalho, extrair do operário três vezes mais trabalho, drenando-o de todas as suas forças e, três vezes mais rapidamente, sugar cada gota da energia nervosa e psíquica do assalariado escravo" (Lenin, $1975: 594-595)$
}

Em 1914, ao descrever técnicas de estudo e padronização da biomecânica 
do labor, Lenin ponderou: "Todas essas vastas melhorias são introduzidas em detrimento dos trabalhadores, pois levam à exploração e opressão ainda maiores" (Lenin, 1972b:152).

Após a Revolução de Outubro de 1917 e durante a Guerra Civil Russa, seu posicionamento sofreu sensível alteração. Em abril de 1918 Lenin, em artigo publicado no exemplar de $\mathrm{n}^{0} 83$ do Pravda, transcrito a partir do panfleto "As tarefas imediatas do Governo Soviético", afirmou que:

"Os elementos progressivos do taylorismo, como a remuneração por produção (...) devem se tornar parte da rotina diária; eles devem ser empregados e testados. Em comparação com trabalhadores de nações industriais avançadas, o russo é um mau trabalhador. Nem poderia ser diferente, em face da persistência de reminiscências da servidão. A tarefa que deve ser definida pelo governo soviético para todo o povo é esta: aprenda a trabalhar. O sistema de Taylor, a última palavra do capitalismo a esse respeito, assim como todo o progresso capitalista, é uma combinação de brutalidade refinada da exploração burguesa e um conjunto que engloba os maiores avanços científicos no campo da análise dos movimento mecânicos laborais (...). A República Soviética deve adotar a todo custo tudo aquilo que é valioso entre os avanços da ciência e tecnologia desse campo (...). Nós devemos organizar na Rússia o estudo e ensino do sistema de Taylor e sistematicamente experimentá-lo e adaptá-lo às nossas necessidades." (Lenin, 1972a:236)

De acordo com Rainer Traub, sem ter perdido de vista os efeitos nocivos causados pela intensificação da exploração sobre o proletariado, a reavaliação realizada por Lenin sobre as técnicas tayloristas pode ser explicada por dois fatores. Por um lado a rápida desintegração da economia soviética. Em 1917, a produção industrial russa operava a $75 \%$ da capacidade produtiva do período pré-guerra, isto é, 1914. Já em 1918, devido às crises de produção agrícola e desarranjo da estrutura produtiva industrial causada pela tomada de poder dos trabalhadores, essa taxa se reduziu a 33\% dos índices préguerra. Com o avanço do Exército Branco em solo soviético, apoiado pelas potências capitalistas ocidentais e a intensificação da Guerra Civil, pouco restou ao Estado Soviético além de adotar como modelo de reorganização político-militar aquilo que ficou conhecido como "Comunismo de Guerra" (Traub, 1978: 85). Arthur Rosenberg ressalta como a profunda centralização 
das decisões políticos-administrativas acabou por levar ao esvaziamento do poder dos sovietes, fator indispensável para a própria sobrevivência do Estado Soviético frente ao ataque simultâneo em diversos fronts (Rosenberg, 1967 : 130). O reaparelhamento do nascente Exército Vermelho em pleno esforço de guerra acabou por tornar essencial um rápido incremento da capacidade produtiva russa. Como afirmou Traub, “(...) é difícil imaginar de que outra forma o Exército Vermelho, composto por milhões de soldados, poderia ser equipado para garantir a vitória final na guerra civil" (Traub, $1978: 86)$

Para Lenin, não se tratava de transplantar o taylorismo ipsis litteris para o solo soviético. O líder bolchevique entendia ser possível separar as técnicas e métodos de racionalização e gerenciamento do trabalho presentes na organização taylorista de seus fins, isto é, o incremento das taxas de lucros dos grandes capitalistas a partir da redução da força de trabalho empregada, que pressiona os salários para baixo, e aumento da mais-valia relativa por meio do incremento de produtividade - que leva à redução do preço mínimo a ser pago para a reprodução da força de trabalho. Ainda no mesmo texto, Lenin ressalta os objetivos a serem atingidos pela República Soviética por meio da aplicação de técnicas do taylorismo:

\begin{abstract}
“(...) o emprego do sistema Taylor, corretamente dirigido pelos próprios trabalhadores se esses são bastante conscientes, constituirá o meio mais seguro para uma sucessiva e enorme redução da jornada de trabalho obrigatória de toda a população trabalhadora, o meio mais seguro para que em um período bastante curto realizemos a tarefa que se pode expressar aproximadamente assim: seis horas diárias de trabalho físico para cada cidadão adulto e quatro horas de trabalho na administração do Estado?" (Lenin, 1972a:274)
\end{abstract}

Para Lenin os males produzidos pelas técnicas de gerenciamento laboral não eram intrínsecos ao taylorismo, mas antes decorrentes das limitações impostas pela própria anarquia de produção do sistema capitalista, que restringia tais técnicas ao espaço limitado da fábrica. Sob o controle social da produção, baseada na administração direta da atividade laboral pelos trabalhadores, seria possível não apenas simplificar o trabalho fabril e agrícola, mas reduzir a própria jornada de trabalho ao aumentar o output industrial por 
meio do incremento da capacidade produtiva. Liberto de jornadas de trabalho extenuantes, o trabalhador se dedicaria a administrar o Estado Soviético, participando diretamente de sua burocracia. De acordo com Angela Lazagna, a reconciliação cautelosa de Lenin com o taylorismo pressupõe um movimento dialético de superação das condições opressivas de existência do proletariado a partir da centralização da organização produtiva e aprofundamento da divisão social do trabalho. Esta ação possibilitaria o aumento da capacidade produtiva social e, como consequência, possibilitaria como síntese dialética a libertação desse mesmo operário através da redução da jornada de trabalho, incorporação de sua força de trabalho ao hábito administrativo do poder soviético e desenvolvimento da educação laboral. Estariam aqui assentadas as bases para o novo homem soviético (Lazagna, 2017:45).

O "taylorismo russo", marcado pelo enxerto e estudo de técnicas de padronização biomecânica e centralização decisória da divisão do trabalho, encontrou na organização social do trabalho e produção socialista a especificidade que o separaria de sua forma capitalista original e, sob um novo nome, tornar-se-ia objeto de um amplo debate que acabou por percorrer os anos formativos da União Soviética, encontrando em Alexei Gastev, poeta e operário, seu principal apologista: A Organização Científica do Trabalho (Nauchnaya Organizatsiya Truda (Научная Организация Труда) - NOT).

\subsection{Alexei Gastev e o Proletkult}

Alexei Kapitonovich Gastev nasceu na cidade de Suzdal, em 1878, no seio da Intelligentsia raskolnitchets. Assim como Lenin e Bogdánov, principais líderes bolcheviques no começo do século XX, Gastev era filho de um professor e uma costureira. Mudou-se ainda na juventude para Moscou onde matriculouse no Instituto de Professores de Moscou, do qual foi expulso em 1902 devido aos seus posicionamentos políticos. Filiado desde 1901 no POSDR, Gastev alinhou-se durante o cisma ocorrido no $2^{\circ}$ Congresso do Partido em 1903 às posições de Lenin, tornando-se um dos membros originais da facção bolchevique. Após exercer papel ativo na Revolução de 1905 Gastev acabou perseguido e exilado, vivendo por muitos anos em Paris, onde atuou como 
operário metalúrgico na Fábrica da Renault. Foi nesse local que Gastev se entusiasmou com as possibilidades estéticas e políticas do taylorismo (Wren \& Bedeian, $2004: 290)$.

Poeta avant-guarde, Gastev antecipou através de sua arte o culto ao aço, à fabrica e à destruição criadora das forjas, características fundantes das correntes artísticas do futurismo, simbolismo e maquinismo russos, conquistando o respeito de importantes poetas como Maiakovski, Khlebnikov e Aseev. Para Gastev a busca por formas artísticas cada vez mais radicais era obrigação revolucionária para todos os artistas envolvidos na construção de uma cultura operária. Herdeiro do radicalismo literário que marcou a Intelligentsia russa na segunda metade do século XIX, Gastev, como muitos de seus contemporâneos, acreditava firmemente no uso da arte como bússola estética que guiaria os trabalhadores em direção à consciência de classe e no papel pedagógico que deve ser exercido pelo artista socialista nessa empreitada. Diferentemente de Lenin, Gastev não apenas achava impossível desvincular as técnicas tayloristas do processo de brutalização do trabalhador, como via nesse mesmo processo possibilidades utópicas. Gastev viu na metalização da classe operária, na sua fusão com a máquina e à assimilação da cadência da fábrica como traço da persona, a imagem do futuro homem socialista. Sob o ritmo das máquinas, os milhões de operários "darão a luz a um homem que, em sofrimento, morte e destruição, através do esforço massivo do grande coletivo, subjugará o velho mundo, sanguinolento e cheio de culpa." (Gastev, 1913, apud Hellebust 1997 : 509).

O objetivo de Gastev era a criação de uma cultura operária que desse a luz ao grande coletivo a partir da amálgama entre o homem e a máquina, por meio da transmutação do primeiro na última. Esse processo seria acompanhado do surgimento de uma nova cultura: pragmática, estoica, cerebral e coletivista. Tal cultura emergiria de uma nova indústria, forjada na guerra, que resultaria na (e da) militarização dos trabalhadores em ordens hierárquicas rígidas. Gastev dividia os trabalhadores industriais em cinco tipos, baseado em critérios de habilidades, criatividade e formação: a primeira categoria era composta por trabalhadores mais habilidosos como maquinistas e torneiros, que acrescentavam ao seu trabalho toques de criatividade; na se- 
gunda categoria havia os trabalhadores de ampla capacidade e escopo técnico, os quais, mesmo que não contribuíssem criativamente com a produção, eram capazes de operar em uma ampla gama de funções; a terceira categoria era composta por trabalhadores cuja atividade era totalmente "estandardizada", desprovida de quaisquer elementos de criatividade e subjetividade; o quarto tipo abarcava todos os jovens trabalhadores e aprendizes, de conhecimento limitado, treinados em sistemas de educação técnica em massa; por fim, viriam os trabalhadores braçais, que realizavam tarefas pesadas para as quais não se exigiam quaisquer qualificações. Gastev dizia que, naquilo que concerne a produção fabril, só viriam a existir os trabalhadores do terceiro tipo, isto é, aqueles cujo trabalho careciam de subjetividade (Hellebust, 1997 :511).

A crescente maquinização da vida levaria ao desaparecimento tanto do trabalho pesado, quanto do trabalho criativo. Esse tipo de trabalhador, para Gastev, é a base na qual se deve pensar e construir a psicologia proletária e, consequentemente, sua cultura. Em artigo publicado em um dos diversos veículos do Proletkult, o jornal Cultura Proletária, de 1919, Gastev defendeu que a crescente mecanização e padronização dos operários:

“...produziria na psique proletária um forte senso de anonimato, permitindo a classificação de uma unidade operária em A, B, C ou 325, 0.075 e assim por diante. (...) A nossa frente repousa a possibilidade de haver, não apenas um trabalhador individual mecanizado, mas de um sistema de gerenciamento do trabalho mecanizado. Não uma pessoa, não uma autoridade, mas um tipo - ou grupo - que gerenciará outros tipos - ou grupos. Ou mesmo uma máquina, no sentido literal da palavra, irá gerenciar pessoas. Máquinas passarão de gerenciadas para gerentes. (...) Esse processo técnico de uniformidade crescente permearia todos os aspectos da existência do trabalhador: mesmo sua vida intima, incluindo seus valores estéticos, sexuais e intelectuais." (Gastev, 1919:36)

Esse novo homem soviético, preconizado pela racionalização científica do trabalho, se caracterizaria pela ausência de emoções; pela subsunção da persona no grande coletivo; no lançar-se em direção da morte e do sacrifício em favor das gerações futuras. De acordo com Gastev, a racionalização científica do trabalho: 
"...educa os músculos e nervos do proletariado, introjetando na psicologia proletária uma forma particular de prontidão, cheia de desconfiança para com quaisquer emoções humanas, confiando somente no instrumento, no aparato, na máquina." (Gastev, 1919:38)

Essa experiência política e estética - a metalização do corpo revolucionário - de acordo com Rolf Hellebust, é fruto de uma longa tradição utópica que atua como fator mediador entre a arte e a cultura russas: a transição entre o novo e o velho; entre a decadente autocracia do czar e o promissor futuro socialista; entre o homem supérfluo de Ivan Goncharov e o militante radical de Chernichevski; é também a transmutação da carne em metal (Hellebust, 1997:510) . Esse elemento simbólico, já presente na literatura radical do século XIX, acabou por ser reforçado pela profissionalização da vanguarda revolucionária, pressuposto definidor da facção bolchevique e causa fundamental para o cisma de 1903 (Hellebust, 1997:506). Tal homem é o advento de uma cultura que emergiria, por sua vez, da forja, da máquina e da mecanização de cada ato humano. Assim como na máquina, “...tudo é calculado e ajustado. Nós devemos realizar os mesmos cálculos com a máquina viva: o ser humano". Para Gastev, o caráter desumanizante do trabalho cientificamente organizado permite uma reavaliação do sofrimento, estendendo-o ao futuro, em direção à utopia. É no sofrimento voluntário do homem-massa que se encontram as bases do comunismo. O sacrifício tem como pré-requisito o livre-arbítrio, em que a escolha deliberada pelo sofrimento é o elemento que separa as massas trabalhadoras socialistas da condição alienada do trabalho característica do capitalismo. Esse sofrimento é acima de tudo coletivo, suportado estoicamente graças à natureza maquinal dos trabalhadores, em cujos ombros se alicerça o socialismo, assim como as vigas e cupolas suportam o peso de um edifício. Sua preocupação com o desenvolvimento de uma cultura autenticamente operária tornou Gastev uma figura central do Proletkult.

\footnotetext{
6 A representação metalizada do Revolucionário Profissional se estende desde anos 1850. Como breves exemplos podemos citar Eugeni Bazarov, revolucionário radical de "Pais e filhos" de Turgueniev ou Rakhmetov, protótipo do revolucionário profissional de Tchernichevski, descrito em "O que fazer?". A prática de metalização do revolucionário na arte será um motif frequente no realismo soviético, como podemos ver em "Kak zakalialas stal", de Nikolai Ostrovski (1934). A formação de uma Intelligentsia exclusivamente dedicada à revolução é, de acordo com Teodor Shanin, um desenvolvimento histórico dos revolucionários narodniks dos anos 1870 (Shanin, 1983:55).
} 
Logo após a Revolução de 1917, Gastev retorna do exílio e assume a direção do poderoso Sindicato dos Metalúrgicos de todas as Rússias. Gastev fundou, em 1920, por decreto lançado pelo Conselho Central dos Sindicatos de Todas as Rússias, o Instituto Central do Labor (Централныи Институт Труда: Centralnyi Institut Truda - CIT), instituição que serviria como ponta de lança para o estudo, ensino e implementação das técnicas de gerenciamento científico por todos os setores produtivos da nascente república soviética. No centro dos planos de estudo proposto por Gastev encontravamse tanto os estudos de cadência laboral desenvolvidos por Taylor quanto os estudos de movimentos laborais analisados por Frank Gilbreth. No entanto, diferentemente desses dois americanos, Gastev vislumbrou consequências sociais profundas no estudo e difusão da NOT. A partir do CIT, Gastev atuou diretamente sob a supervisão do GOSPLAN (Госсударственні̂и Комитет по Планированиу: Gossudarstvennîi Komitet po Planirovaniu - Comitê Estatal de Planejamento) e criou uma ampla rede de pesquisa, composta por mais de duzentos laboratórios distribuídos nos principais centros industriais da Rússia. Entre 1922 e 1927, mais de vinte jornais dedicados à NOT eram publicados pelo CIT. O trabalho de Gastev era, aparentemente, bastante apreciado nos principais círculos de poder soviéticos. A partir da solicitação de Gastev pela liberação de cinco milhões de rublos, Lenin encaminhou pessoalmente uma missiva para Ivan Skvortsov-Stepanov, Comissário das Finanças, solicitando que este "encontrasse os recursos necessários para o funcionamento de um Instituto tão vital quanto o CIT" (Lenin, 1922, apud Bailes 1977 :392). Um ano depois, em 1923, foi criado pelo Comissariado da Economia o Conselho Central para o Gerenciamento Científico, do qual Gastev ocupou a vice-presidência.

A ampla difusão de laboratórios e estudos do CIT e a aparente simpatia que o trabalho de Gastev gozava junto ao SOVNARKOM (Совет Народных Коммиссаров: Sovet Narodnykh Kommissarov - Conselho dos Comissários do Povo $)^{7}$ não impediram que seu trabalho fosse levado ao escrutínio do debate público. Importantes intelectuais apresentaram profundas críticas a

7 Conselho dos Comissários do Povo foi o órgão executivo máximo da então nascente República Socialista Federativa Soviética da Rússia, instituído pela Constituição soviética de 1918. 
NOT e reservas quanto às implicações políticas e sociais de sua implementação. A maior parte de seus detratores se encontrava entre estudiosos cujos trabalhos privilegiavam o o bem-estar dos trabalhadores em detrimento do aumento de produtividade. Um grupo de comunistas ligado ao Conselho de Gerenciamento Científico (Sovnot), órgão ligado ao Comissariado de Inspeção de Trabalhadores e Camponeses (Rabkrin) (Народныи Коммиссариат Pабоче: Narodnyi Kommissariat Raboche), tornou-se responsável, por deliberação do XII Congresso do Partido Comunista, a organizar a burocracia do governo Soviético. Gastev, por não fazer parte do Partido, acabou excluído. As atividades organizadas pelo CIT foram duramente criticadas na primeira conferência do Sovnot, realizada em Janeiro de 1923. Por meio de resoluções, diversas pesquisas do CIT foram rejeitadas e os dirigentes do conselho defenderam a criação de um sistema de racionalização do trabalho baseado no desenvolvimento agressivo dos meios de produção, em detrimento da mecanização ostensiva dos movimentos biomecânicos dos trabalhadores russos.

Entre os principais opositores de Gastev figuravam um dissidente do corpo técnico do CIT, o diretor do Instituto do Labor de Kazan Ivan Burdiansky, e Yakolev Shatunovski. Ambos teciam profundas críticas ao que consideravam uma visão estreita do gerenciamento científico do trabalho tal como era exposta por Gastev. Para eles Gastev era presunçoso ao superlativar o papel do CIT no desenvolvimento do GOSPLAN е do GOELRO (Госсударственні̂я Комиссия по Електрификассии России: Gossudarstvennîya Komissiya po Elektrifikassii Rossii - Comissão do Estado para Eletrificação da Rússia), o grande plano de eletrificação da Rússia. Sua predileção ao primitivismo da biomecânica era absurda ao ignorar os avanços tecnológicos que já aconteciam em solo soviético. Essas críticas orbitavam aquilo que consideravam a falha fundamental de Gastev: sua insensibilidade para com a proteção dos trabalhadores em ambiente de trabalho. Shatunovski questionou em artigo publicado na revista "Novidade Vermelha" se era realmente necessário "[...]falar sobre o significado da proteção do trabalho em um país proletário? É possível que uma pessoa minimamente alfabetizada em questões de organização do trabalho não saiba que as condições básicas de produtividade é um ambiente 
iluminado, limpo, espaçoso e bem-ventilado?" (Shatunovsky, 1922, apud Bailes $1977: 387)$.

Gastev, por sua vez, fazia pouco dessas críticas. Para o diretor do CIT, a Rússia já contava com um número suficiente de psicólogos e filósofos e apontava seus argumentos contra o caráter livresco de seus opositores, destituídos de inventividade e energia. Gastev defendia a necessidade de preparar a indústria russa para saltos inéditos de produtividade e isso somente seria possível com: "...preparo infinito e paciência, o poder de observação e a habilidade de analisar e mensurar tempo e espaço" (Gastev, 1923, apud Bailes 1977 :394). Gastev também respondeu aos ataques por meio do apoio de importantes figuras do Partido ao seu trabalho. Para tanto, apresentou em resposta às críticas de Shatunovski um discurso feito em outubro de 1923 por Bukharin direcionado à juventude comunista em que defendia a reforma da psicologia humana; a fusão entre a teoria marxista e a praticalidade e "know-how" americanos; o fim da hegemonia das humanidades como núcleo formador do ensino em favor do ensino técnico e prático; e o condicionamento do corpo para o trabalho produtivo. Além de Bukharin, Gastev contou com o apoio de Zinoviev e Andreev, secretário do Comitê Central do Partido, que publicaram no começo de 1924 uma série de artigos no Pravda e Izvestia tecendo loas ao importante trabalho desenvolvido pelo CIT (Gastev, 1922, apud Bailes $1977: 398)$.

De acordo com Traub (1978:87), a principal reação às posições de Gastev sobre os objetivos do sistema educacional soviético partiram do NARKOMPROS (Народныи комиссариат просвещения: Narodnyi komissariat prosveshcheniya - Comissariado do Povo de Educação), mais especificamente de seu comissário, Anatol Lunacharski. Em artigo publicado no jornal Isvestia, Lunacharski criticou não apenas a obsessão de Gastev com as máquinas mas também seu fascínio pelo americanismo (Lunacharski, 1923). Ainda que apoie o aumento de produtividade propugnado pelo CIT de Gastev, Lunacharski aponta que o operário russo não é o operário americano e que esse - dominado pela máquina - não tem a "oportunidade de pensar o seu ser" (Lunacharski, 1923 : 2). De acordo com McClelland (1971), essa crítica se estendeu para a concepção tecnocrática e centralizada de formação proposta por Gastev, em 
contraposição à ênfase que o NARKOMPROS dedicava em seus anos iniciais à educação descentralizada, local e e de formação integral. Subjacente a esse debate encontra-se o próprio papel a ser exercido pelo Proletkult, principal projeto de Lunacharski e Bogdánov: a elevação por meio da educação integral do nível de consciência dos trabalhadores. Esse projeto se chocava diretamente com os objetivos de Gastev, ao privilegiar o desenvolvimento amplo da consciência de classe em detrimento do desenvolvimento de uma economia industrializada avançada (McClelland, 1971: 821).

Esses debates, ocorridos nos anos formativos da Rússia Soviética e que atravessam os anos da Guerra Civil, nos mostram que a imbricação entre a organização da produção, o gerenciamento do trabalho e o desenvolvimento de uma nova cultura, adaptada às necessidades da revolução, era um "nó górdio" que concentrou a atenção de importantes nomes da Intelligentsia russa, tanto entre o comissariado do nascente Estado soviético quanto entre as fileiras de intelectuais não-bolcheviques. Bogdánov participou diretamente desse debate nos anos iniciais do Proletkult, retirando-se depois que Lunacharski atendeu a Lenin em submeter o Proletkult ao controle do Partido Comunista. A despeito de seu afastamento, as críticas de Bogdánov direcionadas a NOT apresentam considerável coerência quando cotejadas diacronicamente com seus trabalhos anteriores. É no momento em que tratamos a organização do trabalho em sua relação com a dimensão cultural que salta em "Estrela Vermelha" o reflexo negativo no qual se funda sua crítica.

\subsection{Produção e Estado em "Estrela Vermelha"}

As posições de Bogdánov acerca do taylorismo foram primeiramente publicadas em 1913 no jornal "Priboi" em um artigo intitulado "Mezhdu tchelovekom i machinuiu: a sisteme taylora" (Entre o Homem e a Máquina: Sobre o sistema Taylor). Esse artigo foi posteriormente republicado no jornal "Proletskaya Kultura" em 1919, sem alterações. Dado o contexto de sua republicação, podemos supor que possivelmente essa se deu como resposta à influência 
de Gastev junto aos órgãos do Proletkult, ainda que não haja dados que confirmem tal suposição.

É interessante notar, mesmo que de passagem, a forma como os argumentos de Bogdánov e Lenin acerca do sistema taylorista dialogam diacronicamente. Enquanto Lenin apresentava no começo da década uma posição claramente hostil ao sistema taylorista, Bogdánov fazia concessões críticas. Esse reconhecia o sucesso do sistema taylorista ao promover um enorme aumento de produtividade: "várias dezenas de pessoas produzem por meio do trabalho organizado o equivalente a centenas de artesãos" (Bogdanov, 1913). Além disso, Bogdánov admite a necessidade em se estudar "cientificamente" os mecanismos biomecânicos de labor, de forma que "se eliminem movimentos desnecessários e se obtenha uma maior correspondência entre os trabalhadores e suas condições de trabalho". Esses estudos eram necessários uma vez que seus resultados trariam vantagens à segurança do trabalhador ao mesmo tempo em que sua produtividade seria elevada, beneficiando toda a sociedade.

Essa posição de Bogdánov se assemelha à posição de Lenin já expressa em 1919. Há elementos positivos a serem extraídos do sistema taylorista. No entanto, a partir dessas concessões, Bogdánov elabora uma crítica ferrenha às consequências sociais do gerenciamento taylorista. De acordo com ele, A produção capitalista industrial leva a uma divisão técnica do trabalho cada vez mais aguda, que acaba por reificar o trabalhador, transformando-o em máquina. Esse processo, no entanto, encontra-se em relação dialética com o próprio desenvolvimento tecnológico: a partir do momento que um homem é "obrigado a repetir 48.000 vezes movimentos simples e uniformes, esse homem é uma máquina. No entanto, nesse caso, já é relativamente fácil substituí-lo por uma máquina" (Bogdanov, 1913).

Para Bogdánov, o taylorismo realiza um "truque de salão": sua implementação de fato aumenta o output produtivo. No entanto isso não é feito através do aumento de produtividade, mas sim pelo aumento da intensidade de exploração. Bogdánov se usa da construção civil para exemplificar seu ponto:

"Se era possivel reduzir dezoito movimentos para cinco na alvenaria, é claro que isso não significa que o trabalho foi facilitado na mesma 
extensão: apenas os principais movimentos que exigem mais esforço permanecem e eles mudam para que exijam mais energia do que antes, e movimentos mais lentos são substituídos por movimentos mais rápidos. (...) Se os trabalhadores depositaram três vezes mais tijolos em cada hora, então, obviamente, a principal razão é simplesmente um aumento de desperdício de força, aumento da tensão do trabalho." (Bogdanov, 1913:np)

Bogdánov explica com esse exemplo a prestidigitação de Taylor: o aumento de produtividade do sistema taylorista depende menos da organização científica do trabalho e mais da seleção de trabalhadores "excelentes" e capazes de resistir a níveis altíssimos de exploração em detrimento dos trabalhadores que gravitam em torno da capacidade média social de trabalho. Esses são descartados, sacrificados em favor do aumento da mais-valia absoluta extraída dos trabalhadores maquinizados. Esses poucos trabalhadores, assim como ocorrem com os bens de capital, serão gastos em velocidade proporcional ao trabalho deles extraídos. Além disso, o sistema de pagamento por peça (piece-rate system) agravaria ainda mais a competição entre os trabalhadores, em favor daquilo que Taylor considerou um dos fundamentos de seu sistema: a harmonia entre o gerenciamento e o trabalho; super-exploração; hiper-reificação; desgaste prematuro; e obsolescência do trabalhador médio. Esses seriam os fatores que explicam o aumento de produtividade resultante do sistema taylorista (Bogdanov, 1913).

Para Bogdánov, a partir de um ponto de vista organizacional, o sistema taylorista é contraproducente à própria maquinofatura capitalista. A redução da força de trabalho a partir da intensificação da atividade laboral acaba por exigir no lugar dos trabalhadores "médios" a contratação de supervisores e colaboradores, aumentando a dependência do Capital da parcela nãoprodutiva do capital variável, isto é, da fração de trabalhadores que atuam na otimização do processo de realização do Capital na sua forma-trabalho, sem produzir diretamente mais-valor. Essa categoria de trabalhadores de colarinho-branco - engenheiros, supervisores, estatísticos i.e. "a Intelligentsia Técnica" - exerce papel central no sistema de pensamento de Bogdánov. No entanto, sob a hegemonia das relações de produção capitalistas, acabam por expressar no chão-da-fábrica as relações de exploração impostas sobre o 
trabalho pelo Capital.

Diferentemente de Gastev, Bogdánov não acredita possível a construção de uma visão de mundo operária a partir da intensificação do processo de alienação do trabalho. A maquinofatura é, para ele assim como o é para Gastev, o fundamento organizativo do trabalho social do qual tal visão emergirá. No entanto, para Bogdánov essa não exige coisificação do trabalhador. Ao contrário, a maquinofatura necessita da inteligência do trabalhador: "Um homem de verdade é necessário acima da máquina e não uma máquina viva de Taylor." (Bogdanov, 1913:np) Ainda que produza temporariamente desemprego, Bogdánov conclui seu artigo afirmando que esse fenômeno

\footnotetext{
“(...) é muito menos prejudicial e não é tão infrutífero quanto o desemprego criado pelo treinamento brutal e desgaste prematuro de trabalhadores empregados. Cada passo adiante na maquinofatura eleva a sociedade a um nivel organizacional mais alto, prepara e aproxima o seu futuro melhor." (Bogdanov, 1913)
}

Assim como Gastev e diversos futuristas que lhe eram contemporâneos, Bogdánov era um entusiasta das possibilidades utópicas da máquina. Assim também como Lenin, ele compreendia haver uma relação íntima entre as formas supraestruturais e as práticas sociais de reprodutibilidade da vida. Por outro lado, diferentemente de Gastev, Bogdánov não via na indiferenciação entre o homem e a máquina uma rota possível para o socialismo. Afastado da disputa política, seu posicionamento em relação ao gerenciamento científico do trabalho manteve-se em acordo com a leitura que fazia da obra marxiana e que serviu de alicerce para sua própria obra: a superação do fetichismo, isto é, das condicionalidades historicamente dadas aos homens através de relações de produção cuja reprodução opera de forma automática (Marx, 2013 :274). Bogdánov entendia que não haveria rota para o socialismo que não passasse pelo domínio consciente dos trabalhadores sobre a produção, sem que os trabalhadores se tornassem, através da revolução, mestres da maquinofatura.

A crítica de Bogdánov aqui exposta deve ser compreendida de acordo com o papel que reservou à tecnologia em seu sistema de pensamento. Como vimos no segundo capítulo (p. 47), Bogdánov decompõe a atividade social do Labor 
em dois níveis dialeticamente imbricados a saber: o nível tecnológico e o nível organizacional. Tal decomposição por sua vez acabou por trazer em sua obra variações sensíveis em relação à economia política marxiana, adequando-a à sua abordagem sistêmica e funcional. Para Bogdánov uma sociedade, assim como qualquer sistema, é composta de agregados de elementos interrelacionados a partir de bases funcionais por meio das quais se estabelecem relações de produção. A reprodução desse sistema se expressa na produção, i.e. nos frutos decorrentes do esforço empreendido socialmente contra o reino da resistência - a natureza - que garantem seu desenvolvimento através das gerações e sobrevivência frente às pressões externas. Em sua obra "Curso Curto de Economia Política" (Bogdanov, 1932), Bogdánov argumentou que a produção por sua vez era composta por três níveis distintos: uma dimensão técnica, que envolve o confronto do homem contra a natureza e os métodos empregados nesse confronto (Bogdanov, 1932:6); uma dimensão social que se refere às relações entre as pessoas estabelecidas no processo de produção (Bogdanov, 1932:7-8); e uma dimensão ideológica, que encarna o corpo de ideias, normas, costumes e saberes necessários para organizar a produção (Bogdanov, 1932:9).

Bogdánov defendeu que, ainda que possam ser vistas como categorias distintas e analisadas individualmente, cada nível que compõe o processo produtivo encontra-se profundamente imbricado com os demais e nenhuma análise que não dê conta da totalidade dessas relações seria capaz de compreendê-las separadamente. Isso não significa, no entanto, que Bogdánov as tome de forma tautológica. Para ele, a interação entre esses fatores encontrava-se delineada por uma hierarquia estabelecida entre essas atividades:

"O desenvolvimento primário é definido naquela esfera na qual o homem está em contato direto com a natureza - na esfera das relações técnicas do homem com a natureza, na esfera das forças produtivas. Relações de Produção são formadas com base nessas relações técnicas entre o homem e a natureza e, com base em ambas, ideias, normas e ideologia são formadas. Consequentemente, o fator primário é a técnica, o qual define a economia e, posteriormente a ideologia. Essa é a Lei do Desenvolvimento." (Bogdánov, 1923, apud Sochor 1988:57)

Sochor atenta para a distinção que Bogdánov faz entre meios de produção 
- a forma material das ferramentas necessárias para a reprodução social - e tecnologia, que inclui não apenas os meios de produção mas também as habilidades e conhecimentos técnicos necessários ao trabalho (Sochor, 1988:60). Em artigo intitulado "Psicologia Social", Bogdánov chegou mesmo a evitar o uso do termo "forças produtivas" em favor do termo "técnica" em articulação com as relações de produção. A tecnologia i.e. a dimensão tecnocientífica que atua diretamente na reprodução sistêmica da sociabilidade, gesta as formas sociais e ideológicas por meio da práxis laboral as quais por sua vez produzem transformações sistêmicas e reforçam o esforço de labor expresso na forma objetiva - portanto social - da tecnologia (Bogdánov, 1911, apud Sochor 1988: 82).

A primazia da esfera técnica da produção sobre as esferas econômica e ideológica é um fundamento importante no pensamento de Bogdánov e se refletirá na forma como ele tratou os debates acerca das classes sociais e da divisão social do trabalho. Em "Estrela Vermelha" Bogdánov dedica uma parte considerável da obra para descrever diversas maravilhas tecnológicas presentes no cotidiano dos marcianos. Tal esforço não parece estranho se o entendermos a partir de duas chaves interpretativas: o papel que aparatos científicos exerceram na Ficção Científica Moderna; e a recepção para o qual Bogdánov dirige a sua obra.

Muitas obras de FC da modernidade caracterizam-se pela reificação da ciência através do desenvolvimento de um "dispositivo narrativo", isto é, um mecanismo, princípio ou postulado científico cuja operação condiciona o desenvolvimento da narrativa. A título de exemplo podemos citar rapidamente o submarino de Nemo em "20.000 léguas submarinas"; a máquina do tempo em "O Viajante do Tempo"; e já no século XX, as três leis da Robótica de "Eu Robô" ou o monólito negro de "2001: uma Odisseia no Espaço". O uso generalizado de dispositivos narrativos é explicado por Darko Suvin devido à plausibilidade potencial que existe na extrapolação da ciência enquanto paradigma constitutivo de sentidos e cujos objetos materiais encontram-se presentes no cotidiano dos grupos sociais e acabam constituindo-se como artefatos ideológicos que expressam uma ciência fetichizada, estranha aos homens e que muitas vezes acaba imbuída por caracteres prometeicos ou 
apocalípticos. Tais caracteres expressam-se historicamente na FC através de uma pletora de obras utópicas ou distópicas, cujo denominador comum é uma marcha inexorável em direção ao futuro, seja esse libertador ou opressivo. Seu caráter fetichista faz valer o sentido de falsa consciência, pois oculta a ciência como um processo organizativo do conhecimento que opera nos limites da totalidade e que é resultado da ação humana; ao contrário, a ciência faz "dançar a mesa", carregando seus artefatos de irracionalidade. Essa irracionalidade, assentada sobre a plausibilidade sensível do fetiche, é aquilo que permite o "estranhamento cognitivo", o "Novum" característico da FC (Suvin, $1979: 78$ ).

"Estrela Vermelha", assim como a maioria das obras de FC que lhe é contemporânea, apresenta uma grande variedade de dispositivos e tecnologias. Esses recursos são utilizados pelo autor para contrastar a assimetria que existe entre o desenvolvimento tecnológico da Terra e de Marte em favor desse último. Além disso, como citamos anteriormente, "Estrela Vermelha" é uma obra de cunho pedagógico, cujo público-alvo é composto pelas classes trabalhadoras urbanas. Bogdánov tentou apresentar Marte como uma possibilidade real de futuro, cujas conquistas seriam compartilhadas por todos. O socialismo de Marte é uma promessa de futuro para os povos oprimidos da Terra. Essa posição é marcada nas páginas iniciais de "Estrela Vermelha" quando Leonid externa para Netti seus receios ao observar a Terra se afastando pela cupola da nave que os levará para Marte.

"Enquanto contemplava, senti-me triste que já não podia ver minha terra nativa, onde havia tanta vida, luta e sofrimento, onde somente ontem eu ainda me encontrava nas fileiras de meus camaradas e onde agora alguém já ocupou meu lugar. Dúvida começou a ser erguer de meu ser. Lá sangue está sendo derramado', disse. 'E ainda assim aqui estou eu, um revolucionário de ontem, no papel de um calmo observador." (Bogdanov, 1984 [1908]:47)

O acesso a maravilhas tecnológicas preenchem a obra. Naves voadoras individuais que chegam a atingir 240 quilômetros por Hora e são movidas por "menos-matéria", um elemento sintético que produz uma força antigravitacional (Bogdanov, 1984 [1908] : 28); o uso de cromoterapia para produzir determinadas reações de cunho terapêuticos (Bogdanov, 1984 [1908] : 33, 
60); naves interplanetárias denominadas "Eterófonos" impulsionadas por reatores de energia nuclear a partir da catalização do processo de decaimento de núcleos instáveis (Bogdanov, 1984 [1908] : 37); aparelhos que transcrevem sons em texto escrito (Bogdanov, 1984 [1908] :61); aparelhos telefônicos residenciais com múltiplos canais que transmitem a imagem dos conferencistas (Bogdanov, 1984 [1908]: 61).

Dentre essas diversas maravilhas tecnológicas, nos chama a atenção aquelas que se relacionam com as questões de saúde. Bogdánov dedica a essas mais tempo em sua descrição, em parte por sua formação médica, em parte por representarem projetos científicos pessoais. Em nenhum momento da obra, Bogdánov nos fornece a expectativa de vida dos marcianos. Ao contrário, em alguns momentos somos levados a entender que os marcianos aboliram a morte por envelhecimento, atingindo tecnicamente a imortalidade. Em visita a Netti, Leonid é levado a conhecer um hospital marciano e questiona a médica a respeito da longevidade dos marcianos. Netti lhe explica que tal longevidade é fruto de um método de rejuvenescimento baseado na transfusão de sangue. Por meio da médica, Bogdánov expõe mais uma vez seus princípios tektológicos em status nascendi:

"De forma a elevar a viabilidade de células ou organismos, a natureza constantemente suplementa um indivíduo com outro. Assim, quando a vitalidade de seres unicelulares é interrompida por uma falta de variação no ambiente, eles se fundem, dois tornando-se um. Essa é a única maneira de que eles encontram para recuperar a imortalidade de seus protoplasmas, isto é, a habilidade de procriar. (...) Você está familiarizado com as transfusões sanguineas e a forma com a qual elas transmitem elementos de vitalidade de um ser para o outro. Elas podem aumentar a resistência para diferentes doenças. Nós vamos além e realizamos transfusões de sangue mútuas entre seres humanos, em que cada indivíduo recebe de outro um número de elementos, os quais podem elevar sua expectativa de vida." (Bogdanov, 1984 [1908] : 85)

Por conta dos objetivos propostos, nos limitaremos nesse trabalho às atividades de Bogdánov enquanto filósofo da ciência e de seu esforço na construção de uma ciência proletária. No entanto, não podemos nos furtar de lembrar que Bogdánov também foi um cientista experimental no campo da hematologia, área que sempre o fascinou e para a qual se dedicou nos 
anos finais de sua vida como Diretor do Instituto de Transfusão de Sangue de Moscou, o primeiro instituto dedicado às pesquisas de transfusão de sangue no mundo, fundado em 1926 (Krementsov, 2011 : 42). Enquanto, sob a causalidade do labor, a troca de sangue é eivada de princípios simbióticos e cooperativos, fundamentada na sobrevivência do grande coletivo a partir da revitalização de seus elementos, sob a lógica da causalidade burguesa predomina na obra de Bogdánov uma relação parasitária, expressa na forma do vampiro. Esse extrai do sangue dos vivos sua vitalidade, em detrimento da sobrevivência do coletivo. Essa imagem é nítida na descrição com a qual Bogdánov inicia sua obra: ao descrever a resistência da autocracia russa aos eventos de 1905, Leonid usa as seguintes palavras:

"Ninguém havia imaginado tamanha tenacidade demonstrada pelas mãos ossudas do cadáver que há muito esmagava e ainda esmaga os vivos em seu abraço compulsivo." (Bogdanov, 1984 [1908] :24)

Como vimos anteriormente, o energitismo de Ostwald exerceu considerável influência sobre o princípio de equilíbrio dinâmico de Bogdánov, fundamental por sua vez em sua teoria de sistemas. Todo sistema busca manter-se em equilíbrio com seu meio através de mecanismos bi-regulatórios; se a soma das atividades (fluxos de energia) dos elementos de um dado sistema supera as resistências em relação ao meio, esse sistema cresce, se desenvolve, se complexibiliza, torna-se mais organizado. O princípio de equilíbrio dinâmico encontra-se expresso em diversos trechos de "Estrela Vermelha". Por meio da atividade social - o confronto com a natureza - os marcianos buscam restabelecer através dos canais o equilíbrio ambiental de um planeta em fase de desertificação; através da troca camarada de sangue, estabelecese o equilíbrio fisiológico de seus cidadãos. Através da central estatística, estabelece-se o equilíbrio sobre a oferta e demanda de trabalho e mercadorias. Em consonância com o fundamento universal de sua ciência organizacional a ser exposta anos depois, "Estrela Vemelha" já traz em sua narrativa as formas iniciais de tal princípio, cujo modelo pode ser aplicado às mais diversas esferas da atividade humana.

De acordo com Zenovia Sochor, Bogdánov definiu as relações de produção por meio de duas categorias organizacionais: as relações de produção 
baseadas na cooperação entre indivíduos, de natureza simbiótica, em que a soma dos esforços beneficiam cada complexo de elementos; e as relações de produção baseadas na apropriação, de natureza parasitária, cujos complexos de elementos centralizam a energia do sistema em detrimento da soma total de atividade (Sochor, 1988:61). Bogdánov utilizou-se da figura mítica do Vampiro como arquétipo das relações de produção parasíticas predominantes sob o capitalismo. O vampiro não é tão somente a representação do "outro" ideológico. ele é a representação de um sistema de elementos ideológicos que ocultam as relações de produção apropriativas. Em ensaio intitulado " $O$ Grande Vampiro de nossos tempos", publicado em 1910, Bogdánov se utilizou da metáfora do vampiro para se referir às classes reacionárias:

"As lendas sobre vampiros e mortos-vivos figurativamente expressam um fenômeno social generalizado - aqueles casos nos quais aquilo que é obsoleto, indesejável e socialmente estéril diminui a força daquilo que é progressivo, criativo e socialmente útil. E de forma alguma são "vampiros" somente pessoas; eles podem ser grupos, classes, instituições, ideias e princípios" (Bogdánov, 1910, apud Greenfield 2006 :628)

A troca camarada de sangue expressa em "Estrela Vermelha" apresenta tal relação em seu sentido positivo, isto é, enquanto acréscimo de energia ao sistema. Vampirismo ao contrário representa o conflito entre o novo e o velho, entre o vivo e o que já viveu. Seu ato não eleva a soma de elementos evolutivos, não insta a longevidade do sistema. Ao contrário, priva o mundo daquilo que é novo e original, reduz sua forma possível, emperra seu desenvolvimento (Greenfield, 2006 :629). Para Bogdánov, cada elemento deve contribuir mais do que obtém de seu sistema. Essa é a base de seu coletivismo. A atuação harmônica dos elementos acaba produzindo os mecanismos reguladores que atuam sempre em direção ao equilíbrio, modulando as disparidades e reduzindo o impacto de elementos disruptivos. Esse processo é a pedra angular do socialismo marciano e organiza todos os aspectos da vida social e produtiva.

Bogdánov fez do princípio do equilíbrio dinâmico o fundamento da sociedade marciana. Diferentemente do que afirma Jensen, não é a menos-matéria ou a busca por proteínas sintéticas que realizam em "Estrela Vermelha" o 
papel de mecanismo narrativo (Jensen, 1982:52). A sociedade marciana ciberneticamente regulada - é o próprio mecanismo narrativo da trama, pois é através dela que Bogdánov apresenta não apenas sua teoria empiriomonista, mas os futuros elementos de sua ciência organizacional em estado embrionário.

Bogdánov dedicou esforço considerável em descrever o sistema produtivo marciano. No capítulo "A Fábrica", após conhecer as máquinas de uma indústria metalúrgica, Leonid questiona Menni sobre a organização da produção. Esse, sem lhe responder, o leva a um pequeno edifício localizado no centro da construção. Em seu interior Leonid observa paredes negras cobertas com colunas de dados estatísticos de produção. Leonid passa então a descrever seu conteúdo:

"'A indústria de máquinas apresenta excedente de 968.757 horashomem diárias, das quais 11.325 horas são de trabalho especializado. O excedente dessa fábrica é de 753 horas, das quais 29 horas são de trabalho especializado'.

'Não há falta de trabalho nas seguintes indústrias: agricultura, química, escavações, mineração..' e assim segue em uma longa lista alfabética de vários setores da indústria.'

Na segunda tabela está escrito:

'A indústria de vestuário apresenta escassez de 392.685 horas-homem diárias, da qual 21.380 horas requerem técnicos com experiência em máquinas especializadas e 7.852 horas requerem especialistas em organização'.

'A indústria de sapatos apresenta escassez de 79.360 horas, das quais...'

E assim segue.

'O Instituto de Estatística - 3.078...' E assim segue." (Bogdanov, 1984 [1908]:65)

Menni então explica para Leonid que as tabelas têm a intenção de afetar a distribuição de trabalho em escala global. As tabelas que demonstram demanda por trabalho são descritas de forma mais precisa, de forma a garantir aos trabalhadores informações precisas sobre onde seu trabalho é mais necessário.

Enquanto ouve a explicação de Menni, Leonid percebe que os dados das tabelas se alteram. Ao questionar seu guia, Menni explica que:

"Os dados são alterados a cada hora. No curso de uma hora, vários milhares de trabalhadores anunciam que querem trocar de trabalhos. 
O Aparato Central Estatístico toma notas constantes disso, transmitindo os dados de hora em hora para todos os ramos da indústria." (Bogdanov, 1984 [1908]:66)

Em seguida Menni explica o funcionamento do Instituto de Estatística:

"O Instituto de Estatística tem agências em todos os lugares, as quais acompanham a entrada e saída de bens dos estoques e monitoram a produtividade de todas as empresas, bem como a mudança em suas forças de trabalho. Daquela forma é possivel calcular o que e em qual quantidade deve ser produzido em um período de tempo dado e o número de homem-horas necessário para a tarefa. O Instituto então computa a diferença entre as situações existente e desejada para cada área vocacional e comunica o resultado a todos os locais de empregamento. Equilíbrio é logo atingido por um fluxo de voluntários." (Bogdanov, 1984 [1908]:66)

Categorizar historicamente o modelo econômico que propõe Bogdánov se mostrou uma tarefa complexa. Na tradição literária utópica não há, no escopo diacrônico desse trabalho, quaisquer esforços em descrever o sistema produtivo que se comparem àquele que Bogdánov dedica em "Estrela Vermelha" . Mesmo obras como "Looking Backwards" (1888) de Edward Bellamy e "News from Nowhere" (1890) de William Morris apresentam sistemas econômicos cujo cálculo de demanda ainda é determinado pelo valor de troca das mercadorias e cuja produção não se afasta do sistema de estoque em larga escala, característico do paradigma de produção fabril da época. Nesse sentido, Tanto Bellamy quanto Morris encontram-se inseridos na tradição econômica do socialismo utópico do século XIX, cuja crítica e projeto viam-se ainda limitadas por um capitalismo industrial que se encontrava em processo de consolidação. Essa tradição, representada principalmente pelo socialismo francês de Pierre Joseph Proudhon, não enxergava a relação contraditória entre valor de troca e valor e por isso propunha a abolição da propriedade privada capitalista em favor da propriedade cooperativa da produção, mantendo-se as relações de produção características do capitalismo, expressas em sua forma mais reluzente: a forma-dinheiro. A partir da dissolução do Estado, a produção acabaria organizada a partir de Federações produtivas, de caráter mais-ou-menos permanente, que trocariam seus produtos em um sistema 
de mercado. David McNally observou que essa concepção - a existência de mercados como sistema distributivo em uma economia socialista - comum a diversos socialistas na primeira metade do século XIX, acabava por desconsiderar que a demanda por mercadorias em uma economia de mercado está imbricada com a existência de um mercado de força-de-trabalho, origem da desigualdades e exploração. Sem esse, não é possível a universalização da troca de mercadorias. Ao aceitar as relações de mercado (mercadoria, preço e trabalho assalariado), tais socialistas acabam por aceitar as consequências dessas relações (McNally, 1993 : 169).

Em "A Miséria da Filosofia" Marx atacou duramente as posições de Proudhon, fazendo dessa um "estudo de caso". Em sua obra, Marx demonstra que o posicionamento de Proudhon a favor de uma economia de mercado convalidava a própria dimensão fetichista do Capital, que oculta através da igualdade de troca, as relações desiguais que marcam a exploração. A realização da troca a partir de um equivalente universal só é possível pela negação das particularidades do trabalho social contido na mercadoria. O tempo de trabalho socialmente necessário - valor - é negado na relação de mercado por uma medida exterior cuja expressão - a forma dinheiro - é a negação do valor que se constitui na materialidade da mercadoria: "sobre a base da produção mercantil, o trabalho só se torna trabalho social pela alienação universal dos trabalhos individuais" (Marx, 1985 : 180). Para Marx nos parece claro que sua concepção de socialismo implica na desfetichização da vida econômica, i.e. na libertação do ser humano das condicionalidades determinadas por leis econômicas impessoais. Isso passa pela produção consciente, determinada pelos valores de uso produzidos pelo trabalho. Essa concepção nega ontologicamente qualquer cálculo econômico determinado pelas forças de mercado e aponta para uma sociedade cuja reprodução opera sob valores diferentes daqueles determinados pela troca de mercadorias, propriedade privada dos meios de produção trabalho assalariado. O pensamento marxiano é essencialmente hostil a quaisquer formas de distribuição que operem sob a lógica irracional do valor de troca (McNally, 1993: 169).

O sistema produtivo marciano parece se encontrar em acordo com a concepção marxiana. Inexiste em Marte um equivalente universal. A demanda 
de trabalho não se expressa por meio da forma-salário, mas através do tempode-trabalho socialmente necessário para a produção. A sociedade marciana é amonetária e o consumo por sua vez determina a demanda. Menni explica que "todos pegam o que precisarem na quantidade que desejarem" (Bogdanov, 1984 [1908] : 66). Com isso Bogdánov sintetiza em Marte um dos raros momentos em que Marx se dispôs a fazer um exercício de imaginação sobre o futuro comunista:

"quando, juntamente com o desenvolvimento multifacetado dos indivíduos, suas forças produtivas também tiverem crescido e todas as fontes da riqueza coletiva jorrarem em abundância, apenas então o estreito horizonte jurídico burguês poderá ser plenamente superado e a sociedade poderá escrever em sua bandeira: de cada um segundo suas capacidades, a cada um segundo suas necessidades!" (Marx, 2012:33)

Leonid questiona como é possível que o sistema funcione sem um documento que ateste que uma certa quantidade de trabalho fora realizada. Menni lhe explica que tais questões são irrelevantes uma vez que toda a força de trabalho é voluntária. Assim como Marx, Bogdánov explica por meio de seu personagem que o trabalho - em sua condição desalienada - é "uma necessidade natural para os membros maduros de nossa sociedade” (Bogdanov, 1984 [1908] : 66). Como citamos anteriormente, Bogdánov enxerga na alienação o ponto central da crítica marxiana. A sociedade marciana é uma sociedade de pós-escassez, cujo trabalho opera enquanto essência antropológica.

Em tal sociedade, Bogdánov não vê razão para quaisquer controle sobre consumo. Leonid, ainda não convencido, questiona se há grandes flutuações nas compilações estatísticas devido à ausência de barreiras para o consumo. Menni explica que os desvios em nível individual são negligenciáveis:

"Um simples indivíduo pode de repente comer duas a três vezes mais do que seria sua porção normal de determinada comida ou decidir mudar dez peças de roupa em dez dias, mas uma sociedade de bilhões de pessoas não está sujeita a tais flutuações. Em uma população daquele tamanho desvios em qualquer direção são neutralizados, e as médias mudam muito lentamente e dentro da mais estrita continuidade." (Bogdanov, 1984 [1908] :66) 
No sistema marciano, os principais fatores que produzem alterações significativas dos dados estatísticos são aquelas referentes a alterações no meio e transformações tecnológicas. Menni explica que tais alterações acabam por necessitar de transferências de força de trabalho entre diferentes setores. Novas máquinas requerem força de trabalho nos setores em que essa é implementada, no setor de construção de maquinário e na produção de materiais para ambos os setores. Além disso a produção marciana, controlada por uma amplo sistema estatístico, conta com margens determinadas de excedente de trabalho, garantindo que mesmo nos setores nos quais há demanda de força de trabalho, tal demanda encontra-se dentro da margem de plena-produção. Essas condições, de acordo com Menni, garantem que as jornadas de trabalho não superem mais do que três horas diárias. Menni salienta que os dados estatísticos tratam de transferências massivas de trabalho, cabendo aos indivíduos trabalhar onde e da forma que quiserem (Bogdanov, 1984 [1908] : 68).

Algumas conclusões podem ser levantadas a partir do sistema de produção acima descrito. Bogdánov propõe em "Estrela Vermelha" uma forma de planejamento econômico descentralizado, amonetário, de trabalho voluntário e baseado na operação de amplos dados estatísticos que informam constantemente a demanda de força de trabalho a partir das necessidades de uso da sociedade. Também sabemos que os debates contemporâneos à obra referentes à planificação econômica eram essencialmente teóricos, voltados geralmente para formas distintas sobre o método de organização dos dados econômicos: por um lado, socialistas que defendiam formas centralizadas de planejamento em favor da determinação da produção a partir de um plano de metas; de outro, socialistas que defendiam um processo descentralizado de planejamento, organizado a partir de dados produzidos de oferta e demanda produzidos localmente. De acordo com Thomas Remington, mesmo na Rússia Soviética durante o período da Guerra Civil não era claro entre os economistas quais deveriam ser os fundamentos nos quais deveria se assentar o projeto de planificação da economia socialista, dada a necessidade constante de planos emergenciais em favor dos esforços de guerra (Remington, 1982: 586).

A resposta sobre as origens do modelo de planificação proposto por Bogdánov torna-se difícil devido à falta de interlocutores dentro do campo marxista 
que, em seu tempo, tenham realizado o mesmo esforço imaginativo ao qual ele se propôs. Novamente é necessário ler "Estrela Vermelha" como forma embrionária de conceitos que serão tratados com mais rigor posteriormente por seu autor. Tanto Belykh (1989) quanto Remington (1982) identificam em Bogdánov a origem da Teoria de Análise de "Input-Output" como ferramenta de orientação para o planejamento econômico. De acordo com essa teoria, apresentada por Bogdánov em janeiro de 1921 em uma conferência sobre processos de produção e organização científica do labor, todas as cadeias encontram-se organizativamente interconectadas. Tais interconexões são alimentadas em um circuito informacional e auto-regulatório que determina a proporcionalidade do sistema, cuja limitação é dada pelo "input" mais escasso. Essa lei que determina o limite de desenvolvimento de um dado sistema foi denominada por Bogdánov como a "Lei do Mínimo" (Belykh, 1989 : 428).

A partir da posição de proporcionalidade almejada em um determinado sistema produtivo, caberia ao processo de planejamento realizar iterações retroativas em toda a cadeia produtiva a partir do input-output de cada segmento, relacionando assim todos os diversos ramos da economia. Bogdánov partiu das observações de Marx em carta para Kugelmann em que aquele explicara que "o volume de produtos correspondentes a várias necessidades clama por várias e determinadas quantidades de trabalho social. [...] [a] forma com a qual essa divisão de trabalho social se manifesta em uma sociedade na qual a interconexão de trabalho social existe na forma da troca privada dos produtos individuais do labor é precisamente o valor de troca dos produtos" (Marx, 1868, apud Belykh 1990). A essa lei, que regula as proporções da economia de acordo com a condição de produção e que no capitalismo se manifesta pela Lei do Valor, Bogdánov denominou "Lei de custos do trabalho" (Belykh, 1990 :573). Tal lei, extraída de Marx, estabelece que tal proporcionalidade encontra-se presente em todas as formações econômicas e é por meio dela que se atinge uma condição de equilíbrio entre os diversos processos de input-output produtivos.

Bogdánov enxergou na lei de custos do trabalho exposta por Marx um estatuto semelhante à sua lei do equilíbrio dinâmico. "O equilíbrio da 
economia social é possivel quando através da distribuição cada um de seus elementos recebe todos os meios necessários para operar suas funções socioprodutivas" (Bogdánov, 1921, apud Belykh 1990:572). De acordo com Remington, as propostas de Bogdánov, Kritsman e Evgenni Varga - esse último importante economista húngaro e colaborador de Groman e Bazarov na elaboração do GOSPLAN - concentravam-se em três pontos principais: a regulação constante da realocação de recursos a partir de setores prioritários e em necessidade de maior demanda de forma a garantir o crescimento total de sistemas interconectados (Lei do Mínimo); a concepção de "ligação em cadeia" entre esses diversos setores, o que possibilita o cálculo iterativo de demanda e produção em um sistema bi-regulatório, de (sic) "feedback"; e o princípio de proporcionalidade, i.e. a aceitação de uma lei geral de equilíbrio, que produz com o acréscimo cada vez maior de dados uma função média de distribuição cujos desvios tornam-se cada vez mais irrelevantes. Esse equilíbrio por sua vez é de natureza dinâmica, sempre aberto para incorporar alterações na estrutura econômica, novos desenvolvimentos tecnológicos e consequente aumento de produtividade ${ }^{8}$ (Remington, 1982:591).

Bogdánov apresentou em "Estrela Vermelha" uma versão prototípica de sua teoria de planejamento econômico apresentada em 1921, baseada por sua vez em sua abordagem sistêmica da totalidade produtiva. Os três fundamentos da proposta apresentados acima (lei do mínimo, lei da cadeia e lei da proporcionalidade) encontram-se claramente expressos na descrição que Menni faz do funcionamento da produção marciana. A economia de Marte expressa no mais alto grau a forma ideológica do marxismo bogdanoviano: o equilíbrio dinâmico estabelecido entre uma infinidade de sistemas harmonicamente distribuídos em um continuum holístico, unificado pela experiência socialista e possível somente por meio da superação do grande fetichismo.

Por causa de sua concepção sistêmica e funcionalista, bem como do caráter

\footnotetext{
8 O desenvolvimento dos métodos modernos de análise por input-ouput são creditados a Vassili Leontief, economista russo radicado nos EUA e que recebeu em 1973 o Nobel de Economia por suas contribuições a partir dessa teoria. Belikh aponta que Leontief trabalhou estreitamente com Chayanov, economista soviético que modelou as primeiras tabelas de input-output agrícolas em 1926. De acordo com o autor, Chayanov era um entusiasta da Tektologia de Bogdánov e esteve presente na Conferência de Planejamento Econômico de 1921 onde Bogdánov apresentou suas ideias. Por essa razão, Belikh propõe Bogdánov como o fundador de facto da teoria de análise por input-output, ainda que o mesmo nunca tenha utilizado tal termo para descrever suas contribuições (Belykh, 1989:428).
} 
regulatório que Bogdánov confere a mecanismos de input-output, diversos pesquisadores enxergaram em Bogdánov o fundador das futuras ciências da Teoria Geral de Sistemas e da Cibernética (Gorelik 1980 : 329, Jensen 1978: 35, Gare $2000 a: 12$, Wark 2015:7). A despeito do flagrante anacronismo dessas posições - essas ciências se desenvolvem décadas depois das contribuições de Bogdánov em contextos históricos particulares - é seguro afirmar que Bogdánov antecipa, nos limites históricos dados e já expostos, alguns de seus conceitos centrais, como o princípio de cadeia e o "feedback". O sistema de produção marciano é claramente um sistema informacional, isto é, dependente do fluxo constante de informações. Sem explicar exatamente como se dá o processamento de dados - o que levou Rowley (1984:xxii) a classificar esse processo como "computacional" - Bogdánov descreveu, por meio de sua lei geral do equilíbrio, uma produção planificada "on-demand", cuja cadeia produtiva é alimentada quase que instantaneamente (de hora em hora) por dados de demanda de produção e força de trabalho disponível. Bogdánov apresentou uma concepção única de planificação econômica em "estrela Vermelha", cujo modelo vem sendo resgatado somente nas últimas décadas por meio dos trabalhos de pesquisadores marxistas que se debruçam sobre as possibilidades do socialismo digital (Wark 2015:62, Cockshott \& Cottrell 1993 : 30). A utopia marciana é assegurada pelo livre fluir de seus elementos: mercadorias, força de trabalho, sangue, água, informação. Sob a lógica de sua teoria geral de equilíbrio, toda a experiência encontra-se unificada em um amplo continuum que abarca desde as formas mais elementares de organização até as mais ricas e sofisticadas, expressas na organização informacional de sua produção. Em tais condições o Estado, enquanto entidade administrativa e mediadora das relações sociais, torna-se irrelevante, razão pela qual inexiste na utopia de Bogdánov. A sociedade marciana - sociedade tomada aqui como uma categoria ampla - atua como um organismo, um amplo sistema cujo funcionamento se realiza de forma automática, por meio de mecanismos regulatórios.

Em sua obra "A Sociologia de Marx" Henri Lefebvre nos fornece um panorama do desenvolvimento das reflexões de Marx acerca de uma Teoria do Estado. De acordo com o autor, a análise marxiana concentra-se no caráter 
de classe do Estado, historicamente determinado a partir da necessidade de coerção extraeconômica a ser imposto sobre as frações produtoras (Lefebvre, 1982 :156). É no processo de desenvolvimento da luta de classes, ditada pelas condições históricas dadas, que o Estado apresenta dupla natureza: por um lado é uma esfera da sociedade que ergue-se acima dessa, operando na condução política das classes dominantes quando essas encontram-se fracas demais para dar conta de sua missão histórica; por outro é a própria representação dessas mesmas classes, bem como de suas ideias e interesses (Lefebvre, 1982:178). Ainda que Marx se utilize desses significados em contextos diversos no percorrer de sua obra, encontramos como denominador comum o caráter social do Estado, isto é, sua emergência a partir das lutas que decorrem das relações de produção, em contraposição a uma suposta natureza meramente política e, portanto, idealista. Essa dualidade - estado como entidade/estado como expressão de classe - pode ser explicada, de acordo com Lawrence Krader, por uma cisão condicionada pelo processo de alienação que oculta o fundamento social, baseado na exploração e o subsume a um simulacro político, caracterizado pelo status formal-civil. Dessa forma o Estado, para Marx, é a forma em que uma determinada classe dominante expressa seus interesses em caráter universal ao mesmo tempo em que abarca a sociedade civil em sua particularidade histórica (Krader, 1979 : 277).

Marx anteviu na era de liberdade dos homens, i.e. no controle cônscio dos processos de reprodução da vida social, a dissolução do Estado. Esse desaparecimento está dialeticamente ligado à própria constituição de uma sociedade sem classes.

Esse processo é antecedido, como já vimos anteriormente, pela ditadura do proletariado, o controle político da classe produtora em contexto revolucionário. Para Engels e Marx, essa ditadura é necessária pela própria condição histórica que a classe trabalhadora e revolucionária encontra na sociedade de classes que é seu ponto de partida:

"Estado não é mais do que uma máquina para a opressão de uma classe por outra, e isso vale para a república democrática não menos que para a monarquia; na melhor das hipóteses, ele é um mal que o proletariado vitorioso herda na luta pelo domínio de classe e cujos 
piores aspectos o proletariado, assim como a Comuna, não pode evitar eliminar o mais prontamente possivel, até que uma nova geração, crescida em condições sociais novas e livres, seja capaz de remover de si todo esse entulho estatal". (Marx, 2011a:197).

A ditadura do proletariado encontra-se no passado de Marte, mas Bogdánov não tratou dela pormenorizadamente. Seu objetivo, mais que olhar para o passado era escrever para o proletário russo do presente sobre o futuro de seus descendentes. Seu objetivo era descrever a forma organizativa de uma sociedade que promoveu o definhamento do Estado a partir da superação da luta de classes. Bogdánov entendeu o Estado no sentido preciso daquele utilizado por Marx, uma entidade historicamente determinada pelas relações sociais que opera simultaneamente enquanto "balcão de negócios" da classe burguesa e esfera de controle físico e ideológico da totalidade social. O desaparecimento do conflito entre os homens leva consigo o Estado, enquanto expressão universal das ideias e desejos particulares das classes dominantes. Em seu lugar opera um sistema estatístico cuja função é garantir o equilíbrio produtivo da sociedade marciana e que é praticamente impérvio a desvios individuais. Nesse sentido é forçoso reconhecer a crítica de China Miéville à utopia marciana de Bogdánov. Esta carrega um elemento profundamente autoritário e impessoal que não oferece espaço para alteridade (Miéville \& Bould, 2009 : 129). O destino dos marcianos é ditado pelas tabelas do Instituto Central de Estatísticas em condições históricas sempre herdadas e das quais não há possibilidade de desvio.

\subsection{Socialismo da ciência: Tecnocracia e Coletivismo no Planeta Vermelho}

As transformações estruturais pelas quais passara o sistema capitalista na passagem dos séculos XIX e XX exerceram considerável influência no pensamento das intelectualidades socialistas russa e ocidental. Henri Lefebvre apontou como epicentro desse processo a confluência de dois fatores: por um lado o desenvolvimento da classe trabalhadora enquanto força social e política; 
e a crescente concentração de capitais. A ação dessas duas forças acabou por decompor o sistema-mundo em novas formas distintas, porém estreitamente relacionadas: o capitalismo monopolista, caracterizado pela centralização do Capital em grandes massas, cujo movimento supera as antigas fronteiras nacionais; o Capitalismo de Estado, caracterizado pela atuação do Estado como aparelho de coerção extra-econômica na busca cada vez mais agressiva por controle de mercados externos; e o espaço periférico composto por espaços abertos a ser explorados pelo Capital (Lefebvre, 1982 : 89-90).

O aumento de liquidez das massas de capital das potências ocidentais foi possibilitado por transformações tecnológicas nos setores de transporte e comunicações, acelerando sua internacionalização. Esse processo levou por um lado à crescente financeirização dos capitais nacionais, e por outro a relações cada vez mais beligerantes entre os Estados, ávidos pelo controle de novos territórios e mercados. Diferentemente do que defendem seus detratores esse processo não passou desapercebido por Marx. Como vimos anteriormente no Capítulo 3, Marx dedicou considerável energia para entender o processo de avanço das formas de mercado sobre espaços de sociabilidade não-capitalista, seja na Rússia, seja nas colônias britânicas asiáticas. É possível identificar na obra de Marx elementos fundantes dessas transformações e que formam o bojo teórico para sua teoria sistêmica de crises.

Partindo da forma fundamental do Capital, a mercadoria, Marx demonstrou que a reprodução ampliada do Capital depende de uma contradição fundamental já existente em sua forma mais simples: a negação dialética do Valor, tempo de trabalho socialmente necessário, a partir de uma valoração externa e estranha às suas características materiais, expressa pelo valor de troca. O Capital, Valor que se auto-valoriza, adquire uma forma autonomizada das relações que o produzem e passa a determinar essas mesmas relações. Tal determinação é sustentada pela expropriação de excedente de trabalho impresso nos frutos do trabalho - mais-valor - que por sua vez é a negação do trabalho enquanto ato social fundador e, consequentemente, fonte de todo o Capital (Marx, 2013:102). O caráter sistêmico das crises no capitalismo corresponde à impossibilidade de superação dessa contradição, cuja expressão qualitativa manifesta-se na queda tendencial das taxas médias de lucro. Essa 
tendência corresponde à redução da margem de realização do mais-valor devido à concorrência entre diversas massas de Capital. Tal concorrência por sua vez força os competidores a elevar a composição orgânica de seus capitais - o aumento proporcional do trabalho pretérito na forma de capital constante em relação ao trabalho vivo, produtor de mais-valor, na forma de capital variável. Esse movimento comporta um aumento das massas de capitais, ao mesmo tempo em que reduz, através do aumento de produtividade, o mais-valor impresso nas mercadorias (Marx, 2017 :255) individuais. A consequência desse processo é a redução da taxa geral de lucro que se acumula quantitativamente até sua transformação qualitativa: a crise. Esse é o momento em que o circuito é interrompido e as massas menores de capital são destruídas e incorporadas às massas maiores levando à concentração de Capital na forma de monopólios. Jorge Grespan demonstrou que a crise não compõe no sistema marxiano um elemento simples de negatividade, de caráter episódico. Ao contrário, a crise é um elemento constitutivo intrínseco do Capital, na exata medida em que determina o movimento de formas, modais, que o Capital desenvolve em direção a formas cada vez mais abstratas, mas que são incapazes de negar sua contradição essencial: negação do trabalho como ato social fundador do Valor (Grespan, 2012 : 25). De acordo com Marx, "o Capital move-se no interior de uma antítese" (Marx, 2017:303).

Foi através da teoria marxiana de crise que diversos intelectuais socialistas tentaram compreender o processo de transformação pelo qual passara o sistema capitalista nas primeiras décadas do século XX. Para além da crítica narodista exposta no Capítulo 3, tomemos a título de exemplo o trabalho de Rosa Luxemburgo em "A Acumulação do Capital", em que a autora discute a ascensão do imperialismo a partir da crise de subdemanda das economias industriais, cujos mercados encontravam-se saturados. Rosa demonstrou que tal condição favoreceu não apenas a militarização como novo espaço de acumulação para as massas inertes de Capital acumulado, mas que se origina no caráter tautológico do próprio processo de circulação, que força o Capital a buscar incessantemente novos mercados (Gomes, 2018:179). Lenin por sua vez identificou no imperialismo a expressão política de capitais cada vez mais financeirizados e em constante disputa pela conquista de novos mercados 
através do suporte bélico estatal. O aumento de liquidez dessas grandes massas de Capital possibilitou a reconfiguração de uma sistema de caráter global, incluindo enquanto espaços passíveis de colonização as periferias do sistema. Na linha de frente desse processo encontra-se o poder bélico dos Estados Nacionais, agora agentes diretos do processo de reprodução ampliada do Capital (Krausz, 2015 : 93).

Assim como Rosa Luxemburgo e Lenin, Bogdánov dedicou considerável esforço na análise dessas transformações. No entanto, dada a natureza empiriomonista de suas reflexões, Bogdánov dedicou muito menos espaço em seus trabalhos para o papel da crise nesse processo. Bogdánov se interessava mais nos elementos que garantiam a resiliência desse sistema frente à condição crônica da crise e menos no processo dialético que produzia a ruptura no circuito do Capital. Enquanto Lenin e Rosa Luxemburgo eram movidos pelas implicações táticas de uma teoria do imperialismo a partir da crise do Capital, a questão a ser tratada por Bogdánov era compreender como o sistema conseguia manter sua coesão ainda que afetado integralmente por elementos desorganizacionais. Bogdánov buscou na interação entre o desenvolvimento técnico das forças produtivas e as relações de produção a resposta para essa questão.

Como vimos anteriormente, Bogdánov concede à tecnologia, senão a primazia, certamente um papel hierarquicamente superior na relação triática entre a técnica, ideologia e relações de produção (Seção 4.7). É o nível técnico da produção que atua na fronteira do sistema social, no confronto entre o homem e a natureza, que estrutura as relações de produção, das quais partem as formas ideológicas que organizam todo o sistema. Essa concepção "tecnocrática" da relação entre as forças produtivas e as relações de produção fora fundamental no desvio que Bogdánov realizou a partir da concepção marxista de classe: uma classe não é determinada pelo nível de acesso aos frutos do trabalho social, mas pelo papel organizacional que a classe exerce sobre a produção. A classe dominante de um determinado período histórico é a classe que controla os meios organizacionais das forças produtivas e determina por conta disso não somente as formas de produção e a divisão social do trabalho, mas também os elementos ideológicos que reforçam 
essas mesma relações (Sochor, 1988:63). Devemos ressaltar novamente que Bogdánov compreende a ideologia como fruto da interligação entre as relações econômicas e as condições técnicas, ainda que a mesma desenvolva um papel parcialmente independente - organizativo - de todo o sistema.

Essa concepção organizacional de classe já se encontrava presente nos primeiros trabalhos de Bogdánov. Em "Curso Curto de Economia Política", Bogdánov tentou explicar historicamente o surgimento do trabalho especializado a partir do crescimento da produção: o "gerenciamento do trabalho representa historicamente a forma primeva de trabalho complexo" (Bogdanov, 1932 : 32). Para Bogdánov, o avanço das forças produtivas acaba por fragmentar a sociedade em classes, a partir das relações de autoridade e subordinação, e em grupos sociais, a partir das relações técnicas de produção. Essas duas categorias conceituais estão fundamentalmente imbricadas no pensamento de Bogdánov: a tarefa organizativa da produção é determinada pelo tipo de apropriação do produto social do trabalho estabelecido pelos organizadores, i.e. a classe dominante. Essa determina, a partir do controle organizativo do trabalho, as relações de autoridade e subordinação que determinam as formas do trabalho e a distribuição de seus frutos. A forma ideológica - que emerge das relações de autoridade e subordinação - fornece o modelo no quais se organizam as classes sociais. Bogdánov explica isso pelo fato de que uma classe não organiza somente o processo de trabalho; ela organiza pessoas. No capitalismo a classe dominante assegura seu domínio das forças produtivas por meio da alocação de recursos e trabalho, organizando assim toda a atividade produtiva a partir de uma relação expropriativa e autoritária sobre a organização social do trabalho. Para Bogdánov a característica histórica do Capitalismo é "a transformação dos meios de produção em meios de expropriação através da propriedade privada" (Bogdanov, 1932:141).

Essa divisão entre classe e grupo social somente foi possível a partir das transformações pelas quais passava o sistema capitalista. O avanço das forças produtivas e a crescente internacionalização do Capital trouxe transformações profundas nas relações de produção. O desenvolvimento do capitalismo monopolista propiciou o surgimento de grandes holdings internacionais compostos por diversas empresas mais ou menos autômomas. Nessa nova ordem do 
sistema produtivo fez-se necessário o surgimento de um grupo de trabalhadores diretamente ligados às tarefas organizativas do trabalho, cuja função diferia daquela realizada pelo "capataz" (que supervisiona os trabalhadores) ou mesmo do proprietário (que supervisiona a produção) mas que engloba ambas. A esse grupo Bogdánov denominou "Intelligentisa burguesa".

Esse grupo social emerge da divisão técnica do trabalho e comporta desde analistas e engenheiros até pesquisadores e gerentes. Diferentemente dos capitalistas, cabe à Intelligentisa burguesa considerável controle dos meios de produção, sem contudo lhe caber sua propriedade. Sua natureza gerencial é determinada pela papel organizativo que exerce, i.e. pela dimensão especializada do trabalho e por isso não pode ser considerada uma classe, tão somente um grupo. Esse estrato de trabalhadores especializados, por não terem seu salário determinado pelas formas convencionais de exploração, desenvolveriam interesses de grupo pelo lucro do capitalista; por outro lado, a convivência diária com a classe produtiva os imbuiria dos elementos ideológicos do socialismo, o que explicaria, de acordo com o autor, a simpatia que os estratos mais baixos da "Intelligentsia técnica" nutrem pela classe operária (Bogdanov, 1932:49).

No avançar da luta de classes, esse grupo social encontra-se simultaneamente entre as classes proprietárias e subordinadas. Sua condição é não-determinada, contraditória, variando conforme varia o posicionamento de forças das classes antagônicas. Bogdánov defendia que esse estrato só poderia ser adequadamente analisado se fossem consideradas as relações de autoridade como fatores determinantes do processo organizacional. A Intelligentsia burguesa, ainda que indeterminada enquanto classe, tem um papel definido nas relações de autoridade típicas da organização capitalista: ela reforça por meio do controle organizacional essas relações, pois derivam seu poder da classe proprietária (Bogdanov, 1932 : 42). Bogdánov buscou, de acordo com Sochor 1988:122, salientar aquilo que entendia como uma inadequação da teoria de classes marxista de seu tempo: explicar uma classe de fenômenos - relações autoritárias - através de outra classe de fenômeno - relações de propriedade. Ambas as classes de fenômenos exercem papel na estrutura das relações de produção de uma dada sociedade e precisam ser pensadas 
na relação com essa totalidade. No entanto, para entender a atuação da "Intelligentsia" técnica e seu papel na luta de classes é fundamental que tais classes de fenômenos sejam compreendidas como elementos interconectados, porém distintos (Sochor, 1988:66).

Para entendermos a importância que essa decomposição do conceito de classe exerceu sobre as reflexões políticas de Bogdánov, é preciso interpretar a função da Intelligentsia técnica de acordo com sua teoria empiriomonista. Enquanto gerenciadores do processo produtivo, seu papel é majoritariamente organizacional e, portanto, ideológico. A ideologia por sua vez ascende da relação de causalidade abstrata característica do modo de produção capitalista, que fragmenta a experiência em átomos individuais, apartando as experiências individuais da experiência coletiva. Esse processo resulta não somente na divisão social do trabalho subordinada à lógica de produção expropriativa expressa pela cisão entre trabalho assalariado e propriedade privada, como também gesta inúmeras dicotomias de terceira ordem: ciência e filosofia; matéria e espírito; sujeito e objeto. O processo de fragmentação e autonomização de aspectos da experiência dificulta a percepção dessas relações de exploração enquanto fundamentos caracteristicamente autoritários da divisão do trabalho social. Os indivíduos tornam-se incapazes de compartilhar socialmente a experiência coletiva, uma vez que a própria ciência - a experiência organizada de uma sociedade em dado momento histórico torna-se cada vez mais especializada, reforçando assim a divisão social do trabalho em moldes autoritários ao separar os homens entre organizadores e executores. Ao mesmo tempo em que o avanço das forças produtivas torna a produção cada vez mais dependente do desenvolvimento científico, sob a causalidade do sistema de trocas tal avanço também faz acelerar a fragmentação da experiência, condição fundamental para aquilo que Bogdánov denominou "visão-de-mundo burguesa", caracterizada pelo fetichismo, individualismo e por relações de produção autoritárias.

A Intelligentsia burguesa - também denominada por Bogdánov como Intelligentsia técnico-científica - é, no processo de divisão social do trabalho, a portadora do conhecimento científico, i.e. da experiência coletiva acumulada pela práxis da produção. Sua função é organizativa e portanto ideológica. 
Sob efeito da causalidade abstrata, tal grupo social acaba por reproduzir e reforçar os elementos ideológicos que compõem a visão-de-mundo burguesa, cuja composição emerge das relações práticas de produção dominadas pela forma impessoal (fetichista) de escravidão. Bogdánov no entanto não reduziu a Intelligentsia Burguesa a mera guardiã das estruturas ideológicas historicamente constituídas. Ao mesmo tempo em que organizam as forças produtivas, esses intelectuais encontram-se em contato direto com a práxis produtiva da classe trabalhadora, baseada no coletivismo e na maquinofatura. Dessa forma a Intelligentsia burguesa gravita entre as causalidades autoritária e do labor; entre relações de produção autoritárias e cooperativas.

As reflexões de Bogdánov acerca da Intelligentsia burguesa produziram interpretações conflitantes entre os pesquisadores que escreveram sobre o assunto. Para John Biggart, Bogdánov considerava a Intelligentsia burguesa um perigo ao desenvolvimento das organizações de trabalhadores. Esse risco advinha daquilo que Bogdánov entendia ser uma inevitável tendência ao individualismo e autoritarismo, elementos característicos da visão-de-mundo burguesa. Bogdánov temia que, sob a liderança de uma vanguarda composta por um estrato social intermediário e de fortes tendências autoritárias, o proletariado acabasse subjugado, sem que o mesmo atingisse o despertar de sua consciência - a constituição da visão-de-mundo do labor (Biggart, 1990 : 273-275). A favor de Biggart, devemos apontar que, de fato, Bogdánov culpabilizou a Intelligentsia pelo fracasso da Revolução de 1905 ao se afastar da luta dos trabalhadores em prol de saídas parlamentares, substituindo o esforço revolucionário por aquilo que ele denominou "ilusões constitucionais" (Bogdánov, 1907, apud Biggart 1990 : 269).

John Eric Marot apresentou uma interpretação oposta acerca do posicionamento de Bogdánov em relação à Intelligentsia. Marot enfatiza a plataforma vperedista para argumentar que Bogdánov defendera um papel tutelar a ser exercido pela Intelligentsia sobre a classe trabalhadora. A partir da experiência de 1905, Bogdánov decidiu-se pela impossibilidade da aquisição espontânea da consciência pela massas insurretas. No centro dessa crítica encontrava-se a recusa em reconhecer o caráter revolucionário das próprias organizações trabalhadoras (clubes, sindicatos, etc..), uma vez que 
tais entidades operavam dentro das leis econômicas e culturais do Capitalismo e seriam por isso incapazes de fazer ascender a consciência revolucionária (Marot, 1990 : 265). Caberia aos intelectuais tutelar o desenvolvimento da classe trabalhadora em direção a uma nova visão de mundo que integrasse as diferentes esferas da experiência em uma totalidade harmônica. Marot ressalta o caráter pedagógico do projeto vperedista e a função de liderança que cabe à Intelligentsia nesse contexto. De acordo com Marot, a concepção bogdanoviana consiste em realizar externamente o processo de conscientização através da educação das massas (Marot, 1990 : 259).

A despeito das importantes contribuições realizadas por ambos os pesquisadores para a recuperação da obra de Bogdánov, é forçoso dizer que ambas as abordagens partem de premissas corretas sem contudo atingir o alvo: o papel que Bogdánov dedica à Intelligentsia burguesa no processo revolucionário. Esse papel não pode ser descrito por categorias estanques, uma vez que a Intelligentsia opera a partir de uma posição derivada na luta de classes. No entanto, a abordagem temporal desses dois autores nos abre uma interessante possibilidade: "Estrela Vermelha" foi produzida entre os marcos temporais utilizados por Biggart e Marot e, portanto, se inscreve em um contexto intermediário entre a crítica à participação parlamentar de 1907 e a plataforma vperedista de 1910. Através da leitura de "Estrela Vermelha" é possível compreender de forma mais rica a crítica bogdanoviana à Intelligentsia e o papel que Bogdánov acreditava lhe pertencer na construção do socialismo.

Leonid, o protagonista de "Estrela Vermelha", é um típico representante da Intelligentsia burguesa. Profundamente envolvido no processo revolucionário de 1905, Leonid se descreve, a despeito de sua juventude, como "um membro da velha guarda do partido dos trabalhadores" com seis anos de serviço e um ano de encarceramento. Sua dedicação à causa da revolução no entanto não ofuscou seus interesses intelectuais. Leonid é um cientista que "se encontrava particularmente interessado na estrutura da matéria e se sustentava escrevendo para duas revistas infantis" (Bogdanov, 1984 [1908] : 24). Já no quarto parágrafo de sua obra Bogdánov deixa claro que seu protagonista não é um revolucionário saído das fileiras de trabalhadores. 
Leonid é um cientista e escritor. Seu sustento advém do trabalho intelectual. Como veremos adiante, essa condição é fundamental no desenvolvimento narrativo de "Estrela Vermelha".

Durante sua viagem para Marte Leonid torna-se vítima de um acidente no laboratório de química do Etherofeno e acaba sendo salvo por Letta, o químico da expedição. Enquanto Leonid visitava tal laboratório, uma explosão acidental abre um rombo na casco do veículo que passa a sofrer de violenta descompressão. Letta, ao perceber que ambos pereceriam, liberta-se do suporte e usa o próprio corpo para tapar a avaria, falecendo no processo (Bogdanov, 1984 [1908]:50). Leonid não apenas fica perturbado com a tragédia como bastante confuso: ele não conseguia conceber o sacrifício de Letta, a razão pela qual o marciano fez o que fez.

Aquilo que Leonid não conseguia compreender encontra-se no caráter coletivista da visão-de-mundo marciana. Todas as ideias, mitos e ideologias, de acordo com Bogdánov, não passam estruturas mentais que organizam a experiência. Tais elementos psíquicos-subjetivos encontram-se distribuídos hierarquicamente de acordo com o grau de conexões que compartilham com os elementos da experiência físico-objetiva, determinada pela atividade social. Sob o efeito da causalidade burguesa, fundada em relações de produção baseadas na propriedade privada, na luta de classes e na atomização da produção, os elementos subjetivos da experiência autonomizam-se, fragmentando-se em um sem número de dicotomias, "absolutos" que parecem existir apartados da atividade social, fonte de toda a experiência. Esses "absolutos", expressos em relações dicotômicas, são reflexos da divisão da sociedade em classes antagônicas e representam a partir da ordem organizacional que gozam na hierarquia da experiência social o caráter autoritário da sociedade burguesa. No socialismo, por outro lado, a partir da visão de mundo operária que emerge da causalidade do labor, tais dicotomias deixam de existir uma vez que seus elementos passam a ser vistos como aspectos psíquicos da experiência social total. Sua integralidade, antes fragmentada em dimensões subjetiva e objetiva, é restaurada com o fim da sociedade de classes e do domínio da maquinofatura.

Williams (1980:391) relacionou, com algumas limitações, a utopia da 
imortalidade do coletivo com os fundamentos empiriomonistas a partir do quais Bogdánov imaginou a sociedade marciana. Levando os postulados de Bogdánov ao extremo, o "Eu" é absorvido pela experiência total e desaparece enquanto fenômeno do fetichismo característico das sociedades capitalistas. $\mathrm{O}$ ego é apenas um fetiche, uma forma organizacional da experiência apartada do organismo social, cuja função é adequada somente para aquela sociedade. No socialismo marciano o universo adquire uma natureza holística, na qual o "eu" é uma parte componente da totalidade e não um aspecto que lhe é separado.

Por que Letta prontamente se sacrificou para salvar a vida de Leonid? Porque, se a experiência compõe a totalidade social e unifica todos os aspectos da atividade humana, o "Eu" é tão somente uma hipótese. Não há morte em Marte. Há somente a transformação da experiência total, uma mudança nos fluxos de energia que regulam o sistema. O indivíduo continua a existir, transmutado na sobrevivência do coletivo, cuja experiência avança indefinidamente. Enquanto a imortalidade individual é desejo e mito de uma sociedade de classes, sob o socialismo a imortalidade é transfixada no devir do coletivo, no qual todas as experiências e individualidades sobrevivem subsumidas.

Essa subsunção do "Eu" encontra-se presente em outros momentos da obra. Tomemos como exemplo a passagem em que Netti explica pra Leonid que não há monumentos dedicados a indivíduos em Marte, já explorada no Capítulo 3 (p. 113). Leonid demonstra grande dificuldade em aceitar a inexistência de elementos egressivos no sistema social marciano i.e. indivíduos ou mesmo ideias que concentrem e centralizem as forças que operam o sistema social marciano. A sociedade marciana é um enorme organismo, cuja sobrevivência é o propósito máximo de cada indivíduo.

Bogdánov dedica considerável esforço para mostrar que tal coletivismo não é uma aptidão, uma condição natural dos marcianos. Ela é cuidadosamente cultivada através do sistema educacional marciano e desvios de comportamento são considerados doenças clínicas e tratados em hospitais e sanatórios. Durante sua visita à colônia de crianças, Leonid testemunha a altercação entre duas delas por causa da propriedade de um barco de brinquedo. Após solicitar para uma criança maior que acompanhasse o garoto e convencesse a 
colega a brincarem juntos, Nella explica:

"Nosso comunismo parece completo; nós quase nunca precisamos negar qualquer coisa para as crianças. De então poderia vir uma noção de propriedade privada? No entanto uma criança de repente se aproximará e começará a falar sobre "meu" barco, "aquele que eu fiz". Tais coisas são bastante comuns e às vezes terminam mesmo em brigas. Não há o que fazer. De acordo com uma lei universal da vida o desenvolvimento do organismo repete em forma abreviada o desenvolvimento da espécie. De forma análoga, o desenvolvimento do indivíduo repete o desenvolvimento da sociedade" (Bogdanov, 1984 [1908]: 70).

Nella ainda explica que essa situação ainda é mais acentuada em adolescentes e somente "no início da vida adulta é que o ambiente social é finalmente capaz de conquistar os vestígios do passado" (Bogdanov, 1984 [1908] : 70). Essa passagem nos permite tirar duas conclusões: a primeira se refere a uma das diversas teorias da biologia que influenciaram o pensamento de Bogdánov: a lei universal da vida corresponde à teoria da recapitulação de Ernst Haeckel. Haeckel defendeu exatamente aquilo que foi postulado por Nella: o desenvolvimento de um indivíduo reflete em uma escala curta de tempo as transformações pelas quais passou sua espécie em um tempo de longuíssima duração. Ainda que desacreditada (Haeckel foi acusado e culpado de fraude), a teoria da recapitulação exerceu, de acordo com Greenfield, considerável influência entre os intelectuais positivistas do século XIX. Bogdánov, afeito à busca por padrões entre sistemas orgânicos e sociais, transplantou para o desenvolvimento das crianças marcianas uma versão dessa teoria como forma de explicar comportamentos atávicos no interior da sociedade marciana (Greenfield, 2006: 631).

Essa passagem, embora curta, nos apresenta um segundo problema: o caráter totalizante do coletivo marciano. Nella observa que, fatalmente, o coletivo supera tais heranças atávicas. Um marciano adulto é um indivíduo extremamente conformado ao coletivo. Essa percepção é reforçada pelo fato de que Bogdánov não se preocupou em descrever quaisquer momentos de prazer ou mesmo de privacidade. O marciano demonstra um caráter estoico, pronto para o sacrifício e totalmente devotado ao sistema social. Em parte, 
isso não é surpresa. Bogdánov, como muitos revolucionários de seu tempo, são depositários de um importante arcabouço teórico e imagético da Intelligentsia raznochinets do século XIX que alimentou não somente a teoria e tática social-democratas como também a própria imagem do revolucionário russo, composto de rocha e metal. Esse caráter extremamente racional aparece na descrição de importantes personagens marcianos. Menni é descrito por Leonid como alguém que "reduzia todas as questões táticas individuais às suas fundações ideológicas gerais. (...) suas colocações eram sempre formuladas de forma gentil e sensivel, mas que sempre iam direto ao ponto" (Bogdanov, 1984 [1908] : 26). A descrição de Sterni é ainda mais radical. Sterni: "[Sterni] tem um intelecto muito poderoso, porém frio e quase que totalmente analítico. Ele desmonta tudo, lógica e implacavelmente e suas conclusões são muitas vezes parciais e outras vezes extremamente severas" (Bogdanov, 1984 [1908] :45).

Essa racionalidade estoica é a norma comportamental da sociedade marciana. Sua lógica é de uma racionalidade profundamente instrumental, afiada no confronto perpétuo com a natureza. Desvios são encarados como doenças mentais ou atavismos infantis e tratados de acordo, seja por médicos ou pedagogos. A violência desnecessária e excessiva, de acordo com Netti, somente é possível "no caso de alguém que está doente e que necessita de tratamento. Uma pessoa consciente e razoável é, claro, incapaz de tal feito" (Bogdanov, 1984 [1908]: 83).

No decorrer da narrativa fica gradativamente claro que Leonid é incapaz de se adequar ao coletivismo marciano. Sua psique está indelevelmente estruturada por uma visão de mundo burguesa, individualista e marcada por conflitos. Essa situação não se dá por uma suposta fraqueza psicológica. Por meio da conversa entre Leonid e Nella na visita ao museu, o autor deixa implícito que essa dissociação afetaria os marcianos de igual maneira, caso fossem eles os visitantes. Ao questionar um conceito perfeito de felicidade, Nella apresenta uma inversão do problema de Leonid:

"Eu vi seu mundo e eu não seria capaz de tolerar uma fração da insanidade na qual vocês camaradas vivem. Por essa razão eu não posso presumir decidir qual de nós está mais próximo de uma felicidade tranquila." (Bogdanov, 1984 [1908]:80) 
Após a visita ao museu, Leonid se sente cansado e incapaz de dormir e decide visitar Netti no hospital. Lá, sob os cuidados da doutora, ele recebe um tratamento tranquilizante a partir do uso de luzes e cheiros. Ao sair do hospital Leonid se dá conta da enormidade de sua tarefa:

"A tempestuosa corrente de impressões que me engolfou durante meus primeiros dias em Marte deu-me uma ideia da gigantesca tarefa que me confrontava. Primeiro de tudo, eu precisava compreender esse mundo e sua imensuravelmente rica e original harmonia vital. Eu então deveria penetrá-la, não como uma curiosa peça de museu, mas como um homem entre homens, um trabalhador entre trabalhadores. Apenas então eu seria capaz de completar minha missão. Apenas então eu seria capaz de servir como uma ligação inicial de comunicação mútua entre nossos dois mundos. Como um socialista, eu me equilibrava na fronteira entre eles, como um átimo de segundo do presente entre o passado e o futuro." (Bogdanov, 1984 [1908]: 86)

Leonid passa então a estudar o método científico marciano e se mostra incapaz de compreendê-lo. Ele sabia por experiência que tal método poderia ser aplicado facilmente a qualquer hipótese científica e no entanto não conseguia compreender como tal método se relaciona com os fenômenos reais: "Era como aqueles matemáticos do século XVII cujo pensamento era organicamente incapaz de apreender o dinamismo vivo das quantidades infinitamente pequenas" (Bogdanov, 1984 [1908]). A partir desse ponto já nos é claro que Bogdánov expressa na incapacidade de Leonid em compreender a "ciência universal dos marcianos" aquilo que considera a causa das críticas infundadas à sua abordagem empiriomonista feita pelos marxistas ortodoxos. Leonid, assim como suas contrapartes social-democratas, não consegue dominar tal ciência pois carrega em si elementos ideológicos burgueses, que exigem a existência de "fenômenos reais", i.e. a coisa-em-si. O caráter intersubjetivo da matéria como reino da resistência à atividade social é característica fundante do marxismo bogdanoviano, que recusa qualquer forma de realidade objetiva, condicionando-a sempre a uma experiência historicamente determinada.

Essa inadequação se repete em todos os aspectos da vida social e produtiva dos marcianos com as quais Leonid entra em contato. Essas duas passagens tratam, respectivamente, das impressões de Leonid a respeito de uma reunião de especialistas e da arte marciana: 
"Seja lidando com tópicos científicos, questões relacionadas à organização do trabalho ou mesmo problemas artísticos, seus relatórios e discursos eram extremamente concisos e breves; sua argumentação, rigorosa e precisa. Ninguém nunca se repetia para os outros. As resoluções dos encontros eram, geralmente, adotadas unanimemente $e$ com incrível rapidez." (Bogdanov, 1984 [1908] : 87)

"A literatura desse mundo, mesmo a pura ficção, não me gerava descanso ou relaxamento. Suas imagens pareciam simples e claras, mas de alguma forma permaneciam alienígenas pra mim. (...) Eu era atormentado pela mesma incompreensibilidade quando fui ao teatro. As tramas eram simples, a atuação soberba, mas a realidade me confundia. As falas dos protagonistas eram tão reservadas e gentis, seu comportamento tão calmo e sóbrio, seus sentimentos tão raramente expressados como se eles estivessem tentando evitar evocar quaisquer respostas emocionais no espectador" (Bogdanov, 1984 [1908]: 87)

Leonid começa a sofrer de exaustão por conta do permanente estranhamento. Sua estabilidade mental começa a erodir, impedindo que o jovem socialista se concentre nas tarefas mais simples. Após um desmaio, Leonid desperta sob os olhares de Anna Nikolaevna, sua antiga amante bolchevique. Ele passa a sofrer de alucinações que se estendem por semanas a fio, mesmo sob o tratamento cuidadoso de Netti, a quem Leonid descobre ser uma mulher e de quem se tornara amante (Bogdanov, 1984 [1908] : 92).

Ao tornar-se um trabalhador produtivo na sociedade marciana, Leonid descreve todos os preparativos necessários para exercer tal papel:

"O trabalho, é claro, era um dos mais simples que havia, mas ainda assim fui forçado a fazer consideráveis preparativos. Eu precisei estudar os princípios científicos da organização industrial e me familiarizar em particular com a estrutura da fábrica na qual eu seria empregado, incluindo sua arquitetura e gerenciamento. Além disso, precisei adquirir uma noção geral de todas as máquinas em uso ali e em detalhes da máquina no qual estaria trabalhando. Isso me obrigou a aprender de antemão certos ramos de mecânica teórica e aplicada mesmo análise matemática." (Bogdanov, 1984 [1908]:96)

Tais conhecimentos, ainda que necessários, se mostram insuficientes para que Leonid acompanhasse o ritmo dos trabalhadores marcianos. Esses trabalhavam como um único organismo, enquanto Leonid necessitava de muito 
mais esforço para manter a concentração. No momento em que ele perde a concentração e comente um erro, o trabalhador vizinho rapidamente corrige seu desvio. Leonid fica exasperado com a habilidade dos seus camaradas em observar tudo o que acontece à sua volta sem negligenciar o próprio trabalho (Bogdanov, 1984 [1908] : 99) e passa a se ressentir do auxílio prestado, atrapalhando ainda mais o seu desempenho. Posteriormente, Leonid percebe que ele não estavam sendo condescendentes com suas dificuldades:

"(...) meus camaradas da fábrica ajudavam uns aos outros exatamente da mesma maneira e com a mesma solicitude, ainda que mais raramente. (...) em acordo com meus antecedentes individualísticos, era eu que estava me isolando inconscientemente dos outros. E novamente, como uma criança de uma cultura materialística, eu interpretei incorretamente seus gestos camaradas porque me senti incapaz de retribuí-los." (Bogdanov, 1984 [1908] : 100)

Leonid encontra-se preso entre dois mundos aparentemente incompatíveis, cujas relações sociais operam a partir de visões-de-mundo fundamentadas em sistemas ideológicos díspares: de um lado, o individualismo da visãode-mundo fetichista; do outro, o coletivismo da visão-de-mundo socialista. Bogánov preenche a estadia de seu herói com episódios cada vez mais agudos de alucinações, depressão, exaustão e fúria. Bogdánov se utilizou de sua formação como médico psiquiatra para fazer descrições bastante realistas desses episódios, objetivando realçar a espiral descendente em que cai a consciência de Leonid. O clímax da obra se dá quando Leonid descobre no museu transcrições das atas de reunião de uma organização denominada "Grupo Colonial", composto por representantes do Instituto Central de Estatísticas e cientistas engajados em organizar viagens interplanetares. Ao ouvir a transcrição, Leonid descobre que Marte encontra-se à beira da catástrofe: de acordo com o representante do Instituto Central de Estatísticas, caso os marcianos se restrinjam a explorar somente os recursos de seu planeta, prevê-se uma crise alimentar nos próximos trinta anos. Tal crise pode ser evitada caso se desenvolva uma técnica que permita sintetizar proteínas a partir de matéria inorgânica, técnica essa que não se encontra no horizonte. Diante disso, resta uma única solução a médio prazo: a colonização em massa de outros planetas. (Bogdanov, 1984 [1908] : 110) 
Duas possibilidades se abrem nesse sentido: acelerar o processo de aclimatação de Vênus, considerado irreal para os cientistas presentes; ou colonizar a Terra, rica em recursos, cujo ecossistema encontra-se pronto para receber a população marciana.

Sterni, o frio matemático, é a principal voz a favor da última proposta. Ele defende que a terra está pronta para a colonização e apresenta um único obstáculo: a humanidade:

"Os povos da Terra são mestres do planeta e, sob nenhuma circunstância, alienarão qualquer parte significativa de sua superfície. Tal relutância deriva da própria natureza de sua cultura, a qual é baseada na propriedade privada protegida pela violência organizada. (...) o saque sistemático das terras e pertences de povos menos desenvolvidos recebe o nome de política colonial e é considerado uma área maior em sua vida politica" (Bogdanov, 1984 [1908] :110-111)

Além das políticas colonialistas, Bogdánov destaca, a partir do discurso de Sterni, um segundo fundamento ideológico do crescente imperialismo das potências europeias que estrutura o desenvolvimento dos setores bélicos enquanto áreas privilegiadas para o escoamento de capitais: o patriotismo.

"Em seus infindáveis conflitos internos, os povos da Terra desenvolveram uma peculiaridade psicológica a qual eles denominam patriotismo. Essa emoção difusa, porém forte e profundamente enraizada, inclui uma desconfiança raivosa de todos os outros povos e raças, uma ligação visceral a um particular estilo de vida - especialmente com o território com o qual cada povo se fundiu, como uma tartaruga com seu casco uma certa auto-consciência coletiva e comumente, evidentemente, um desejo simples por destruição, violência e saque." (Bogdanov, 1984 [1908] :111)

Sob a lógica do colonialismo, Bogdánov parece concordar antecipadamente com Rosa Luxemburgo: a militarização é fundamental para o processo de acumulação primitiva no contexto imperialista, i.e. a destruição das organizações sociais tradicionais e imposição violenta da economia de mercado (Luxemburgo, 1970 : 399). Sterni ainda argumenta que, mesmo sob conquista violenta, qualquer colônia marciana precisaria enfrentar o fervor patriótico dos terranos derrotados, o que tornaria tal colônia uma fortaleza militarista 
e já não seria mais marciana no sentido em que os habitantes de Marte reconhecem sua própria cultura. Essas condições apontam para uma única solução: o extermínio total da humanidade. Bogdánov se utiliza de duas personagens através desse debate, Sterni e Netti, para expôr suas posições em relação ao programa tático da social-democracia russa. Sterni, frio e calculista, apresenta suas críticas àquilo que entende como falhas centrais do programa; Netti, a médica, propõe suas soluções. Assim como diversas obras de FC utópicas, a narrativa é muitas vezes apenas um medium para expressar a crítica ao contexto que a produz. O extermínio da humanidade é somente a forma que tal crítica utiliza para transmitir um conteúdo. É possível construir o socialismo em meio à ascensão do Imperialismo?

Sterni seguramente é contra essa possibilidade. Diante da proposta em auxiliar os movimentos revolucionários terranos e educar suas massas para o socialismo, Sterni contrapõe essa alternativa a partir de diversas condicionantes:

"Ela (Netti) está pensando na reeducação socialista imediata dos povos da Terra. (...) Eles estão sobre a influência do Capital. Eles também têm um proletariado lutando pelo socialismo. (...) o capitalismo na Terra, no entanto, possui certas características importantes as quais alteram consideravelmente o assunto. (...) Em primeiro lugar a Terra é terrivelmente tomada por divisões políticas e nacionais. A luta pelo socialismo é fragmentada em uma variedade de processos únicos e autônomos em sociedades individuais como sistemas políticos distintos, linguagens e mesmo raças. Em segundo lugar, os métodos de luta social lá são muito mais crus e mecânicos do que foi o caso conosco e violência física na forma de exércitos e revoltas armadas exercem um papel incomparavelmente maior lá do que já exerceu em Marte." (Bogdanov, 1984 [1908] : 113)

A natureza fragmentada da experiência que perfaz todos os aspectos da existência - físico/objetiva e psíquico/subjetiva - são fatores limitantes para o desenvolvimento do socialismo terrano. Através de Sterni, Bogdánov projeta um exercício imagético sobre o possível futuro socialista sob essas condições:

"Os países avançados nos quais o socialismo triunfar serão como ilhas em um mar hostil capitalista - mesmo pré-capitalista em alguma extensão. Ansiosos sobre o seu poder, as classes dominantes dos países 
não-socialistas continuarão a concentrar todos os seus esforços para destruir tais ilhas. Eles constantemente organizarão expedições militares contra esses países e serão capazes de encontrar aliados capazes de cometer traição entre os antigos grandes e pequenos proprietários das nações socialistas. É difícil prever o resultados desses conflitos, mas mesmo nos episódios em que o socialismo resistir e triunfar, sua natureza será profundamente pervertida por um longo período de isolamento, terror inevitável, militarismo e patriotismo bárbaro. Esse socialismo será muito distante do nosso. (...) Séculos de divisão nacional, a falta de compreensão mútua e uma luta brutal e sangrenta deixarão marcas profundas na psicologia da humanidade terrana liberada. Nós não sabemos quanta barbárie e miopia os socialistas da Terra trarão com eles em sua nova sociedade." (Bogdanov, 1984 [1908] :114)

Sterni também recusa a intervenção direta dos marcianos de forma a auxiliar o processo revolucionário. O proletariado ainda compõe uma minoria mesmo nos países mais avançados, nos quais seus números são superados pela pequena-burguesia e as enormes massas campesinas, cujas características ideológicas são fortemente reacionárias e reagem violentamente a transformações rápidas (Bogdanov, 1984 [1908] : 115). Esse trecho é deveras interessante pois nos permite assumir um diálogo, mesmo que limitado entre as reflexões de Bogdánov e a Teoria da Revolução Permanente de Trotsky, desenvolvida a partir da Revolução de 1905, obra com a qual certamente o autor se familiarizou ainda que não a cite. Essa relação demonstra pontos de contato e divergência e acaba por propôr uma abordagem diacrônica, uma vez que as posições de Bogdánov - fundadas em sua heterodoxia empiriomonista - antecipam elementos maduros da disputa política em relação ao caráter nacional/internacional da revolução em mais de 10 anos.

De acordo Löwy (1981:55-56), a concepção de revolução permanente de Trotsky, elaborada a partir da experiência de 1905, trata principalmente da relação entre o proletariado e o campesinato no processo revolucionário. Trotsky acreditava que a aliança entre as duas classes teria sempre um caráter transitório, determinado pela dissolução das formas de dominação absolutistas. A ditadura do proletariado e o avanço das forças produtivas industriais levaria à crescente hostilidade dos kulaks sem contudo elevar a consciência do pequeno campesinato, abalando a estabilidade do regime revolucionário. 
Trotsky anteviu como solução para esse impasse a extensão do processo revolucionário para além das fronteiras russas. O caráter internacional da Revolução forneceria o sustentáculo político para a ditadura do proletariado através da solidariedade da classe operária mundial.

Bogdánov, a partir das palavres de Sterni, parece concordar com Trotsky em seu primeiro postulado: não é possível contar com o campesinato para fornecer o suporte necessário para a Revolução socialista a não ser enquanto tática transitória. A vitória da Revolução depende de seu caráter internacional. O Capital, enquanto sujeito universal, precisa ser enfrentado por uma resposta universal, daí o sentido de permanência na teoria trotskista. No entanto, a heterodoxia de Bogdánov somente o leva até esse momento. Enquanto a Teoria da Revolução Permanente de Trotsky rompe com o economicismo e torna a revolução uma tarefa fundamentalmente política do proletariado, Bogdánov nega mesmo o caráter político do processo de internacionalização como tática central. Esse processo encontra sua barreira na condição fragmentada da experiência que induz à alienação dos espaços enquanto fronteiras nacionais. Para Bogdánov a condição de totalidade não deve ser restrita à tática política da revolução internacional, pois nela está contida a categoria de nacionalidade. Bogdánov propõe a totalidade partir da categoria de classe, uma vez que a condição categorial do proletariado enquanto proprietário da força de trabalho que produz valor ao mesmo tempo em que é mercadoria é o fundamento ontológico do Capital, a força motriz de seu processo de ampliação e sua condição universal. Somente na universalidade da experiência do proletariado é possível contrapor a natureza universal do Capital. Somente por meio de sua visão de mundo é possível romper os limites nacionais e a própria internacionalidade política da revolução.

Netti, por sua vez, toma a palavra para se opor aos planos de aniquilação defendidos por Sterni. Através de Netti, Bogdánov apresenta os fundamentos centrais do empiriomonismo. Bogdánov defende por meio das palavras de sua personagem que o caminho terrano para o socialismo não é melhor ou pior que aquele realizado pelos marcianos, mas fundamentalmente diferente:

"Por centenas de milhões de anos o maravilhoso planeta Terra viveu sua própria vida particular, uma vida diferente de outros planetas. 
E agora a consciência começa a se desenvolver a partir de suas forças espontâneas. Progredindo através de uma amarga e difícil luta dos estágios mais baixos até os mais desenvolvidos, essa consciência finalmente assumiu formas humanas parecidas com as nossas. Mas essas formas não são idênticas a nós: a história de um ambiente natural diferente e de uma luta diferente está refletida neles. Elas ocultam um jogo diferente de forças espontâneas, outras contradições, outras possibilidades de desenvolvimento. (...) os terráqueos não são como nós. Eles e sua civilização não são simplesmente mais primitivos ou fracos - eles são diferentes." (Bogdanov, 1984 [1908] :116-117)

Netti introduz seus argumentos a partir do monismo empiriocriticista de Mach, que serviu de fundamento para o marxismo fenomenológico de Bogdánov. A natureza parte de formas mais simples em direção à formas cada vez mais sofisticadas em uma grande continuidade. A evolução é o mecanismo regulatório desse processo, selecionando os elementos mais adaptados a contribuírem para o desenvolvimento do sistema total. Netti combate o darwinismo social proposto por Sterni - a subjugação do mais fraco pelo mais forte - reorientando o debate para a qualidade da diferença. Os argumentos de Sterni partem da necessidade. Netti parte da alteridade:

\begin{abstract}
"Nos reinos vegetal e animal milhões de espécies competem violentamente e rapidamente superam umas as outras, contribuindo através de suas vidas e mortes para o desenvolvimento de novas espécies mais sintéticas, mais perfeitas e harmônicas. O mesmo é verdade para os humanos. (...) Seu caminho é espinhoso, cheio de inversões e viradas. A própria severidade e violência do conflito inspirou nos combatentes uma energia e paixão, um espírito de heroísmo e auto-sacrifício que eram totalmente ausentes na luta mais moderada e menos trágica de nossos ancestrais. Nesse aspecto a vida dos povos da Terras é mais evoluída que a nossa, mesmo que nossa cultura seja mais antiga e tenha atingido um nivel mais alto." (Bogdanov, 1984 [1908]:118)
\end{abstract}

Netti termina seu discurso salientando que a filosofia terrestre é mais sofisticada que a filosofia marciana na verve de sua revolução, graças à imensa variedade de visões de mundo possibilitadas pela riqueza de elementos produzidos na diversidade terrana. Nesse momento Bogdánov abandona quaisquer subterfúgios para defender seu projeto de futuro: 
"Todos os sistemas filosóficos são, é claro, manifestações de uma cognição imperfeita e fragmentada e refletem um nível deficiente de desenvolvimento científico. Eles representam tentativas de prover uma descrição uniforme do Ser preenchendo as lacunas existentes na experiência científica com especulações. Eventualmente, portanto, a filosofia será eliminada na Terra assim como foi eliminada entre nós pelo Monismo da Ciência" (Bogdanov, 1984 [1908] :119)

Netti termina sua fala defendendo que os marcianos - caso necessário reduzam sua taxa de natalidade até que o problema seja resolvido. Para ela seria um crime "drenar esse tempestuoso porém belo oceano de vida" que é a raça humana. A união futura dos mundos valerá esse sacrifício uma vez que a unidade da vida é o objetivo último do socialismo, terrano ou marciano. Sua moção é aprovada. A Terra está salva do imperialismo marciano.

Após esse episódio a consciência de Leonid finalmente se rompe. As aparições dão lugar a uma negritude de sensações. Leonid se dirige ao escritório de Sterni e o assassina com um objeto pesado, através de um golpe na têmpora. Ao se entregar, Leonid se sente culpado por trair a raça humana e aguarda por uma execução. No entanto, entre estados de perda de consciência, Leonid desperta onde a estória se inicia: na clínica psiquiátrica do Dr. Werner. Esse é o fim de sua jornada em Marte.

Os capítulos finais apresentam as ponderações finais de Leonid sobre sua experiência. Convalescendo na clínica do Dr. Werner, Leonid testemunha o fracasso da Revolução de 1905 e passar a duvidar da veracidade de sua experiência, tomando-a como uma crise de delírio. O protagonista externa aqui as próprias considerações de Bogdánov acerca da experiência de 1905.

"A Revolução acabou arrastada por uma período frustrantemente longo. A classe trabalhadora foi a primeira a atacar e sua rápida ofensiva resultou em significantes vitórias iniciais. No entanto, diante da falta de apoio das massas campesinas no momento crítico, acabou sofrendo uma derrota retumbante nas mãos das forças reacionárias unificadas." (Bogdanov, 1984 [1908] : 130)

Além da falta de apoio da classe camponesa, Leonid também aponta para a traição da pequena burguesia que, ao lado dos grandes proprietários, escolheu abandonar os proletários revoltosos em torno de um programa de negociações com o governo: 
"Disfarçado na forma de uma comédia parlamentar, essas tentativas se chocavam repetidamente contra a atitude descompromissada dos proprietários feudais reacionários. Parlamentos-marionetes eram convocados e brutalmente dissolvidos, um após o outro." (Bogdanov, 1984 [1908]: 131)

Por fim, Leonid culpa a própria Intelligentsia radical:

“(...) muitos acabaram exaustos e começaram mesmo a se desesperar. A auto-proclamada Intelligentsia radical, cuja participação na revolução se limitou na maior parte a demonstrações de simpatia, traiu a causa quase que até seu último membro" (Bogdanov, 1984 [1908]:131)

Através de Leonid, Bogdánov engrossa as fileiras daqueles que identificaram nesses setores as fraturas do movimento revoltoso de 1905. Trotski, por exemplo, identifica entre os inimigos da Revolução a grande burguesia, o inchado aparato autocrático e uma massa politicamente indeterminada de pequeno-burgueses, intelectuais liberais e jornalistas radicais (Trotski, 1908 : 159). Victor Serge ressaltou a própria ação de aliciamento da autocracia a partir da reforma agrária de Stolypin que vinculou os interesses dos kulaks à manutenção do regime, solapando o apoio do campesinato à revolução já em ocaso (Serge, 1993:45). Lenin, em sua primeira aparição pública de massas realizada em maio de 1906, responsabilizou os kadets por terem cooperado com o regime autocrático na identificação dos líderes revoltosos que culminou na prisão do Comitê Central do soviete de São Petersburgo. Entre os presos estavam Martov, Trotsky e Bogdánov, esse último o representante bolchevique no CC (Krausz, 2015:53).

Mas se Leonid aponta para os kulaks, a pequena-burguesia e os intelectuais como os grandes culpados pelo fracasso da Revolução de 1905, esse não deixa de refletir sobre o próprio fracasso. Leonid se recorda de uma conversa que travou com Menni a respeito de sua escolha como embaixador; Leonid questiona por que não fora escolhido um embaixador entre os grandes líderes do Partido dos Trabalhadores:

"Entre os representantes do partido você também conheceu pessoas mais fortes e talentosas que eu. Você conheceu o líder que chamamos 
carinhosamene de 'Velho da Montanha', você conheceu nosso camarada, o poeta..."

"Sim, e eu os observei de perto. Mas o 'Velho da Montanha' é um homem exclusivamente de luta e revolução. Nossa ordem não o agradaria em nada. Ele é um homem de aço e homens de aço não são flexíveis. Eles também têm uma forte carga de conservadorismo. Já o poeta, ele não resistiria fisicamente. Ele passou por muitas coisas em suas aventuras através de todos os estratos sociais de seu mundo e teria dificuldade em sobreviver a mais uma transição".

"Mas deixe-me lembrá-lo de Mirsky, o filósofo. Em sua profissão ele está acostumado a fazer avançar, comparar e reconciliar os mais disparados pontos de vistas".

"Verdade, mas deixe-me lembrá-lo que ele é, acima de tudo, um homem do pensamento abstrato. Ele dificilmente teria o vigor espiritual necessário para trazer suas emoções e vontade de forma a resistir às suas experiências de uma nova vida" ${ }^{9}$ (Bogdanov, 1984 [1908] : 133-134)

A impressão que nos dá a partir dessa passagem é a sensação de intransponibilidade entre as culturas terrana e marciana. Anteriormente, sabemos por meio de Netti que diversos países contaram com agentes marcianos que buscaram sem qualquer sucesso em suas populações um candidato ideal para a missão de embaixador (Bogdanov, 1984 [1908] :42). Menni parece procurar por um indivíduo dotado de uma estrutura físico-psicológica bastante específica: boa saúde física, flexibilidade, capacidade para trabalho intelectual, sem laços pessoais na Terra e que sofra do mínimo possível de individualismo (Bogdanov, 1984 [1908] : 43). Questionado por que não escolhera um proletário para levar a cabo tal missão, Menni responde:

“(...) trabalhadores geralmente são carentes daquilo que considero um importante pré-requisito: uma educação ampla e sólida baseada no melhor que sua cultura atingiu" (Bogdanov, 1984 [1908] :135)

Leonid conclui que Menni também errou. Um trabalhador cuja visão de mundo tenha se iniciado nas relações de camaradagem do trabalho fabril teria se adaptado melhor ao caráter coletivista da sociedade marciana. Para ele,

9 O uso de pseudônimos faz um pobre trabalho em esconder a identidade desses líderes. O "Velho da Montanha", um homem de ação e luta, de personalidade férrea e irredutível é claramente Lenin; o poeta a quem Leonid se refere é Maxim Gorkii, colaborador e amigo de Bogdánov; e Mirsky, um homem de pensamento abstrato que reconcilia disparates é Plekhánov. 
seu fracasso derivou da tentativa em se integrar a uma sociedade cujos laços sociais eram profundamente orgânicos, cujas relações sociais eram marcadas por um coletivismo de perfeito equilíbrio. Sua psique individualista não encontrou elementos no sistema social marciano nos quais pudesse se apoiar. Leonid terminou estranhado, o que resultou em seus surtos psicóticos.

"Eu não posso deixar de imaginar se tais contradições seriam mais fortes e agudas no caso de um homem como eu, um intelectual revolucionário que, em nove-décimos de seu tempo tenha trabalhado sozinho ou em uma relação desigual com seus camaradas trabalhadores, para quem ele tem sido um professor e líder. Em outras palavras foi meu isolamento do coletivo que deve ser culpabilizado. Talvez tais contradições tivessem se provado menos agudas para um homem que gastou nove décimos de sua vida laboral em um ambiente mais bruto e primitivo, porém pervadido de um espírito de camaradagem. Um ambiente no qual a igualdade fosse real ainda que limitada. (...) Menni deveria renovar sua busca em outro estrato." (Bogdanov, 1984 [1908]:135)

Na parte final do romance, Leonid se alia com Vladimir, um jovem revolucionário oriundo das classes trabalhadoras e passa a tutelá-lo em estudos clássicos e científicos ao mesmo tempo em que retorna para a luta revolucionária. Ambos fogem da clínica e se envolvem com as lutas populares nas ruas de São Petersburgo. Após uma ação suicida, Leonid é carregado de volta para a clínica do Dr. Werner, gravemente ferido por fragmentos de granada.

O que nos pode dizer a jornada de Leonid, sua queda em desgraça e seu consequente fracasso? Em primeiro lugar, o papel central que Bogdánov dedica a aspectos psicológicos, a uma estrutura mental que ele vê não somente como resultado do triunfo do socialismo, mas como seu pré-requisito. Sujeito a elementos radicalmente coletivistas, Leonid, um socialista por educação marcado pelo individualismo gestado por uma visão de mundo burguesa, não conseguiu estabelecer ligações tektológicas com o ambiente que o cercava e por conta disso acabou alijado dos complexos ideológicos que deveriam organizar sua psique. Sua experiência individual impediu que ele se subsumisse à experiência coletiva marciana. Leonid terminou estranhado, incapaz de se realizar enquanto ser genérico através da práxis produtiva - do trabalho. 
Leonid acabou por se objetificar, a se ver como uma peça de qualidade inferior no grande maquinário, razão pela qual deixou de ter prazer nos estudos e na atividade laboral (Bogdanov, 1984 [1908] : 96). Leonid se torna, em meio à produção baseada na causalidade laboral, um operário terrano controlado por um complexo de elementos ideológicos ossificados por sua visão de mundo burguesa e incompatíveis com a experiência coletivista marciana.

Alguns pesquisadores, em parte devido a uma leitura estreita da obra de Bogdánov, enxergaram no final anticlimático de "Estrela Vermelha" um suposto pessimismo de Bogdánov em relação ao futuro da revolução, expressa na obra pelo esforço em denotar diferenças irreconciliáveis entre o desenvolvimento histórico das sociedades marciana e terráquea. Greenfield (2006:633) denota que Leonid é o herói de seu tempo, porém um herói trágico, diagnosticado a partir de sua experiência com a doença do individualismo; Adams (1989:9) salienta que a partir de desenvolvimentos históricos tão distintos seria impossível, para Bogdánov, que o socialismo da terra fosse se desenvolver na forma harmoniosa do socialismo marciano; Gerould (1987:272) conclui a partir de sua leitura que, por serem menos agressivos, os marcianos são mais adaptados ao socialismo. Todas essas leituras nos faz acreditar que a mensagem de Bogdánov era uma mensagem negativa, de impossibilidade.

Tais leituras partem de uma visão reduzida da obra, de seu autor e do contexto no qual ela é produzida. "Estrela Vermelha" não é tão somente uma obra despretensiosa de FC. Decerto ela é - enquanto forma - uma obra de FC. Mas essa é apenas uma de suas dimensões. Em primeiro lugar devemos levar em consideração o fundamento filosófico em que Bogdánov assentou sua produção. A incapacidade de Leonid em se adequar não se deveu a uma incompatibilidade irredutível entre as duas sociedades, mas ao fato de que ele, inserido no sistema marciano, torna-se um elemento regressivo, i.e. desorganizador. Ainda que todo sistema tenha elementos dessa natureza, os mecanismos reguladores buscarão compensar seus efeitos em direção a uma condição de equilíbrio. Isso fica patente no episódio em que trabalhadores marcianos acabam constantemente compensando os erros de Leonid. Usar a inadequação de Leonid como impossibilidade de contato entre os dois planetas é ignorar que sistemas não podem ser comparados a partir de seus elementos 
isolados, retirados da totalidade. Além disso, como destaca Jensen (1982), ao condicionar as particularidades do processo revolucionário a elementos culturais e subjetivos, Bogdánov abre espaço para inúmeras possibilidades de transição, muitos socialismos possíveis. O que distingue tais caminhos são as formas particulares de metabólise entre os sistemas sociais e seus ambientes, os diferentes conflitos sociais que emergem da organização social do trabalho e suas correspondentes estruturas ideológicas. No entanto não podemos confundir essa diversidade de atividades como uma característica pluralística da interpretação bogdanoviana. Os caminhos são muitos, mas o ponto de chegada é unívoco: o comunismo. Bogdánov enquanto positivista aplica em seu sistema diversos conceitos trazidos das ciências naturais, entre eles o conceito de evolução convergente. O processo evolutivo sempre encontra uma forma adaptativa ótima para uma dada condição ambiental. Os organismos mais evoluídos de um determinado ambiente compartilham características similares. É por essa razão que os marcianos são tão semelhantes aos homens, mesmo evoluindo em um outro planeta. Bogdánov tomou emprestado da biologia uma concepção sistêmica do real e transportou esse modelo para buscar explicar o desenvolvimento das sociedades. A despeito do trajeto evolutivo, Bogdánov considera o comunismo como a forma mais sofisticada e adaptável de organização da prática social. Quanto mais complexo e sofisticado - mais rico organizativamente - é um sistema social, mais ele se parece com o comunismo marciano (Jensen, $1982: 16$ ).

A descrição feita por Sterni é fundamental para compreender no documento a marca do pensamento social de Bogdánov. Se tomada única e exclusivamente como mero processo político, a revolução será fatalmente distorcida pelos elementos ideológicos típicos da velha sociedade burguesa, como o patriotismo, o individualismo e o autoritarismo. Tais elementos encontramse no cerne da Intelligentsia cuja filosofia é a estrutura consciente que reflete a realidade fragmentada. Leonid tem sua consciência erodida porque, enquanto intelectual burguês, ele é incapaz de extrapolar sua experiência individual, seus valores e estruturas ideológicas. Na sociedade burguesa os processos são determinados por necessidades abstratas, que emergem das relações de classe e acabam por se autonomizar, ganhando controle dos próprios processos que 
as gestam. Isso produz um mundo caótico, desorganizado, que fragmenta a revolução de acordo com as fronteiras nacionais. Para Bogdánov a resposta para esse impasse está em Vladimir, o jovem revolucionário tutelado por Leonid. Bogdánov enxerga nas relações coletivistas da classe trabalhadora um denominador comum que ultrapassa as fronteiras nacionais, com potencial para superar a visão fragmentada da Intelligentsia e unificar as dimensões fraturadas do pensamento e da práxis em um grande monismo.

Bogdánov já não acreditava que deveria ser o papel da Intelligentsia atuar como vanguarda da classe trabalhadora. A partir das lições que retirou do fracasso da revolução de 1905, Bogdánov entendeu que a Intelligentsia - e em especial os marxistas ortodoxos - encontravam-se eivados de elementos ideológicos burgueses como o individualismo e o autoritarismo. Para ele, intelectuais burgueses que realmente refletissem a visão-de-mundo operária eram tão raros quanto "corvos brancos". Ao mesmo tempo em que tais intelectuais, socialistas por educação, colaboravam com os operários através de suas habilidades organizativas, Bogdánov também entendia que, ao fazê-lo, a Intelligentsia reforçava as relações autoritárias de dominação já presentes na vida laboral dos trabalhadores. Sochor argumenta que há na obra de Bogdánov uma posição cada vez mais crítica à noção de partido por perceber que é essência desse conceito a divisão social do trabalho entre organizadores e executores, cabendo aos intelectuais o primeiro papel, reforçando assim a passividade da classe trabalhadora em relação ao partido (Sochor, 1988:37). Esse argumento é bastante plausível a partir de dois dados originados de fontes diferentes: por um lado, em "Estrela Vermelha" não apenas inexiste o Estado como também qualquer forma de organização semelhante a partidos; e por outro sua própria biografia: Bogdánov foi o único membro da facção vperedista que nunca retornou às fileiras bolcheviques, mesmo tendo sido convidado a retornar diversas vezes por Kamenev e Bukharin (White, $2018: 244)$.

Os argumentos de Marot expressos anteriormente (p. 196) acabam por fazer água frente a uma leitura mais criteriosa de "Estrela Vermelha". Bogdánov não reserva à Intelligentisa um papel de vanguarda da classe operária. Ao contrário, Bogdánov enxergava nessa proposição política um risco aos es- 
forços revolucionários por reforçar os elementos autoritários, individualísticos e fragmentários da sociedade burguesa. Isso não significa, porém, que Bogdánov descarte totalmente a participação da Intelligentsia, como Biggart faz parecer. Como vimos anteriormente é justamente a recusa do espontaneísmo das massas que fez com que Bogdánov se aliasse a Lenin na formação da facção bolchevique. Bogdánov, mesmo enquanto membro do CC do Soviete de São Petersburgo, tinha poucas ilusões a respeito do nível de consciência das classes trabalhadoras, como pode ser atestado pela carta de Kollontai a Gorki, escrita em 1905 (Porter, 1980 : 322). Além disso, se tomarmos como pressuposto que Bogdánov tratou sua utopia com seriedade, é nítido o seu sentimento de simpatia pela Intelligentsia técnica. Afinal, "Estrela Vermelha" é uma obra sobre intelectuais e engenheiros. Para Bogdánov, o caráter contraditório de classe gozado pela Intelligentsia, em um contexto de crise sistêmica condicionado pelo equilíbrio de forças na luta entre as classes sociais, pode possibilitar que a mesma ascenda provisoriamente enquanto classe dominante, apartando-se do espaço intermediário que recebe nas relações de produção, subvertendo assim sua posição subordinada aos capitalistas e sua posição organizativa entre os proletários (Biggart, 1990 : 269). Essa condição provisória permitiria que a Intelligentsia atuasse pedagogicamente com o objetivo de estimular o desenvolvimento de elementos ideológicos socialistas no interior da classe trabalhadora, servindo como catalisador para a formulação da visão de mundo daquela classe. Essa atuação objetivaria enriquecer a experiência coletiva dos trabalhadores com as conquistas científicas e artísticas mais avançadas produzidas pelo sistema capitalista. Para Bogdánov, através da justaposição desses elementos com experiência laboral coletivista dos trabalhadores, surgiria uma nova ciência, uma nova arte, que organizariam por sua vez a experiência fragmentada em um sistema monístico coeso e harmonioso. Somente com o desenvolvimento da visão de mundo do labor, baseada por sua vez nos elementos ideológicos de uma arte e ciência proletárias, seria possível a superação do caráter fetichista da sociedade burguesa e, consequentemente, a vitória permanente do socialismo.

Bogdánov acreditava que tal visão de mundo se constituiria conforme o avanço das forças produtivas esgarçassem ainda mais o hiato entre as formas 
organizativas burguesas e as relações cooperativas de labor, características da maquinofatura. No entanto, esse processo poderia ser acelerado através da Intelligentsia com vistas a prover a classe trabalhadora de uma "disciplina intelectual formal", de forma a instilar nela o surgimento de futuras lideranças revolucionárias (Bogdánov, 1909, apud Marot 1990 : 253). Caberiam então aos intelectuais as tarefas de completar a educação dos trabalhadores para o socialismo e ajudá-los a expressar sua visão de mundo sem no entanto distorcer seu conteúdo por conta de sua formação ideológica burguesa. Walicki (1990 : 302) frisou ser essa concepção de educação proposta por Bogdánov caracteristicamente maiêutica, ao contrário do caráter tutelar defendido por Marot. A imposição de um processo de doutrinação na forma tutelar seria profundamente alienígena à estrutura de pensamento de Bogdánov, por reproduzir relações autoritárias entre intelectuais e trabalhadores.

Aos intelectuais socialistas, limitados pelos elementos ideológicos característicos da visão de mundo burguesa, caberia a formação de uma nova Intelligentsia saída das fileiras da classe trabalhadora e armada com as mais avançadas técnicas culturais. Somente esses, "socialistas por nascimento", cuja visão de mundo é constituída diretamente pela práxis do labor, seriam capazes de liderar o processo revolucionário. Leonid é um herói do presente; Vladimir, o jovem lutador de rua, é o herói do futuro no qual Bogdánov deposita a esperança da revolução. Essa formulação já expressa em "Estrela Vermelha" em 1908 demonstra um ponto pivotal no pensamento de Bogdánov, que o afastará nos anos subsequentes das tarefas políticas em direção às tarefas educacional e científica. A partir de sua abordagem culturalista da revolução, Bogdánov organizou a dissidência vperedista que, entre 1909 e 1911, fundou nas cidades de Capri e Bolonha duas universidades proletárias, com o objetivo de formar lideranças socialistas entre trabalhadores emigrados russos. Posteriormente já durante a Guerra Civil em 1919 os vperedistas acabariam por criar, a partir da proposta bogdanoviana, o Proletkult.

No pensamento de Bogdánov, o conhecimento é o intercurso psíquico e a transferência de todas as formas de experiências entre os membros da totalidade social. Por essa razão a cultura em suas muitas formas tem uma estrutura interna, uma função organizacional implícita. Qualquer fruto da 
cultura tem a sua própria arquitetura e representa a totalidade subdividida das partes, realizando uma variedade de funções intercomplementares. Bogdánov defendia que a cultura exerce um papel real e prático na sociedade, uma tarefa organizacional. Mais do que tratar a cultura como um epifenômeno, algo que se encontra implicado no uso do termo superestrutura, ele sugeriu uma concepção estruturalista de cultura. A cultura formava um tipo de infraestrutura na sociedade com seu próprio papel definitivo. A despeito de sua aparência puramente idealista e intangível, a ideologia funciona como o esqueleto das relações humanas.

O progresso tecnológico é sempre o ponto de partida para Alexander Bogdánov, pois é ele que engendra o processo de fragmentação da sociedade em classes e grupos sociais:

"a base das divisões sociais reside no progresso tecnológico, na produção, mas seu momento formativo é a ideologia, ou várias ideologias. O fundamento de uma sociedade de classe é a ausência mútua de compreensão entre grupos sociais: suas experiências de vida, suas organizações, suas aspirações, suas percepções de mundo se tornam totalmente diferentes." (Bogdánov, 1914, apud Sochor 1988:71)

A Ideologia tem tanto um papel desorganizativo quando organizativo. Mas uma sociedade que sofre com a luta de classes pode ser mantida unida por determinados valores comuns. No capitalismo, a cultura do individualismo serve como denominador comum entre seus membros. Os trabalhadores também derivam de uma ideologia pequeno-burguesa. O avanço tecnológico traz mudanças no papel do trabalhador dentro da produção. Tal mudança facilita uma ruptura com as ideologias dominantes. O momento de crítica generalizada leva os capitalistas a adotarem formas ideológicas cada vez mais reacionárias, combinando nacionalismo, clericalismo e militarismo.

Para Bogdánov, o surgimento de novas formas cognitivas, adequadas às novas formas de produção, se baseariam nas necessidades revolucionárias e na solidariedade de classe. Bogdánov adiciona um critério cultural para se pensar o conceito marxista de classe, problematizando com isso a compreensão do processo de formação e dissolução das classes. Para o proletariado ascender 
ao poder ele deve adquirir todas as funções úteis de direção do sistema de produção antes do momento da revolução. Sem esse aprendizado, a eliminação da classe proprietária poderia levar a um retrocesso através da destruição da alta cultura e a transição para uma cultura menos sofisticada (Sochor, 1988: 76). Bogdánov dedica assim um importante papel à ideologia, menos como um catalisador e mais como um obstáculo. No momento em que as ideologias se tornam obstáculos cada vez maiores ao progresso, sua ruptura e destruição se tornam uma necessidade organizacional. Sem a destruição dos antigos complexos ideológicos que estruturam a sociedade de classes, o socialismo fatalmente se desviaria, tornando a análise de Sterni uma profecia auto-realizável.

A expulsão de Bogdánov a partir da reunião do Comitê Central do jornal Proletarii é fato histórico bastante conhecido. No entanto, a partir da leitura de "Estrela Vermelha" é possível propôr um novo olhar para esse momento e que passara desapercebido pela historiografia até aqui analisada: esse não fora um rompimento unilateral, que partira exclusivamente de Lenin. Bogdánov já havia rompido, ao menos intelectualmente, com o bolchevismo. As razões de sua expulsão não são meramente factuais (Jensen, 1978:24), econômicas (Glenny, 1970:212) ou políticas (Marot, 1990 :243), mas fundamentalmente epistemológicas. Enquanto Lenin reivindicava como fundamento tático da revolução a hegemonia política do partido na forma da vanguarda, Bogdánov reivindicava a hegemonia ideológica a partir de uma nova cultura. Não podemos responder se tais diferenças eram contornáveis. Sabemos somente que, por força do contexto ja suficientemente descrito pela historiografia relevante, acabaram por se tornar posições irreconciliáveis.

O fim da filosofia e sua substituição por uma Ciência Universal Organizacional é o ponto de chegada de Bogdánov. Tal ponto só seria possível a partir da unificação das experiências individual e coletiva em um sistema monístico que levaria à dissolução de todas as dicotomias e fragmentações do real, compondo por fim um grande coletivo orgânico, um único sistema. Nesse grande coletivo mesmo a individualidade acaba por se subsumir ao todo. Nesse sentido, o coletivismo orgânico de Bogdánov se assemelha ao coletivo maquinal de Alexei Gastev. No entanto, quaisquer semelhanças terminam 
aí. Enquanto para Gastev a crescente automatização das forças produtivas leva ao desaparecimento do trabalho criativo e qualificado, restando apenas o operário biomecânico, para Bogdánov o avanço técnico dessas mesmas forças acaba por eliminar o trabalho alienado e as divisões social e técnica do trabalho, restando tão somente o organizador do processo de produção, o mestre da maquinofatura. Partindo do socialismo científico, o socialismo vislumbrado por Bogdánov é um socialismo da ciência, em que cada ato de produção é um ato científico. Não há operários em Marte, pois não há divisão entre trabalho manual e intelectual. Há tão somente cientistas e engenheiros unidos em uma grande ciência organizacional, a depositária definitiva de todo o conhecimento, o fundamento máximo do socialismo empiriomonista. 


\section{5 \\ Considerações Finais}

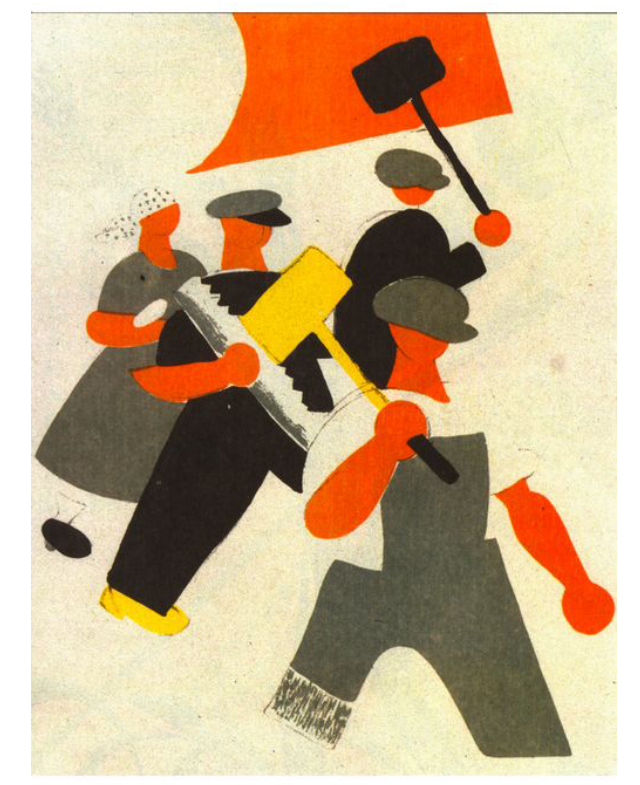

"For the bright day when man will grope blindly no more But will see how his task must be done;

If he chooses the path that leads straight to the core He and life can then fuse into one.

When space, yes, and time have been conquered by man And the elements and death are but words, Our two races will merge into one mighty clan Of builders of brilliant new worlds."

(Bogdanov, 1984 [1908] : 238) 
Este é o momento em que buscaremos fazer um balanço das dificuldades apresentadas e possíveis contribuições realizadas por este trabalho a partir das problemáticas expostas inicialmente. Entre os obstáculos encontrados no decorrer desta pesquisa, cita-se em primeiro lugar a dificuldade de acesso a fontes primárias. Mesmo após a recuperação parcial de sua obra e o crescente interesse demonstrado por pesquisadores de diversos campos do saber até a presente data, é relativamente pequena a quantidade de materiais disponíveis, tendo em vista a volumosa obra que Bogdánov produziu em sua vida infelizmente abreviada por um experimento científico fracassado. Excetuando a publicação de "Estrela Vermelha" a partir da tradução de David Rowley em 1984, a maior parte das obras traduzidas datam dessa última década, como "Philosophy of Living Experience" (2016) e o primeiro volume de "Tektology" (2017). Somente em 2018 foi publicada uma biografia intelectual de Bogdánov por James White e que serviu como principal obra de referência para a seção biográfica presente na Introdução. É seguro dizer que, a despeito do crescente interesse que traz, ainda há muito o que ser feito em relação à divulgação de sua obra. Por essa razão acabamos por nos concentrar na análise de uma ampla bibliografia secundária, bastante fragmentada em decorrência do caráter polímata de Bogdánov que gerou o interesse de pesquisadores das mais diversas áreas. Este foi um "bom" problema, pois permitiu, a despeito do esforço adicional de levantamento bibliográfico, compor um retrato mais completo de Bogdánov e do amplo escopo de sua obra.

Uma segunda dificuldade derivou da primeira acima apresentada: a barreira linguística. A ausência de fontes traduzidas para as línguas ocidentais acabou por direcionar nossos trabalhos em direção aos materiais disponíveis na língua russa. Aliado ao esforço de produção deste trabalho, adicionou-se também a tarefa de dominar - ao menos instrumentalmente - a língua russa de forma a expandir as possibilidades de análise. Este esforço foi profundamente útil. Foi possível por exemplo perceber que nosso documento primário a tradução em inglês de "Estrela Vermelha" - continha lamentavelmente liberdades inaceitáveis de tradução, que alteravam mesmo o sentido da narrativa. Dado o tempo determinado para a elaboração deste trabalho, não 
foi possível simplesmente substituir a tradução em inglês por uma tradução inédita da obra. Por outro lado, seria inaceitável utilizar como fonte primária um documento visivelmente alterado. Optamos por conta disso cotejar os trechos selecionados para esta análise entre a tradução e a obra original, de forma a garantir a idoneidade do material documental sem prejuízo dos prazos e escopo desta Dissertação. (A tradução de "Estrela Vermelha" a partir do original desponta como um projeto futuro.)

Um terceiro problema se refere à forma de abordagem temporal utilizada na exposição. No decorrer da análise, fomos tomados em diversos momentos por dúvidas em relação à abordagem pretendida: deveria nossa análise se restringir a uma abordagem sincrônica, recortando - e isolando - do movimento histórico de sua elaboração os diversos diálogos entre o texto e seu contexto de forma a analisá-los individualmente? Ou deveríamos renunciar ao rigor de uma metodologia sincrônica em prol de uma maior flexibilidade de análise a partir de uma aproximação diacrônica, mais apta a promover uma visão panorâmica da tessitura da trama narrativa em sua relação com o autor e os diversos momentos, aproximando-se metodologicamente da crítica literária? As especificidades do documento primário utilizado - uma obra literária de FC utópica - acabaram por permitir um trajeto metodológico que, se não rompeu com tais limites, nos estimulou a tentar trilhar por entre eles. Partindo da categorização elaborada por Fredric Jameson que define a literatura utópica enquanto "desligamento" e "recuo" do mundo empírico e histórico de forma a fazer valer a superação da crítica do mundo por meio de uma forma universal (Jameson, 2005:23), a análise de "Estrela Vermelha" nos permitiu não apenas reconstituir uma versão particular do desenvolvimento histórico da Rússia e de seus tumultos pelos olhos de um de seus intelectuais mais prolíficos e originais, como também possibilitou pela natureza total de seu intento utópico reconstituir uma história do futuro desse passado a partir dos diversos elementos de seu pensamento já presentes na obra em estado embrionário e que no futuro adquiririam formas maduras e independentes. "Estrela Vermelha" nos serviu como uma janela que recorta um panorama do mundo restrito por seus limites, mas da qual é possível extrapolar imageticamente sua continuidade para além de suas fronteiras. 
O Capítulo 2 deste trabalho cumpriu uma função essencialmente didática, razão pela qual buscamos nos concentrar em seu aspecto descritivo. Buscamos, dentro das limitações desta pesquisa, apresentar a "Filosofia da Vivência" de Aleksandr Bogdánov a partir da leitura direta de sua obra, bem como descrever o contexto histórico no qual essas ideias se desenvolveram. Objetivamos com isso apresentar os fundamentos que orientaram suas reflexões nos mais importantes projetos aos quais se dedicou no decorrer de sua vida e que, de certa forma, acabaram por determinar o caráter abrangente de seus trabalhos. Além disso, julgamos necessário familiarizar o leitor com o empiriomonismo bogdanoviano e seus fundamentos, já que sem uma compreensão inicial de suas bases epistêmicas, a leitura de "Estrela Vermelha" e sua relação com o contexto histórico acabam seriamente prejudicadas. Tomamos por conseguinte esse capítulo como um prolegômeno para os capítulos restantes.

No Capítulo 3 decidimos por apresentar um mapa narrativo do espaço de "Estrela Vermelha" enquanto expressão da concretude das relações sociais. Esse processo deu continuidade a um levantamento bibliográfico e consequente descrição dos debates intelectuais que consideramos centrais para formação da Intelligentsia radical russa. Nesse capítulo tratamos do desenvolvimento da Intelligentsia rasnotchiets a partir das reformas alexandrinas de 1861 que levaram à dissolução das relações servis em solo russo bem como às reformas administrativas e educacionais que acabaram por estreitar as laços entre intelectuais e o narod. Acabamos por tratar também do desenvolvimento do narodtchestvo e dos debates acerca do processo de industrialização da Rússia a partir das reformas de Witte entre importantes intelectuais narodistas e a nascente social-democracia russa, já nos anos 1880. A apresentação desse debate foi fundamental para compreender o desenvolvimento de um posicionamento historicamente ambíguo (moral, político, social) que a Intelligentsia russa demonstrava acerca da relação dialética entre os diferentes espaços do Capital (cidade e campo, urbano e rural) e das diversas expressões que tais relações receberam na arte, na literatura e no pensamento político. Também foi a partir desse contexto histórico-intelectual que nos foi possível traçar elementos desse momento específico na leitura de "Estrela Vermelha". Fun- 
damentados na crítica de Lenin ao processo de mercantilização das relações de propriedade e produção pelas quais passara a obshchina, pudemos analisar como Bogdánov operou a superação das relações de alienação expressas pela divisão entre campo e cidade a partir da descrição de um espaço desalienado, cuja organicidade conquistada pelo controle consciente tornava obsoletas tais divisões, reflexos daquilo que denominou de grande fetichismo. A partir da questão espacial - e artística - objetivamos por fim demonstrar o papel central que a teoria do fetichismo de Marx exercera em seu pensamento e obra, um dado histórico no mínimo interessante dado o peso secundário desse fundamento marxiano nos debates da social-democracia de então.

O quarto e último capítulo compreende a maior parte do trabalho e amplia o enfoque diacrônico realizado nos capítulos anteriores referente aos debates intelectuais constitutivos da Intelligentsia russa pré-revolucionária, estendendo-o até os primeiros anos posteriores à Revolução de 1917. Analisamos primeiramente as críticas de Plekhanov e Lenin às bases epistemológicas do machianismo russo, expressas respectivamente em "Materialismus Militans: Reply to Mr. Bogdanov" e "Materialismo e Empiriocriticismo". Esse procedimento nos possibilitou inscrever tal debate, de forma geral, no contexto das disputas políticas extrafaccionais que ocorriam no interior do POSDR; e, de forma específica, analisar sob sua luz a crise do Centro Bolchevique de 1909, que colocou Bogdánov e Lenin em campos opostos. Esse debate resultou tanto na formação da "partinost" por meio da reafirmação da ortodoxia quanto no surgimento do grupo "Vpered", cujas fileiras abrigaram por poucos anos o núcleo intelectual antileninista dentro do bolchevismo. Objetivamos com isso ressaltar o caráter fundamentalmente organizacional do cisma estabelecido entre Lenin e Bogdánov, frequentemente ignorado em favor de diferenças políticas, táticas e programáticas. Decerto que tais diferenças encontram-se presentes e são relevantes. No entanto, defendemos que essas derivam de concepções radicalmente diferentes da classe, cultura e hegemonia. Enquanto Lenin priorizou a luta política como elemento-chave do esforço revolucionário, Bogdánov compreendia que tal esforço deveria ser acompanhado de esforços para a constituição de uma Cultura Operária. O caráter culturalista que Bogdánov dedica à Revolução fica mais claro a 
partir do debate que empreendeu com Alexei Gastev já em 1919 a respeito da Organização Científica do Trabalho (NOT). A partir da exposição desse debate foi possível apresentar a força que as pulsões utópicas do coletivismo e da maquinofatura exerciam sobre o imaginário desses intelectuais e que já se encontravam expressas na condição desalienada das relações de trabalho descritas por Bogdánov em "Estrela Vermelha" uma década antes.

$\mathrm{Na}$ última parte do quarto capítulo intentamos apresentar os fundamentos daquela que Bogdánov considerou sua obra máxima: a Tektologia. Balizado em sua teoria do conhecimento empiriomonista, Bogdánov buscou desenvolver aquilo que considerava postulados básicos de uma teoria geral de sistemas cuja função seria prover fundamentos organizacionais que permitissem a transposição de modelos científicos entre as diferentes áreas do saber, unificando-as metacientificamente em uma única ciência, cujo lançamento extinguiria por fim o caráter fragmentário do saber científico burguês. Foi a partir desses postulados tektológicos que Bogdánov, já em 1921, ao lado de Varga e Kristman, apresentou um modelo de planificação econômica baseado em tabelas de input-output cujo cálculo econômico se determinaria por meio de sua teoria do equilíbrio dinâmico. Sua teoria visava a identificar rapidamente os gargalos produtivos e solucioná-los a partir da crescente automação dos meios de produção, em total desacordo com a implementação de técnicas tayloristas, dependentes da superexploração do proletariado e fortalecimento da alienação do trabalho vivo. A análise do sistema produtivo marciano nos mostrou que os germes de tais ideias já se encontravam presentes uma década antes em seu esforço imaginativo expresso em "Estrela Vermelha".

Esse trabalho se finalizou com a análise da concepção de classe social presente na obra, concepção essa que, de certa forma, fornece a síntese de sua vasta e polimática obra. É a partir do sofrimento psicológico do protagonista que Bogdánov expressa sua desconfiança da Intelligentsia enquanto vanguarda do proletariado, uma vez que essa era somente socialista "por educação" e carregava consigo os elementos ideológicos (autoritarismo e individualismo) da visão de mundo burguesa. Somente por meio da formação de uma nova geração de intelectuais saída das fileiras da classe trabalhadora é que seria possível a constituição de uma nova visão de mundo, baseada em relações 
produtivas cooperativas e que expressaria a unidade da atividade social, transcendendo através disso a condição alienada. A formação do grande coletivo e o triunfo do socialismo exigiam como pré-requisito a construção da cultura proletária que superasse as dicotomias produzidas pelo sistema capitalista; tais dicotomias fragmentavam o espaço, a filosofia, as ciências e a própria consciência, impedindo que os trabalhadores desenvolvessem sua consciência de classe, a seu ver, sua principal arma política. Esse deveria ser o papel dos intelectuais socialistas de seu tempo.

O uso de "Estrela Vermelha" como documento histórico se mostrou, sob a luz de seu contexto histórico de produção e das fontes secundárias, muito mais fecundo do que prevíamos no início dessa pesquisa. Em parte acreditamos que isso se deu por decorrência de suas especificidades: o momento histórico pivotal em que foi produzida, que raramente é pronunciado pela bibliografia relevante, e que marcou não somente uma virada nas reflexões de seu autor a partir de sua interpretação do passado, como na própria social-democracia russa; o uso das características canônicas do gênero utópico para ressaltar por um lado sua interpretação crítica da história então recente da Rússia - desde a desintegração da obshchina, passando pelo processo revolucionário de 1905, até a ilusão parlamentar das Dumas - e por outro produzir imageticamente um futuro desse passado a partir da superação da condição alienada por meio de postulados já presentes em seu pensamento, ainda que de forma embrionária, e que se expressariam com maturidade em seus projetos futuros.

Em nossa abordagem metodológica, dada a riqueza do documento, decidimos por trabalhar através de uma perspectiva cruzada. Utilizamos "Estrela Vermelha" como um ponto de convergência entre os diferentes objetos históricos que compõem o contexto de sua realização e que se encontram espalhados diacronicamente entre o passado e o futuro da obra. Tais objetos foram justapostos, observados em suas intersecções sincrônicas, para compreender de que forma se relacionavam dialeticamente com texto/contexto. Dessa forma foi possível identificar as particularidades que dialogam com o contexto histórico sem removê-los de sua totalidade dialética, expressa no desenvolvimento das ideias de Bogdánov localizadas em tempos posteriores. O uso da história cruzada possibilitou evitar anacronismos grosseiros, uma vez que 
tais elementos, vistos de forma justaposta, evidenciavam muitas vezes as incongruências de formas não acabadas, mas já expressas.

Essa abordagem também traz alguns problemas. Ao nos utilizarmos da hermenêutica marxista proposta por Fredric Jameson, um fundamento teórico próprio da crítica literária marxista, acabamos por nos comprometer em tentar resgatar a totalidade silenciosa soterrada na especificidade do texto. Esse é um posicionamento que entendemos superar as barreiras do método e que por isso torna-se político. Abandonamos por conta disso a forma monográfica em favor de uma exposição metadisciplinar, incorporando autores dos mais diversos campos do saber: críticos literários, sociólogos, filósofos, geógrafos, historiadores, economistas e urbanistas. Sabemos que esse movimento gera atritos com a abordagem metodológica dominante na historiografia contemporânea, fortemente influenciada pela virada culturalista, que privilegia o particular e específico sobre total e universal, a fragmentação em detrimento da unicidade, o fato sobre o provável. No entanto, estamos convictos de que nosso objeto não poderia ser tratado de outra maneira, dada a natureza multifacetada de seu autor e a ampla gama de seus interesses expressos no texto. A obra de Bogdánov não recebera até o presente momento uma análise que objetivasse demonstrar a totalidade de seu pensamento justamente pelo caráter monográfico dos estudos produzidos a partir dela e sua compreensão sofreu por conta disso. Além disso, o estudo de uma obra utópica a partir de uma perspectiva historiográfica é também, no limite, um ato de posição: o provável é um fato concreto, ainda que não realizado. É o provável que move o desejo utópico em direção ao futuro e reafirmar a possibilidade de estudo do provável não deixa de ser uma forma de resistência à destruição do tempo promovida pelo Capital, nosso próprio objeto de estudo, que reduz nossa experiência da temporalidade a um eterno presente, condicionado por seu circuito de reprodução.

Sob esse prisma não é difícil compreender o movimento da ciência histórica contemporânea em reduzir cada vez mais o escopo de delimitação do objeto a um momento mínimo circunscrito pela especificidade. Mais do que nunca devemos resgatar as totalidades utópicas, tanto enquanto projetos como desejos. O provável dá voz ao passado, aquilo que não foi mas que poderia 
ser, e projeta no futuro o desejo da utopia. Walter Benjamin expressou essa rebelião da forma mais elegante: "Ela é o salto de tigre para o passado. Acontece que ele se dá numa arena onde quem comanda é a classe dominante. O mesmo salto, mas sob o céu livre da história, é o salto dialético da revolução, como Marx o concebeu" (Benjamin, 1987:230). Não devemos enquanto historiadores nos acautelar de contar uma história do possível, do imaginável e do desejoso - da utopia - contanto que nos ancoremos na concretude do real. Para isso nos serve o materialismo dialético de Marx.

A partir dessa perspectiva, "Estrela Vermelha" nos contou muitas histórias. Ela nos contou uma história político-econômica da Rússia entre a passagem dos séculos XIX e XX; ela nos contou uma história dos debates intelectuais constitutivos da Intelligentsia e suas contradições; ela nos contou uma história da apropriação e transformação do pensamento marxiano pela radicalidade russa; ela nos contou uma história da recepção do positivismo por esses radicais. Todas essas histórias encontram-se cruzadas e são transformadas pelas lentes de um intelectual original e promíscuo que viveu seus diversos desenrolares, participou ativamente de suas tramas e cujo ponto-de-vista só agora vem sendo reconstituído. "Estrela Vermelha" é uma obra original e única em diversos aspectos. Ela não é somente a obra inaugural da FC Soviética, ainda que também o seja. Ela não é somente a primeira obra de FC de natureza marxista, um intento no mínimo inusitado para a época. Sua originalidade também se estende à história da literatura utópica através de seu caráter teleológico aberto, em que o conflito não é removido, mas transposto para a relação do homem com a natureza. A História continua seu movimento, na forma de uma catástrofe ambiental incontornável com que se depara a totalidade marciana. Essa dimensão aberta e trágica da utopia serve como um negativo para a tragédia da luta de classes na Terra e das difíceis decisões que cabem às gerações de ambos os planetas. Essa condição teleológica que se encontra em aberto é um rompimento com a natureza totalizante das utopias modernas e se inscreve naquilo que os estudos utópicos designam como "utopia crítica", i.e. o uso da narrativa utópica a partir da "critique", com o objetivo de elaborar um pensamento de oposição que desacoberta tanto o gênero quanto o contexto histórico. "Estrela Vermelha" é menos um 
projeto e mais um sonho (Moylan, $2014: 10$ ).

Esperamos por fim que este trabalho tenha atingido ao menos parcialmente dois objetivos a serem descritos. Em primeiro lugar, demonstrar a riqueza e diversidade dos debates empreendidos pela Intelligentsia russa em seu período pré-revolucionário, caracterizada por um tatear constante em busca de ideias e programas que dessem conta da especificidades da Rússia e de seu povo. Esse tatear tem uma história própria, eivada de contradições e que permaneceu por décadas silenciada a partir de uma historiografia mais interessada em reconstituir uma imagem instrumentalizada dessa Intelligentsia do que apresentar suas múltiplas expressões. Em segundo lugar, fornecer um panorama inédito em amplitude do pensamento político e econômico de Aleksandr Bogdánov, dando conta de suas contribuições em diversos campos da atividade intelectual revolucionária russa. Mais do que profícuo, Bogdánov foi um intelectual acima de tudo promíscuo, cuja obra buscou amalgamar a teoria marxiana ao que entendia haver de mais moderno na filosofia da ciência de seu tempo: o energitismo de Ostwald; a epigenética de Haeckel; o empiriocriticismo de Mach e Avenarius; a teoria da evolução de Darwin; o monismo de Dietzgen. Como resultado acabou por produzir uma forma única de marxismo fenomenológico, empiricamente monístico e baseado em um sofisticado modelo funcionalista. Foi a partir desse caminho único, heterodoxo em seu limite, que Bogdánov, ao buscar compreender o papel dos sistemas ideológicos na formação da consciência e na resiliência das relações autoritárias burguesas, acabou por inferir aspectos centrais da Teoria da Alienação de Marx, que só seriam publicadas quatro anos após sua morte nos "Manuscritos Econômico-Filosóficos" em 1932. A partir da Teoria do Fetichismo de Marx, Bogdánov elaborou sua critique sobre o caráter fragmentário da consciência e dos riscos inerentes a uma Intelligentsia carregada de individualismo, tornando-a linha condutora de sua vasta obra e o fundamento de sua teoria do conhecimento.

A despeito de seu afastamento das atividades revolucionárias, Bogdánov manteve um status de proeminência entre a intelectualidade russa durante toda a sua vida e influenciou importantes nomes do socialismo russo nos anos formativos do Estado Soviético, como Bukharin, Gastev, Stepanov, 
Prokrovski e Riazanov. No entanto, em parte pelos longos anos de proscrição decorrentes de sua disputa com Lenin, em parte pela censura de seus trabalhos a partir do regime estalinista, sua obra não deixou descendentes, caindo em esquecimento por muitas décadas. É seguro concluir que Bogdánov, a partir dos ricos debates do começo do século XX, antecipara questões importantes e que seriam desenvolvidas pelo marxismo europeu nas décadas seguintes: a interpenetração das relações mercantis na psique; a determinação de uma consciência coletiva potencial a partir da posição de classe na produção; a ascensão de grupos sociais marcados por posições de classe indeterminadas; a necessidade de formação de intelectuais que expressem organicamente o sujeito coletivo da classe trabalhadora; a superação da alienação a partir da reconciliação entre as experiências objetiva e subjetiva.

A luta contra a autocracia russa aliada a uma centenária tradição radical produziu na passagem entre os séculos XIX e XX uma geração intelectualmente fecunda e diversa, e Bogdánov foi talvez o intelectual que mais fielmente representou esse momento. Bogdánov transitou entre o narodismo e a social-democracia; entre o marxismo e o positivismo; entre a política e a cultura; entre a ciência e a filosofia; entre a arte e a revolução. Esse caráter transicional é talvez a força e a fraqueza de sua obra: força pela originalidade das respostas que elaborou para as questões de seu tempo e fraqueza pela inadequação dessas ideias em um tempo que clamava por ação política. Estudar "Estrela Vermelha" foi como "navegar no tempestuoso e belo oceano" de suas ideias, sabendo que esse esforço cobriu apenas uma fração de seu trabalho, cuja extensão é digna de posteriores estudos. Se esta Dissertação serviu para lançar luzes sobre um rico e tumultuoso contexto histórico, bem como sobre um importante e original intelectual cuja história pode - e deve ser reabilitada, consideraremos este um trabalho bem sucedido. 


\section{Referências Bibliográficas}

AdAms, Mark B. "'Red Star": Another Look at Aleksandr Bogdanov." Slavic Review, vol. 48(1), 1-15, 1989.

BAILES, Kendall E. "Alexei Gastev and the Soviet Controversy over'Taylorism, 1918-24." Soviet Studies, vol. 29(3), 373-394, 1977.

Ballestrem, Karl G. "Lenin and Bogdanov." Studies in Soviet Tought, vol. 9(4), 283-310, 1969.

BAnks, Eric C. Ernst Mach's World Elements: A Study in Natural Philosophy. Dordrecht: Springer Science, 2003.

Baron, Samuel H. "Plekhanov and the Origins of Russian Socialism." The Russian Review, vol. 13(1), 38-51, 1954.

Batchelor, Peter. "The Origin of the Garden City Concept of Urban Form." Journal of the Society of Architectural Historians, vol. 28(3), 184-200, 1969.

Belfer, E. "Zemlya vs. Volya. From Narodnichestvo to Marxism." Soviet Studies, vol. 30(3), 297-312, 1978.

Belykh, A. A. "A Note on the Origins of Input-Output Analisys and the Contribution os the Early Soviet Economists: Chayanov, Bogdanov and Kritsman." Soviet Studies, vol. 41(3), 426-429, 1989.

. "A. A. Bogdanov's Theory of Equilibrium and the Economic Discussions of the 1920's." Soviet Studies, vol. 42(3), 571-582, 1990. 
Benjamin, Walter. Magia e Técnica, arte e política: Ensaios sobre literatura e história da cultura, vol. I. São Paulo: Editora Brasiliense, 1987.

Beveridge, Albert Jeremiah. The Russian Advance. Whitefish: Kessinger Publishing, 2007.

Biggart, John. "Bukharin and the Origins of the 'Proletarian Culture' Debate." Soviet Studies, vol. 39(2), 229-246, 1987.

- "Alexander Bogdanov and the Theory of a "New Class"." The Russian Review, vol. 49(3), 265-282, 1990.

Bogdanov, Aleksandr. "Mezhdu Tchelovekom i Machinuiu: A Sisteme Taylora." In: Priboi, 5, p. 5, 1913.

URL https://ruslit.traumlibrary.net/book/ bogdanov-mezhdu-chel/bogdanov-mezhdu-chel.html\#work002

- "Programma Kul'turi." In: Voprosi Sotcializma, 1918 a. URL https://ruslit.traumlibrary.net/book/ bogdanov-voprosy-socialisma/bogdanov-voprosy-socialisma.html\# work008003
—. "Sotcializm v Nastoiashchem." In: Voprosy Sotsializma, 1918 b. URL https://ruslit.traumlibrary.net/book/ bogdanov-voprosy-socialisma/bogdanov-voprosy-socialisma.html\# work004

- "The Criticism of Proletarian Art." Labour Monthly, vol. V(6), 344-356, 1923.

- A Short Course of Economic Science. London: Communist Party of Great Britain, 1932.

- Makers of the Russian Revolution: Biographies of Bolshevik Leaders. Sydney: Allen \& Unwin, 1974.

—. Essays in Tektology. Seaside: Intersystems Publicatons, 1980. 
. Red Star: A Utopia. Bloomington: Indiana University Press, 1984 [1908].

. The Philosophy of Living Experience. Leiden: Brill, 2016 [1913].

Boll, Michael. "From Empiriocriticism to Empiriomonism: the Marxist Phenomenology of Aleksandr Bogdanov." The Slavonic and East European Review, vol. 59(1), 41-58, 1981.

Branco, Sonia. "Real'naia Kritika e a Construção de uma Nova Sociedade." Anais do XI Congresso Internacional da ABRALIC, 2008.

- Figurações Críticas e Literárias na Rússia Oitocentista. Tese de Doutorado. Rio de Janeiro: UFRJ, 2014.

Brandist, Craig. "The cultural and linguistic dimensions of hegemony: aspects of Gramsci's debt to early Soviet cultural policy." Journal of Romance Studies, vol. 12(3), 24-43, 2012.

- The Dimensions of Hegemony: Language, Culture and Politics in Revolutionary Russia. Leiden: Brill, 2015.

Briusov, Valeri. Republic of the Southern Cross, 1919.

URL https://archive.org/details/cu31924026696124/page/n8

Buber, Martin. O Socialismo Utópico. São Paulo: Ed. Perspectiva, 2007.

Bukharin, Nikolai. "In memory of A.A. Bogdanov." Speech at the Civil Funeral Ceremony, 1928.

URL https://www.academia.edu/1505700/Nikolai_Bukharin_In_ memory_of_A.A._Bogdanov_translation_

CARR, Edward Halletr. Studies in Revolution. New York: The Universal Library, 1964.

Chartien, Roger. A História Cultural: entre práticas e representações. Miraflores: Difusão Editorial, 2002. 
- A história ou a leitura do tempo. São Paulo: Autêntica Editora, 2009.

Cockshott, Paul \& Cottrell, Allin. Towards a New Socialism. Nottingham: Russell Press, 1993.

Coggiola, Osvaldo. "Antecedentes da Revolução Russa." Ms., 2017.

URL https://www.academia.edu/33894722/ANTECEDENTES_DA_ REVOLU\%C3\%87\%C3\%830_NA_R\%C3\%9ASSIA

Confino, Michael. Russia before the "Radiant Future": Essays in Modern History, Culture, and Society. New York: Berghahn Books, 2011.

DAnIELs, Robert Vicent. The Conscience of Revolution: Communist Opposition in Soviet Russia. Boulder: Westview Press, 1960.

de Certeau, Michel. The Writing of History. New York: Columbia University Press, 1988.

DereK, Offord. The Russian Revolution Movement in the 1880s. Cambridge: Cambridge University Press, 1986.

Eagleton, Terry. Marxismo e Crítica Literária. Porto: Edições Afrontamento, 1976.

—. Why Marx was Right. New Haven: Yale University Press, 2011.

EAton, Henry. "Marx and the Russians." Journal of the History of Ideas, vol. 41(1), 102-123, 1980.

Engels, Friedrich. A Dialética da Natureza. São Paulo: Ed. Paz e Terra, 1979 .

FritzPatrick, Sheila. The Russian Revolution. Oxford: Oxford University Press, 1994.

Gare, Arran. "Aleksandr Bogdanov and Systems Theory." Democracy \& Nature, vol. 6(3), 341-359, $2000 a$. 
"Aleksandr Bogdanov's History, Sociology and Philosophy of Science." Studies in History of Philosophy and Science, vol. 31(2), 231-248, 2000 b.

Gastev, Aleksei. "O tendentsiyakh proletarskoi kultury." In: Proletarskaya Kul'tura, 10. Moscow: Proletarii, 1919.

Gerould, Daniel. "Alexander Bogdanov, Founder of Soviet Science Fiction." Science Fiction Studies, vol. 14(2), 271-274, 1987.

Glenny, Michael. "Leonid Krasin: The Years before 1917. An Outline." Soviet Studies, vol. 22(2), 192-221, 1970.

Gloveli, Georgii D. \& BigGart, John. " "Socialism of Science" versus "Socialism of Feelings": Bogdanov and Lunacharskii." Studies in Soviet Thought, vol. 42(1), 29-55, 1991.

Gomes, Rosa Rosa. Rosa Luxemburgo: Crise e Revolução. Cotia: Ateliê Editorial, 2018.

Gorelik, George. "Bogdanov's Tektology: its basic concepts and relevance to modern generalizing sciences." Human Systems Management, vol. 1(4), 327-337, 1980.

. "Bogdanov's Tektology: Its Nature, Development and Influence." Studies in Soviet Thought, vol. 26(1), 39-57, 1983.

Grahan, Loren R. Science in Russia and the Soviet Union: A Short History. Cambridge: Cambridge University Press, 1993.

Greenfield, Douglas. "Revenants and revolutionaries: Body and society in Bogdanov's Martian novels." The Slavic and East European Journal, vol. 50(4), 621-634, 2006.

Grespan, Jorge. O Negativo do Capital. São Paulo: Expressão Popular, 2012.

Harvey, David. A Produção Capitalista do Espaço. São Paulo: Annablume Editora, 2001. 
—. Para Entender o Capital. São Paulo: Ed. Boitempo, 2002.

—. A Loucura da Razão Econômica. São Paulo: Ed. Boitempo, 2011.

Hellebust, Rolf. "Gastev and the metallization of the revolutionary body." Slavic Review, vol. 56(3), 500-518, 1997.

Hobsbawm, Eric. A Era dos Impérios. São Paulo: Ed. Paz e Terra, 1988.

Hobsbawm, Eric J. A Era do Capital 1848-1875. São Paulo: Ed. Paz e Terra, 2012.

Ilyenkov, Evald V. The Ideal in the Human Activity. Pacifica: Marxists Internet Archive Publications, 2009.

Jameson, Fredric. Postmodernism, or, The Cultural Logic of Late Capitalism. New York: Verso, 1991.

. Archaeologies of the Future: The Desire Called Utopia and Other Science Fictions. New York: Verso, 2005.

- The Ideologies of Theory. New York: Verso, 2008.

Jensen, K. M. Beyond Marx and Mach: Aleksandr Bogdanov's Philosophy of Living Experience. Dordrecht: D. Reidel Publishing Company, 1978.

- "Red Star: Bogdanov Builds a Utopia." Studies in Soviet Thought, vol. 23(1), 1-34, 1982.

JorAvsky, David. Soviet Marxism and Natural Science: 1917-1932. New York: Routlegdge Library Editions, 1961.

Kelly, Aileen M. "Red Queen or White Knight? The Ambivalences of Bogdanov." The Russian Review, vol. 49(3), 305-315, 1990.

Krader, Lawrence. "Evolução, Revolução e Estado: Marx e o Pensamento Etnológico." In: História do Marxismo: O Marxismo no Tempo de Marx, vol. I. Rio de Janeiro: Editora Paz e Terra, 1979. 
Krausz, Tamás. Reconstructing Lenin. An Intellectual Biography. New York: Monthly Review Press, 2015.

Krementsov, Nikolai. A Martian Stranded on Earth: Alexander Bogdanov, Blood Transfusions and Proletarian Science. Chicago: The University of Chicago Press, 2011.

Laue, Theodor H. Von. "The Fate of Capitalism in Russia: The Narodnik Version." American Slavic and East European Review, vol. 13(1), 3-22, 1954.

LAzAgna, Angela. "Lenin e o "Taylorismo Soviético": uma abordagem crítica." Ponto e Vírgula, vol. 21, 36-53, 2017.

Lefebvre, Henri. The Urban Revolution. Minneapolis: University of Minnesota Press, 2003.

Lefebvre, Henry. The Sociology of Marx. New York: Columbia University Press, 1982.

Lenin, Vladimir Ilich. What the "Friends of the People" Are and How They Fight the Social-Democrats, 1893.

URL https://www.marxists.org/archive/lenin/works/1894/ friends/index.htm

. "The immediate tasks of the Soviet Government." In: Lenin Collected Works. Moscow: Progress Publishers, $1972 a$.

- "The Taylor System: Man's Enslavement by the Machine." In: Lenin Collected Works, vol. 20. Moscow: Progress Publishers, $1972 b$.

- "A "Scientific" System of Sweating." In: Lenin Collected Works, vol. 18. Moscow: Progress Publishers, 1975.

- "Those who would liquidate us." In: Lenin: Collected Works, vol. 17. Moscow: Progress Publishers, 1977.

. Materialismo e Empiriocriticismo. Lisboa: Editorial Avante, $1982 a$. 
- O Desenvolvimento do Capitalismo na Rússia: O processo de formação do mercado interno para a grande indústria. São Paulo: Editora Abril, $1982 b$.

- O Estado e a Revolução. Campinas: Editora Navegando, 2011.

Löwy, Michael. The Politics of Combined and Uneven Development: The Theory of Permanent Revolution. New York: Verso, 1981.

- The Theory of Revolution in the Young Marx. Chicago: Haymarket Books, 2003.

LunACHARSKI, Anatol. "Novyi russkii chelovek." In: Isvestia, 23, p. 2, 1923.

Luxemburgo, Rosa. A Acumulação do Capital: Estudo sobre a Interpretação Econômica do Imperialismo. Rio de Janeiro: Zahar Editores, 1970.

Mally, Lynn. Culture of the Future: The Proletkult Movement in Revolutionary Russia. Berkeley: University of California Press, 1990.

Mansueto, Anthony. "From Dialectic to Organization: Bogdanov's Contribution to Social Theory." Studies in East European Thought, vol. 48(1), 37-61, 1996.

MArot, John Eric. "Bogdanov, Vpered and the Role of the Intellectual in the Worker's Movement." The Russian Review, vol. 49(3), 241-264, 1990.

- "Marxism, Science, Materialism: Toward a Deeper Appreciation of the 1908-1909 Philosophical Debate in Russian Social Democracy." Studies in East European Thought, vol. 45(3), 147-167, 1993.

MARX, Karl. "A letter to the editorial board of 'Otechestvennye Zapiski'." In: Shanin, Teodor (Ed.), Late Marx and the Russian Road: Marx and 'the Peripheries of Capitalism', p. 33. New York: Monthly Review Press, 1983.

A Miséria da Filosofia. São Paulo: Global Editora, 1985.

Manuscritos Econômicos Filosóficos. São Paulo: Ed. Boitempo, 2004. 
—. O Capital, vol. II. São Paulo: Ed. Boitempo, 2010.

- A Guerra Civil na França. São Paulo: Ed. Boitempo, 2011a.

—. O 18 Brumário de Luís Bonaparte. São Paulo: Ed. Boitempo, $2011 b$.

—. Crítica ao Programa de Gotha. São Paulo: Ed. Boitempo, 2012.

—. O Capital, vol. I. São Paulo: Ed. Boitempo, 2013.

—. O Capital, vol. III. São Paulo: Ed. Boitempo, 2017.

Marx, Karl \& Engels, Friedrich. O Manifesto Comunista. São Paulo: Ed. Boitempo, 1998.

—. A Ideologia Alemã. São Paulo: Ed. Boitempo, 2007.

MCClelland, James. "Bolshevik Approaches to Higher Education, 19171921." Slavic Review, vol. 30(4), 818-831, 1971.

McNally, David. Against the Market: Political Economy, Market Socialism and the Marxist Critique. New York: Verso, 1993.

MészÁros, István. A Teoria da Alienação em Marx. São Paulo: Ed. Boitempo, 2016.

Miéville, China \& Bould, Mark. Red Planets: Marxism and Science Fiction. Middletown: Wesleyan University Press, 2009.

Mikhailov, Nicolai. "Non-Party Worker's Organizations in St. Petersburg and the Provinces Before and During the First Russian Revolution." In: Pirani, Donald Fitzer; Wendy Z. Goldman; Gis Kessler; Simon (Ed.), A Dream Deferred: New Studies in Russian and Soviet Labour History, pp. 30-45. Bern: Peter Lang, 2008.

Mikhailovski, Nicolai. "Polnoe Sobranie Sochinenii." In: Shanin, Teodor (Ed.), Late Marx and the Russian Road: Marx and the Peripheries of Capitalism, pp. 33-41. New York: Monthly Review Press, 1983[1876]. 
Moylan, Tom. Demand the Impossible: Science Fiction and the Utopian Imagination. Bern: Peter Lang, 2014.

NaArden, Bruno. Socialist Europe and Revolutionary Russia: Perception and Prejudice 1848-1923. Cambridge: Cambridge University Press, 1992.

Odoievski, Vladimir. "From the year 4338: Letters from St. Petersburg." In: Levitski, Alexander (Ed.), Words Apart: An Anthology of Russian Fantasy and Science Fiction, pp. 153-199. New York: Overlook Publishing, 2007.

Pannekoek, Anton. Lenin as Philosopher. Milwaukee: Marquette University Press, 2003.

Plekhanov, Georgui. Socialism and Political Struggle, 1883.

URL https://www.marxists.org/archive/plekhanov/1883/ struggle/

. Materialismus Militans: Reply to Mr. Bogdanov. Moscow: Progress Publishers, 1976 [1908].

URL https://www.marxists.org/archive/plekhanov/1907/ materialismus-militans.htm

Pokrovski, M. N. Causas Econômicas da Revoluc̃cão Russa. Rio de Janeiro: Ed. Calvino, 1944.

Porter, Cathy. Alexandra Kollontai: a biography. London: Virago Press, 1980.

Radishchev, Alexander. "A Journey from St. Petersburg to Moscow." In: RiBA, Thomas (Ed.), Readings in Russian Civilization: Imperial Russia 1700-1917, pp. 183-207. Chicago: University of Chicago Press, 1964.

Remington, Thomas F. "Varga and the Foundation of Soviet Planning." Soviet Studies, vol. 34(4), 585-600, 1982.

Robinson, Kim Stanley. Red Mars. New York: Bantam Books, 1993. 
RogGer, Hans. "Amerikanizm and the Economic Development of Russia." Comparative Studies and History, vol. 23(3), 382-420, 1981.

Rosenberg, Arthur. A History of Bolshevism: from Marx to the Five Year's Plan. Garden City: Anchor Books, 1967.

Rowley, David. "Introduction." In: Red Star: A Utopia. Bloomington: Indiana University Press, 1984.

Rowley, David G. "Bogdanov and Lenin: Epistemology and Revolution." Studies in East European Thought, vol. 48(1), 1-19, 1996.

Serge, Victor. O Ano I da Revolução Russa. São Paulo: Editora Ensaio, 1993.

Shanin, Teodor. "The People's Will: basic documents and writings." In: Chanin, Teodor (Ed.), Late Marx and the Russian Road: Marx and 'the Peripheries of Capitalism'. New York: Monthly Review Press, 1983.

Slonim, Marc. Russian theater: from the Empire to the Soviets. Cleveland: The World Publishing Company, 1961.

Sochor, Zenovia. Revolution and Culture: The Bogdanov-Lenin Controverse. Ithaca: Cornell University Press, 1988.

SpIegel, Gabrielle M. Practicing History: New Directions in Historical Writing after the Linguistic Turn. New York: Routledge Group, 2005.

Stableford, Brian. "The origins of Science Fiction." In: The Cambridge Companion to Science Fiction, pp. 13-31. Cambridge: Cambridge University Press, 2006.

Sternin, A. Sobre a obra de V. I. Lenin "Materialismo e Empiriocriticismo". Porto: Edições Progresso, 1988.

Stites, Richard. "Utopias of Time, Space and Life in the Russian Revolution." Revue des Études Slaves, 1984. 
- Revolutionary Dreams: Utopian Vision and Experimental Life in the Russian Revolution. Oxford: Oxford University Press, 1989.

Suvin, Darko. "The Utopian Tradition of Russian Science Fiction." The Modern Language Review, 1971.

- Metamorphoses of Science Fiction: On the Poetics and History of a Literary Genre. New Haven: Yale University Press, 1979.

TChernichevski, Nicolai. What is to be done? Ithaca: Cornell University Press, 2013.

Traub, Rainer. "Lenin and Taylor: the fate of "scientific" management in the (early) Soviet Union." Telos, (37), 1978.

Trotski, Leon. 1905. Marxist.org, 1908.

URL https://www.marxists.org/archive/trotsky/1907/1905/ch02. htm

—. Literatura e Revolução. Rio de Janeiro: Zahar Editores, 1969.

- Minha Vida: Ensaio Autobiográfico. Rio de Janeiro: Ed. Paz e Terra, 1978.

Venturi, Franco. Roots of Revolution: A History of the Populist and Socialist Movements in Nineteenth Century Russia. London: Willian Clowes and Sons Ltd., 1960.

Veyne, Paul. Como se escreve a história: Foucault revoluciona a história. Brasília: Ed. UnB, 1998.

WALICKI, Andrzej S. "Alexander Bogdanov and the Problem of the Socialist Intelligentsia." The Russian Review, vol. 49(3), 293-304, 1990.

WARK, McKenzie. Molecular Red: Theory for the Antropocene. New York: Verso, 2015.

Wells, H. G. A Modern Utopia. Auckland: The Floating Press, 2009 [1905]. 
Werner, Michael \& Zimmermann, Bénédicte. "Pensar a história cruzada: entre empiria e reflexividade." Textos de História, vol. 11(1/2), 89-127, 2003.

White, James D. Red Hamlet: The life and Ideas of Alexander Bogdanov. London: Brill, 2018.

Williams, Raymond. Marxism and Literature. Oxford: Oxford University Press, 1977.

Williams, Robert C. "Collective Immortality: The Syndicalist Origins of Proletarian Culture, 1905-1910." Slavic Review, vol. 39(3), 389-402, 1980.

Wood, Alan. As origens da Revolução Russa: de 1861 a 191\%. São Paulo: Editora Ática, 1987.

Wren, Daniel \& Bedeian, Arthur G. "The Taylorization of Lenin: rethoric or reality?" International Journal of Social Economics, vol. 31(3), 287-299, 2004.

Yassour, Avraham. "Lenin and Bogdanov: Protagonists in the "Bolshevik Center"." Studies in Soviet Thought, vol. 22(1), 1-32, 1981.

. "The Empiriomonist Critique of Dialectical Materialism: Bogdanov, Plekhanov, Lenin." Studies in Soviet Thought, vol. 26(1), 21-38, 1983.

Zaitsev, Cyril \& Pares, Bernard. "The Russian Agrarian Revolution." The Slavonic and East European Review, vol. 9(27), 547-566, 1931.

Zamiatin, Eugeni. Nós. São Paulo: Ed. Aleph, 2017. 